РОССИЙСКАЯ АКАДЕМИЯ НАУК

ИНСТИТУТ АРХЕОЛОГИИ

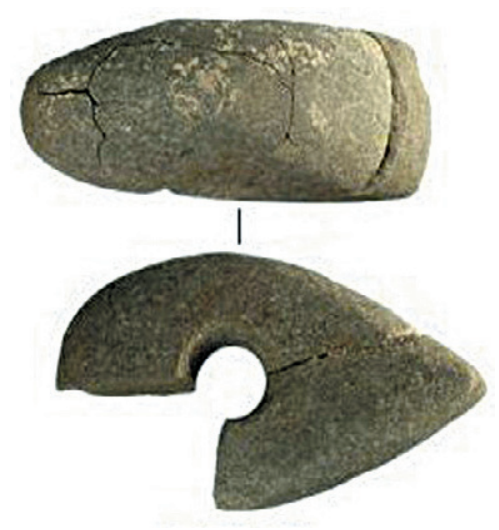


RUSSIAN ACADEMY OF SCIENCES

INSTITUTE OF ARCHAEOLOGY

\author{
S. N. Korenewskiy
}

Settlement Tuzla-15 of The Early Bronze Age

On The Taman peninsula

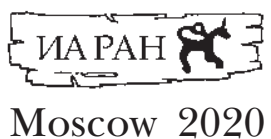


РОССИЙСКАЯ АКАДЕМИЯ НАУК

ИНСТИТУТ АРХЕОЛОГИИ

С.Н. Кореневский

Поселение раннего бронзового века Тузла-15

на Тамани

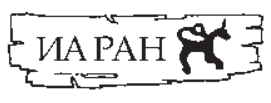

Москва 2020 
УДК 902/903

ББК 63.4

К66

\section{Утверждено к печати Ученым советом ИА РАН}

Работа выполнена в Отделе археологии Бронзового века ИА РАН

Научный редактор

кандидат исторических наук И. Н. Сударев

Рецензенты:

кандидат исторических наук В. И. Мельник

кандидат исторических наук А. Ю. Скаков

Кореневский С.Н. Поселение раннего бронзового века Тузла-15 на Тамани. М. Изд. ИА РАН. 200 с.: ил.

ISBN 978-5-94375-297-1

Монография посвящена публикации поселения майкопско-новосвободненской общности Тузла-15, расположенного на Таманском полуострове. Работы носили характер разведки культурного слоя памятника в 2012-2015 гг. В их результате были найдены остатки 4-х построек конца IV-начала III тыс до н. э. и одно захоронение теленка. В книге приводятся данные о древнем климате исследуемой эпохи, проведен анализ костей моллюсков и животных, используемых в пищу, фитолитный анализ останов органики, сделаны радиоуглеродные определения возраста открытых жилищ-полуземлянок. В конце исследования дан анализ бытовых построек майкопско-новосвободненской общности Предкавказья и сделаны соответствующие выводы о связанных с ними культах и верованиях изучаемой эпохи. Работа рассчитана на археологов, краеведов, этнологов, всех, кто интересуется древней историей Таманского полуострова и восточного Причерноморья.

The monograph is devoted to the publication of the settlements of the Maikop-Novosvobodnaya community Tuzla-15, located on the Taman Peninsula. The works were of the nature of exploration of the cultural layer of the monument in 2012-2015. As a result, the remains of 4 buildings of the end of IV-beginning of III mil BC and one burial of a calf were found. The book provides data on the ancient climate of the investigated era, the analysis of the bones of mollusks and animals used in food, conducted a phytolith analysis of organic matterials, made radiocarbon age determination of open dwellings-semi-dugouts. The analysis of household structures of the Maikop-novosobodnenskaia community of the fore-Caucasus and the relevant conclusions about the related cults and beliefs of the period under review at the end of the study. The work is designed for archaeologists, local historians, ethnologists, anyone interested in the ancient history of the Taman Peninsula and the Eastern Black sea coast.

УДК 902/903

ББК 63.4

DOI: 10.25681/IARAS.2020.978-5-94375-297-1

(c) С. Н. Кореневский, 2020

(C) Федеральное государственное бюджетное учреждение науки Институт археологии Российской академии наук, 2020 


\section{ОГЛАВЛЕНИЕ}

ВВЕДЕНИЕ. ОТ АВТОРА

ГЛАВА 1 .

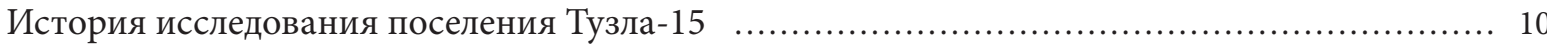

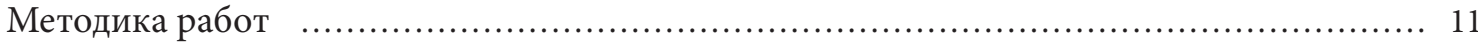

ГЛАВА 2.

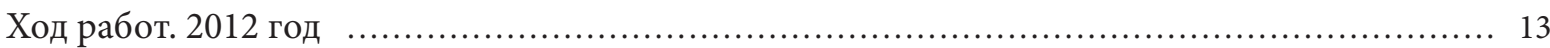

ГЛАВА 3.

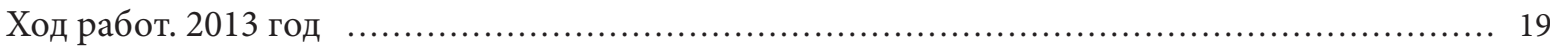

ГЛАВА 4.

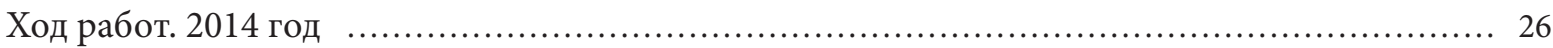

ГЛАВА 5.

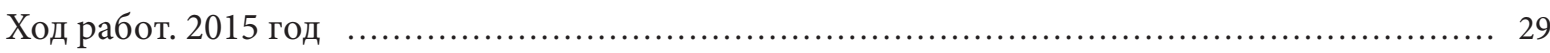

ГЛАВА 6.

Специальные определения по работам 2012-2015 гг. .................................... 34

Остеологические определения. Находки костей животных и раковин

(аналитик Е. В. Добровольская) ...................................................... 34

Данные микробиоморфного анализа (аналитик А. А. Гольева) .......................... 35

ГЛАВА 7.

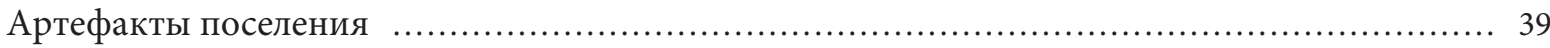

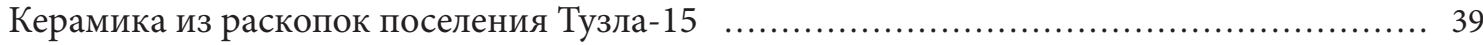

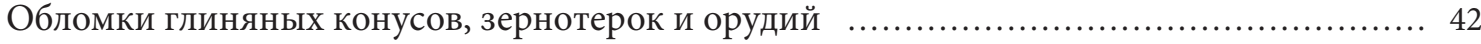

ГЛАВА 8.

Хронология памятника

ГЛАВА 9.

Комплексы ям поселения Тузла- 15 и типология построек

майкопско-новосвободненской общности

Комплексы построек поселения Тузла-15 и бытовые сооружения МHO ................ 45

ГЛАВА 10.

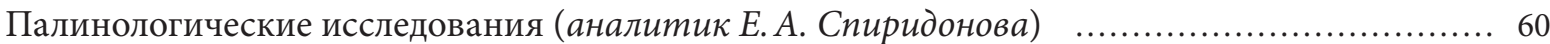

ЗАКЛЮЧЕНИЕ

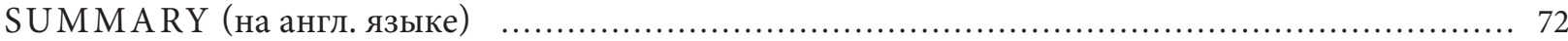

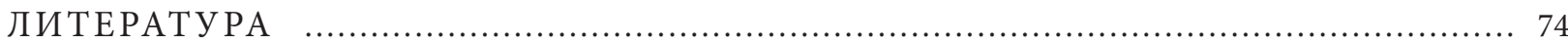

СПИСОК СОКРАЩЕНИЙ

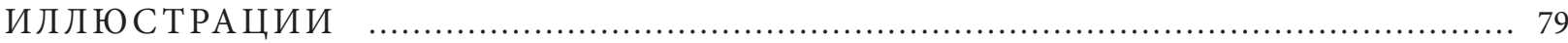




\section{CONTENTS}

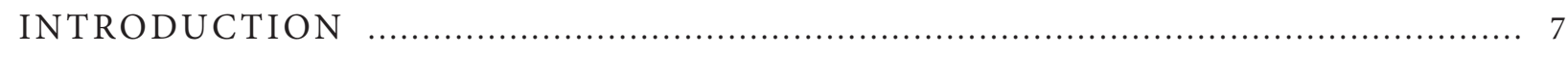

\section{CHAPTER 1.}

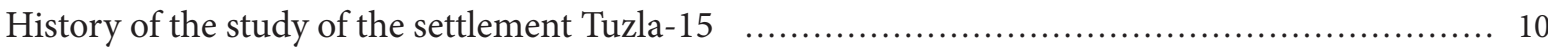

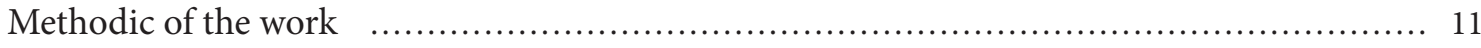

CHAPTER 2.

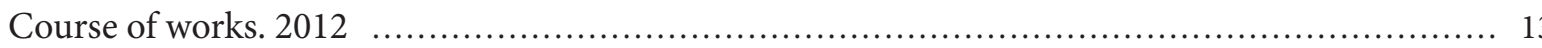

CHAPTER 3.

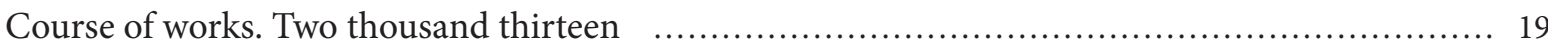

CHAPTER 4.

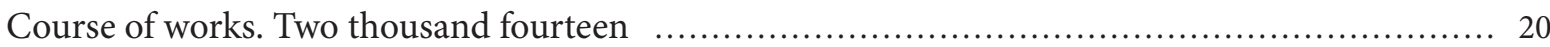

CHAPTER 5.

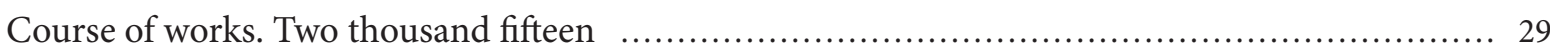

CHAPTER 6.

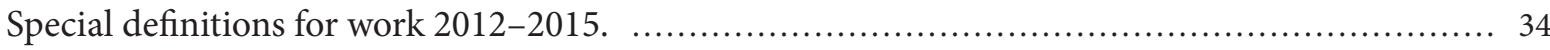

Osteological definition. Finds of animal bones and shells (analyst E. V. Dobrovolskaya) $\quad$........ 34

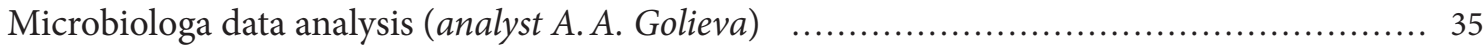

CHAPTER 7.

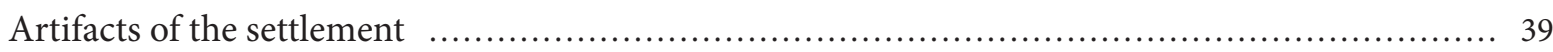

Ceramics from the excavations of Tuzla settlement-15 ...................................... 39

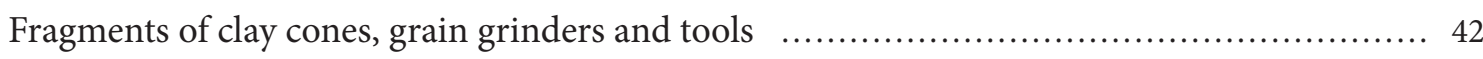

CHAPTER 8.

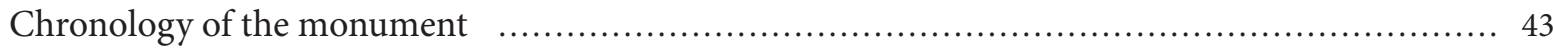

CHAPTER 9.

Complexes of pits of the settlement Tuzla-15 and typology of the buildings

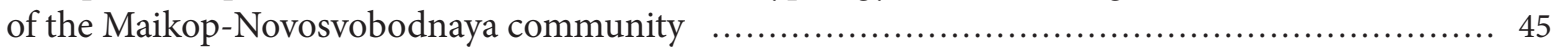

Complexes of buildings of the settlement Tuzla-15 and household structures of MNC $\quad \ldots \ldots \ldots . . .45$

CHAPTER 10.

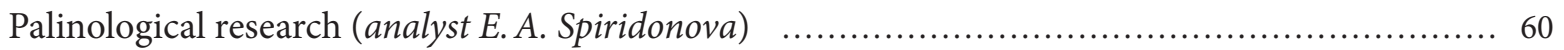

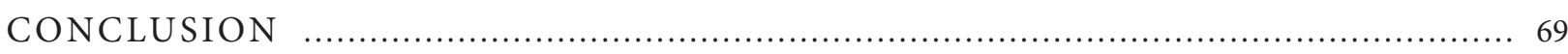

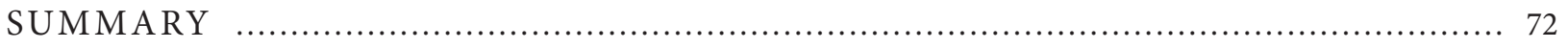

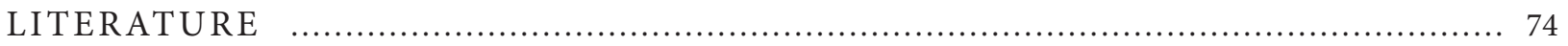

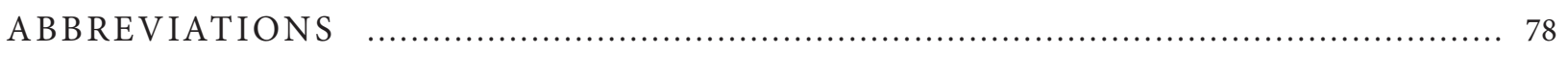

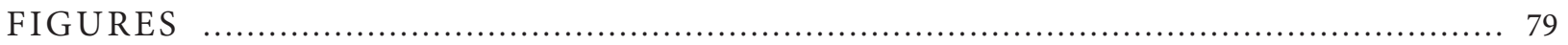




\section{Введение. От автора}

В начале IV тыс. до н. э. в Предкавказье в результате миграции внезапно появились племена земледельцев, скотоводов и воинов с необычно развитой для своего времени материальной культурой (Примечание 1). В те далекие времена оружие из меди и бронзы только-только начало входить в обиход на Кавказе. Однако в среде племен пришельцев уже были искусные металлурги и кузнецы, которые могли изготовлять бронзовые кинжалы, топоры, мотыги, инструменты деревообработки, украшения из цветных металлов высокого престижа и посуду из серебра, золота и бронзы. Их хозяйственный уклад был связан с поверхностным мотыжным земледелием, пастбищным скотоводством, разведением крупного и мелкого рогатого скота, свиней. Они не были кочевниками-номадами, а вели стационарный образ жизни на поселениях вблизи рек, время от времени меняя места стоянок. Колесный транспорт им не был известен, как и освоение лошади под верх. До становления цивилизации шумеров на юге Месопотамии, возникшей в начале III тыс. до н. э., по исторической ленте событий было еще очень далеко, более тысячи лет.

Упомянутые выше пришельцы переселились в долины Кубани и Терека с юга. Характерной чертой производства посуды рассматриваемых племен, по которому археологи пытаются определить культурную идентичность населения, было изготовление разнообразной керамики строго симметричных форм с помощью поворотных устройств из хорошо отмученной (чистой) глины без искусственных минеральных примесей в формовочных массах. Посуда такого высокого сорта явно составляла показатель престижа владельца. Особое значение для археологов приобретает изучение высококлассной керамики, на которой древние гончары оставили различные метки и значки. Такое явление позволяет полагать, что мы сталкиваемся здесь с проявлением признаков протоцивилизации (Кореневский, 2011а; 2013а; 2016б) и с обществом, которое вырабатывало системы передачи и хранения информации в нетленном материале, но уровня появления слого-фонетического письма, характерного для уровня цивилизации (Дья конов, 1979; 1983), они еще не достигли.

Наряду с высококачественной керамикой использовалась лепная кухонная посуда с минеральными искусственными примесями в формовочной массе. В ней готовили пищу. Именно она была предназначена для контакта с огнем.

Ближайшее им население, изготовляющее сходные формы керамики, обитало в Северной Месопотамии, Восточной Анатолии и на равнинах Южного Кавказа.

Самые ранние страницы истории этого пришлого населения в Предкавказье еще прослеживаются с трудом, но где-то 39-37 вв. до н. э. или несколько позже в Центральном Предкавказье зафиксированы огромные курганы, насыпанные над могилами знати этих пришельцев. Один из них, раскопанный Н.И. Веселовским в 1897 г. в г. Майкопе с феноменально богатым захоронением, дал имя их археологической культуре, которая стала называться майкопской. В 1898 г. Н.И. Веселовский исследовал две каменных гробницы в курганах у ст. Новосвободной. Находки в них напоминали комплекс захоронения в Майкопском кургане, но имели и существенные отличия (Мунча ев, 1975, Кореневский, 2008. С. 74-78). Спустя некоторое время среди археологов возникли споры, относятся ли эти выдающиеся памятники Адыгеи к одной культуре или к двум: майкопской и новосвободненской. Чтобы сохранить общее понятие о древностях майкопской культуры, был предложен интегральный термин: майкопско-новосвободненская общность. Изучение всего ее керамического фонда на поселениях 
и погребениях позволило прийти к выводу, что выделенная общность распадается на несколько типологических вариантов. Каждый из них имеет свои устойчивые диагностические типы керамики. Эти варианты получили название майкопского, псекупского, долинского и новосвободненской группы. Сложение каждого из них могло иметь свои особенности (Кореневский, 2004).

Наиболее близки между собой памятники майкопского и псекупского вариантов по наборам типов посуды высокого класса. Они отличны по этому признаку от памятников долинского варианта и новосвободненской группы. Но полной близости между ними нет. Так, среди памятников псекупского варианта выделяются сосуды высокого класса с приземистыми формами. На них плохо прослеживаются знаки-метки. На сосудах псекупского варианта порой фиксируется орнамент пролощенной сеткой или зигзагообразные прочерки на горле, полосы, окрашенные красноватой или коричневой краской, и иные фигуры орнамента.

История изучения майкопско-новосвободненской общности в Причерноморской зоне Краснодарского края связана с раскопками здесь поселений псекупского варианта МНО, которые обнаруживаются под Новороссийском, в Анапском районе. На Таманском полуострове о них мало что было известно. В какой-то мере этот пробел пытается заполнить предлагаемое исследование, посвященное изучению разведочными раскопками культурного слоя поселения Тузла- 15 .

Поселение Тузла-15 было обнаружено в зоне грядущих строительных работ, но последние были отложены на некоторое время. Это дало возможность в течение четырех полевых сезонов исследовать памятник

\section{Примечание 1}

Общее представление о миграчии, теоретический аспект. В решении темы о ранних носителей миграции племен майкопского варианта МНО ещё много «белых пятен». Одни из наиболее древних памятников этого варианта расположены недалеко от перевалов центральной части Большого Кавка- и вести раскопки с максимальной тщательностью. Большую помощь в изучении поселения Тузла-15 оказал Н. И. Сударев, руководитель Восточно-Боспорской экспедиции.

В настоящее время территория поселения находится вблизи от входа на Крымский мост, к западу от ведущего на мост шоссе. Подъезд к памятнику стал непрост и раскопки на нем были приостановлены.

Предлагаемая публикация была задумана как представление нового источника в сопровождении дат ${ }^{14} \mathrm{C}$, данных палинологического и фитолитного анализов, а также как ввод его в научный оборот на фоне текущих проблем исследований майкопсконовосвободненской общности и связанных с ней дискуссий.

В период работы над рукописью я имел возможность ознакомиться с коллекциями близких по керамическому фонду находок поселений Чекон 1 и Чекон Анапского района по раскопкам А.В. Бонина 2010 г., В.В. Бочкового 2011 г. В 2018 г. я был приглашен для работы по новым раскопкам поселения Чекон в экспедицию под руководством А. И. Юдина.

Специальные анализы выполнялись к. г.н. Е.А. Спиридоновой (палинологический очерк), д.г.н. А.А. Гольевой (фитолитный анализ), к. б.н. Е.В. Добровольской (остеологические определения).

Работа рассчитана на археологов, краеведов, историков, а также всех, кто интересуется далеким прошлым Таманского полуострова и необычно ярким феноменом майкопско-новосвободненской общности.

Пользуюсь случаем выразить благодарность А.В. Бонину, В.В. Бочковому, А.И. Юдину за возможность ссылаться на материалы их раскопок.

за. Поэтому роль перевальных трасс через горы Главного Кавказского хребта могла быть очень значимой в процессе распространения пришлого населения с юга в начале IV тыс. до н. э.

В плане теории освещения вопросов о миграциях можно сказать, что в эпоху до- 
государственного периода в культурах ранних земледельцев и скотоводов миграции играли важную роль в культуро- образовании. Они отражали перемещения групп людей и служили причинами для появления новых культур и сложения новых этносов. Хороший обзор теории проблемы изучения миграционных движений по материалам Американского континента написал Д. Энтони (Antony, 1990). Важные аспекты в изучении миграционных перемещений по данным этнологии и археологии рассматривались на симпозиуме, посвященному этому явлению, в Новосибирске в августе 2019 года в работах А. В. Головнева (2019), В.И. Молодина (2019), Д. Г. Савинова (2019) и иных.

По данным исторической этнологии возможно рассматривать разные группы причины миграционного движения такие как, демографические, политические, экономические. Демографические причины были обусловлены избытком населения на производственный ресурс занимаемой территории и стремлением молодежи отделиться найти новые земли для своего существования. Политические причины, побудившие к миграционным перемещениям, известны на примере африканского народа матабеле 20-х годов XIX века. Лидер группы родов Моселекатсе, опасаясь возникновения враждебных отношений с верховным вождем зулусов Чакой, откочевал из провинции Трансвааль со своим народом и захватил земли племени шона (ныне юго-восток Зимбабве). В итоге образовался новая общность во главе с пришлыми родами Моселекатсе и подчиненными им аборигенами (Потехин, 1951, с. 34)

Экономические причины, побуждающие к миграциям групп земледельцев и скотоводов были различны. Среди них можно назвать такие как перемещения в связи с изменениями климата, причины, обусловленные особенностью хозяйственно-культурного типа скотоводов и ранних земледельцев с мотыжной обработкой почвы и, видимо, ряд иных.

В миграциях могли принимать участие массы населения, которые несли с собой особенности своей материальной и духов- ной культуры. Не редко миграцию отражают появившиеся в определенном месте керамические комплексы или необычные для данной территории погребальные обряды, которые иллюстрируют новый быт и верования пришельцев.

Еще одним из типов миграций эпохи ранних земледельцев и скотоводов могли быть перемещения кланов специалистов, носителей особо важных технологий, например, таковыми были миграции кузнецов и металлургов. Так, по легендам масаев, первый кузнец пришел к ним из других земель и женился на женщине из рода этого племени. Кузнецы масаев были прежде сего оружейниками. Их быт был отделен от жизни обычных аграриев (Cline, 1937).

Другие легенды жителей оз. Мосенгере и Басаката в Африке повествуют, что несколько поколений назад племена, умеющие обрабатывать железо, вторглись в их район с севера и остановились здесь, что бы рыть шахты и плавить металл. Они вступили в контакт с местным населением. Через некоторое время пришельцы Ba Sokata ушли на юг. При уходе они сожги все свои хижины и разбили плавильные печи (Cline, 1937).

И наконец, поводом частных перемещений людей могут служить вещи, происхождение которых связывается с удаленными территориями от пункта находки. Но в таком случае это дает лишь повод для постановки проблем о перемещениях людей или косвенное свидетельство о них, так как вещь могла передаваться из рук в руки на значительные расстояния в качестве дарообменных операций.

По данным археологии далеко не все причины миграций возможно фиксировать. Вопросы о том, какие из них могли иметь место в случае появления и расселения племен, носителей будущей майкопско-новосвободненской общности и её вариантов, являются весьма актуальными. Одни из них автор пытается отразить в предлагаемом издании, но полностью освещение проблемы о миграциях носителей майкопско-новосвободненской общности не входит в настоящую работу. 


\section{ГЛАВА 1. \\ История исследования поселения Тузла- 15}

Поселение Тузла-15 находится в западной части Таманского полуострова, западнее пос. Тамань Темрюкского района Краснодарского края, примерно в 2 км от современного берега Черного моря. Неподалеку от места поселения располагается поселок Волна. Поселение Тузла- 15 было открыто С.А. Буравлевым, сотрудником Восточно-Боспорской экспедиции Института археологии РАН, в ходе разведочных работ в 2011 г. для расширения площади для строительства порта (рис. 1, 1; рис. 2; рис. 3). Оно локализовалось на невысоком всхолмлении, соседствуя с балкой, по которой когда-то в древности могла протекать вода. Поселение с запада на восток пересекала проселочная дорога и линия электропередачи (рис. 1, 2).

В результате шурфовки 2011 г. в западной части площади, намеченной под строительство, были обнаружены черепки охристой керамики майкопско-новосвободненской общности и реконструирована характерная для нее миска.

В 2012 году Н.И. Сударев, начальник Восточно-Боспорской экспедиции, поставил задачу конкретизировать характер культурного слоя поселения и его объектов. С этой целью я был приглашен для работы в состав экспедиции, и в ней была организована небольшая «майкопская» группа для исследования обнаруженного поселения раннего бронзового века. Открытый лист в 2012 г. на работы на поселении Тузла-15 был выписан на имя Н.И. Сударева. Для привязки на местности раскапываемых объектов мы использовали линию столбов, данные JPS и линейные координаты по азимуту. В 2012-2014 гг. азимут определялся по туристическому компасу. В 2015 г. использовалась для этой цели артиллерийская буссоль с минимальной ошибкой до 1 градуса.

Объем вскрываемой площади в 2012 г. ограничивался $20 \mathrm{~m}^{2}$. В ходе работ был вы- копан шурф 1 (раскоп 1) размером $4 \times 4$ м. В нем напротив столба № 5 электропередачи были найдены мелкие фрагменты майкопской керамики. Далее было выбрано новое место для разведки напротив столба 7 , и заложен квадрат 2 площадью $4 \times 4$ м (раскоп 2).

Результаты работ в нем были более информативными. Так, были обнаружены развалы керамики, кости животных, зернотерки и яма со ступенькой, которая, скорей всего, была жилищем. В итоге работ 2012 г. были получены первые сведения о структуре надматерикового слоя поселения в целом, характере собственно культурного слоя памятника. Отобраны пробы для палинологического и радиоуглеродного анализа (Сударев, 2013; Кореневский, Сударев, 2013).

В 2013 г. в связи с тем, что заказчик отложил сроки финансирования строительства объекта Тузла-15, возникла возможность продолжить разведку культурного слоя поселения. Они проводились по Открытому листу С.Н. Кореневского в рамках работы Восточно-Боспорской экспедиции.

В 2013 г. были выбраны места для двух шурфов, в пределах которых оказались открытыми два строения. Они были незначительно углублены в материк. Рядом со строением 12013 г. зафиксирована яма со скелетом теленка (Кореневский, 2014). В 2014 г. на поселении были вырыты два шурфа № 1 и № 2 с целью разведки культурного слоя. В квадрате 1 зафиксирована часть ямы с пеплом, заполненной черепками 1 и 2 класса, костями животных (рис. 2). В раскопе 6 (квадрат 22014 г.) находок практически не было (Кореневский, 2014)

В 2015 г. я отыскал квадрат 12014 г. Вокруг него был заложен небольшой раскоп 5. В результате было найдено очередное жилище. Далее были вырыты два раскопа 7 и 8 (квадраты 6 и 72015 г.) на восточной периферии всхолмления. В раскопе 7 находок 
практически не было. Раскоп 8 был законсервирован для следующих раскопок (Кореневский, 2015) (рис. 2).

\section{Методика исследования}

Методика изучения поселений майкопско-новосвободненской общности имеет свою специфику в зависимости от задач исследования, особенностей культурного слоя, но в настоящее время она находится еще в стадии эмпирического накопления данных. Опубликованных сведений о том, как копаются поселения майкопско-новосвободненской общности, не много. Поэтому в данный момент главным руководством для изучения поселения майкопской культуры является «Положение о порядке проведения археологических работ и составления научной отчетной документации» М., 2014.

Применительно к данному объекту методические приемы использовались для главной задачи - разведки характера культурного слоя в случае обнаружения бытовых объектов, и их изучения. Проводить раскопки широкими площадями мешало отсутствие финансирования работ. Поэтому наша работа является описанием именно разведочного цикла исследований, позволяющего составить впечатление о характере культурного слоя и обнаруженных в нем объектов.

Пахотный слой на поселении достигал 60 см и мог быть пройденным на полный штык с суммарной фиксацией находок, но с обязательным соблюдением ритмаштык вниз - зачистка по горизонту.

Третье. После выхода на верхний уровень культурного слоя непременным условием раскопок становятся горизонтальные зачистки при опускании поверхности раскопа на глубину 5-10 см. При появлении первых находок каменных предметов или керамики немедленно производится горизонтальная зачистка всей площади раскопа с соответствующей фиксацией ситуации.

Четвертое. Если в результате зачистки появляются контуры пятна, то с ним начинается специальная работа. Производится его оценка, входит ли оно в площадь рас- копа или нет. Если пятно уходит в борт раскопа, то возможна прирезка квадратным методом для оконтуривания всего пятна. Вместе с тем должно быть принято решение, надо ли это делать, исходя из возможности времени и сил, так как прирезаться подобным образом и расширять объем работ можно до бесконечности.

Пятое. Работа в зоне пятна производится «на скальпель», то есть с максимальной тщательностью расчистки с фиксацией находок по уровням опускания вниз до дна конструкции. Фиксация находок и ситуаций производится поэтапно. Желательно было максимально полно сохранить расположение находок (керамики, костей животных) в первоначальном положении для наиболее объемной фиксации. Разбор находок в яме происходит только после их полной фиксации.

Шестое. Существующие рекомендации изучать яму, заполненную находками, по частям могут быть приняты не только как положительный методический прием, но и как отрицательный, поскольку в первом случае нарушается горизонтальная стратиграфия залегания находок в площади ямы строения. Здесь все зависит от конкретной ситуации. Что это за яма? Не является ли она котлованом полуземлянки?

Седьмое. При чертежных работах многое зависит от размеров фиксируемого объекта. Допустимы масштабы чертежа 1:20, 1:10, 1:5, 1:1 (последние для особых ситуаций).

Далее возможно сказать, что необходимо соблюдать общие правила ведения раскопок, чертежных работ, фотофиксации материалов и комплексов, прописанных в различных методических пособиях и в Положении о раскопках ОПИ.

При описании фрагментов керамики поселения Тузла-15 мы используем понятия, применимые для изучения этого рода археологических источников на основании терминологии, разработанной А.А. Бобринским (Бобринский, 1978), а также на базе классификации керамики майкопско-новосвободненской общности, предложенной в 2004 г. автором этих строк (Кореневский, 2004. С. 22-35). 
Таковы понятия керамики 1 класса без видимых искусственных минеральных примесей в формовочной массе и класса 2 с видимыми искусственными минеральными примесями в формовочной массе.
Для работы с керамикой перспективным представляется фотографирование объекта и его сильное увеличение для исследования деталей предмета или орнамента, то есть макрофотография. 


\section{ГЛАВА 2. Ход работ. 2012 год}

В 2012 г. были начаты разведки по уточнению культурного слоя поселения Тузла- 15 . С этой целью было раскопано два шурфа $4 \times 4$ м. Шурфы ориентировались по осям координат. Выбор места закладки шурфа 1 был произвольным, так как рельеф поверхности никак не мог подсказать оптимальное место для раскопок.

Привязка шурфа на общем плане строилась относительно линии электропередачи. Для установления координат использовался GPS навигатор Garmin 60CSX. Точность (диаметр) поправки координат составляет 2-3 м. Ниже приводятся некоторые координаты опорных столбов электропередачи для конкретизации общей ситуации на поселении.

Координаты углового (реперного) столба линии электропередачи, от которого велся отсчет столбов: N $45^{\circ} 10^{\prime} 791$ ' Е $036^{\circ} 37^{\prime}$ 706”. Координаты по GPS столба № 3 (или столба 4 при отсчете от R столба, включая последний) напротив шурфа 1: N 45 10' 792” Е $036^{\circ} 37$ ' 888”. Координаты по GPS у восточного окончания всхолмления: $\mathrm{N} 45^{\circ}$ 10'794' Е $036^{\circ} 38^{\prime} 122$ '.

В целом расстояние от реперного столба до восточной границы всхолмления по линии 3-В составляет около 640 м. Южная граница поселения очерчивается балкой, северная граница визуально неопределима, так как местность плавно повышается с юга на север.

Для отметок высот для всего поля обследования был выбран РЦ у основания 3-го столба электропередачи - 0 см. (Ро 19,65 на карте, рис. 2). Репер северо-западного угла шурфа $1+20$ см. Репер северо-западного угла шурфа $2+38$ см.

Отметки глубин в каждом шурфе автономны и брались от локального реперцентра на поверхности земли у северо-западного угла квадрата. При пересчете на абсолютное значение глубин для шурфа 1 поправка составит
-20 см, для шурфа 2 -38 см. Для конкретных промеров глубин поправки не вводились, так как важна была конкретная ситуация с глубинами залегания слоев и артефактов на квадратах, стратиграфия которых подчинялась естественному подъему или опусканию напластований почвы.

Абсолютная высота местности отмечалась по GPS высотометру. Показатели глубин на дне балки напротив столба 3 около 8 м. У шурфа 1 - около 9 м над уровнем моря. Для шурфа 2 - около 10 м. Таким образом, подъем берега балки, на котором закладывались шурфы, по отношению к ее дну составляет около 1-2 м. Понижение уровня поверхности земли прослеживается в направлении с севера на юг и с востока на запад.

\section{Раскоп 12012 г.}

Раскоп 1 (шурф 12012 г.) (рис. 4; 5; 6) площадью $4 \times 4$ м был разбит напротив столба № 3, на расстоянии 30 м к северу от него. Ориентация стенок шурфа по линии СЮ3В. Координаты юго-западного угла шурфа: N 4510'810" Е $036^{\circ} 37$ ' 888', Поверхность шурфа распахивалась. К моменту раскопок она попала под боронование. За реперную точку 0 принят северо-западный угол шурфа. Для удобства фиксации материала площадь шурфа разбивалась на четыре части $2 \times 2$ м, получившие по часовой стрелке названия квадратов А, Б, В, Г.

Штьк 1. Глубина в основании - около -20 см. Снимаемый грунт представляет собой комковатый слой распашки. Глубина штыка 1 составляет около -20 см. На 1 штыке было найдено 12 мелких фрагментов керамики. Три фрагмента имеют охристый цвет и плотное тесто без видимых на глаз примесей. 10 черепков относятся к лепной керамике с видимыми на глаз примесями. Помимо этого зафиксирован обломок морской раковины. 
Штык 2. Глубина в основании - $-41,-49$, $-52,-47$ см. Снимаемый грунт рыхлый серочерного цвета. Найдено 27 мелких фрагментов керамики, не образующих скопления. Из них 14 фрагментов охристого цвета с плотным тестом. 13 фрагментов лепной керамики были серого и бурого цвета с минеральными примесями в тесте. Среди охристой керамики встретился венчик с наплывом и фрагмент реберчатой миски. Найден фрагмент ручки круглого сечения, возможно, античного времени.

Штык 3. Глубина в основании - -62, -70, $-69,-68$ см. Снимаемый грунт не меняет структуру и плотность. Найдено более 50 мелких фрагментов керамики охристого и в основном серого и бурого цветов с минеральными примесями, не образующих скопления, одна створка раковины. Среди фрагментов керамики присутствует обломок венчика крупной миски майкопской культуры.

Штъљк 4. Глубина в основании - -81, -91 , $-87,-90$ см. Снимаемый грунт изменил плотность и цвет. Он имеет серый окрас и плотную структуру. Найдено 16 мелких фрагментов керамики. Из них один фрагмент охристый и 15 черепков черного цвета с минеральными примесями и обломки раковин. В основании штыка начали встречаться белесые конкреции карбонатов. Слой прорезан кротовинами.

Штъљк 5. Глубина основания штыка --108, $-116,-114,-116$ см. Снимаемый грунт имеет желтоватую окраску плотного суглинка, насыщен беловатыми включениями карбонатов. Найден один черепок лепной керамики с крупными минеральными примесями. Его попадание в слой связано с кротовиной.

Стратиграфия раскопа 1 (рис. 5) представлена одинаково на всех четырех стенках квадрата. Глубина слоя 0-60 см отражает слой распашки, размельченный комковатый черного цвета. Глубины 60-80 см включают грунт из плотного серого суглинка. Глубины 80-100 и глубже связаны с плотным желтоватым суглинком, насыщенным карбонатами.

Выводы. Материковый слой выявлен на глубине перехода от четвертого штыка к пятому (80-100 см от РЦ квадрата). При- знаками приближения к материку являются карбонаты. Сам материковый слой почвы был ими обильно насыщен. Выше материкового на глубинах 4-го штыка (60-80 см) располагается надматериковый нетронутый слой древней почвы, слабо насыщенный фрагментами керамики. Его можно рассматривать, как низ культурного слоя.

На глубинах -60 см и выше, почва разбита распашкой и насыщена керамикой. При этом ее наибольшая концентрация связана с третьим штыком. Наиболее показательны среди полученной коллекции черепков фрагменты охристой керамики майкопсконовосвободненской общности. Они позволяют ставить вопрос, что слой поселения имеет в данном квадрате мощность примерно 40 или 60 см от материка и сильно разбит в верхней части пахотными работами.

В восточной стенке раскопа отобраны пробы для палинологического анализа (рис. 6). Они уточняют стратиграфию слоев шурфа. Находки керамики встречаются до слоя желтого плотного суглинка, насыщенного карбонатами на глубинах 80-90 см.

Колонка проб такова:

1 55-60 см слой пахоты, черный комковатый грунт

2 60-65 см серый суглинок культурного нетронутого слоя

3 65-70 см серый суглинок культурного нетронутого слоя

4 70-75 см серый суглинок культурного нетронутого слоя

5 75-80 см серый суглинок культурного нетронутого слоя

6 80-85 см желтый материковый суглинок с карбонатами

7 85-90 см желтый материковый суглинок с карбонатами

8 90-95 см желтый материковый суглинок с карбонатами

9 Проба грунта для датирования взята на глубине 65-70 см.

Раскоп 22012 г.

Раскоп 2 (шурф 2) имеет размер $4 \times 4$ м и разбит по осям координат (рис. 7, 1; рис. 8). Его юго-восточный угол имеет засеч- 
ку 18 м к северу от линии электропередачи и на 2 м к западу от столба № 6. Координаты этой точки по GPS N $45^{\circ} 10^{\prime} 807^{\prime}$ ' E $036^{\circ}$ 37' 973'. Высота от уровня моря 10 м. Поверхность шурфа подвергалась регулярной распашке. За отметку «0» принят с-з угол квадрата. Раскоп 22012 г. отстоит на 111 м от раскопа 1 на восток. Для удобства записи находок квадрат разбит на 4 сектора $2 \times 2$ м $(\mathrm{A}, \mathrm{Б}, \mathrm{B}, \mathrm{\Gamma})$.

Штык 1. Заполнение штыка представляет собой комковатый серо-черный грунт распаханного поля. Глубина раскопки составляет около 20 см. На 1 штыке найдено 11 фрагментов керамики. Из них 6 фрагментов охристой майкопской посуды, в том числе венчик от сосуда (рис. 7,2 ) а также круглая в сечении ручка, вероятно, античного времени. Ручка имеет красный цвет. Вместе с ними встретилось 5 фрагментов лепной керамики черного цвета.

Штъљк 2. Перед началом раскопок второго штыка поверхность квадрата была выровнена. Раскопки велись на глубину 20 см в связи с тем, что мы находились еще в зоне распашки. Находки отмечались на плане. Заполнение штыка составляет комковатый серо-черный грунт. При окончании вскрытия квадрата на 2 штыке объект был выровнен. Отметки основания штыка по углам - $41,-48,-47,-48$ см.

Объекты, зафиксированные в плане, таковы. На пересечении секторов А и Б найдена зернотерка-камень-ракушечник, имеющий в длину 40 см и высоту 32 см. Юговосточнее его в секторе Б зафиксирован обломок зернотерки из пористого камня основанием на гл. -42 см. Вдоль восточного борта раскопа в секторах Б и В проступает развал керамики на глубинах $-45,-47$ см. Его доследование будет проведено позже, как прирезка к восточному борту шурфа.

В секторе А найден керамический шлак. По всему квадрату попадались фрагменты керамики и кости животных мелких и крупных копытных. Среди них есть нижняя челюсть овцы в секторе Г и бабка какого-то крупного копытного животного в северной стенке сектора Б. В целом на 2 штыке найдены 38 фрагментов керамики (рис. 9, рис. 10). Среди них есть венчик сосуда 1 класса с острорельефным отгибом (рис. 7, 2), два скола кремня (рис. 9, 5, 6), фрагмент плоского дна черного цвета (рис. 9, 3, 4), черепок с поверхностями разного цвета: черной снаружи и красной изнутри (рис. 9, 1), головка полой приставки (рис. 10, 13), фрагмент плоского дна с отпечатками циновки (рис. 10, 1).

Раковин устриц найдено три штуки. Раковина гребешка (с рифлением) - 1 шт.

Штык 3. Раскопки штыка 3 проводились по секторам на глубину 10 см. Найденный материал сразу фиксировался на плане. Заполнение штыка составляет плотный серый грунт. Он явно менее подвергался распашке, чем выше лежащие слои. Отметки глубин основания 3 штыка $-59,-60,-57$, -59 см.

Объекты раскопок таковы. В северозападном углу сектора А найден фрагмент зернотерки из пористого камня (рис. 10, 2). Фрагмент лежит плоской поверхностью вниз. На ней прослеживаются красные пятна ожелезненной породы (охры). В центре сектора А найден камень ракушечник со следами жжения.

По всему квадрату встречены мелкие фрагменты керамики, кости животных и створки раковин устриц. Найдена одна галька мелкой формы без следов использования.

В северо-восточной части сектора Б найден фрагмент широкой ленточной ручки для сосуда с черной поверхностью и минеральными примесями (рис. 10, 3).

Всего на штыке 3 найдено 73 фрагмента керамики. Черепков без минеральных примесей в тесте майкопской культуры - 11 . Из них два фрагмента мисок черного цвета и один красного цвета. Остальные черепки стенок охристого цвета. Черепков с минеральными примесями найдено 62. Из них четыре венчика, одно - плоское дно. Четыре фрагмента имеют двойную окраску: красную или бежевую внутреннюю поверхность и черную внешнюю.

Створок раковин устриц найдено 6 . Створка раковины гребешка - 1 (в восточном профиле квадрата). 
Штык 4. Заполнение четвертого штыка составляет плотный серый грунт. Глубина основания штыка $-76,-75,-73,-74$ см (рис. 11). На глубине -66 см проступают первые карбонаты. На глубинах около -70, -75 см их становится много. Вывод из этого таков. Глубины от -66 до -80 см связаны с культурным слоем, который находится в предматериковой зоне и ниже которого залегает геологический материк.

Находки штыљка. На плане раскопа 2 на 4 штыке расчистки (рис. 11, рис. 12) найдена зернотерка и фрагменты керамики. Зернотерка из камня-ракушечника квадратной формы, лежит плоско-вогнутой поверхностью вниз (рис. 13). Фрагмент венчика охристого кругового майкопского сосуда на глубине 73 см зафиксирован у южной границы сектора В. Крупный фрагмент верхней части сосуда с минеральными примесями черного цвета находится на той же глубине -72 см и в 60 см к северу (рис. 14, 1). Фрагмент плоского дна диаметром 14 см от сосуда с минеральными примесями черного цвета (рис. 14, 7). Под ним на глубине -70 см лежит кость ноги животного. Керамика охристого цвета (майкопско-новосвободненской общности) без видимых на глаз минеральных примесей встречена вместе с лепной керамикой черного цвета и с крупными минеральными примесями. По основанию штыка 4 проведена зачистка.

Всего на штыке 4 найден 91 фрагмент керамики. Это 10 фрагментов керамики без видимых на глаз минеральных примесей. Из них 3 венчика сосудов (рис. 15, 1, 3, 4) и два венчика мисок. Фрагментов керамики с минеральными примесями найден 81. В основном это стенки сосудов. Встречены фрагменты сосудов с двухцветной поверхностью, красной изнутри и черной снаружи. Найден обломок основания глиняного конуса (рис. 15, 7).

Зачистка квадрата выявила две ямы (рис. 11). Яма 1 находится в секторе Г. У другой ямы 2 в площадь раскопа попадает только небольшая часть в секторе А.

Постройка 1. Яма 12012 г. Первая зачистка, которая выявила контуры ямы, проведена на глубине -73, -76 см. Пятно ямы выде- ляется темно-серым цветом от окружающей желтоватой поверхности предматерикового слоя, насыщенного карбонатами. Пятно имеет форму неправильного овала немного вытянутого с юго-запада на северо-восток. Длина ямы по линии ЮЗ-СВ - 222 см, по линии ЮВ-СЗ - 180 см.

Яма раскапывалась двумя секторами: сначала северным (рис. 16), затем южным. Профиль зачерчен и сфотографирован с северной стороны. Он подтверждает, что заполнение ямы составляет однородный темноватый суглинок. Яма немного сужается ко дну и несколько меняет контуры. Ее размер по линии 3-В составляет-222 см, по линии С-Ю - 200 см. Дно ямы находится на глубине - 116 см. В юго-восточной части ямы выявлена ступень. Длина ступени по линии Ю3-СВ - 140 см, ширина ступени по линии ЮВ-С3 - 36 см. Глубина ступени - 96 см (то есть она ниже поверхности зачистки на 22 см).

Дно ямы, таким образом, имеет длину по линии ЮЗ-СВ - 190 см, ширину по линии ЮВ-СЗ - 150 см (рис. 16; рис. 17).

При расчистке ямы найдены кости копытных животных и птицы. Всего зафиксировано 76 фрагментов керамики. В основном это стенки сосудов. Из них черепков без видимых на глаз примесей - 9, в том числе 1 фрагмент миски. Фрагментов с минеральными примесями найдено 68. Фрагментов стенок конуса - 1 с частью отверстия и наколом под ним, а также фрагмент стенки конуса. Створок раковин устриц найдено 6 .

Яма 2. Часть пятна ямы 2 (сегмент) выявлена в северо-западном углу сектора А. Ее длина по северной стенке 100 см, по западной 85 см. Яма прокопана до дна, расположенного на глубине - 96 см. Заполнение ямы состоит из суглинка темного цвета. Найден один фрагмент лепной керамики.

Стратиграфия шурфа 22012. При фиксации стратиграфии шурфа 2 мы уже располагали данными стратиграфии раскопа 1. По результатам работ в раскопе 2 мы явно дошли до уровня предматерикового горизонта, который с глубины 66 см маркировался карбонатами. Глубины -75 - -79 см указывали низ культурного слоя, глубже ко- 
торого находится геологический материковый слой.

В связи с этим мы заложили стратиграфические траншеи только вдоль северной части восточной стенки, не вынимая весь грунт на пятом и шестом штыках со всей площади квадрата. В итоге мы получили следующие данные по профилям раскопа.

Северныци профиль (рис. 18). На глубине 40 см от поверхности слой (a) сильно разбит распашкой. Он имеет серо-черный цвет и комковатую структуру. Ниже, на глубине -60 - -80 см располагается плотный серый слой с культурными отложениями (в). Горизонт карбонатов начинается с уровня -66 см и усиливается с глубины -80 см. На глубине -80 и ниже имеет место залегание материкового желтоватого суглинка, насыщенного карбонатами (с). Глубина стратиграфической траншеи доведена до -116 см. В западном окончании профиля прослеживается темный след ямы 1, уходящий в стенку раскопа. Глубина дна ямы -96 см. Уровень верха фиксации -80 см.

На глубине -48 см в профиль входит кость крупного копытного животного. На глубине -48, $-50,-55$ см в секторе А в профиль входит небольшой камень и кость животного. На глубине -55 - -60 см отмечен фрагмент охристой майкопской керамики. На глубине -78 см найден фрагмент зернотерки.

Восточный профиль (рис. 18). На глубине -40 см от поверхности слой (а) сильно разбит распашкой. Он имеет серо-черный цвет и комковатую структуру. Ниже, на глубине -60 - -80 см располагается плотный серый слой с культурными отложениями (в). Траншея для исследования материкового слоя заложена в северной части профиля на расстоянии 2 м к северу, то есть в секторе Б. Слой в виде материкового желтоватого суглинка, насыщенного карбонатами (с) прослеживается с глубины -80 см и до глубины -120 см (окончания зондирования). На глубине -110 см в кротовине встречены два лепных черепка. Более никаких находок нет.

Очень важные данные прослеживаются в верхних глубинах профиля в виде фиксированных ранее развалов керамики, которые мы законсервировали в стенке. Развал
P-1 находится на глубине -39 см. Развал Р-2 лежит на глубине -40 см. Развал Р-3 находится на глубине -50 - -52 см. Развал Р-5 (майкопская миска черного цвета) залегает на глубине -50 см. И, наконец, фрагмент лепной майкопской керамики лежит на глубине $-76--79$ см.

Әти наблюдения указывают явно на определенные напластования культурного слоя. Нижний уровень залегает на предматериковом слое в зоне карбонатов на глубинах -76 - -80 см. Верхний уровень отложен в виде горизонтального залегания керамики на глубине -39, -42, -50 см. Возможно, культурный слой находится в почве и выше, но здесь он сильно разбит распашкой. В целом доказуемая мощность культурного слоя составляет до 40 см.

Южный профиль (рис. 19). Южный профиль раскопа отснят до глубины -80 см, так как в него входит яма 1 и поверхность окружающего ее предматерикового слоя. На глубине 40 см от поверхности слой (а) сильно разбит распашкой. Он имеет серо-черный цвет и комковатую структуру. Ниже, на глубине -60 - -80 см располагается плотный серый слой с культурными отложениями (в). Переход к предматериковому слою отмечен на глубинах -70 - -80 см. В секторе Г прослеживается вход ямы 1 в профиль. Ее дно находится на глубине -110 см, верх ямы фиксируется на глубине -70 см.

Западный профиль (рис. 19) отснят до глубины -80 см, то есть до начала предматерикового слоя. На глубине 40 см от поверхности слой (a) сильно разбит распашкой. Он имеет серо-черный цвет и комковатую структуру. Ниже, на глубине -60 - -80 см располагается плотный серый слой с культурными отложениями (в). Слой предматерикового суглинка (c) начинается с глубины -66 см. В северном окончании профиля прослеживается яма 2. Ее дно находится на глубине -96 см. Верх на глубине -66 см.

Прирезка к иурфу 2 (рис. 20; рис. 21, 1). Прирезка к шурфу 2 сделана с восточной стороны для того, чтобы расчистить развалы керамики, выявленные в восточной стенке раскопа. Ширина прирезки 60 см. Глубина прирезки -32 - -45 см. Прирезка выявила 


\section{Радиокарбонные определения}

\begin{tabular}{|c|l|l|l|l|l|}
\hline № & \multicolumn{1}{|c|}{ Объект } & \multicolumn{1}{|c|}{ Шифр } & \multicolumn{1}{|c|}{ ВP } & \multicolumn{1}{c|}{ ВС } & \multicolumn{1}{|c|}{ Примечания } \\
\hline 1 & $\begin{array}{l}2012 \text { г. Раскоп-2, кость } \\
\text { животного }\end{array}$ & Ki-17989 & $4230 \pm 30$ & $2920-2700$ & $\begin{array}{l}07.02 .2013 \\
82 \text { гр. Шт. } 3\end{array}$ \\
\hline 2 & $\begin{array}{l}2012 \text { г. Раскоп 2, кость } \\
\text { животного }\end{array}$ & Ki-17990 & $4170 \pm 30$ & $2880-2580$ & 85 гр. Шт. 4 \\
\hline 3 & $\begin{array}{l}2012 \text { г. Раскоп 2, кость } \\
\text { животного 3 }\end{array}$ & Ki-17991 & $4180 \pm 60$ & $2880-2660$ & $\begin{array}{l}85 \text { гр. Шт. 4 яма. } \\
\text { Постройка 1 }\end{array}$ \\
\hline 4 & $\begin{array}{l}\text { 2012 г. Раскоп 2 штык 4, } \\
\text { кость животного }\end{array}$ & Ki-17861 & $4310 \pm 110$ & $3081-2876$ & Культурный слой \\
\hline
\end{tabular}

практически «ковровое» залегание черепков в комковатом грунте второго штыка. Всего здесь отмечено 84 фрагмента керамики. Три черепка имеют охристый цвет и структуру без видимых на глаз минеральных примесей. 79 имеют минеральные примеси в тесте. Из них 5 венчиков, остальные стенки сосудов (рис. 22). Интересен фрагмент с тремя вертикальными продолговатыми налепами (рис. 14, 10). Ниже развала черепков в профиль входит створка раковины гребешка (рис. 21, 2), относящейся к штыку 4. После фиксации развалов раскопки приостановлены, так как такие работы уже выходили за рамки проводимой разведки.

Были получены 4 даты для определения возраста находок в шурфе 2. Три из них относятся к костям животных из постройки 1. Одна дата связана с находкой в культурном слое на глубине 4 штыка, то есть в непосредственной близости к карбонатному слою. Все даты очень близки и дают диапазоны 31-29 вв. до н. э.; 30-28 вв. до н. э.; 29-26 вв. до н. э.; 29-27 вв. до н. э. 


\section{ГЛАВА 3. Ход работ. 2013 год}

В 2013 г. по опыту прошлогодних работ я уже знал, что раскопки ведутся в зоне т.н. таманских «каштановых черноземов». Глубина распашки составляет 60 см. Слой распашки имеет бурый или коричневатый окрас, комковатую структуру. Культурный слой имеет пепельный (серый) цвет. Переход к материку прослеживается на глубинах около -80 - -90 см. Материк представлен желтоватым суглинком с включениями карбонатов. Слой предматерикового дерна не прослеживается.

\section{Раскоп 3. 2013 г.}

Раскоп 3 (шурф 1) 2013 г. был начат с работ на площади $4 \times 4$ м, расположенной между шурфами 1 и 22012 г. Квадрат 12013 г. был ориентирован по сторонам света. Углы обозначены через буквы А, Б, В, Г. Внутри раскопа 3 выделены квадраты $2 \times 2$ м № 1, 2, 3,4 для удобства ориентации внутри пространства (рис. 23-27).

Ориентиры раскопа 3 таковы. Точка угла В (юго-восточный угол) отстоит от столба № 6 линии передач на север - 22,50 м, на запад - 2 м. N 45 10' 48.4'; Е $036^{\circ} 37^{\prime} 55.9^{\prime}$. За реперную отметку отсчета высот принято основание бетонного столба № 7. Нивелировочные отметки угла А - 5 см, Б - 3 см, В +3 см, Г - 7 см. Поверхность квадрата несет следы распашки. Слой распашки начал сниматься на полный штык.

Штык 1. 0-20 см. Основание штыка находится на глубине -20, -18, -19, -24 см. Заполнение штыка составляет комковатый грунт каштановой почвы. Находок нет.

Штык 2. 20-40 см. Основание штыка $-31,-23,-30,-41$ см. Заполнение штыка - комковатый грунт каштановой почвы.

Находки. Керамика лепная с примесями белой ракушки, черного цвета и двуцветная, а также лепная керамика с черным изломом - 6 шт. Фрагмент охристой майкопской керамики без примесей - 1 шт. Найден 1 обломок ракушки.

Штъљ 3. Основание штыка $-48,-45,-45$, -60 см. Заполнение штыка составляет комковатый грунт каштановой почвы. Находки концентрируются г. о. в квадрате 3 , юго-восточном секторе раскопа. Здесь найдены небольшой фрагмент зернотерки из ракушечника, обломок античной ручки - 1 шт., фрагменты керамики лепной с примесями ракушки, фрагменты керамики без минеральных примесей.

Штык 4. Основание штыка-73-75 см. Характер грунта меняется. В борту раскопа на глубине -60 см от поверхности отчетливо видна нижняя граница глубокой распашки. Ниже нее начинает проступать сероватый надматериковый слой (каштановый суглинок), в котором уже возможно различать коричневатые пятна перекопов. Профили раскопа отсняты по его бортам (рис. 26-27).

Постройка 2. В северо-западном квадрате раскопа 3 прослеживается аморфное пятно с коричневатым заполнением. В его пределах начал встречаться органический темный тлен. Расчистка пятна обнаруживает материковое дно и вертикальные стенки конструкции, которую можно воспринимать как часть ямы 12013 г., уходящей в борт раскопа. Ширина ее 70 см, длина 90 см. Глубина дна в материковом слое -117 см. Расчистка в пределах ямы 1 в северо-западной части ямы фиксирует следы органического тлена на глубине -114, -113 см. Здесь же найдены мелкие обломки керамики, 5 обломков камней и 4 обломка раковины. На глубине -83 см фиксируются обломки керамики охристого и черного цвета. Хорошо различимы примеси ракушки в тесте. Мелкие черепки отмечены на глубине - 106 см.

Обнаруженная ситуация создала необходимость прирезки к раскопу 3 с северо-запада с целью выхода на расчистку открываемой конструкции.

Прирезка осуществлена следующим образом. С северо-запада к линии А-Б 
раскопа 3 прирезан квадрат № 5 размером $2 \times 2$ м с углами Д, К, А, П. С востока к нему прирезан квадрат № 6 размером $2 \times 2$ м с углами К, Е, Ж, А. С запада к квадрату 1 раскопа 3 прирезан квадрат № 7 размером $2 \times 1,5$ м с углами П, А, И, 3.

Далее верхние плоскости этих квадратов начали опускать на глубину -73 см для выхода на уровень зачистки ситуации, частью которой является яма 1. Пройденные штыки находок не содержат. Зачистка площади выявила подпрямоугольный контур большой конструкции, отличаемой коричневатым заполнением от окружающего более светлого грунта.

Конструкция имеет западную границу (стенку) длиной 3,2 м, идущую с юга на север вдоль западного борта квадратов 5 и 7 (3-Д). В квадрате 7 прослежено продолжение стенки ямы 1 вдоль южной стенки этого квадрата. Общая длина этой линии - 2,2 м. В квадрате 5 отмечается углубление (яма 2) с неровными очертаниями, близкими к прямоугольнику размером примерно $1 \times 1$ м. Глубина дна ее - 119 см (рис. 24).

В квадрате 6 зафиксировано продолжение границы стенки ямы 1 , идущее с юга на север. В северо-восточном углу квадрата 6 прослеживается коричневатое пятно. Расчистка его дает частично входящую в площадь квадрата 6 новую яму № 3. Яма 3 явно впущена в расчищаемый объект и срезала его северо-восточный угол. Здесь прослежена часть ямы 3 , впущенная в рассматриваемую конструкцию.

В квадратах 5 и 6 выявлена северная граница исследуемой конструкции, идущая с запада на восток. Ее длина 3,4 м.

Дно зафиксированной конструкции находится в материке на глубинах -110 - -111 -114 м, не считая дна ямы 2. Оно не ровное.

В пределах ям 1 и 22013 г. найдены мелкие черепки лепной керамики светлокоричневого цвета и фрагмент охристой керамики - миски (без искусственных минеральных примесей). Общее число черепков более 20 шт.

Северо-восточный угол конструкции (и раскопа), как отмечалось выше, был прорезан ямой 3 (рис. 25-1) диной 1,8 м и ши- риной 1,20 м. Заполнение ямы 3 выделяется от расчищаемой конструкции мешаным коричневатым суглинком. Ее дно находится на глубине -118 - -122 см.

Внутри ямы 3 зафиксирована внутренняя яма 3а. Ее диаметр около 80 см. Глубина дна - -135 см (рис. 25-1). В пределах этой внутренней ямы на глубине -81, -123, -135 см найдены мелкие черепки лепной майкопской керамики (стенки) и черепки керамики без минеральных примесей. Яма 3 уходит в северный и восточный борта раскопа. Но мы не стали делать новую прирезку для ее полного исследования в связи с ограниченными ресурсами сил и времени.

В целом в результате раскопок получилась подпрямоугольная фигура строения, ориентированная по сторонам света (рис. 25-1). Его размеры 3,4×3,2 м. Дно открытого помещения неровное. В квадрате 5 оно имеет углубление до глубины -120, -119 см (так называемая яма 2). В квадрате 5 в пределах ямы 22013 г. встречен обломок зернотерки на глубине -82 см (рис. 25-2) и северо-восточнее от него развал черепков (миски черного цвета).

По раскопанному объекту возможно предположить, что мы столкнулись с заброшенной постройкой № 2. Ее ориентировка была связана со сторонами света. Вход в строение предполагался с юго-восточной стороны. Конструкция была обнаружена по пятну на глубине - 73 см, то есть на 13 см ниже уровня распашки и явно выше уровня материкового слоя. Глубина впущенной в грунт полуземлянки составляла около 40 см. (Перепад глубин - -73 - -136 см). Площадь строения равнялась 10 м².

Строение было заброшено. На глубине -80 - -82 см образовался «горизонт» находок из обломка каменной зернотерки и фрагментов керамики, зафиксированных именно на этом уровне. В северо-восточный угол заброшенной постройки врезалась яма 3.

Стратиграфия раскопа 3 будет рассмотрена ниже (рис. 26; рис. 27; рис. 28; рис. 29). После завершения работ по расчистке постройки 2 наступил этап работ по выявлению находок в площади пятна в квадрате АБВГ зоны Б (рис. 25-1). 
Погребение теленка. (Яма 42013 г.) Выход на контуры ямы 4 начался после того, как в юго-восточной части квадрата 3 АБВГ при зачистке на уровне материка начали проступать границы пятна, заполненного темным грунтом с массой беловатых включений глины-белоглазки (рис. 30). Эту часть раскопа 3 мы обозначили как зону Б (рис. 25-1). Было отмечено, что белесые включения сопровождали именно заполнение ямы и не прослеживались в материковом грунте. При дальнейшей расчистке на скальпель на глубине -120 см в пределах этой ямы были отмечены кости животного, создающие впечатление, что они сохраняют анатомическое положение. Вместе с ними были отмечены два камня, один из которых напоминал обломок зернотерки.

Дальнейшее исследование ситуации с ямой 4 было связано с прирезкой к квадрату 3 АБВГ с юга нового квадрата с углами Г1ВЛК. Его длина по линии С-Ю 2 м, по линии В-32,25 м. Опускание квадрата для исследования ситуации продолжалось до глубины -90 см, затем с горизонтальными зачистками - до глубины -109 см. В итоге были выявлены контуры ямы близкой к форме круга с диаметром 2,2 м (рис. 25-1; рис. 31; 32). Ее расчистка дала следующие результаты.

Практически в центре ямы находится часть скелета молодого теленка ${ }^{1}$ с небольшими проступающими рожками, положенного в заполнение на правый бок с ориентацией головой (мордой) к югу. Хорошо сохранились кости черепа, лопатка, передние конечности (но не копыта). Крестцовая часть скелета отсутствует.

Верх обнаружения костей теленка-126 см. Череп находится на глубине -124-128 см (рис. $31 ; 32 ; 33 ; 34 ; 35)$.

К юго-востоку от черепа теленка на глубине -131 - -127 см расчищены два позвонка крупного рогатого скота, под костями ребер теленка расположена крестцовая часть также крупного рогатого скота. К югу от костей скелета теленка зафиксированы отдельно лежащие кости ног этого животного на глубинах от -132 до -138 см.
Две небольшие кости животного встречены к востоку от скелета теленка в заполнении ямы.

В заполнении ямы 42013 г. найдено около 50 мелких фрагментов керамики (рис. 36). В основном это керамическая крошка от сосудов с минеральными примесями в тесте. Есть черепки с внешней черной поверхностью и красной внутренней поверхностью, есть фрагменты с обеими черными поверхностями. Три фрагмента керамики охристого цвета не содержат видимых на глаз микропримесей (рис. 36, 4-6).

Два фрагмента относятся к лепной керамике двустороннего черного цвета с видимыми на глаз примесями, скорее всего, ракушки. Оба фрагмента принадлежат к кухонной посуде, на одном черепке сохранились следы копоти (рис. 36, 9, 10). Черепки найдены к западу от ребер животного на глубине -140 см (в заполнении). Здесь же находились два фрагмента керамики черного цвета от лепного сосуда (рис. $36,7,8$ ).

К западу от скелета теленка на глубинах -126, -131, -136 см, несколько выше дна, зафиксированы также четыре мелких камня и обломок зернотерки (рис. 37). На дне ямы спорадически отмечались мелкие угольки. Их скопление прослежено под черепом животного на дне ямы, под заполнением.

После снятия костей животных и заполнения ямы было прочищено дно (рис. 38). Оно имеет ровную форму, несколько понижающееся ко дну. Глубина дна по центру ямы -149 см, под стенками - -141 см. С западной и восточной стороны отмечено расширение ямы на конус (рис. 26, 1).

В целом можно прийти к заключению, что наша фиксация контура ямы связана с глубинами -121 - -123 см. Эти глубины значительно ниже обнаружения входной ямы жилища 2 (-73 см).

Явно, что форма ямы 42013 г. в виде правильного круга была сооружена специально. Его размер вполне соответствует размерам погребения. Дно ямы подверглось обряду очищения! О чем свидетельствуют угольки на дне под первым слоем заполнения. Затем

\footnotetext{
${ }^{1}$ Определения к.г-м.н. зоолога В. С. Байгушевой, доцента Ростовского государственного университета.
} 
на дно ямы начали забрасывать землю. Туша теленка была не брошена в яму абстрактно, а положена на бок, на слой земли, строго в центр сооружения. Куда делась крестцовая часть туши - не известно. Ее в яме не было. Далее яма с животным была забросана заполнением, содержащим, на первый взгляд, обычный поселенческий мусор из культурного слоя, Случайно ли присутствие в яме крупного обломка зернотерки, как в захоронении человека? Ведь он был зафиксирован на одном уровне с костями животного на 10 см выше дна ямы!

Замечу по ходу рассуждений, что среди десятков (если не сотен) так называемых мусорных ям майкопских поселений нет ни одной ямы, содержащей целый череп животного или набор костей полного скелета in situ. Целый череп животного - это безусловный ритуал жертвоприношения, возможно, так же как и поломанная зернотерка.

Радиокарбонная дата погребения те-

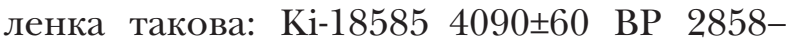
2499 ВС, то есть 29-25 вв. до Н. э.

Профиль южной стенки В-Г содержит слой распашки с глубиной до -60 см, надматериковый слой до глубины -90 см и материковый слой желтоватого суглинка. Юго-восточная часть профиля включает яму № 4, прорезавшую материковый слой. Глубина дна ямы по профилю -124 см. Западный край ямы входит в профиль наподобие подбоя. Заполнение ямы содержит многочисленные включения белесоватых пятен высолов и фрагмент лепной керамики. Размер ямы 4 по верхнему краю фиксации 220 см, по дну - 240 см (рис. 26, 1).

Профиль восточной стенки Б-В содержит слой распашки с глубиной до -60 см, надматериковый слой до глубины -70, -80 см. Переход к материковому слою желтоватого суглинка отмечен на глубине -90 см. В надматериковом слое изредка прослеживаются белесые высолы (рис. 26, 2).

Профиль западной стенки Г-А. На профиле помещен слой глубинной распашки, надматериковый слой до глубины -70 см, а также участок ямы 1 , которая выделяется коричневатым заполнением с белесыми высолами. Глубина дна ямы -120 см. Пере- ход к материковому слою находится на глубине -90 см (рис. 26, 3).

Профиль северной стенки А-Б содержит слой глубинной распашки с глубиной до -60 см, надматериковый слой до глубины $-70,-80$ см. В него включена часть ямы 1 с белесыми пятнами высолов. Глубина дна ямы -120 см. Материк находится на глубине -90 см.

Квадрат 2 после горизонтальной зачистки был понижен до глубины - 100 см с целю выявления пятен на этой площади. Часть заполнения квадрата оставлена как маркер глубины раскопки ситуации с ямой 1 (рис. 26, 4).

\section{Профили дополнительно прирезаннъх квадратов контура ИЗДЕЖ}

Профиль ЕЖ. Слой распашки имеет глубину -60 см. На глубинах -60 - -90 см прослеживается сероватый культурный слой. Переход к материковому желтому суглинку фиксируется с глубины -90 см (рис. 27, 1).

Профиль ДЕ. Слой распашки имеет глубину -60 см. На глубинах -60 - -90 см прослеживается сероватый культурный слой. Переход к материковому желтому суглинку фиксируется с глубины -90 см. В профиль входит разрез ямы 3 с ее внутренней ямой $3 \mathrm{a}$ (рис. 27, 2).

Профиль ИЗ. Слой распашки имеет глубину -60 см. На глубинах -60--90 см прослеживается сероватый культурный слой. Переход к материковому желтому суглинку фиксируется с глубины -90 см (рис. 27, 3).

Профиль ЗД. Слой распашки имеет глубину -60 см. На глубинах -60--90 см прослеживается сероватый культурный слой. Переход к материковому желтому суглинку фиксируется с глубины -90 см (рис. 27, 4).

Разрезы раскопа 12013 г. Для раскопа 1 2013 г. сделано три разреза, отражающих его особенности.

Разрез $X-У$ проходит в направлении юг - север через середину квадратов 1 и 4. В него попадают ямы $1,2,3,3$ а (рис. 28,1 ).

Разрез Б-П проходит в направлении восток - запад по северной стенке квадратов 1-2 и квадрата 7. В него включены ямы 1 и 2 (рис. 28, 2).

Разрез Р-C располагается по линии Ю-С в квадратах 5 и 7. В него входят ямы 1 и 2 (рис. 28, 3). 
Общие положения, отраженные слоями раскопа 12013 г., таковы. Внешняя поверхность квадрата была распахана. Она практически ровная с небольшими перепадами высот. Слой глубокой распашки достигает 60 см во всех профилях. Он представлен комковатой каштановой почвой, обозначаемой как каштановые черноземы Таманского полуострова. Ниже залегает плотный слой суглинка серого цвета, который можно назвать надматериковым слоем и в тоже время культурным слоем. Низ этого слоя находится на глубине около 90 см от поверхности с некоторыми вариациями. Верх культурного слоя разбит распашкой и точно не улавливается. Контакт надматерикового слоя с материковым слоем прорезан многочисленными ходами землероев. Материковый суглинок выделяется своим желтоватым цветом. В нем лишь изредка встречаются вкрапления карбонатов, зато в изобилии отмечаются крупные белесые высолы размером до 1 см в перемешанном заполнении ям.

\section{Раскоп 42013 г.}

Постройка 3. Раскоп 42013 г. (он же шурф 42013 г.) находится напротив столба 7 поблизости от раскопа 22012 г. Координаты раскопа 4 N 45 10' 48.5' E $036^{\circ} 37^{\prime}$ 58.3'. Размеры раскопа 42013 г. 4,70×4 м. Раскоп 42013 г. был ориентирован длинными стенками по линии 3-В. Углы раскопа получили обозначения А, Б, В, Г. Привязка угла Г (юго-западного) к столбу № 7 на север 22,50 м, на запад 8,70 м. Глубина отмеряется от репера у основания столба 7. Репер столба 7 на 10 см выше репера у основания столба 6 . Точка угла A +6 см, угла Б - 0, угла В -7 см, угла Г +10 см. Площадь раскопа подразделена на 4 условных квадрата. Угол А - квадрат 1, угол Б - квадрат 2, угол В - квадрат 3, угол Г - квадрат 4 (рис. 39, б).

Поверхность раскопа 4 распахана. Глубина распашки достигает около 40 см. В связи с этим два первых штыка объединены в один блок раскопок.

Находки первых двух штыков составляют мелкие черепки лепной керамики с примесями и охристой керамики без минеральных примесей. Всего около 34 шт.
На третьем штыке, на глубине -54 - -58 см от поверхности (репера раскопа в углу Г) в центре раскопа появились крупные камни-ракушечники по форме напоминающие фрагменты зернотерок (рис. 39, 3, 4). В квадрате 3 также стали встречаться черепки, кости животных и камни (рис. 39, 2), поэтому была предпринята общая зачистка площади.

Зачистка площади выявила два скопления камней и керамики. Скопление 1 занимает центральную часть раскопа, скопление 2 - квадрат 3 (юго-восточную часть раскопа).

В скопление 1 входят три плоских крупных камня-ракушечника размером 20× $14 \times 3$ см, $14 \times 14 \times 5$ см, $17 \times 14 \times 8$ см, которые можно принять как фрагменты зернотерок (рис. 39, 4). Помимо них расчищены еще восемь более мелких камней-ракушечников аморфных форм. Среди камней встречаются черепки лепной керамики, обломок раковины гребешка, мелкие горелые кости. Площадь скопления 1 составляет около 1,5×1,3 м.

В скоплении 2 зафиксированы фрагменты керамики, кости животных, створки раковины устрицы и небольшие камни. Скопление 2 занимает площадь $1,4 \times 0,7$ м. Глубина находок скопления $2--58--70$ см.

На уровне фиксации скоплений 1 и 2 четких пятен ям не фиксировалось. Однако явно оба этих скопления перекрывали некую скрытую в земле площадь, конкретизация которой произошла ниже.

После снятия находок скоплений 1 и 2 была проведена зачистка площади. Она выявила пятно темного грунта в зоне скопления 1 (рис. 39, 5). Глубина фиксации пятна $-77--73$ см. Пятно имеет эллипсовидную форму, ориентировано с юго-запада на северо-восток. Диаметры пятна $120 \times 100$ см (рис. 39, 6; рис. 40). Зафиксированное пятно оказалось ямой 1 в раскопе 42013 г.

Зачистка раскопа на глубине обнаружила пятна ямы 1 (-71 см), а также выявила находки керамики и камней. Керамика была представлена мелким боем стенок лепной керамики с минеральными примесями и отдельными мелкими фрагментами керамики без минеральных примесей. Наибольшая их густота связана с квадратом 3 раскопа 2 (около 
22 шт.). В квадрате отмечено только четыре фрагмента, в квадрате 1-один фрагмент, в квадрате 4-четыре фрагмента. Никаких костей не было зафиксировано (рис. 39, 6; рис. 40). Проведенная зачистка показала, что культурный слой вне контура ямы 1 , как места древней постройки, может быть насыщен сгустками мелкой керамической крошки и вовсе не насыщен костями животных.

Далее была проведена выемка грунта из заполнения ямы 1 и зачистка поверхности раскопа к югу и юго-востоку от ямы 1 на глубинах $-75,-108$ см. (Контур пятна остался на прежнем уровне - -75 см, чтобы не потерять последний).

В пределах пятна выявленной ранее ямы 1 было обнаружено ее дно. Оно понижалось с севера на юг до глубины - 108 см. В южной части ямы на глубине -108 см были расчищены фрагменты керамики и длинные кости животных, круглый плоский окатанный камень с отверстиями естественного происхождения, обожженное на огне копыто мелкого рогатого животного (рис. 41).

Зачистка площади раскопа к югу и юговостоку от ямы 1 была проведена на уровне -99 см, -108 см, практически на верхнем уровне слоя материкового грунта. Она зафиксировала границу темного пятна, примыкающего к выявленной яме 1 с юго-востока. С запада граница этого пятна была поймана только на глубине -99 см (рис. 41).

С юга граница пятна подошла вплотную к стенке раскопа. На глубине -99 см граница пятна состыковалась со стенками ямы 1 , выявленной на уровне -75 см ямы А (рис. 42; рис. 43).

В итоге была очерчена площадь, получившая название ямы 2, вплотную примыкавшая к яме 1. Яма 2 была заполненной находками. Ее можно представить вместе с ямой 1 , как постройка 3 , от которой сохранилась основная яма 2 с входом - ямой 1 (рис. 41 ; рис. 42; рис. 43).

Открытая конструкция может быть интерпретирована как полуземлянка. Вход в нее был устроен с северо-запада. Размеры полуземлянки, судя по ее границам, составляли в длину по линии С3-ЮВ - 274 см, по линии ЮЗ-СВ - 172 см. Причины, по которым зона входа обозначилась на глубине -75 см как отдельное пятно, могут быть неоднозначны. Не будем забывать, раскопки проходили в зоне культурного слоя, а здесь, как и в насыпи кургана, пятна могут «не читаться» или проступать неравномерно.

При расчистке заполнения строения найдены различные камни, многочисленные фрагменты лепной и майкопской керамики без минеральных примесей, кости животных, рыб, раковины. Некоторые кости животных обожжены.

Камни. Среди камней можно отметить три небольших гальки длиной 6-8 см (рис. 44, 1-3), небольшие, не окатанные камни того же размера (рис. 44, 4-6), зеленый камень длиной 12 см (рис. 44, 7), осколки камней коричневатого цвета (рис. 44, 9, 10), обломки от зернотерок из пористого песчаника (рис. 44, 8, 11).

В верхней яме раскопа 22013 г. зафиксирован окатанный камень овальной формы с четырьмя отверстиями естественного происхождения. (Такие камни встречаются в прибрежной полосе) (рис. 45, 9). Зафиксирован отпечаток спекшейся обожженной земли наподобие турлука с отпечатками тонких прутиков.

Во входной яме постройки и в самой постройке было расчищено большое количество фрагментов керамики. Особо выделяются обломки крупного сосуда (рис. 45, 17; рис. 46) с высоким горлом и ручкой-петелькой (рис. 46, 3). Они позволяют реконструировать форму как закрытую емкость с горлом высотой 5 см, диаметром венчика 18 см, сильно уплощенным овоидным туловом с диаметром около 60 см и с высотой тулова около 30 см (рис. 47, 1).

Толщина стенок тулова 1 см. На верхнюю часть тулова были поставлены петлевидные ручки с отверстием $2 \times 1,5$ см. Сохранилась одна из них. Сколько было всего ручек на сосуде - неизвестно (возможно, две). Под горловиной сосуда четко видна бороздка, выполненная механическим вращением заготовки на поворотном столике. Внешняя поверхность сосуда заглажена. На ней видны охристые (красноватые) пятна в виде размытых разводов (рис. 46,$1 ; 47,1$ ). 
Таблича 2

\section{Радиокарбонные определения комплекса находок жилища 3}

\begin{tabular}{|c|l|l|c|c|c|}
\hline № & \multicolumn{1}{|c|}{ Объект } & \multicolumn{1}{|c|}{ Шифр } & BP & BC 68\% & \multicolumn{1}{|c|}{ Примечание } \\
\hline & $\begin{array}{l}2013 \text { г. Раскоп } 4 . \\
\text { Кость животного }\end{array}$ & Ki-18584 & $4510 \pm 60$ & $3355-3035$ & Постройка 3 \\
\hline $\begin{array}{l}2013 \text { г. Раскоп } 4 . \\
\text { Кость животного }\end{array}$ & $\begin{array}{l}\text { Ki-18168 } \\
\text { Кост г. Раскоп } 4 . \\
\text { Кость животного }\end{array}$ & Ki-18589 & $4470 \pm 80$ & $3331-3123$ & Постройка 3 \\
\hline
\end{tabular}

Остальные сосуды представляют собой бой керамики черного и охристого тонов числом около 120 шт. (рис. 48; 49). Среди них есть фрагмент плоского дна крупного сосуда (рис. 47, 2) с минеральными примесями в формовочной массе; много обломков лепных сосудов черного цвета с минеральными примесями и примесями ракушки, а также без минеральных примесей охристого цвета (рис. 50). Есть крупный фрагмент $(15 \times 10 \mathrm{~cm})$ дна от очень большого плоскодонного сосуда с тестом без минеральных примесей (рис. 51, 1).

Отмечено скопление ракушек-устриц 65 шт., лежащих кучкой у южной стенки (рис. 52, 5-42). Там же найден камень-галька (рис. 52, 4) и обломки небольших камней (рис. 52, 1-3).

Особо в коллекции находок из постройки 3 выделяются три черепка с крашеной полосами поверхностью (рис. 53, 1, 2, 3). Они отмечены на фрагментах сосуда с тестом без минеральных примесей. Среди них есть фрагмент миски с тестом без примесей охристого цвета и двумя полосами, нанесенными красной краской на внутреннюю часть венчика (рис. 53, 2).

Некоторые фрагменты мисок из теста без минеральных примесей позволяют составить представление о профилях венчиков керамики (форма венчика № 17-19 по классификации С.Н. Кореневского) (Кореневский, 2004. С. 22-41) (рис. 54, 2-4) и миски с минеральными примесями и с загнутым внутрь венчиком (рис. 54,5 ).

В заполнении строения у западной стенки отмечена головка глиняного конуса с отверстием - приставки к очагу характерного типа для псекупского варианта $\mathrm{MHO}$ (Кореневский, 2004. С. 53, 54). Длина фрагмента - 8 см. Сохранность фрагмента очень плохая, практически он не обожжен (рис. 54, 1). Найден также фрагмент маленькой миски с минеральными примесями диаметром около 3 см (рис. 55, 1).

Створки раковин представлены в основном раковинами-устрицами (рис. 55, 2).

Кости в жилище 3 (рис. 55, 3) лежали без особого порядка. По предварительному определению их В.С. Байгушевой, в коллекции имеются останки коровы очень крупной и нормальной, лошади 3,5-4 года, кости рыб, раковины, кости птиц, мелкого рогатого скота (коза/овца).

В целом общий контур постройки в раскопе выглядит как овал, ориентированный с юго-востока на северо-запад $3 \times 2$ м (рис. 56).

Профили раскопа 4 (рис. 57, 58) достаточно однообразны. Слой пахоты достигает 40 см, ниже находится культурный слой. Переход к материку наблюдается на глубинах около 90 см. В профиле А-Б отмечен крупный фрагмент охристой миски с тестом без минеральных примесей. Глубина залегания фрагмента около 30 см ниже поверхности. Скорей всего, эта глубина показывает возможный верхний уровень культурного слоя, разбитого распашкой. Но такой вывод требует подкрепления новыми материалами.

Радиокарбонные определения комплекса находок постройки 3 представлены в таблице 2.

Всего получены три даты по костям животным. Их интервалы близки. Это 34-31 вв. до н. э.; 34-32 вв. до н. э.; 34-30 вв. до н. э. 


\section{ГЛАВА 4. Ход работ. 2014 год}

В задачу работ 2014 г. входили раскопки двух шурфов с целью обнаружить очередное жилище на поселении и определить северную границу поселения.

Реперная точка отсчета для работ 2014 г. была выбрана как столб № 7 электропередачи на проселочной дороге. Его привязка N $45^{\circ} 10.801$ ' E $036^{\circ} 30.050^{\prime}$. Квадрат 1 раскопа 5 был разбит в 80 м на север от столба 7. Он имеет размер $2 \times 2$ м. Ориентировка широтная. Реперная отметка N $45^{\circ} 10.837^{\prime}$ Е $036^{\circ} 38.017$ ' (северо-восточный угол).

Постройка 4 (начало работ). Раскоп 5 2014 г. (или квадрат 12014 г) имеет следующие нивелировочные отметки. Угол А (юговосточный $)$ - 0 (+82 см от репера столба 7 , далее все отметки от репера можно легко пересчитать), угол Б (северо-восточный) +1 см, угол В (северо-западный) +3 см, угол $\Gamma$ (юго-западный $)+3$ см. Удаление грунта начато штыковой лопатой с шагом опускания 25-30 см (размер штыка) (рис. 58; 59). Раскоп 5 вырыт до глубины -130/135 м от поверхности пахоты. Вначале в слое пахоты раскопки велись по штыкам (1, 2 штыки) без горизонтальных зачисток при отсутствии находок.

Первые находки представлены в зоне культурного слоя в виде четырех небольших фрагментов керамики, зуба и обломка кости (ребра) животного. Эти находки были зафиксированы на основании 3 штыка. Другие находки начали встречаться на глубине - 0,8 м в северо-восточном углу квадрата (рис. 59, 1). Один фрагмент из этого скопления черного цвета, насыщен примесями ракушки. Второй фрагмент имеет темную наружную и внутреннюю поверхности (аналоги ему будут встречены ниже) и тесто без искусственных минеральных примесей. Есть также черепок без минеральных примесей красного цвета и керамическая крошка.

На глубине -103 см была сделана зачистка дна квадрата. Она на этой глубине не вы- явила пятна ямы. Но в северо-восточном углу начал проступать венчик сосуда и у восточной стенки появилась кость животного (рис. 59, 2; рис. 60). Только расчистка на глубине -126/131 см несколько прояснила ситуацию по залеганию находок, которые начали концентрироваться в северо-восточной части квадрата (рис. $59 ; 60$ ). На глубине -126 м в центре скопления найдены конкреции, похожие на угли. Далее расчистка скопления выявила крупный венчик лепного сосуда, отбойник на гальке, черепки с минеральными примесям в тесте и без них, кости животных, скопление более 60 створок раковин-устриц и раковин-гребешок (рис. 61-64). Площадь квадрата размером примерно 40×40 см, примыкающая к углу Б, была забита золой (массой серого пепла).

Скопление находок было зафиксировано и затем снято.

Снова на глубине -139 см (по уровню желтого материкового суглинка) была сделана зачистка площади. Теперь в слое стерильного материка четко стало проступать пятно конструкции темно-серого цвета. Длина пятна по линии С-Ю - 122 см, ширина по линии 3-В - 62 см. Пятно несколько сужается к югу от северной стенки квадрата и в конечном итоге образует южную стенку трапециевидной фигуры. Южный контур трапеции у восточной стенки квадрата разворачивается на север и входит в восточный борт квадрата. Никаких находок на этом уровне в зоне пятна не было.

Выемка грунта из заполнения ямы дала находки нескольких костей крупного рогатого скота, несколько черепков и крупный фрагмент керамики и камень.

Дно расчищаемой ямы проступило на глубине -146 см. Оно относительно ровное и вырыто в слое материка на 7 см.

Ситуация с раскопками в раскопе 5 2014 г. наводила на мысль о том, что мы 
попали на часть ямы, возможно, строенияполуземлянки. Для ее полноценного исследования требовалась прирезка несколькими квадратами 2×2 м с севера и востока. Однако возможности сделать такую работу в 2014 г. у меня не было. Поэтому было принято решение о консервации раскопа 52014 г. до продолжения раскопок в этом месте в 2015 г.

Стратиграфия квадрата 12014 г. была одинакова для всех его четырех сторон. Слой распашки достигал 0,59-0,6 м. Далее залегал палевый рыхлый суглинок. На глубине -0,9/-1 м начинался переход к слою, насыщенному карбонатной (белесой) крошкой. Цвет этого слоя более темный, коричневатый. Низ карбонатного слоя находится на глубине -117 см. На глубине -117/-132 см располагался темноватый плотный суглинок без карбонатов. На глубине -138 см и ниже фиксируется слой плотного желтого суглинка материка. Все слои ниже уровня пахоты прорезаны многочисленными ходами червей, отмечаются также кротовины.

Находки в раскопе 52014 г. представлены керамикой 1 и 2 классов, обломком очажной приставки, изделиями из камня (рис. 61-64).

Черепков от сосудов 1 класса найдено девять (рис. 62). Среди них есть черепки охристого цвета. Один фрагмент несет следы окраски алого тона на внутренней стороне (рис. 62, б). Один фрагмент имеет блестящий черный цвет, другой блестящий серый цвет (рис. 62, 7, 9). Один фрагмент сохранил две полосы красного цвета - след пролощенности (рис. 62, 5). Очень интересен обломок миски с т-образным венчиком охристого цвета со следами от использования поворотного механического устройства (рис. 63, 1, 2).

Встречены также обломки сосудов 2 класса, лепных с минеральными примесями. В их число входит венчик крупного сосуда диметром 37 см и высотой 7 см (рис. 61, 1; 63, 2) черного цвета с крупными порами (признаком органики) и примесями мелкодробленой раковины в тесте. Внешняя поверхность его заглажена и подлощена. Примечательно, что перед венчиком с наружной стороны имеется желоб, внешняя поверхность сосуда обмазана слоем глины. Есть также фрагмент лепной миски черного цвета (рис. 61, 2).

Керамика из квадрата 1 представлена в основном боем стенок толщиной 5-7 мм. Размеры черепков разные от $3 \times 4$ см до $5 \times 7$ см. Общее число фрагментов до 45 шт. (рис. 64, 1-9, 12).

Найден обломок основания приочажной приставки (рис. 61, 3) псекупского типа.

В скопление находок также входил маленький отбойник на гальке длиной 5,5 см (рис. 61, 4; рис. 64, 10) и скол обсидиана (рис. 61, 5; рис. 64, 11).

Скопление раковин, положенных кучкой, включает 63 находки. В основном это раковины-устрицы и раковины-гребешок (рис. 60).

С северной стенки раскопа (квадрата 1 2014 г.) были отобраны пробы для палинологического анализа (рис. 65-1).

\section{Раскоп 62014 г.}

Раскоп 6 (квадрат 22014 г.) вырыт на расстоянии 180 м от реперного столба на север и в 80 м от квадрата 12014 г. Координаты шурфа N $45^{\circ} 10.841^{\prime}$ E $036^{\circ}$ 024' (северо-восточный угол) (рис. 66, 1). Квадрат раскопан на глубину 5 штыков до глубины -130 см от поверхности с зачисткой на 4 и 5 штыках (рис. 66). Грунт прорезан норами землероев и ходами червей. Находок практически нет. Лишь на третьем штыке встречен охристый майкопский черепок (фрагмент стенки $3 \times 4$ см). Небольшой черепок $(2 \times 3$ см) с примесями ракушки зафиксирован на 4-м штыке.

Общая стратиграфия шурфа 6 такова. Материк - плотный желтоватый суглинок - фиксируется с глубины 130 см. На глубине -120 намечается переход к карбонатному слою. Низ карбонатного слоя находится на глубине -120 см. На глубине -90 - -100 см отмечен переход от карбонатного слоя к докарбонатным отложениям палевого суглинка, к так называемому культурному слою. На глубине -60 см докарбонатный слой палевого суглинка разбит слоем глубокой распашки.

Пробы для палинологического анализа отобраны из северной стенки квадрата 2 2014 г. (рис. 66). 
Таблича 3

Колонка проб для палинологического анализа из шурфа 62014 г.

\begin{tabular}{|c|c|c|c|}
\hline № & Глубина & Слой & Комментарии \\
\hline 1 & 130 & Материк & палевый суглинок плотный \\
\hline 2 & 121 & $\begin{array}{l}\text { Верх материка - низ } \\
\text { карбонатного слоя }\end{array}$ & \\
\hline 3 & 105 & Верх карбонатного слоя & $\begin{array}{l}\text { Коричневатый суглинок, насыщенный } \\
\text { включениями карбонатов. Найден } \\
\text { фрагмент керамики }\end{array}$ \\
\hline 4 & 99 & $\begin{array}{l}\text { Низ культурного } \\
\text { докарбонатного слоя }\end{array}$ & $\begin{array}{l}\text { Коричневатый суглинок, насыщенный } \\
\text { включениями карбонатов }\end{array}$ \\
\hline 5 & 91 & $\begin{array}{l}\text { Верх культурного } \\
\text { докарбонатного слоя }\end{array}$ & Суглинок палевого цвета, рыхлый \\
\hline 6 & 84 & $\begin{array}{l}\text { Культурный докарбонатный } \\
\text { слой }\end{array}$ & « \\
\hline 7 & 66 & $\begin{array}{l}\text { Культурный докарбонатный } \\
\text { слой }\end{array}$ & $\ll$ \\
\hline 8 & 62 & $\begin{array}{l}\text { Контакт слоя распашки } \\
\text { и культурного } \\
\text { докарбонатного слоя }\end{array}$ & « \\
\hline
\end{tabular}




\section{ГЛАВА 5. Ход работ. 2015 год}

Раскоп 5 2014/2015 гг. (продолжение работ; квадраты 1 2014/2015 г. и квадраты 2-5 2015 г.).

Первый этап работ. Цели работ 2015 г. формулировались как продолжение раскопок 2014 г. в квадрате 1, в котором была обнаружена часть ямы, заполненной керамикой и костями. В 2014 г. квадрат 1 был засыпан. Первым шагом работ 2015 г. стал поиск места исследований, поведенных в предыдущем году. Ориентиры квадрата 1 были таковы. Азимут 340 градусов, расстояние от столба № 7 - 79,30 м. Привязка по GPS N 45', 10,837' Е 036 38,024'. Проверка прибора показала его ошибку в долях секунд. Поэтому критериями поиска стал только азимут, взятый по буссоли, и расстояние, определяемое по рулетке. Новые данные по GPS таковы. Реперный столб № 7 N $45^{\circ}$ 10' 47,8" E $036^{\circ} 38^{\prime}$ 01,6". Место раскопок ямы-полуземлянки или квадрата 12014 г. № 7 N $45^{\circ}$ 10' 50”, , E $036^{\circ} 38^{\prime}$ 02,3”'.

На искомом месте были заложены два квадрата $2 \times 2$ м с ориентацией по линии запад - восток. Западный квадрат получил № 12015 г., восточный - № 22015 г. Раскопки в квадрате 12015 г. на 2 штыке выявили след искомого квадрата 12014 г., как часть прямоугольной ямы, забросанной мешаным грунтом. Далее с северной стороны квадратов 1 и 2 была намечена линия квадратов $2 \times 2$ м. Квадраты получили номера $3,4,5$. Квадраты 4 и 5 находились напротив квадратов 1 и 2. Между квадратами 1 и 2 и квадратами $3,4,5$ была оставлена бровка шириной 50 см (рис. 67). Так образовался раскоп 12015 г.

Репер отсчета глубин находится у основания столба № 7 линии электропередачи. Репер 0 раскопа 12015 г. (Р0) установлен в юго-западном углу квадрата 1. Его отметка +91 см от репера у столба 7.

Второй этап работ ставил задачу выявить в квадрате 12014 г. участок раскопан- ной ямы и выйти на пятно предполагаемой еще не раскопанной части конструкции. По данным 2014 г. находки в зоне ямы начали попадаться с глубины -80 см от репера раскопа. Стратиграфия квадрата была такова. Пахотный слой достигал 60 см. Ниже располагался надкарбонатный слой, в котором уже встречались находки. Уровень залегания карбонатов находился на глубине -90 - -100 м. Дно ямы квадрата 12014 г. было отмечено на глубине -146 - -153 см.

Поиск конструкции, с которой была бы связана яма 2014 г., начался с раскопок в квадратах 3-5.

Первый штык раскопки квадратов 3-5 достиг глубины -20 - -27 см. Его грунт представляет пахотный слой. Находок в нем нет.

Второй штъљ в квадратах 3-5 также связан с пахотным слоем. В квадрате 4 найден венчик охристой миски. Глубина основания 2 штыка -0,54 - -0,61 см.

Третий штык в квадратах 3-5 продолжал раскопки в пахотном слое. Его основание находится на глубинах -72 см, -80 см. Находок нет.

Четвертый штык в квадратах 3-5 дал основание -85, -93, -94, -96 см от Р0. На этих глубинах найдены четыре фрагмента стенки лепного сосуда бурого цвета с мелкими примесями ракушки.

Зачистка дна квадратов показывала, что оно совпадает с уровнем материкового суглинка с включениями карбонатов. Карбонаты проступают слабо, и мы находимся на переходе к карбонатному слою материка. Особое внимание было обращено на сегментовидное пятно мешаного темного грунта, выступающее к северу из борта бровки. Но что это такое, понять было в тот момент невозможно. Ясно было одно, для выяснения ситуации необходимо было опускаться на большую глубину горизонтальными зачистками до обнаружения границ искомой конструкции. 
Верхняя яма. На глубине -77 - -88 см в северо-западном углу квадрата 22015 г. начали встречаться кости животных и керамика. Это скопление совпадает со скоплением костей и черепков на глубине -80 см, обнаруженном в северо-восточном углу квадрата 1 2014 г. Скорей всего, это была яма, вырытая в культурном слое. Ее верхний уровень фиксации отмечен на глубине -77 см, нижний - на глубине -97 см (рис. 68).

На глубине -104 - -109 продолжало фиксироваться скопление находок в северо-западном углу квадрата 2, расширяясь в зону бровки между квадратами 1, 2 и квадратами 4, 5. В этом скоплении были найдены три фрагмента керамики 1 класса, три фрагмента черепков от лепных сосудов класса 2, семь костей животных, одна раковина.

На глубине -110 см была сделана полная зачистка квадратов 1 и 2. В квадрате 1 был вынут весь грунт заполнения ямы 2014 г. и восстановлены ее контуры с зафиксированным ранее углублением, забитым находками керамики и костей.

Пятно заполнения строения стало фиксироваться как зона более темного грунта на фоне светло-желтого материка. Оно прослеживалось в зоне бровки Г-З-К-Е и в квадрате 2 (рис. 69, 1, 2).

Постройка 4 (продолжение работ 2015 г.) Третий этап работ. Расчистка заполнения строения происходила с помощью соответствующих инструментов для этого вида операций. Чертеж и фотофиксация находок произведены на глубинах -119 - -139 см. В северной части расчищаемой площади был встречены необработанные камни размером 10-15 см в поперечнике (рис. 69, 2). В разных местах заполнения попадались черепки керамики 1 класса (рис. 70, 1) и 2 класса (рис. 70, 2; рис. 71), кости животных, птиц, сколы кремня. В северной части расчищаемого пятна были отмечены обширные сгустки серого пепла (рис. 72-1). В зоне пересечения квадратов 1, 2, 3, 4 на глубине -135, -136 см были зафиксированы камни - ракушечник размером 20-30 см без особых очертаний форм - и черепки охристого сосуда (рис. 72-2).

После фиксации этот пласт находок был снят. Следующий этап фиксации был связан с глубинами -139 - -155 см. На этих глубинах находок стало встречаться меньше, хотя их качественный набор существенно не изменился. Так, фрагментов сосудов 1 класса красного цвета найдено пять, коричневого цвета-два. Фрагментов сосудов 2 класса зафиксировано в количестве 44 , костей животных и птиц - 40, раковин устриц - 19, раковин-гребешок - 1 шт.

Особое внимание привлекают кладки из небольших необработанных камней. Одно скопление находится на прослойке, выше дна конструкции (рис. 72-2; 73). Другое скопление выявлено в юго-восточном углу квадрата 2. Верхний уровень камней находится на глубинах -139 см (рис. 74; рис. 75). Камни стоят в вертикальном положении основаниями на глубине -149, -152, -154 см. От дна их отделяет тонкая прослойка земли.

К северу от каменной кладки на глубине -155 см на дне ямы зафиксировано пятно с включениями углей. Размеры пятна $40 \times 40$ см. Следов интенсивного прокала земли в зоне углистых включений отмечено не было. Все пространство ямы к северу от этого скопления углей было заполнено слоем земли вперемешку с серым пеплом (рис. 75). Дно конструкции фиксируется на глубине $-153,-155$ см.

Стратиграфия раскопа представлена северными профилями квадратов 3-5 по линии Л-П, западным профилем Л-О для квадрата 3 (линия север-юг), восточным профилем П-К для квадрата 5 (рис. 67; рис. 76). Стратиграфия квадратов 1 и 2 с раскопанной конструкцией ямы комплекса 4 отражена профилем 3-К и профилем Г-Е. Стратиграфия остальных профилей стандартна и никаких включений не содержит.

Северный профиль квадратов 3-5 Л-П (рис. 67,1 )

Слой распашки достигает 60 см. Ниже располагается надкарбонатный слой на глубинах -60 - -80/90 см. На глубине $-90--100$ и ниже идет карбонатный слой материкового суглинка.

\section{Западньй профиль квадрата 3 Л-О}

Он повторяет данные предыдущего профиля. Слой распашки достигает 60 см. Ниже 
располагается надкарбонатный слой на глубинах -60 - -80/90 см. На глубине -90 - -100 см и ниже идет карбонатный слой материкового суглинка.

Восточный профиль квадрата 5 П-К. Слой распашки достигает 60 см. Ниже располагается надкарбонатный слой на глубинах -60 $-80 / 90$ см. На глубине $-90,-100$ см и ниже идет карбонатный слой материкового суглинка.

Северный профиль 3-К квадратов 1 и 2 (реконструкиия). Слой распашки достигает 60 см. Ниже располагается надкарбонатный слой на глубинах $-60--80 / 90$ см. На глубине $-90--100$ и ниже идет карбонатный слой материкового суглинка. В профиль вписана северная часть ямы-полуземлянки. Ширина ямы по профилю 1 м. Глубина -70 см. Верх ямы ловится на глубинах -80 см.

Южный профиль Г-Е квадратов (реконструкиия).

Слой распашки достигает 60 см. Ниже располагается надкарбонатный слой на глубинах -60 - -80/90 см. На глубине -90 - -100 см и ниже идет карбонатный слой материкового суглинка. Профиль прорезан ниже слоя распашки контуром ямы-полуземлянки. Ширина ямы 180 см, глубина -70 см (рис. 76).

Выводы. Обнаруженная конструкция представляет собой яму двухчастной формы. Ее западная часть имеет прямую стенку. Восточная часть ямы придерживается контуров овала. Яма ориентирована по длинным осям с юго-востока на северо-запад и с юго-запада на северо-восток. Размеры ее по этим осям соответственно 185-180 см.

Уровень фиксации верхних стенок ямы связан с глубинами около -80 см. Но более определенно ее контур читается на глубинах -110 см, то есть в материковом слое.

Яма имеет заполнение, состоящее из брошенных в нее обломков сосудов, костей животных, раковин. Наиболее интенсивно находки сосредоточены на глубинах -119 - -136 см. Ниже их число заметно уменышается.

Порядок заполнения ямы выглядит таким образом. Вначале на дне восточной части ямы образовалось пятно 40-50 см ${ }^{2}$ со следами горения. Большой огонь в яме не разводили, так как следов прокала и обжига земли нет. Отмечены были только три небольших кусочка докрасна прокаленной земли и несколько горелых костей.

Далее на дне была размещена подушка из грунта толщиной около 5 см. На ней в юго-восточной части ямы была сооружена кладка из вертикально стоящих необработанных камней. Камни также были размещены в центре ямы. Образовалась как бы загородка, делящая пространство ямы на две части: восточную, где находилось углистое пятно, и западную, которая включала часть ямы, раскопанную в 2014 г., с прямой стенкой. Затем яму стали интенсивно забрасывать обломками керамики и обломками костей животных. Многие кости были раздроблены. Они явно были связаны с трапезой. Наиболее густой слой заброса костей находился на глубинах -119--136 см, то есть существенно выше дна ямы. Вместе с черепками и костями животных в яму бросали пищевые отходы в виде раковин устриц и раковин гребешков. В яму так же было брошено большое количество пепла. Его обширная масса (рис. 72-2) никак не связывается со слабым прокалом на дне. Видимо, в яму сбросили продукты горения от источника огня где-то на стороне.

Выше уровня -119 см находок немного. Самые верхние из них находятся на уровне -77 см. Возможно, они относятся к некой малой яме (скопление 1), которая врезалась в слой уже засыпанной ямы полуземлянки. Эта верхняя яма находилась на пересечении квадратов шурфа 52014 г. (кв. 12014 г.) и кв. 22015 г. (рис. 68).

Раскопанный объект возможно является постройкой-полуземлянкой. Ее финальный этап существования был связан с забрасыванием ее отходами быта, пищи, продуктов горения в виде пепла и прожженных костей животных, которые сгорели где-то на стороне. Такой случай позволяет ставить вопрос об особых ритуалах финальной консервации обитаемого ранее строения. В 2018 г. такой вывод полностью подтвердился при раскопках поселения Чекон А. И. Юдиным (Кореневский, Юдин, 2019).

Общая характеристика находок в раскопе 52015 г., связанных с постройкой 4, такова. 
Фрагментов керамики 1 класса найдено 23 (19 - красного цвета, 1 - черного цвета) (рис. 77, 1-4; 77, 5). Толщина стенок сосудов 1 класса около 50 мм. Из венчиков сосудов разных форм доминируют венчики мисок (рис. 78).

Среди керамики 1 класса интересны фрагменты с раскраской. Перечислим их ниже.

Фрагмент венчика со следами полос темно-коричневого цвета (рис. 79,1$)$.

Фрагмент стенки охристого сосуда. На внутренней стороне проведена полоса красной краской (рис. 80).

Фрагмент венчика крупного сосуда, видимо, большой миски. На венчике и на внутренней стороне черепка прослеживаются полосы малинового цвета. Полосы являются частями дуги правильного круга. Они образованы при вращении сосуда, закрепленного на жесткой оси (рис. 81, 1; рис. 82; рис. 83). На внешней стороне прослеживаются следы прорезного орнамента в виде частей треугольников.

Фрагмент миски. Краска нанесена на внешнюю и внутреннюю стороны в виде полос (рис. 81, 2; рис. 83, рис. 84).

Сосудов 2 класса найдено 126, в том числе три венчика ЭС-видной формы (рис. 85, 5, 6). Один фрагмент имеет бороздку под венчиком (рис. 85, 1). Один орнаментирован по внешней стороне прорезными линиями (рис. 85, 6; 86, 3). Найдена одна петельчатая ручка (рис. 86, 2; 87, 9). Есть фрагмент с заглаживанием внутренней поверхности (рис. 88). Особо следует отметить находку обломка двугорлого сосуда (рис. 86, 1; рис. 89).

Встречен обломок обгорелого лощила из кости черного цвета (рис. 90, 7).

Найдены сколы кремня 6 шт. (рис. 90, 1-6), три гальки (рис. 91, 1-3). Две из них имеют следы сработанности на торцовых частях (рис. 92). В заполнении ямы были также найдены два обломка конусов в виде их стенок с поверхностями основания (рис. 85, 4), желтый минерал с пачкающейся рыхлой структурой (рис. 91, б).

Створок раковин устриц найдено 70 шт., раковин гребешков - 6 шт. (рис. 93, 1) и боль- шое количество костей животных (рис. 93, 2). (Подробнее ниже).

Были получены две даты по костям животных из жилища 4 (табл. 4). Они очень близки и дают диапазоны 29-25 вв. до н.э.; 29-27 вв. до н. э.

\section{Раскоп 72015 г.}

Раскоп 7 (шурф 8) был заложен с целью поиска границ в восточном окончании возвышенности Тузла-15 (рис. 2). Его расстояние от квадрата 12015 г. около 80 м на восток. Точная привязка такова. Азимут 6 градусов от столба № 9 расстояние 84,6 м, азимут 327 градусов от столба № 10 расстояние 94 м. Точка привязки - угол А квадрата 6 N 45 10' 50,7' Е 036 38' 08,1'. Квадрат имеет площадь $2 \times 2$ м. Ориентирован по странам света. Углы получили обозначение АБВГ. Угол А-юго-западная точка квадрата. За Р0 принят угол А. Его отношение к реперному столбу № 7 равно +99 см. В квадрате на уровне материка обнаружены керамика майкопской культуры и признаки строения. Участок требует дальнейшего исследования.

\section{Раскоп 82015 г.}

Раскоп 8 (шурф 7) находится на восточном окончании всхолмления на расстоянии 125 м к востоку от квадрата 12014 г. Квадрат $2 \times 2$ м имеет широтную ориентацию. Углы обозначены литерами АБВГ. Угол А соответствует юго-западному окончанию квадрата. Более точная привязка угла А: азимут 55 градусов от столба 10. Расстояние от столба 10 до угла А 162 м. Высота угла А от репера столба $7+79$ см.

Р0 квадрата-является угол А. Точка привязки: угол А квадрата 7 N 45 10' 51,8', Е $036^{\circ} 38^{\prime} 10,9$ '. Поверхность квадрата распахана, нарушений нет (рис. 94).

Первый штык имеет глубину -5 см. Идет слой пахоты. Находок нет.

Второй штык имеет основание - 50 см. Идет слой пахоты. В северо-восточном секторе квадрата найдена каменная зернотерка. Размер зернотерки $20 \times 20$ см, толщина 


\section{Радиокарбонные даты жилища 4}

\begin{tabular}{|c|c|c|c|c|l|}
\hline № & \multicolumn{1}{|c|}{ Объект } & шифр & ВР & \multicolumn{1}{c|}{ ВС } & \multicolumn{1}{|c|}{ Примечание } \\
\hline 1 & 2014 г. Раскоп 5 & $\mathrm{Ki}-187808$ & $4070 \pm 60$ & $2860-2490$ & Из входа в жилище 4 \\
\hline 2 & 2015 г. Тузла-15, кость & $\mathrm{Ki}-19217$ & $4170 \pm 30$ & $2876-2676$ & $\begin{array}{l}\text { жилище № 4, кость } \\
\text { коровы, позвонки, } \\
\text { ребра }\end{array}$ \\
\hline
\end{tabular}

4 см. Вероятно, зернотерка была вывернута плугом при распашке виноградников. Слой распашки занимает 60 см в глубину и заканчивается на третьем штыке. Третий штык. Основание штыка 3 - 75 см. $100 \mathrm{~cm}$.

Четвертый штык. Основание штыка 4 -

Пятый штык. Основание штыка 5115 см. Уровень карбонатов начинается с глубины -90 см. Грунт меняется. С уровнем карбонатов связан слой материка - желтой глины.

Итоги шурфовки в раскопе таковы. Находок керамики практически не встречено. На третьем и четвертом штыках попадались
2-3 мелких фрагмента охристой майкопской керамики не более $0,5-1$ см в диаметре. Они могли разноситься землероями. В целом содержание шурфа вполне соответствует запустелой периферии поселения.

В северной стенке Б-В произведен отбор пробдля палинологического анализа (рис. 94).

Проба 1 глубина 115 от Р0 - верх карбонатного слоя палевый слой суглинка.

Проба 2 глубина -100 - -95 низ серого суглинка надкарбонатного слоя.

Проба 3 глубина -80 - -75 середина суглинка надкарбонатного слоя.

Проба 4 глубина -65 - -70 верх суглинка надкарбонатного слоя - граница распашки. 


\section{ГЛАВА 6.}

\section{Специальные определения по работам 2012-2015 гг.}

\section{Остеологические определения. Находки костей животных и раковин}

Кости животнъх и рыб. Таблица находок остеологических останков на объектах раскопок поселения Тузла-15. Анализы проведены к. б.н. Е.В. Добровольской

Pacкon 2. 2012 2. (квадрат. Всего учтен 61 определимый образец. Костей к.р.с- 33 (54\%), м.р.c. -13 (21\%), свинья $-5(8 \%)$, моллюсков - 10 (16\%).

Pacкоп 3. 2013 2. Помещение 2. Всего учтены 63 кости. Из них неопределимы37. Из определимой серии в 8 костей к.р.с. $(22 \%)$, костей м.р.с-10 (27\%), свиньи -5 (13\%), 1 створка устрицы, 2 кости рыб.

Pacкon 3. 2013 2. Помещение 3. Всего в коллекции учтена 401 кость животных, птиц и моллюсков. 207 костей трудноопределимы. Выборка определимых костей составляет 194 экз. Из них костей к.р.с. - 28 (14\%), м.р.с. -48 (24\%), свиньи - 11 (5,6\%). Одна кость собаки. 77 створок устриц-39,6\%. Присутствуют кости рыб-17 шт., одна кость гуся, две кости лебедя, две кости птиц неопределимы.

Pacкon 4. 2014 г. Постройка 4. Всего коллекция включает 318 костей животных. В ней 107 костей сохранились фрагментарно. Определимая серия включает 209 костей. В ней доминируют кости крупного рогатого скота (взрослые особи) - 34 (17\%) и мелкого рогатого скота (молодые особи) - 40 (19\%), присутствуют кости свиньи (взрослые и молодые особи) - 8 (3,8\%). Единично представлена собака, утка. Много раковин устриц - 118 (56\%). Остеологические данные представлены в целом серией из костей домашних животных: кости к.р.с. - 103, м.р.с. - 121, свинья - 21 .

В небольшом количестве присутствуют кости рыб, птиц: лебедь, гусь, утка.

В коллекциях комплексов 2, 3, 4 наборы костей похожи. Доминируют кости овцы, затем кости к.р.с., существенно меньше представлены кости свиньи. Единичны кости птицы и рыбы. Возможна постановка вопроса, что серии костей в жилищах отражают некие статистические наборы. Как они получились? Это следствия ритуальных пиршеств, связанных с обрядом консервации жилища? В целом набор костей типичен для поселений МНО. Специфику создает малое количество или даже отсутствие костей лошади.

В яме с теленком присутствовали кости к.р.с., м.р.с. и свиньи.

Раковины. При раскопках жилищ регулярно встречались створки раковин устриц и раковин гребешок. Раковины были найдены в комплексе 3 (около 60 створок) (рис. 55, 2), в помещении 4 (более 80 створок) (рис. 60). В обоих случаях раковины концентрировались по кучкам. В раскопе 5

\begin{tabular}{|l|c|c|c|c|c|c|c|c|}
\hline \multicolumn{1}{|c|}{ Объекты } & КРС & МРС & Собака & Лошадь & Птица & Рыба & Моллюски & Другие \\
\hline 2012 г. шурф 2 & 47 & 25 & 1 & - & 2 & 1 & 10 & \\
\hline 2013 г. яма 1 & & & 4 & 1 & & 4 & & $\begin{array}{c}34 \\
\text { обожжены }\end{array}$ \\
\hline 2013 г. комплекс 2 & 37 & 24 & & & & & 1 & 43 \\
\hline 2013 г. комплекс 3 & 28 & 48 & 1 & & & 4 & 77 & $\begin{array}{c}28 \\
\text { обожжены }\end{array}$ \\
\hline $\begin{array}{l}2013 \text { г. яма с } \\
\text { теленком (кости не } \\
\text { теленка) }\end{array}$ & 6 & 27 & & & & & & 119 \\
\hline 2014 г. комплекс 4 & 34 & 40 & 9 & & 2 & 1 & 118 & 107 \\
\hline
\end{tabular}


(квадрате 1) 2014 г. две раковины были зафиксированы в слое материка в стороне от границы жилища. (Возможно, они были туда утащены землероем?)

\section{Данные микробиоморфного анализа}

Для уточнения характера находок внутри выявленных ям комплексов и находок внутри ямы с теленком были проведены микробиоморфные исследования. Микро- биоморфный анализ органических образ цов поселении Тузла-15 был выполнен д. г. н. А. М. Гольевой по стандартной методике. Объектами анализа стали образцы грунта и золы из жилища 4 и образцы грунта из квадрата 72015 г. Результат анализа представлен в таблицах (табл. 5-8).

По результатам микробиоморфного анализа в образцах было определено количество валового фосфора. Результаты представлены в таблице 7.

Таблича 5

\section{Пробы для фитолитного анализа поселения Тузла-15}

\begin{tabular}{|c|l|l|l|}
\hline №№ & Год & \multicolumn{1}{|c|}{ Комплекс } & \multicolumn{1}{c|}{ Материал } \\
\hline 1 & 2015 & постройка 4 & грунт из кострища на дне ямы 2 \\
\hline 2 & 2015 & постройка 4 & зола из заполнения \\
\hline 3 & 2015 & постройка 4 & зола из заполнения \\
\hline 4 & 2015 & постройка 4 & грунт из ямы комплекса \\
\hline 5 & 2015 & постройка 4 & грунт из ямы комплекса \\
\hline 6 & 2015 & постройка 4 & грунт с поверхности с углем \\
\hline 7 & 2015 & квадрат 7 & гл. -65 - -70 \\
\hline 8 & 2015 & квадрат 7 & гл. - $75--80$ \\
\hline 9 & 2015 & квадрат 7 & гл. -95- -100 \\
\hline 10 & 2015 & квадрат 7 & гл. -115- -120 \\
\hline 11 & 2013 & яма с теленком & грунт с углем \\
\hline
\end{tabular}

Таблича 6

\section{Остатки органики}

\begin{tabular}{|c|c|c|c|c|c|c|}
\hline №№ & Образец & ДЕТРИТ & $\begin{array}{c}\text { Aморф. } \\
\text { Орг. }\end{array}$ & $\begin{array}{l}\text { Спик. } \\
\text { губок }\end{array}$ & $\begin{array}{c}\text { Диатом. } \\
\text { водорослей }\end{array}$ & Фитолиты \\
\hline 1 & $\begin{array}{l}\text { Из кострища, } \\
\text { комплекс 4, яма } 2\end{array}$ & +++ & +++ & ЕД & ЕД & + \\
\hline 2 & Зола, комплекс 4 & +++ & +++ & - & - & + \\
\hline 3 & Зола, комплекс 4 & +++ & ++ & - & + & ++ \\
\hline 4 & Грунт, комплекс 4 & + & +++ & - & - & ЕД \\
\hline 5 & Грунт с поверхности, 4 & +++ & +++ & - & - & - \\
\hline 6 & Грунт, комплекс 4 & ++ & +++ & - & - & - \\
\hline 7 & Яма с теленком & +++ & ++ & - & - & - \\
\hline 8 & квадрат $7-65--70$ & ++ & ++ & - & - & - \\
\hline 9 & квадрат $7-75--80$ & + & ++ & - & ЕД & ++ \\
\hline 10 & квадрат $7-95--100$ & + & + & - & - & - \\
\hline 11 & квадрат $7-115--120$ & + & + & - & - & - \\
\hline
\end{tabular}

Примечания. Микробиоморфы +++ - много (более 100 единиц в рассматриваемом объеме), ++ - среднее содержание (50-100 единиц), ЕД - единично (1-4 единицы), - - отсутствуют.

Специальные термины. Детрит-продукт распада г.о. органических тканей. Спикулы - известковые и кремневые скелетные элементы беспозвоночных, например губок. Фитолиты - остатки погибших растений, не подлежащие распаду. Диатомы (диатомные водоросли) - остатки погибших растений, имеющие кремневую основу, не подлежащие распаду. 


\section{Содержание валового фосфора}

\begin{tabular}{|c|c|c|}
\hline $\begin{array}{c}\text { Образец, в скобках - номер пробы } \\
\text { по описи }\end{array}$ & $\begin{array}{c}\mathbf{P}_{2} \mathbf{O}_{5} \%, \\
\text { вал }\end{array}$ & Комментарий \\
\hline \multicolumn{3}{|l|}{ Тузла-15, комплекс 4} \\
\hline $\begin{array}{l}\text { Грунт из кострища на дне ямы } 2 \\
\text { комплекса } 4\end{array}$ & 0,11 & Минеральный горизонт без органики \\
\hline Зола из заполнения комплекса 4 & 0,55 & \multirow[t]{2}{*}{ Культурный слой с растительным детритом } \\
\hline Зола из заполнения комплекса 4 & 0,76 & \\
\hline Грунт из жилища 4 & 0,64 & Культурный слой с растительным детритом \\
\hline $\begin{array}{l}\text { Квадрат 7, -65 - -70, надкарбонатный } \\
\text { слой }\end{array}$ & 0,13 & \multirow[t]{4}{*}{ Минеральный горизонт без органики } \\
\hline $\begin{array}{l}\text { Квадрат 7, -75 - -80, надкарбонатный } \\
\text { слой }\end{array}$ & 0,14 & \\
\hline $\begin{array}{l}\text { Квадрат 7, -95 - -100, карбонатный } \\
\text { уровень }\end{array}$ & 0,13 & \\
\hline Квадрат 7,-115--120, материк & 0,15 & \\
\hline $\begin{array}{l}\text { Грунт с поверхностью и углем (8) } \\
\text { Раскоп } 32013 \text { г. }\end{array}$ & 0,15 & Органоминеральный почвенный горизонт \\
\hline $\begin{array}{l}\text { Раскоп } 32013 \text { г. Яма с теленком, } \\
\text { грунт (8) }\end{array}$ & 0,27 & $\begin{array}{l}\text { Слаборазвитый культурный слой (объем } \\
\text { органической массы был небольшим) }\end{array}$ \\
\hline
\end{tabular}

\section{Заключение по микробиоморфным анализам органических образцов из комплексов поселения Тузла-15}

Раскоп 8 (Квадрат 7)-фоновый обвект. В раскопе 8 (квадрате 7, расположенном на окраине поселения, культурных отложений (керамики, орудий) не было зафиксировано.

Первый уровенъ. Отбор проб произведен с глубин под распаханным слоем от $-0,65--70$ см до $-112--120$ см. На глубине $-0,65--0,70$ см фитолитов вообще не выявлено. Почва отражает стерильный слой, говоря языком археологии.

Второй уровенъ. Ниже на глубине -75 -80 см начинается надкарбонатный слой, который соответствует уровню залегания культурных остатков на поселении. В нем хорошо представлены фитолиты, остатки растительности, отражающие спектр травостоя. В наибольшем количестве присутствуют фитолиты двудольных растений, луговых и степных злаков. Отмечены фитолиты тростника/камыша, осоки и мха, которые свидетельствуют о близости водоема. В единичном случае обнаружен культурный злак. Представлена и аридная флора. То есть растительность на периферии поселка была луговой, степной. Водный ресурс был неподалеку. Климат был жаркий, позволяющий произрастать аридным растениям.

Третий уровенъ. Ниже на карбонатном уровне почвенных отложений на глубинах $-95--100$ см, $-115--120$ см фитолитов нет, как нет и следов отложения в слое растительности. Видимо, почва с карбонатами отражает особо жаркий период, весьма неблагоприятный для произрастания травостоя.

Заключение. Перемена климата с большей увлажненностью прямо находит соответствие с появлением в данном месте носителей майкопской культуры.

Финал обитания поселка. Слои почвы, перекрывшие надкарбонатный уровень (первый уровень), вновь отражают отсутствие фитолитов и могут свидетельствовать, что финал обитания носителей псекупского варианта майкопско-новосвободненской общности совпал с новой трансформацией 


\section{Содержание валового фосфора}

\begin{tabular}{|c|c|c|c|c|c|c|c|c|c|c|c|c|c|}
\hline Образец & Всего & Спикулы & Диатомы & Фитолиты & 1 & 2 & 3 & 4 & 5 & 6 & 7 & 8 & 9 \\
\hline \multicolumn{14}{|l|}{ Комплекс 4} \\
\hline $\begin{array}{l}\text { Грунт из кострища } \\
\text { на дне ямы } 2\end{array}$ & $41 / 140$ & $1 / 2$ & $2 / 5$ & $38 / 93$ & 58 & - & 3 & 18 & 8 & 5 & 5 & - & 1 \\
\hline $\begin{array}{l}\text { Зола из заполне- } \\
\text { ния комплекс } 4\end{array}$ & $21 / 100$ & - & - & $21 / 100$ & 100 & - & - & - & - & - & - & - & - \\
\hline $\begin{array}{l}\text { Зола из заполне- } \\
\text { ния комплекс } 4\end{array}$ & $90 / 100$ & - & $4 / 4$ & $89 / 96$ & 47 & 2 & 3 & 22 & 17 & 7 & 1 & - & 1 \\
\hline Грунт из жилища & $2 / 100$ & - & - & $2 / 100$ & - & - & - & - & - & - & - & - & - \\
\hline \multicolumn{14}{|c|}{ Квадрат 7, разведка площади поселения } \\
\hline $\begin{array}{l}\text { Квадрат } 7-65--70, \\
\text { надкарбонатный } \\
\text { слой }\end{array}$ & - & - & - & - & - & - & - & - & - & - & - & - & - \\
\hline $\begin{array}{l}\text { Квадрат } 7-75--80, \\
\text { надкарбонатный } \\
\text { слой }\end{array}$ & $86 / 100$ & - & $4 / 4$ & $82 / 96$ & 44 & 1 & 2 & 24 & 19 & 8 & 1 & - & 1 \\
\hline $\begin{array}{l}\text { Квадрат } 7-95--100, \\
\text { надкарбонатный } \\
\text { слой }\end{array}$ & - & - & - & - & - & - & - & - & - & - & - & - & - \\
\hline $\begin{array}{l}\text { Квадрат } 7-115- \\
-120, \text { надкарбонат- } \\
\text { ный слой }\end{array}$ & - & - & - & - & - & - & - & - & - & - & - & - & - \\
\hline $\begin{array}{l}\text { Грунт } \\
\text { с поверхности }\end{array}$ & - & - & - & - & - & - & - & - & - & - & - & - & - \\
\hline $\begin{array}{l}\text { Грунт из ямы } \\
\text { комплекса }\end{array}$ & - & - & - & - & - & - & - & - & - & - & - & - & - \\
\hline \multicolumn{14}{|c|}{ Погребение с теленком } \\
\hline $\begin{array}{l}\text { Погребение } \\
\text { с теленком }\end{array}$ & $2 / 100$ & - & - & $2 / 100$ & 50 & - & - & 50 & - & - & - & - & - \\
\hline
\end{tabular}

Растительные иенозы: 1 - двудольные травы; 2 - хвойные; 3 -лесные травы; 4 -луговые злаки; 5 - степные злаки; 6 - аридная флора; 7 - культурные злаки;8 - тростник, камыи, осока; 9-мхи. Пояснение к определениям. Культурные злаки - это, например, полба (пшенича), ячмень, овес.

климата и исчезновением злаковой степной растительности. Фосфор содержится в грунте квадрата 7 в нормальных фоновых концентрациях 0,13-0,15\%, не предполагающих насыщения грунта остатками органики.

Помещение 4. Сразу обращает на себя внимание, что зола из комплекса 4 насыщена детритами и аморфными частицами органики. Среди фитолитов доминируют двудольные травы, много луговых злаков, степных злаков. Есть злаки аридной флоры и культурные злаки, фитолиты тростника/камыша. Единичны мхи. Спектр фитолитов практически идентичен спектру травостоя из предкарбонатного слоя ква- драта 72015 г. Иными словами, здесь мы имеем отражения естественного фона растительности в округе поселка.

Резкое различие наблюдается по содержанию фосфора в золе из помещения 4 и из квадрата 7. Содержание фосфора в золе из комплекса 4 находится в рамках $0,5-0,76 \%$. В квадрате 7 на глубинах - 0,65-120 см содержание фосфора равно всего лишь $0,13-0,15 \%$. Это содержание фосфора можно принять за естественный фон в почве. То же самое низкое содержание фосфора отмечается в грунте на дне ямы 2 помещения $4(0,11 \%)$, который был отобран без включений золы. 
По общим представлениям ботаники, содержание фосфора в грунте колеблется от 0,01 до 0,3\%. То есть если бы для получения данного состава золы была просто сожжена трава с поверхности поселения, мы бы не получили такого повышения фосфора в золе из жилища. Значит, в огонь для получения рассматриваемого объема золы было добавлено нечто, что повлекло за собой повышение фосфора в продукте горения.

Анализ материала показал, что для получения золы из комплекса 4 были сожжены значительные объемы древесины, соломы злаковых или бобовых, трав (растений) и животной органики: шкуры, кожи, костей и прочих животных материалов. Наличие очажного места в яме комплекса 4, небольшого прокала почвы не позволяет полагать связь продуктов горения с разведенным огнем на дне ямы. Повышение фосфора косвенно может свидетельствовать о том, что продукты горения были получены вне ямы 2. Они были связны с местом обита- ния человека, которое располагалось где-то рядом. Как конечный продукт горения, полученную золу сразу принесли и бросили в яму 2. (Полагаю, что долго держать большую кучу золы на поверхности невозможно, она будет рассеяна ветром или дождем).

Яма с теленком. Грунт из придонной части ямы с теленком насыщен детритами. Они присутствуют в заполнении погребения в большем количестве, чем в грунте квадрата 72015 г., в котором культурных отложений не было зафиксировано. В грунте ямы с теленком есть фитолиты двудольных трав и луговых злаков. Такое содержание фитолитов отличается от его содержания в материковом грунте квадрата 7 или в образце с современной поверхности, в которых фитолиты вообще отсутствуют. Содержание фосфора $0,21 \%$ в яме с теленком несколько превышает его уровень в местной почве, но не намного. Заполнение ямы можно определить как грунт, отражающий слабо развитый культурный слой. 


\section{ГЛАВА 7. Артефакты поселения}

\section{Керамика из раскопок поселения Тузла-15}

Коллекция керамики из раскопок на поселении Тузла-15 2012-2015 гг. происходит из раскопок слоя поселения вне ям и из ям-построек. Для общего представления о находках следует заметить, что находки керамики представлены исключительно черепками разного размера. Целых сосудов нет. Формы посуды, как правило, не реконструируются. Судить о них можно лишь в самых общих чертах.

Часто встречаются мелкие черепки размером в ладонь (в среднем $8 \times 8$ см) или менее. Они образуют так называемое керамическое крошево, то есть продукты дробления уже разбитых частей сосудов.

Полученную коллекцию керамики возможно представить в виде общего описания и конкретных наборов по комплексам построек.

Обиее описание керамики.

В 2004 г. была опубликована типология керамики МНО и принципы ее классификации. Особенностью подхода к формальному анализу рассматриваемых источников стало совмещение форм керамических изделий и состава формовочных масс. Для исследования последних были использованы методические приемы, заложенные в принципы изучения посуды при помощи микроскопа с 12-кратным увеличением. Разработка такой методики связана с именем выдающегося исследователя керамики А. А. Бобринского (Бобринский, 1978).

В работе с керамикой МНО мы старались использовать целые формы сосудов, в изобилии представленных в захоронениях МНО, и крупные детали разбитых в древности горшков, чьи контуры оставались еще не ясными (Кореневский, 1995. С. 21-29).

Специальное внимание было уделено форме венчиков и доньев, наличию ручек, орнаментов и знаков на посуде.
Был сформулирован тезис о том, что гончары МНО использовали поворотные устройства, выполняющие ранние формы гончарного круга (Кореневский, 1995; 2004. С. 22-35; Кореневский, Кизилов, 2015. С. 195-210; Кореневский, 2016а. С. 199-226).

По особенностям формовочных масс керамика МНО была подразделена на посуду 1 класса без искусственных минеральных примесей, изготовляемую с помощью поворотных устройств; посуду с искусственными минеральными примесями, изготовляемую без строгого контроля над симметрией формы и без использования поворотных устройств, посуду 3 класса, внешне напоминающую посуду класса 1 , но изготовляемую из формовочных масс с искусственными минеральными примесями.

Помимо минеральных примесей в состав формовочных масс нередко входили органические примеси.

Керамика закрытых форм 1 класса, как отмечалось выше, обладала высокой симметрией формы. Верхняя часть сосуда могла иметь остро рельефный переход от туловища к венчику, который воспринимался как ребро на внутренней поверхности ниже венчика. Подобная деталь конструкции могла отражать в отдельных случаях приставное горло сосуда.

Внешние поверхности сосудов, изготовленных из формовочных масс без минеральных примесей, тщательно обрабатывались, лощились, иногда покрывались ангобом.

Формы тулова сосудов 1 класса с закрытым контуром представлены тремя разновидностями: шаровидной с округлым и уплощенно-округлым дном, шаровидноуплощенной с туловом с округлым дном, с шаровидно-грушевидным контуром тулова с плоским дном.

Эти три разновидности посуды легли в основу выделения трех типологических вариантов МНО: галюгаевско-серегинского 
варианта (или собственно майкопского варианта), псекупского и долинского. Для галюгаевско-серегинского варианта характерна керамика шаровидных форм с округлым и уплощенно-округлым дном; для псекупского варианта показательна керамика 1 класса с шаровидно-уплощенным туловом; для долинского варианта типична керамика 1 класса с шаровидно-грушевидным туловом и плоским дном.

Новосвободненская группа своими типами посуды с тестом без минеральных примесей не выделяется.

Размеры и емкости сосудов закрытых форм 1 класса различны: от сосудов на 300500 мл до огромных пифосов на несколько десятков литров.

Вместе с сосудами закрытых форм из формовочных масс без минеральных примесей изготовлялись разнообразные миски и крупные открытые сосуды - чаны. Толщина стенок и чанов достигала 1 см и даже 2 см.

Крупные сосуды 1 класса (пифосы и чаны) изготовлялись из теста без минеральных примесей с примесью органики и жвачного корма животных. Последние примеси оставляли щели в формовочной массе.

Керамика 2 класса с искусственными минеральными примесями изготовлялась «от руки», без четко фиксированных следов использования поворотных устройств. Фактически к керамике 2 класса можно отнести все виды формовочных масс, которые не попадают под критерии формовочных масс 1 класса.

Поверхности сосудов, найденные на поселениях МНО, 2 класса несут свидетельства пребывания во вторичном пламени. Они заглаживались. Цвета их различны: охристые, бурые, черные. Особо показательны отделкой сосуды 2 класса новосвободненской группы «горизонта кладов». Их внешняя поверхность могла лощиться до черного блеска или иметь ярко-красный, охристый цвет.

Формы сосудов 2 класса МНО известны гораздо хуже, чем формы посуды 1 класса, так как в захоронениях такая керамика встречается не часто. Среди них есть круглодонные и плоскодонные сосуды закрытых форм. Миски довольно просты по оформлению венчиков, которые у закрытых сосудов нередко имеют ЭС-видную конфигурацию. Для керамики Галюгаевского 1 поселения на Тереке в качестве искусственных минеральных примесей отмечена дресва, реже шамот и смесь дресвы и шамота. Совершенно не была установлена примесь ракушки (Кореневский, 2004. С. 23).

Ниже перейдем к характеристике керамики поселения Тузла-15. По типу формовочных масс керамика поселения Тузла-15 распадается на два класса, которые характерны для посуды МНО в целом.

Обломки сосудов 1 класса представлены в виде венчиков открытых мисок разного диаметра (рис. 95-1, рис. 95-2, 1-4).

В большинстве случаев для мисок характерен г-образный или т-образный венчик (Кореневский, 2004. С. 168, рис. 42). Миски имеют красный и черный цвета (рис. 95-2, 1-4). Есть один экземпляр серого (черно-серого) цвета внешней поверхности и серого цвета на внутренней поверхности. Излом черепка отражает однородную формовочную массу хорошо отмученного состава (рис. 95-2, 5). Дно мисок скорей всего было округлым по примеру миски, найденной в 2011 г. (рис. 3).

Обломки мисок незначительны по своим размерам. Часто их диаметры восстанавливать трудно. Вместе с тем фиксируются миски с диаметром более 32-34 см (рис. 3). Имеется фрагмент крупной миски с толщиной стенки до 15 мм и диметром до 38 см (рис. 96-2, 1).

Встречены обломки венчиков закрытых сосудов с остро рельефным переходом от тулова к венчику (рис. 9,2 ; рис. $15,1,3$; 96-2, 1, 3, 4) и без такого перехода (рис. 47, 1, рис. 96-2, 5), а так же с наклоном венчика внутрь (рис. 96-2, б).

Иногда отмечается желоб под венчиком с внешней части сосуда (рис. 7,2 ; рис. 47,1 ; рис. 96-1, 4).

В постройке 3 найдены обломки керамики с ручками, поставленными на плечо шаровидно-уплощенного тулова сосуда (рис. 47,1$)$. Один раз в постройке 3 встречено плоское дно (рис. 51, 1). 
В наборах керамического боя сосудов 1 класса не зафиксированы детали крупных майкопских пифосов и мелких кубков. Видимо, такова особенность полученной выборки.

Для керамики 1 класса поселения Тузла-15 известны примеры окрашивания. В одних случаях они проявляются как пятна красноватого охристого цвета (рис. 46, 1). В других случаях как полосы густого красного цвета по охристой желтоватой основе или полосы коричневатого цвета по красноватой поверхности сосуда. Окрашенные полосы встречены на внешней и внутренней поверхностях миски из постройки 3 (рис. 53). Цветные полосы встречены также на крупном обломке миски из постройки 4 (рис. 82; 83).

Керамика 1 класса несет следы вращения и использования круговых устройств. Они отражены в симметрии форм венчиков и строго параллельными дугами окружностей (рис. 96-1, 1), а также окрашенными дугами полосок на миске из постройки 4 (рис. 83). Следы вращения прослеживаются на мисках из Натухаевского поселения (рис. 97, 1-4).

Очень редкими находками являются фрагменты керамики 1 класса с черной поверхностью (рис. 77, 5).

Керамика 2 класса с искусственными минеральными примесями в составе формовочных масс в коллекции поселения Тузла- 15 выделяется по насыщенности сосуда примесями ракушки. Включений ракушки очень много. Они видимы на глаз как белесые вкрапления. И, конечно, такие включения легко различимы при увеличении под микроскопом. В других случаях с керамикой 2 класса связаны формовочные массы, имеющие в изломе черепка черный цвет, рыхлую, пористую структуру и иные признаки, не причастные к керамике 1 класса.

Обломки керамики 2 класса представлены крупными фрагментами венчиков. В постройке 1 (рис. 14, 1) диаметр фрагмента венчика достигает 32 см. Такой же крупный венчик найден в жилище 4 (рис. 61,1 ) Его диаметр около $36 \mathrm{~cm}$.

В раскопе 2 (шурфе 2) 2012 г. есть находка дна сосуда второго класса диаметром
12 см, связанного с находкой постройки 1 2012 г. (рис. 14, 7). По микропримесям ракушки это дно совпадает с фрагментом венчика и обломками стенок (рис. 14, 1; рис. 22). Обломок плоского дна сосуда 2 класса размером $10 \times 10$ см и толщиной до 2 см найден в постройке 3 (рис. 47, 2).

Крупных обломков стенок сосудов второго класса с минеральными примесями ракушки не наблюдается. Их мелкие фрагменты встречены в раскопе 22012 г. (рис. 22). Бой керамики 2 класса с примесями ракушки зафиксирован в постройке 3 (рис. 36; рис. 45, 16; рис. $48,13-35$; рис. 50, 6-15; рис. $51,3,12-14)$. Он также имеется в постройке 4 (рис. 70; рис. 87).

Из индивидуальных находок керамики 2 класса можно отметить несколько случаев. В постройке 1 найден фрагмент керамики 2 класса с двухцветными поверхностями: черной внешней и охристой внутренней (рис. 9, 1), как следствие специфического обжига. Здесь же найден фрагмент плоского дна черного цвета с намечающимся поддоном (рис. 9, 4).

В постройке 4 найден фрагмент венчика сосуда 2 класса с внешней поверхностью розового цвета, на которой сохранились детали орнамента, проведенного прочерченными линиями (рис. 86, 3). Там же найден фрагмент керамики 2 класса серого цвета с черной полосой (рис. 64, 12) и обломок стенки сосуда 2 класса с заглаженной внешней поверхностью и с внутренней поверхностью, имеющей след заглаживания (рис. 88).

В раскопе 22012 г. зафиксирован фрагмент ленточной ручки с налепным орнаментом шишечками по краям. Ручка связана с сосудом, имеющим примеси ракушки в формовочной массе (рис. 10, 3). Еще один фрагмент со следом постановки ручки на сосуд происходит из постройки 12012 г. (рис. 14, 4). В раскопе 22012 г. найден фрагмент дна сосуда с отпечатками циновки (рис. 10, 1). Там же зафиксирован небольшой фрагмент миски 1 класса с Г-образным венчиком (рис. 10, 9) и фрагмент сосуда 2 класса с миндалевидными налепами (рис. 14, 10). 
В постройке 42015 г. найден фрагмент ручки-петельки для сосуда 2 класса (рис. 86,2$)$.

К керамике 2 класса относится обломок двугорлого сосуда из жилища 4 (рис. 86, 1). Формовочная масса сосуда имеет черный цвет. В ней много пор, видимо, вследствие выгорания органики. Есть мелкие обломки ракушки как естественной примеси в глине. Но высокого насыщения примесями ракушки, как в такой керамике Тузлы- 15 , нет. Внешняя поверхность сосуда имеет охристо-серый цвет, заглажена. На внутренней стороне сосуда имеются следы прикрепления выступающих венчиков (горловин) к отверстиям, которые были сделаны в полом теле сосуда.

Общее заключение по керамической коллекции поселения Тузла-15 2012-2015 гг. таково. Керамика поселения Тузла-15 представлена двумя технологическими классами 1 и 2, что является типичным явлением для поселений МНО. Керамика в изобилии встречается в комплексах ям, связанных с постройками, а также в скоплениях в культурном слое.

В раскопе 22012 г. зафиксирована ситуация с нижним и верхним уровнями залегания керамики (рис. 13). На верхнем уровне залегания черепков фиксировались лишь черные обломки керамики, насыщенные примесями ракушки. Мощность культурного слоя фиксируется до 30 см и более (рис. 12, 2).

Керамика из построек 1, 3 и 4 представлена обломками мисок 1 класса, среди которых есть крупные изделия с диаметром от 32 до 38 см. Такая посуда могла использоваться для приема растительной (зерновой) пищи, различных каш. Сосуд с ручками мог служить для вмещения жидкостей на несколько литров.
Керамика с минеральными примесями 2 класса сохранила свидетельства о крупных сосудах с плоским дном, имеющим диаметр 10 см и широкими венчиками более 30 см. Это явно была тарная керамика, пригодная для хранения сыпучих грузов и различных запасов.

\section{Обломки глиняных конусов, зернотерок и орудий}

Обломок глиняной подставки к очагу (или глиняного конуса) был встречен в жилище 12012 г. в виде фрагмента головки описываемого предмета (рис. 10, 13). Там же найден обломок стенки полой части конуса (рис. 15, 7). Обломок полой головки конуса найден в постройке 3 (рис. 54, 1). В квадрате 12014 г., то есть в жилище 4, отмечен обломок нижней части полой стенки конуса (рис. 61, 3). Детали подставок относятся к формам конусов с полым телом, которые характерны для псекупского варианта майкопско-новосвободненской общности (Кореневский, 2013).

Фрагменты зернотерок зафиксированы в слое раскопа 2 (рис. 13, 2). В яме 2 постройки 2 (рис. 25-2), в яме с теленком (рис. 37). Скопление камней, и в том числе зернотерок, отмечено при начале раскопок постройки 3 (рис. 39, 4) и в жилище 3 (рис. 44, 9-11). Зернотерки представляют собой плоские изделия из камня ракушечника.

Небольшое каменное тесло на гальке найдено в квадрате 12014 г. в жилище 4 (рис. 64,10$)$. Обожженное лощило из кости найдено в жилище 4 (рис. 90, 7).

В жилище 4 зафиксированы два небольших отбойника на гальке (рис. 92). Небольшие гальки найдены в жилище 3 (рис. 52, 4).

Нечастыми находками являются отщепы кремня из жилища 4 (рис. 61 , 5; рис. 90, 1-6). 


\section{ГЛАВА 8.}

\section{Хронология памятника}

Хронология раскопанных комплексов поселения Тузла-15 относится к финалу МНО (табл. 9). Она может даже захватывать первые века III тыс. до н. э. Наиболее близкие поселению Тузла-15 памятники Чекон I и Чекон отражают даты среднего и позднего диапазонов дат ${ }^{14} \mathrm{C}$ для майкопско-новосвободненской общности.

Так, поселение Чекон имеет несколько радиоуглеродных дат (Гей, Зазовская, 2013. C. 81-84). Общий диапазон их с вероятностью 68\% таков: ИГАН $42434510 \pm 60$ ВР 3311-2918 ВС. (Раскоп 1 кв. 23 яма 55, лошадь крупная, первый уровень расчистки). ИГАН $42564810 \pm 90$ ВР 3660-3519 ВС. (Рас- коп 1, полуземлянка № 54 яма 2 2-й уровень расчистки (кости к.р.с.)). Авторы публикации предлагают диапазон дат поселения, как интервал 37-32 вв. до н. э. На самом деле он немного шире: 37-30 вв. до н. э.

Даты погребений 2011 г. на поселении Чекон таковы. Погребение 1, кость, навес 18 гр. Кi-18074 $4410 \pm 90$ BP 3398-2911 ВC, то есть примерно 34-30 вв. до н. э. Погребение 2 Чекон 2011 г. Кость. Навес 38 гр. Кі$180754690 \pm 110$ ВР 3637-3357 ВС. В итоге получается диапазон 37-34 вв. до н. э.

Сопоставляя данные поселений Чекон 1 и Чекон, можно прийти к заключению, что это были два очень близких

Таблича 9

\section{Даты поселения Тузла-15}

\begin{tabular}{|c|c|c|c|c|}
\hline Объект & Шифр & BP & BC & Примечания \\
\hline 2012 г. Раскоп 2, кость животного 2 & Ki-17989 & $4230 \pm 30$ & $2920-2700$ & $\begin{array}{l}07.02 .2013 \\
82 \text { гр. Шт. } 3\end{array}$ \\
\hline 2012 г. Раскоп 2, кость животного 3 & Ki-17990 & $4170 \pm 30$ & $2880-2580$ & 85 гр. Шт. 4 \\
\hline 2012 г. Раскоп 2, кость животного 3 & Ki-17991 & $4180 \pm 60$ & $2880-2660$ & $\begin{array}{l}85 \text { гр. Шт. } 4 \text { яма. } \\
\text { Комплекс } 1\end{array}$ \\
\hline 2012 г. Раскоп 2 штык 4 & Ki-17861 & $4310 \pm 110$ & $3081-2876$ & Культурный слой \\
\hline 2013 г. Раскоп 4. & Ki-18584 & $4510 \pm 60$ & $3355-3035$ & Комплекс 3 \\
\hline 2013 г. Раскоп 4. & Ki-18168 & $4570 \pm 80$ & $3331-3123$ & Комплекс 3 \\
\hline 2013 г. Раскоп 4. & Ki-18589 & $4440 \pm 80$ & $3340-2919$ & Комплекс 3 \\
\hline 2013 г. Раскоп 4 кость 9 гр & Ki-18172 & $4610 \pm 150$ & $3620-3047$ & $\begin{array}{l}\text { зачистка } \\
\text { по материку }\end{array}$ \\
\hline 2013 г. Раскоп 4 & Ki-18585 & $4090 \pm 60$ & $2858-2499$ & яма с теленком \\
\hline 2014 г. Раскоп 5 & Ki-187808 & $4070 \pm 60$ & $2860-2490$ & $\begin{array}{l}\text { Из входа } \\
\text { в постройку } 4\end{array}$ \\
\hline 2015 г. Тузла-15, кость & Ki-19217 & $4170 \pm 30$ & $2876-2676$ & $\begin{array}{l}\text { постройка № } 4, \\
\text { кость коровы, } \\
\text { позвонки, ребра }\end{array}$ \\
\hline Чекон 1 р. 1, шт. 2 керамика 72 гр. & Ki-17919 & $4490 \pm 150$ & $3490-2917$ & \\
\hline Чекон 1 кв. 6 , яма 2 , кость 84 гр. & Ki-17918 & $4120 \pm 70$ & $2873-2504$ & \\
\hline Чекон, 2011 г. & & $4410 \pm 90$ & 3398-2911 & \\
\hline
\end{tabular}


памятника, если даже не один памятник. Оба поселения отражают характерные черты местного псекупского варианта МНО, которые должны получить всестороннюю интерпретацию в будущем с учетом раскопок 6000 м $^{2}$ на поселении Чекон А. И. Юдиным в 2018 г.

Близкими по времени финалу функционирования поселений Тузла- 15 и Чекон могут быть уже известные памятники с поздним диапазоном дат ${ }^{14} \mathrm{C}$ МНО (Кореневский, 2011. C. 29, 30), а также Нальчикская гробница 3092-2943 ВС 68\% (Belinskij et al., 2017). и погребения 15 могильника Ольховский Ki - $192254400 \pm 50$ BP 3096-2901 BC (Kopeневский и др., 2018)

Регулярно встречаемые даты комплексов Тузла-15 (постройка 4) очень позднего возраста для ее памятников позволяют считать, что носители майкопско-новосвободненкой общности в условиях Причерноморской зоны ее ареала могли продолжать жить в начале III тыс. до н.э. и сосуществовать с наступающей новой эпохой среднего бронзового века Предкавказья на других территориях. 


\section{ГЛАВА 9.}

\section{Комплексы ям поселения Тузла-15 и типология построек майкопско-новосвободненской общности}

\section{Комплексы построек поселения Тузла-15 и бытовые сооружения МНО}

Открытые нами комплексы ям на поселении Тузла-15, заполненные обломками керамики и отходами пищи, возможно, представлены как ямы со специфическими деталями устройства в виде ступенек или ям двучастной конфигурации. Такие формы не соотносятся с понятиями обыденной ямы, вырытой для складирования отходов быта. По своим размерам они также отличаются от обычных ям для бытовых отходов. Формы мусорных ям круглые, а размеры, как правило, не превышают 1-1,3 м. Размеры двучастных ям и ям со ступеньками больше 1,5 м и доходят до 3 с лишним метров. Поэтому мы называем их постройками, которые могли быть частями полуземлянок или самими полуземлянками. Далее рассмотрим сведения о жилищах МНО в свете сделанных открытий на поселении Тузла-15. В изложенном ниже списке памятников мы отмечаем в основном поселения, на которых были выявлены ямы, содержащие находки, или ямы со ступеньками.

В настоящее время мы располагаем сведениями примерно о 40 бытовых постройках или ямах-комплексах майкопско-новосвободненской общности, не учитывая находок небольших хозяйственных ям. Их перечень представлен ниже в зависимости от зоны в пределах ареала МНО.

\section{Причерноморская зона}

Поселение Тузла-15. Найдено 4 комплекса, описанных выше, которые возможно интерпретировать как постройки с ямами или жилища.

Постройка 1 определена как яма со ступенъкой. Яма немного сужается ко дну и несколько меняет контуры. Ее размер по линии запад-восток составляет 222 см, по линии север-юг 200 см. Дно ямы находится на глубине -116 см. В юго-восточной части ямы выявлена ступень. Длина ступени по линии Ю3-СВ - 140 см, ширина ступени по линии ЮВ-С3 - 36 см. Глубина ступени - -96 см (то есть она ниже поверхности зачистки на 22 см). Дно ямы, таким образом, имеет длину по линии ЮЗ-СВ - 190 см, ширину по линии ЮВ-С3 - 150 см (рис. 16; 17). Следов очага нет. В яме найдены фрагменты керамики и обломок глиняного конуса-приставки к очагу.

Постройка 2 зафиксирована как подпрямоугольное строение, ориентированное по сторонам света (рис. 24). Его размеры $3,4 \times 3,2$ м. Дно открытого помещения неровное. В квадрате 5 оно имеет углубление до глубины -120, -119 см (так называемая яма 2). В квадрате 5 в пределах ямы 22013 г. встречен обломок зернотерки на глубине -82 см (рис. 25-2) и северо-восточнее от него развал черепков (миски черного цвета).

Постройка 3 выявлена в виде конструкции, заполненной находками, которая может быть интерпретирована как жилище 3. От него сохранилась яма 2 с входом-ступенькой (ямой 1) (рис. 41; рис. 42). Размеры полуземлянки, судя по ее границам, составляли в длину по линии СЗ-ЮВ - 274 см, по линии ЮЗ-СВ-172 см. Причины, почему зона входа обозначилась на глубине - 75 см как отдельное пятно, могут быть неоднозначны. Не будем забывать, раскопки проходили в зоне культурного слоя, а здесь, как и в насыпи кургана, пятна могут «не читаться» или проступать неравномерно. Следов очага не найдено. При расчистке заполнения строения найдены различные камни, многочисленные фрагменты лепной керамики с искусственными минеральными примесями и керамики высокого класса без минеральных примесей, обломок глиняного 
конуса-приставки к очагу, кости животных, рыб, раковины. Некоторые кости животных обожжены. Следов очага не найдено.

Постройка 4. Обнаруженная конструкция представляет собой яму двучастной формы. Ее западная часть имеет прямую стенку. Восточная часть ямы придерживается контуров овала. Яма ориентирована по длинным осям с юго-востока на северо-запад и с юго-запада - на северо-восток. Размеры ее по этим осям соответственно 185-180 см. Уровень фиксации верхних стенок ямы связан с глубинами около -80 см. Но более определенно ее контур читается на глубинах -110 м, то есть в материковом слое. Яма имеет внутреннюю каменную стенку-разделитель и очаг (рис. 72-1; рис. 72-2).

Поселение Чекон 1 (раскопки Бонина А.B. 2010 г.) (Бонин, 2013 г.; Бонин и др., 2013). Объектами раскопок поселения являются ямы. Диаметр ям не превышает 1,6 м. Глубина ям составляет $-0,25--0,35$ м. Материалы из ям идентичны находкам в культурном слое. Керамическая коллекция включает миски с округлым дном с разной конфигурацией венчика. Обломки сосудов 1 класса составляют около $60 \%$ коллекции. Есть фрагмент горла кубка с граффити (знаком) по сырой глине (Бонин и др., 2013. С. 18, рис. 13, 4). Встречено несколько обломков глиняных конусов с намечающимся расширением шляпкой и прогибом основания тулова.

Поселение Чекон (или Чекон 2) (раскопки В.В. Бочкового 2011 г.) (Бочковой и дp, 2012; Бочковой, 2013; Бочковой и др., 2013)). Поселение Чекон располагается рядом с поселением Чекон 1. Раскопки 2011 г. на нем велись траншеей шириной в 5 м вдоль железнодорожного полотна, согласно техническому заданию строительства. Е.Н. Булах (Булах, 2014) описал три жилища-полуземлянки, открытые на поселения Чекон 2. № 17, 29, 34. Следов очагов на них отмечено не было. Объекты начали раскапываться с уровня материка и слоя выхода карбонатов, глубина расчистки составляет несколько более 20 см. Наиболее полно представлено жилище в кв. 5, описанное как объект № 17. Контуры сооружения отражают явно яму двучастной формы. Одна часть напоминает овал. Это само пространство жилища размером 3,29×2,93 м. Дно несколько прогнуто. Вторая часть имеет подпрямоугольные контуры размером $1,73 \times 1,75$ м. Она может восприниматься как вход. В целом конструкция была вытянута с ЮЗ на СВ.

Скопления находок были отмечены в виде двух куч в основной овальной части и в площади входа. В их состав входили камни-известняк, бой сосудов (не восстанавливается целиком ни один). Находки были представлены керамикой, костями животных (коровы, овцы) и костями рыб. При этом кости коровы были разбиты и представляли остатки трапез. Среди иных находок встречены фрагмент глиняной обмазки, керамический шлак, галька, отщеп кремневый, костяной молоток.

Е.Н. Булах в заключение своей публикации пишет, что отождествление полуземлянок с жилищами не совсем правомерно. Это могли быть хозяйственные постройки различного назначения, в том числе для хранения различного сырья, используемого в производстве, керамики, орудий из кремня, обработки дерева и иных хозяйственных нужд (Булах, 2014. С. 30-33).

Поселение Натухаевское-3. (Раскопки А. В. Шишлова, А.В. Колпаковой, И. В. Федоренко, 2007, 2008 гг. и в другие годы). Поселение Натухаевское-3 было открыто в 2007 г. в 18 км к северо-западу от г. Новороссийска. Оно расположено на пологом склоне г. Мысхако на левом берегу р. Котлама на южной окраине ст. Натухаевской. В 2007 г. на поселении было заложено 15 шурфов общей площадью 95 м². Было открыто шесть хозяйственных ям майкопско-новосвободненской общности. В 2008 г. исследование поселения было продолжено. Культурный слой на склоне холма был смыт. Поэтому фиксировались только объекты, впущенные в материк. Общая площадь работ 2008 г соста-

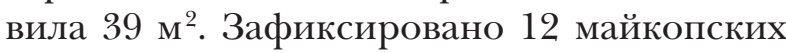
хозяйственных ям, вытянутых цепочкой поперек склона на протяжении 28 м². Таким образом, на поселении было выявлено 18 ям периода МНО. Все они имели округлую форму размеры 140×142 см и 250-212 см, глуби- 
на от уровня материка достигала -124 см. Ямы № 1 и 7 имели площадки, напоминающие ступеньки. Заполнение ям составлял серо-коричневый суглинок (Шишов и др.,2007; Шишлов, Федоренко, 2008; Шиилов и др., 2009; Шишлов и др., 2010; Шишлов и др., 2013; Шишлов, 2012; Шиилов и др., 2013).

Поселение Катусвина Кривица-2 расположено на северо-западной окраине ст. Натухаевской под г. Новороссийском. Оно раскапывалось коллективом новороссийских археологов, содержит материалы псекупского варианта МНО и близко по керамике поселению Натухаевское-3. Мощность культурного слоя поселения составляет около 50 см. На поселении открыто множество круглых ям. В одной из них найдено захоронение человека. Скелет мужчины 30-35 лет лежал в круглой яме в позе скорчено на спине. Левая рука была согнута в локте, кистью у черепа (Шишлов и др., 2014; Шишлов и др., 2015. С. 120 , С. 121 рис. 4, 1).

Поселение Старотитаровское. В июне-августе 2015 г. «Старотитаровский» отряд ООО «Археологическое общество Кубани» под руководством Ш.О. Давудова (Кореневский, Давудов, 2019) проводил раскопки крупного поселения античного времени у Старотитаровской (рис. 98) в 40 км на восток от ст. Таманской Краснодарского края. Поселение расположено в 6,1-6,75 км к западу-северозападу от кладбища ст. Старотиторовской. Вместе с античной керамикой были найдены сосуды и иные артефакты эпохи раннего бронзового века. Сам слой этого периода практически не прослеживается.

В число находок эпохи медно-бронзового века входит ударное оружие, напоминающее топор с отверстием, длиной 11 см. Диаметр отверстия для насада рукояти 2 см. Орудие сломано, у него отбита обушная часть (рис. 99, 1). Следующим орудием является кремневая пластина с ретушью по краям длиной 6 см (рис. 99, 2). Далее следует упомянуть сосуды ручной лепки с восстановленным туловом. Два сосуда крупные высотой 26 и 28 см с прямым венчиком, слегка отогнутым наружу, высота венчиков 4 и 5 см. Один сосуд имеет округлое дно (рис. 99, 3) другой (рис. 99, 4), видимо, тоже. Три небольших сосуда (рис. 99, 7, 8, 9,) имеют в высоту около 10 см. Один напоминает кубок (рис. 99, 8). Другой - плоскодонный горшок с хорошо обозначенным туловом и отогнутым наружу венчиком (рис. 99, 9). Третий сосуд с высотой около 8 см имеет круглое дно и прямой венчик (рис. 99, 7).

Двугорлый сосуд ближневосточного типа, такой же, как на Тузла-15, найден в обломках (рис. 99, 10). Полностью восстановлен охристый сосуд из теста без минеральных примесей красно-охристого цвета. Высота его тулова около 17 см, высота венчика около 4 см. Тулово сосуда имеет ребро. На верхней части реберчатого тулова сосуда нанесен наклонными прорезными линиями орнамент (рис. 99, 11). По этому признаку он совпадает с реберчатыми майкопскими сосудами группы РБ-2 (Кореневский, 2004. Рис. 43, 45). Аналогии им известны из разных памятников Западного Предкавказья, например, из кургана Синюха (Трифонов, 2014. С. 278, рис. 2, 1; Шишли на и др., 2015; Эрлих и др., 2013). Один такой сосуд из погребения 15 кургана могильника Ольховский имеет дату Кi-19225 $4400 \pm 50$ ВР 3096-2901 ВС, о чем уже упоминалось выше (Кореневский и др., 2019).

Совершенно неожиданным явлением в раскопках поселенческого характера поселения стала находка в яме, по размерам близкой к полуземлянке, коллективного захоронения (объект 58-Б) четырех человеческих костяков (рис. 100-1).

Яма, в которой они были обнаружены, имеет правильный диаметр по верхнему краю размером 2,76×2,83 м. Глубина ямы от уровня фиксации до дна около 84 см. К дну яма немного расширяется, кроме северо-восточной стенки, которая сужается ко дну. Диаметр ямы по дну около 2,8-2,5 м. По своим размерам эта яма вполне может быть интерпретирована как жилище-полуземлянка. Однако находки в яме были необычными.

В ней были зафиксированы скелеты четырех человек. Они все лежат в центре ямы в скорченном положении, но в разных позах и с разной ориентировкой головой по странам света (Кореневский, Давудов, 2019). 
Скелет № 1. Принадлежит мужчине крупного телосложения. Его биологический возраст в момент смерти соответствовал 35-45 годам (Adultus-maturus). Человек был положен на спину скорчено. Колени, поднятые верх, упали налево. При этом левая нога в согнутом состоянии была поставлена между ног скелета № 3. Ступни скелета № 1 упирались большими пальцами в стенку ямы.

Левая рука была вытянута вдоль туловища. Правая рука была прижата плечевой костью к туловищу, предельно согнута в локтевом суставе так, что локтевая и лучевая кости пересекали грудную клетку и выводили кисть в область правой ключицы и нижней челюсти. По линии таз - череп скелет был ориентирован на запад с небольшим отклонением к северу.

Скелет № 2 перекрывал правую руку скелета № 1. Он принадлежал мужчине в возрасте 25-35 лет, судя по стертости зубов вместе с начальной стадией зарастания черепных швов. Человек был уложен на правый бок с сильным завалом на грудь. По линии таз-череп он был ориентирован на восток. Правая рука его была согнута в локте и кисть находилась под корпусом. Ноги были согнуты в коленных суставах и фиксируют положение «бегущего» человека. Левая рука незначительно согнута в локтевом суставе, находилась между костями ног, а точнее, перекрывала правый коленный сустав и сама была перекрыта коленным суставом левой ноги.

Скелет № 3 принадлежал девушке 1415 лет. О юном возрасте свидетельствуют следующие признаки: полный набор постоянной смены зубов без третьих моляров, уровень окостенения которых находится в пределах 14-15 лет; что подтверждают и размеры диафизов костей. Тело девушки было положено севернее костяка № 1 и вплотную к нему. Ее таз перекрыл кисть и локтевую кость левой руки скелета № 1. Корпус девушки был развернут на левый бок и грудь. Бедренные кости разведены, согнуты в тазобедренных суставах. При этом левое бедро мужчины находилось между ними. Берцовые кости ног смещены, но, скорей всего, ноги девушки были согнуты в коленях.
Позвоночник был прогнут, голова откинута назад. Голова лежала на левом виске. Кости рук были предельно согнуты в локтевых суставах, кисти сведены вместе и находились у лица в молитвенной позе адорации. Между костями ног скелета № 3 и северной стенкой ямы найдены камень и фрагменты сосудов.

Скелет № 4 принадлежал мужчине в возрасте 25-30 лет. Он располагался севернее костяка № 1. Положение костей предполагает, что труп был упакован или связан в компактный блок. По линии таз - череп человек был ориентирован на восток с отклонением к северу. Кости скелета отражают позу сильно скорченного трупа в положении на правом боку с разворотом туловища на грудь. Кости ног сведены вместе, бедренные кости предельно прижаты к области живота. Параллельно им лежат берцовые кости. Пятки буквально вдавлены в таз. Лопатки находятся крыльями наверх. Правая рука была согнута в локтевом суставе, находилась под грудными костями, кистью у колен. Левая рука лежит в слабо согнутом, почти в прямом положении, неестественно отведена назад за спину, пересекает сзади кости таза (рис. 100-1; рис. 100-2). Это захоронение явно указывает, что оно соотносится с пакетированием умершего человека на стороне.

В заполнении ямы ниже костяка № 3 найден камень и крупный фрагмент керамики (рис. 101, 1). Он представляет собой стенку сосуда бурого цвета с обилием ракушки в примеси формовочной массы. Венчик сосуда имеет наклон внутрь. Его высота около 5 см. Диаметр тулова примерно равен 26 см, высота тулова при его реконструкции равнялась бы 20 см. Сосуд, скорей всего, был плоскодонным. На верхней части сосуда имеется налепной орнамент в виде группы из трех вертикальных миндалевидных выпуклин.

Такой же орнамент встречен на фрагменте сосуда похожего облика и формовочной массы с примесью ракушки, найденного в 2012 г. на поселении Тузла-15 (рис. 101, 2) (Сударев, 2013). Эта аналогия позволяет сближать слои поселения Старотитаровско- 
го и Тузла- 15 во времени и по культурному контексту, поскольку здесь и там встречается характерная керамика майкопско-новосвободненской общности, конусы с полым туловом, типичные для псекупского варианта МHO.

Описанные выше позы покойных позволяют прийти к заключению, что мы имеем дело с особым случаем погребальной обрядности и коллективным захоронением. Возможно предположить, что оно состояло из главного костяка и сопутствующих ему костяков.

Главный костяк мужчины возмужалого возраста был положен на спину скорчено головой на запад, с особой позицией рук. Его доминирующее положение в символике обряда похорон связано с тем, что он был перекрыт костяками № 2 и 3.

Левая рука костяка № 1 была вытянута вдоль тела, другая согнута в локте, кистью у лица. К нему вплотную и поверх на бок положили девушку (скелет № 3), так чтобы ее таз касался таза мужчины. Руки девушки были сложены в молитвенной позе кистями у лица. Корпус девушки прогнулся и откинулся назад, голова запрокинулась. Такая динамическая поза предполагает, что смерть настигла девушку именно в могиле в момент похорон.

$\mathrm{C}$ другого бока мужчине положили труп другого мужчины в слабо скорченном положении в «позе бега». К северу от головы главного был помещен труп еще одного мужчины (скелет № 4), уже принявшего ранее смерть на стороне и принесенного к месту захоронения в упакованном состоянии.

Описанная выше погребальная обрядность не согласуется с типичными обычаями захоронения в курганах племен раннего майкопского варианта МНО, ее долинского варианта или новосвободненской группы. Для погребальных традиций этих вариантов характерной была поза покойного человека скорчено на боку, но не на спине. Нет в описываемом погребении охры, часто отмечаемой в майкопских курганных захоронениях.

Важно отметить еще один факт. Погребения на территории майкопских по- селений к востоку от причерноморской полосы-явление необычное. В причерноморских поселениях они встречаются, но редко, как некий показатель местных ритуалов. Так, на поселении Чекон в Анапском районе тоже были зафиксированы останки тел людей (Кореневский, Медникова, Бочковой, 2015. С. 34-42). Погребение в круглой яме человека также найдено на поселении Катусвина Кривица-2, как упоминалось выше. Погребения в круглых ямах также встречены при раскопах поселения Чекон 2018 г. (Кореневский, Юдин, 2019; Юдин и др. 2019, в печати). По всей вероятности такие необычные формы захоронения на поселениях причерноморской полосы псекупского варианта МНО ставят вопрос об их культурной принадлежности и определения важного вопроса, в каком отношении они находились к носителям традиций майкопской керамики на поселениях псекупского варианта МНО.

Интересно также еще одно наблюдение. На поселениях Старотитаровском и Чекон были обнаружены обломки оружия ударного действия, напоминающие чеканы или каменные топоры, имеющие конусовидный клин для нанесения удара (Бочковой, 2013; Бочковой и др., 2012; 2013; Кореневский, 2018а. Рис. 4,3$)$. Такие орудия на памятниках МНО не известны.

Особо показателен для каменных топоров-чеканов округлый обух, совершенно нехарактерный для северо-кавказских топоров медно-бронзового века. Топоры с такой обушной частью зато хорошо представлены находками центральной Европы как типы (Rundnacken äxte) (Zapotockiy, 1992. S. 93 Abb. 24).

Все это заставляет думать, что публикуемое коллективное погребение и материалы поселений Старотитаровское и Чекон позволяют ставить вопрос о необходимости дальнейшего изучения подобных случаев в погребальной практике населения причерноморской части псекупского варианта МНО и специфике обнаруженных на них находок.

Поселение Орлов Ерик. Поселение было раскопано в 2013 г. по открытому листу 
М.Б. Рысина. Оно находится у г. Апшеронска Краснодарского края. Раскопки были связаны со строительными работами. Памятник находится вблизи одноименного ручья - правого притока реки Пшеха. На поселении зафиксированы остатки двух жилищ, окруженных хозяйственными ямами. Хозяйственные ямы (всего 41) зафиксированы как внутри жилищ, так и в междужилищном пространстве. На поселении открыты ямы-очаги. Эти ямы, определяемые как очажные, имеют слоистые стенки с глиняной обмазкой со следами обжига, большое количество углей, а также заполнение в виде крупных фрагментов керамических сосудов, возможно, искусственно выложенных вокруг стенок ямы. Кроме того, в каждом из очагов найдены глиняные конусы с поперечными отверстиями, так называемые «очажные подставки». На поселении Орлов Ерик обнаружены керамика, зернотерки, кремневые наконечники стрел и вкладыши серпов, а также иные виды каменного инвентаря. Поселение, судя по формам конусов, относится к псекупскому варианту МНО.

\section{Прикубанъе нижнее и среднее}

Серегинское поселение. Поселение расположено у хут. Чернышов Шовгеневского района Краснодарского края. Раскопки проводились К.А. Днепровским и Л.А. Яковлевым в 1984-1987 гг. Раскопанная площадь составила $70 \mathrm{M}^{2}$.

Постройка 1 была наземным строением, вероятно, округлой формы. Сохранившаяся площадь имела размеры $7 \times 6$ м, то есть более 42 м. Вся площадь жилища покрыта слоем горелого турлука. Сохранились остатки стен из жердей, опорный столб для перекрытия. Выявлены остатки глинобитного пола и пола с утоптанным уплотнением. В жилище найдены остатки двух печей и двух очажных площадок, много фрагментов керамики. О находках костей животных информации нет (Днепровский, Яковлев, 1988. С. 89-99) (рис. 102, рис. 103).

Постройка 2 сохранилась не полностью и выявлено по развалу турлука 4,5×1,4 м. Пол строения прокален. В нем выявлена очажная яма диаметром 60 см с углями и золой.

Постройка 3 выявлено по развалу турлука $3,4 \times 2,6$ м. Пол строения имеет прокал.

Постройка 4 выявлена по развалу турлука $5,8 \times 7,7$ м.

По мнению К.А. Днепровского, постройки 1 и 2 могли быть жилищами, а постройки 3 и 4-хозяйственными помещениями (Днепровский, 1991. С. 3-17). На поселении также выявлены девять ям хозяйственного значения. Диаметры ям 1,33-1,15 м, глубина от поверхности до -80 см. В них найдена керамика, угли, кости животных.

В одной яме обнаружены горелые прутья, бронзовый нож раннемайкопского типа с остатками кожаных ножен, кремневый нож на пластине (Днепровский, 1991. С. 6).

Чишхо поселение. Поселение расположено у аула Теухабль на южном берегу Краснодарского водохранилища. А. Д. Резепкин называет открытые им объекты жилищами и ямами.

Жилище 1. Наземное. Все перекрыто развалами турлука площадью 5,6×5,3 м. Внутри под турлуком в центре жилища была яма диаметром около 1,2 м, глубиной 0,2 м. Яма была заполнена углем и обломками керамики (Резепкин, 2004. С. 422-429).

Жилище 2 наземное. Выявлено по развалу турлука. Турлук покрывает площадь $3,8 \times 2,7$ м. Турлук перекрыл три ямы размером 1,3 м, 1,1 м, 1 м. Глубина ям до 1 м от уровня дна жилища. В ямах найдена керамика (Резепкин, 2004. С. 429).

Жилище 3 оказалось разрушенным (Peзепкин, Лионне, 2007).

Жилище 4 выявлено по округлому перекрытию турлуком диаметром 5,45 м. Под перекрытием выявлена яма диаметром 1 м и глубиной 1 м от уровня жилища. Яма впущена в материк на 20-30 см (рис. 104).

Жилище 5 перекрыто развалом турлука диаметром около 3,4-3,54 м (рис. 101).

Жилище 6 перекрыто развалом турлука овальной формы размером 4,9×4,3 м. Под развалом турлука отмечена яма диаметром 1,2 м. Яма завалена кусками турлука (Резеnкин, Лионне, 2007. Рис. 48) (рис. 105). 
Жилище 7 перекрыто развалом турлука, который сохранился фрагментарно. В площади жилища отмечена яма размером 1,5 м с обломками обожженного турлука и фрагментами керамики (Резепкин, Лионне, 2007. Рис. 48) (рис. 105).

Пхагуапе поселение, находится в 2 км к западу от пос. Чишхо. На нем найдена хозяйственна яма (Резепкин, 2004. С. 430).

Хут. Городское поселение. Теучежский район Краснодарского края (раскопки Резепкина А.Д.).

Жилище 1 (№ 5, номер жилища по работе А.Д. Резепкина) было округлым в плане. Оно находится под развалом турлука диаметром 7-7,5 м. Под слоем турлука найдены развалы керамики, а также две ямы. Диаметр одной очажной ямы с углем и керамикой равен 1,2 м. Диаметр другой ямы 3 м с завалами турлука по внешнему краю и 2 м по дну ямы (Резепкин, Лионне, 2007. С. 6, рис. 2).

Жилище 2 (6) круглое в плане было перекрыто развалами турлука диаметром $7-7,5 \mathrm{~m}$.

Жилище 3 (7) круглое в плане было перекрыто развалами турлука. Развал отражает округлую форму диаметром около 6,6 м. Он перекрыл яму диаметром около 1,3 м по внешнему краю, глубиной 0,6 м в материке $(P e$ зепкин, Лионне, 2007. Рис. 10).

Жилище 4 (5) представлено развалом турлука диаметром около 6 м. В центре жилища находилась яма с остатками горения (очаг). Ее диаметр был немногим более 1 м. Другая яма диаметром по верхнему краю 3,1 м была перекрыта развалами турлука в северо-западной части жилища. Турлук составлял верхний уровень заполнения ямы (рис. 106, 3).

Пшикуйхабль поселение. Памятник расположен вблизи аула Пшикуйхабль. (Раскопки А.Д. Резепкина).

На нем выявлено 17 остатков жилищ, судя по развалам турлука. Относительно целым было жилище 12 (Резепкин, Лионне, 2007. Рис. 10).

Жилище 1. Развал турлука сохранился фрагментарно (Резепкин, Лионне, 2007. Рис. 13). Находок нет.
Жилище 2. Развал турлука размыт. Под ним обнаружена яма с фрагментами керамики. Диаметр ямы 1,2 м (Резепкин, Лионне, 2007. Рис. 14).

Жилище 3 сохранилось фрагментарно (Резепкин, Лионне, 2007. С. 19).

Жилище 4 сильно размыто и выявлено по развалам турлука (Резепкин, Лионне 2007. C. 19).

Жилище 5 полностью размыто.

Жилище 6 сохранился только фрагмент перекрытия из турлука. Под ним найдены фрагменты керамики (Резепкин, Лионне, 2007. C. 19).

Жилище 7 сильно размыто. В его площади найдена яма диаметром 1,3 м, забитая с самого верха турлуком и несколькими фрагментами керамики (Резепкин, Лионне, 2007. C. 19, 20).

Жилище 8 сильно размыто, сохранились лишь фрагменты турлучного покрытия.

Жилище 9 совершенно размыто. Фиксируется по развалам турлука и керамики.

Жилище 10 сильно размыто. Зафиксирована неглубокая яма с фрагментами керамики. Размеры ямы около 1 м. Точнее установить сложно.

Жилище 11 полностью разрушено. Фиксируется по развалу турлука.

Жилище 12 сохранилось хорошо, имеет форму овала $7 \times 6$ м. Перекрыто развалом турлука. Под ним отмечена яма, забитая рухнувшим турлуком. Диаметр ямы 60 см и глубина 60 см.

Жилище 13 фиксируется только по переотложенным кускам турлука.

Жиище 14 не сохранилось. Фиксируется по остаткам развала турлука. В площади жилища отмечена яма. В ней найдены кости животных и фрагменты двух сосудов.

Жилище 15 не сохранилось. Установлены только остатки ямы диаметром около $1 \mathrm{~m}$, заполненной турлуком.

Жилища 16 и 17 практически не сохранились (Резепкин, Лионне, 2007. С. 20).

Поселение Новосвободненское. Заканчивая перечень поселений Прикубанья, хотелось бы отметить памятники, на которых следов построек не выявлено или сведения о них подробно не введены в научный оборот. Таково 
поселение Новосвободненское в предгорьях Адыгеи в урочище Клады. Оно раскапывалось А.Д.Резепкиным в течение нескольких сезонов, начиная с 1990-1991 гг. Автор раскопок отмечает найденную им в начале 1990-х годов разрушенную постройку с турлучной стеной толщиной 10 см, длиной 2,2 м и высотой 12 см. Поверхность стены и пола была покрыта слоем белой глиняной обмазки. На полу, примерно посередине жилища, по мнению автора раскопок, был найден очаг. Он представлял собой углубление диаметром 0,7 м. Углубление было завалено обломками керамики и обожженными кусками кремня. О следах горения, прокала почвы в этом углублении не упоминается (Резепкин, 2008. С. 156; 2012. С. 51; 2013). Поэтому такое углубление, на мой взгляд, можно принять за яму хозяйственного или ритуального значения.

Усть-Джегутинское поселение. Другим памятником бытового или иного культурного использования является Усть-Джегутинское поселение. Оно расположено на окраине г. Усть-Джегута на правом берегу р. Кубани. Напротив места расположения поселения располагались курганы, содержащие комплексы раннего майкопского варианта МНО. Они раскапывались А.Л. Нечитайло (Нечитайло, 1978; Мунчаев Р. М., Нечитайло А. Л., 1966)

С 2004 года здесь регулярно проводись раскопки А.Д. Резепкиным. По его отчетной статье им было вскрыто 316 м² культурного слоя и найдено более 3000 фрагментов керамики (Резепкин, 2013a, С. 40-70). На памятнике не было зафиксировано ям, каких-либо строений, очагов. О бытовых объектах может свидетельствовать очажная приставка, непременный атрибут майкопских жилищ, но окружающий ее контекст не ясен. О коллекциях найденных костей информации в статье А.Д. Резепкина нет. Усть-Джегутинское поселение датируется второй-третьей четвертью IV тыс. до н.э. (3640-3550 BC; 3640-3360 ВC) по костям животных (Кореневский, 2011. С. 29). Почему на Усть-Джегутинском поселении не было встречено следов построек, для меня вопрос открыт.

\section{Район Кавминвод и Терский регион}

Аликоновское-1 поселение. Поселение расположено в пригороде г. Кисловодска и пос. Аликоновки на берегу древней балки. На поселении Аликоновское-1 обнаружена разрушенная строительной траншеей овальная яма размером около $3,3 \times 2,5$ м с заплечиком. В ней была вырыта малая яма с длиной по одному из диметров около 1,2 м. Рядом находилась малая яма с продуктами горения (красной крошкой). Глубина обнаружения ям около -71 - -72 см. Малая яма в яме с заплечиками была завалена костными останками и угольками. В малой яме среди обгорелой крошки найдены фрагменты керамики и перевернутый вниз головкой конус с отверстием (Кореневский, 1998) (рис. 107).

Галюгаевские поселения. Поселение Галюгаевское 1 расположено на левом берегу р. Терек восточнее ст. Галюгаевской, в открытой местности древней речной долины, примыкает к западному окончанию Прикаспийской низменности. Поселение раскапывалось в 1965-1991 гг. Всего на нем открыто три строения на пос. Галюгаевское 1 (рис. 108). Примерную площадь наземных построек по остаткам конструкций возможно установить для ряда построек.

Жилище 11988 г.-наземное строение округлой формы. Контур определяется по кольцевидному развалу турлука (рис. 109). Очаг устроен под северо-восточной стенкой (рис. 110, 3). Диаметр жилища 7 м. Площадь 35 м². В площади жилища найдены зернотерки (рис. 110, 1, 2).

Жилище 21989 г. округлой формы с размером $10 \times 12$ м. Площадь строения около

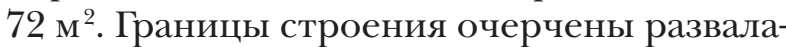
ми турлука. Зафиксированы центральный очаг и четыре очажных места под южной, западной, северной и восточной стенками жилища. В жилище не было отходов быта, костей, углей. Рядом с жилищем находилась яма диаметром 1 м, заполненная золой (рис. 111).

Жилище 31991 г. имеет контур по округлой выкладке из черепков и турлука. Диаметр контура около 5,2 м. Площадь строения 25 м² $^{2}$ В площади строения найден наземный 
очаг (рис. 112, 1; рис. 113, 1) и яма (рис. 113, 2), забитая черепками керамики диаметром около 1 м. Зачистка уровня пола проведена на глубинах -58, -56 - -62 см. На этих глубинах над ямой были расчищены обломки турлука. Обнаружение ямы произошло на этапе дополнительной подчистки уровня пола строения на глубинах $-71,-75$ см, когда находки внутри жилища уже были выявлены (Кореневский, 1995; Кореневский, 2004. С. 13; С. 138 , рис. 10,3$)$. (Примечание 2). Дно ямы находится на глубине -106 м.

Рядом с жилищем 3 на расстоянии около 1 м на юго-восток была найдена яма с керамикой и костями животных.

Жилище 1 на поселении Галюгаевское III было открыто в 1991 г. Оно определено по находкам развалов керамики зернотерки и слою мелкой речной гальки, явно принесенной и выложенной в данном месте. Площадь, занятая находками, занимала около 4 м² (Кореневский, 1995) (рис. 114).

Стодеревское поселение. В 2008 г. в той же самой зоне «галюгаевских» всхолмлений у соседней станицы Стодеревской было открыто еще одно майкопское поселение. Оно находилось в 5,4 км южнее станицы. Поселение раскапывалось в 2008 г. С.Б. Березиным (Березин, 2009) (рис. 115).

Судя по подъемному материалу выброс керамики из грунта под влиянием распашки составил с севера на юг 25-30 м, с востока на запад 100-120 м, общей площадью 2500-3500 м². На поселении был заложен раскоп 20×20 м площадью 400 м². Находки начали встречаться в пахотном слое и на глубине -20 - -25 см ниже слоя пахоты (примерно -60--80 см от поверхности). По цветовой гамме культурный слой никак не выделялся. Он залегал в каштановой почве светло-желтого цвета. Глубина раскопок достигла 1 м от поверхности. Следов залегания карбонатов не отмечено. В пределах раскопа фиксировались отдельные скопления костей животных, крупного и мелкого рогатого скота.

На поселении найдены четыре ямы.

Яма 1 округлой формы имела размеры $2,32 \times 2,4$ м, зафиксирована на глубине -54 см. Дно находится на глубине -76 см.
В ней найден венчик крупного сосуда и несколько мелких фрагментов керамики, каменный терочник, обломок очажной подставки с округлой головкой и отверстием. На верней части этого культового предмета (Кореневский, 2013) нанесены врезные линии. Среди керамики отмечены обломки плоских доньев, цвет керамики коричневый и красный. Поверхность подлощена и заглажена.

Яма 2 округлой формы диаметром $2,44 \times 2,68$ м. Зафиксирована на глубине -59 м. Дно находится на глубине -0,99--1,12 м. Находки составили обломки керамики, в том числе охристого цвета сосуда с ручкой-ушком.

Яма 3 округлой формы, зафиксирована на глубине $-0,70--0,75$ м. Размер ямы $1,23 \times 1,16$ м. Дно на глубине $-0,99--1,0$ м. В яме найден каменный скребок из сланца (?) серого цвета.

Яма 4. Уровень фиксации - 0,69-0,75 м. Дно на глубине -0,91--0,93 м. Размеры ямы $1,06 \times 1,17$ м. В яме найдены только несколько фрагментов керамики.

В целом находки на Стодеревском поселении близки находкам галюгаевских поселков. Обращает на себя внимание присутствие лощеной охристой керамики с красными линиями разводов, великолепная чернолощеная керамика: такова миска и сосуд с ручкой-ушком на сгибе горла, обломок сдвоенного сосуда, а также очажные подставки. Одна из них имеет на головке такие же продольные насечки, как и на подставке из Галюгаевского 1 поселения (рис. 115, 7).

Глубина обнаружения ям на Стодеревском поселении соответствует глубине верхних отложений Галюгаевского поселения 1. Даты по кости Стодеревского поселения: Ki-16130 $4540 \pm 80$ BP 3370-3090 BC; Ki-16131 $4490 \pm 90$ BP 3350-3080 BC.

Описание построек и ям МНО предпринимали различные специалисты, раскапывающие ее бытовые памятники, включая автора этих строк (Кореневский, 1995, 2004): А.В. Яковлев, К.А. Днепровский, А.Д. Резепкин, Е.Н. Булах и иные, чьи работы упоминались выше. В целом данных о майкопских постройках пока немного. Это 
заставляет придерживаться самых общих и первичных определений с учетом локальных особенностей поселений.

Майкопские постройки были наземными сооружениями, землянками и полуземлянками круглой формы. При этом часть из них имела ямы в площади строения. Постройки возводились из прутьев, жердей, кольев и столбиков, планок и, надо думать, с легким покрытием крыши из веток. На поселении Тузла-15 следы очага были обнаружены только в яме-полуземлянке постройки 42015 г. По всей видимости, отсутствие очагов внутри ям-полуземлянок можно связать с жарким климатом того времени и правилами безопасности обитания в такой постройке. Огонь разводили вне постройки. Так, очаг (печь) для приготовления пищи за пределами жилища сейчас можно наблюдать у жителей жаркого климата без снежных зим в Ленкоранской низменности (Азербайджан).

Ступеньки в яме-полуземлянке могли служить своего рода полочками или примыкать к входу. Жилища-полуземлянки с полочками зафиксированы при раскопках на поселении Техут Р. Торосяном в 1966 г. Поселение Техут расположено недалеко от г. Эчмиадзина в Армении. Оно датируется серединой IV тыс. до н. э. (Торосян, 1976). По керамическому комплексу Техут относится к лейлатепинской культуре.

На поселении было найдено более десятка жилищ. Р.М. Торосян описывает их как землянки или полуземлянки. Строения имели круглую форму диаметром 2,6-3 м. Они были углублены в грунт на $0,7-1,6$ м. Их стены обкладывались земляными кирпичами по всему периметру. В хижинах были зафиксированы очаги, зернотерки, подпорки под дверь, пристроенные к стенам полочки или ступеньки. Вблизи от построек находились хозяйственные ямы, заполненные золой (Торосян, 1976. С. 24, рис. 2; С. 25, рис. 3; С. 39 , рис. 6 ; С. 40 , рис. 7$)$.

Директор Эчмиадзинского музея Анжела Тадевасян восстановила одно из жилищ по описанию из дневника полевых работ Р. М. Торосяна. Жилище имело вид правильной окружности. Высота его стен из зем- ляных кирпичей достигала 80 см. Диаметр круглого контура жилища равнялся 3 м. На дне жилища в центре находился очаг округлой формы диаметром около 0,5 м. Жилище имело ступеньку или полочку, сооруженную вдоль стенки. В жилище присутствовали зернотерки, песты, несколько сосудов в виде кубков с высоким расширяющимся горлом. В комплекс находок, связанных с жилищем, входит пяточный камень от двери наружно внешней части строения (рис. 116).

Жилища в виде землянок или полуземлянок были открыты Т. Ахундовым на поселении лейлатепинской культуры Алхантепе на Ленкоранской низменности в Азербайджане. Они имели круглую или прямоугольную форму. Диаметры круглых жилищ равнялись 1,75-2,4 м. Они уходили в грунт на глубину -0,3 - -04 см, до -1 м (Ахундов, 2014). Такие же жилища зафиксированы на поселении Беюк Кесик лейлатепинской культуры (Мусеибли, 2007). Множество ям хозяйственного значения было открыто А.И. Джавахишвили на поселении лейлатепинской культуры Бериклдееби в Грузии (Глонти, Джавахишвили, 1987; Кипиани, 1997)

Историческая этнография передает немало сведений о землянках и полуземлянках первобытных народов. Г. Шурц упоминает жилища, погруженные целиком или частично в землю у племен тропической Восточной Африки (тембы) (Шури, 1907. C. 426). Некоторые тембы имели выкопанный в земле вход.

Наземные хижины круглой формы веток, кольев, покрытые травой, листьями были широко распространены в тропической Африке, например у зулусов (Тейлор, 1939. С. 125 рис. 40). (Интернет-ресурс. Жили ща масаев) (рис. 117).

Следующим аргументом в интерпретации ям на поселении Тузла-15 могут служить примеры раскопанных жилищ на поселениях псекупского варианта МНО с турлучными покрытиями, которые достаточно хорошо очерчивают площадь постройки, таких как Чишхо, Пшикуйхабль (Резепкин, 2004; $P e$ зепкин, Лионне, 2007). Внутри построек были 
зафиксированы ямы с обломками керамики и очажными отходами. (Подробнее см. ниже). Такие находки позволяют рассматривать ямы в отдельных случаях как конструктивные особенности майкопских наземных построек.

Естественно, не все ямы на майкопских поселениях являются деталями строений. Ямы размеров до 1-1,3 м для складирования золы могли сооружаться рядом с жилищами, но их связь с постройками, как видим, также имела место.

Заполнение ям строений на пос. Тузла-15 очень интересно. Обнаруженные в них черепки не представляют целые сосуды. Это керамический бой разных керамических изделий, специально брошенный в яму. Наряду с черепками в яму бросали кости животных. Некоторые из них расколоты и свидетельствуют об использовании костей во время трапезы.

Кучкой на дно постройки могли положить створки раковин-также остатки трапезы. Иногда в яму попадали обломки зернотерок или иных каменных орудий. Непременной находкой является обломок очажной приставки - символа майкопского жилища. Все эти остатки позволяют полагать, что крупные ямы - комплексы майкопских построек на поселении Тузла-15 могли специально забрасываться отходами пищи (или отходами поминального пироторжества) и быта.

За такими действиями мог прослеживаться культ возрождения, символом которого служили черепки сосудов и кости животных. Такие же следы ритуального забрасывания ямы жилища наблюдаются на поселении Аликоновское-1.

Совершенно необычным выглядит заполнение постройки 4 золой. Ее принесли в большом количестве со стороны и специально бросили в заброшенное помещение. Аналог такого действия находит многочисленные примеры на поселении Чекон в 2018 г. (раскопки А.И. Юдина) (Кореневский. Юдин, 2019). Интерпретацию такого действия желательно произвести вместе с изданием материалов раскопок поселения Чекон 2018 г.
В настоящее время наблюдается следующая локализация особенностей майкопских строений.

Для Причерноморской зоны, памятников псекупского варианта, наиболее часто отмечается тип полуземлянки. Слабо прослеживаются опорные конструкции, скорей всего, использовались каркасные устройства. Наземных жилищ, покрытых сплошь турлуком, не прослеживается, но их использование в Причерноморской зоне не исключено.

Для низовий и среднего течения Кубани распространены были постройки с обмазкой их глиной (турлуком). Турлук покрывал крышу строения.

В Терском районе, на востоке ареала МНО, раскопаны наземные жилища с обмазкой стен по периметру и с очагами внутри (Галюгаевское 1 поселение). Есть основания говорить о небольших наземных строениях без турлучной обмазки (Галюгаевское III поселение). Возможно, на Стодеревском поселении использовались полуземлянки. Такие жилища были свойственны племенам майкопского и псекупского вариантов МНО.Аналогии строениям из веток и прутьев круглой формы с обмазкой по периметру глиной или с обмазкой глиной крыши отмечаются у африканского населения, племен Кении, племен Наталя, Мозамбика, Зимбабве (рис. 117).

Пока нет точных данных о жилищах долинского варианта МНО. Скорей всего, они были наземными и легкими, из прутьев, веток и колышков. Неясен вопрос и о жилищах новосвободненской группы (Резепкин, 2012).

Площади построек возможно вычислить по развалам тулука, там где имели место турлучные конструкции. На пос. Галюгаевское 1 площади жилищ выявлены от 25,

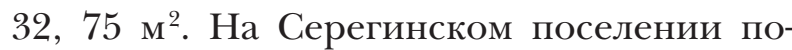

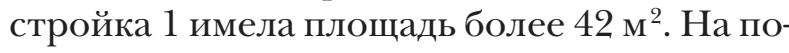
селении Чишхо турлук покрывал площади жилищ около - 20-25 м². Ямы предполагаемых жилых построек полуземлянок имели площадь от 4 до 9 м². Но полную обитаемую площадь полуземлянки вычислить трудно, так как ее наземная часть могла не оставить следов. 
Общей традицией майкопских племен было сжигание своих забрасываемых жилищ. Характерным атрибутом построек были глиняные конусы-приставки к очагам.

По своему внешнему виду майкопские наземные строения могли походить на хижины племен Восточной Африки, приспособленные к жаркому климату, как, например, жилища зулусов (рис. 117). Обмазка турлуком стен жилища или покрытие турлуком крыши создавали внутри строения более прохладные условия в жарком зное, были способны уберечь от промокания во время проливных дождей и сильного ветра.

Возможно ли проследить социальное расслоение по находкам в жилищах? Видимо, отчасти, да. Так, особый престиж строений и их обитателей отражают оставленные в жилищах крупные развалы чанов, пифосов, обломки кубков из теста без минераль-

\section{Примечание 2}

Постройка 3 на поселении Галюгаевское 1. Работы на поселении Галюгаевское 1 в 1991 г. сконцентрировались на раскопе 6, расположенном западнее раскопов 1988 и 1989 гг. Место для организации раскопа было выбрано по разведке в квадрате A-1. Площадь и конфигурация раскопа развертывались по мере расчистки путем прирезания отдельных новых квадратов и целых линий квадратов, стремясь охватить всю площадь скопления находок и оконтурить ее относительно новых квадратов разряженными или пустыми зонами.

В итоге раскоп приобрел очертания квадрата $10 \times 10$ м. В его центре находится скопление артефактов: керамики, каменных орудий, расположенных как бы по дуге окружности. Глубины, на которых находились черепки, приблизительно варьируют от - 0,52 м до -0,76 м. Расчистка находок велась сплошной площадью, «на горизонт». Все черепки и другие артефакты оставлялись на месте до полной фиксации находок ных примесей. Подобные находки встречены в жилище 1 на Серегинском поселении и в жилищах 1, 2, 3 на Галюгаевском поселении. Находки в жилищах Галюгаевского поселения зернотерок позволяют думать, что в них шли трудовые процессы.

Вместе с тем поиск различий в богатстве построек майкопских поселений методически очень сложен, так как население могло использовать свои постройки по-разному, например, как места для производства, сезонные строения, объекты только для сна и тому подобное. При покидании жилища ценные вещи могли из него изыматься. Поэтому данная проблема во многом сейчас остается открытой. На поселении Тузла-15 впервые встречены следы ритуала намеренного забрасывания постройки золой. Он требует дальнейшего изучения и уточнения вопроса об отношении носителей МНО к своим постройкам и связанным с ними культам и верованиям.

в раскопе. Отчетливо прослеживался наклон уровня залегания черепков согласно общему скату поверхности галюгаевского гребня к северо-востоку. Всего в раскопе было раскопано 25 квадратов. Основные развалы артефактов сосредоточены в кв. 1, $5,8,9$ на площади $6 \times 8$ м.

В центре скопления в кв. 9 находился развал крупных кусков обожженной докрасна глины. Подобные фрагменты ранее встречались нам в жилище № 21989 г. и были связаны с очагом. Это дало основание думать, что в раскопе № 6 мы наткнулись на нечто подобное.

Развал предполагаемого «очага» имел в длину 0,9 м и ширину 0,4 м. После снятия кусков обожженной глины мы не обнаружили под ними и вблизи углей, золы и прокала грунта. Почва вокруг скопления была лишь более темной, но не походила на отчетливый след заполнения ямы. Правда, в этом случае можно предположить, что заполнение однородной каштановой почвы в каштановой 
почве может и не оставить традиционного «пятна», давая о себе знать только несколько отличной гидропроводимостью.

Проверочная прокопка на два штыка не обнаружила артефактов. Западнее скопления обломков обожженной глины в кв. 15 был расчищен развал сосудов. В его пределах хорошо прослеживались обломки крупного шаровидного горшка, сделанного из глины без различимых на глаз примесей (керамика 1 класса) и развал пифоса с огнестойкими примесями в тесте (2 класса).

С севера, запада и востока от развалов обожженной глины предполагаемого очага расположение развалов артефактов очерчивает дугу окружности примерно диаметром 4,8 м. Внутри нее отмечается повышенное насыщение находками, главным образом разбитыми черепками, каменными орудиями и иногда кусочками обожженной глины. Край дуги отмечен фрагментами сосудов, каменных орудий, среди которых имеются зернотерки.

С запада этот бордюр как бы включает развал сосудов в квадратах 1, 5. В кв. 9 в линию бордюра вписан крупный каменный терочник. В линии дуги находок располагается зернотерка. Южнее нее находятся обломки глиняных конусов и прослеживаются небольшие пятна прокала диметром 5-10 cм.

Далее на юг в кв. 18 лежат два обломка зернотерок. Внутри зоны окружности по линии квадратов 1-23 наблюдаются залегания черепков более насыщенные по сравнению с южной периферией раскопа. Линии квадратов вдоль бортов так же слабее насыщены артефактами, чем центральные квадраты.

В итоге можно сделать вывод, что раскоп № 6 располагается на месте когда-то стоящего здесь жилища. Оно было наземным, со стенами, сделанными из прутьев, не оставляющим после себя археологических следов. Следов от обмазки, таких как в жилищах № 1 и № 2 на Галюгаевском I поселении здесь не встречено. Обмазка, видимо, не была интенсивной.

Зафиксированный порядок расположения артефактов в виде полуокружности, возможно, указывает на гипотетические границы постройки. Видимо, рассеиванию предметов мешала какая-то преграда - стены округлой постройки диаметр жилища, если опираться на размеры дуги, диаметр постройки был близок к 5 м.

Строение в древности было уничтожено пожаром, Среди черепков встречались фрагменты ошлакованной глины, иногда спекшиеся с землей.

После фиксации находок раскопа № 6 на чертеже и фотофиксации мы приступили к снятию находок и проверке площади раскопа. В этот момент было обращено внимание на выступающий из земли камень в кв. 17 на глубине $-0,55--0,58$ м .

Расчистка почвы вокруг него дала любопытную картину. Рядом с первым фрагментом каменного орудия-зернотерки лежало еще два обломка. Общий диаметр «кучки» камней составил 15 см. Нижний уровень залегания камешков доходит до $-0,68$ м. Скопление камней напоминало мне ситуацию в жилище № 1. Можно было думать об этих обломках, как о забутовке небольшой ямы под столбик (центральный столб). От уровня строения ямка была заглублена на 10-18 см.

Расчистка продолжалась, принося все новые и новые результаты. Были выявлены развалы крупных шаровидных сосудов (пифосов), брошенный на них кусок обожженной глины, чуть севернее следы прокала. Далее был выявлен крупный развал керамического боя. Верхний его уровень находился на глубине -0,59 - -0,75 м. В скоплении отмечены обломки, которые лежали ниже, на глубине - -0,86--0,92 м обнаружено каменное орудие-отбойник из гальки.

Скопление черепков приобрело устойчивые овальные контуры размером $0,8 \times 0,6$ м. Нижний уровень фиксации черепков находится на глубине --0,9, - 1,06 м. Очевидно, тут лежал крупный фрагмент горшка с огнестойкими примесями. Здесь были отмечены зубы овцы. Открытое скопление находок в кв. 1 представляло мусорную яму, вырытую в зоне постройки.

В кв. 24 с внешней стороны предполагаемого жилища на глубине $-0,66$ м 
зафиксирована еще одна мусорная яма, диаметром около 0,5 м. Глубина скопления находится на уровне - $0,66,-0,76$ м примерно на 10 см ниже уровня постройки. В яме были обнаружены кости животных и черепки.

Юго-западнее скопления расчищено два песта из терской гальки. В южной периферии раскопа в кв. 7 на глубине слоя жилища обнаружено скопление черепков сероглиняного шаровидного сосуда 1 класса и черепков от горшка класса 2. Разброс черепков составил около 2 м и был отмечен в кв. 2.

Среди периферийных квадратов раскопа, находящихся у ее бортов, находок найдено очень мало. В кв. 22 были расчищены 2 небольших пятна прокала диаметром 10 см. В кв. 24 на глубине -0,76 м найдены обломки глиняного конуса, лежащие друг от друга на расстоянии до 0,6 м.

В кв. 20 на глубине -0,62, -0,6 м лежало каменное орудие и черепок. Отдельные фрагменты керамики встречались у западного борта раскопа в кв. 6 на глубине $-0,52$, а также в кв. 11 и 12. В кв. 22 найден кусочек подмазки прямоугольной формы.

После полной фиксации находок площадь жилища была прокопана на 3 штыка. На стыке кв. 17 и 22 под «бордюром артефактов» зафиксирован черепок на глубине -1 м. Он отделен стерильной прослойкой 0,4 м от верхнего уровня.

При пристальном осмотре черепков внутри жилища и их зарисовке на общий план мной было обращено внимание на то, что некоторые их них принадлежат одним и тем же сосудам, которые удалены друг от друга на значительное расстояние. Процесс перемещения шел от центра к периферии предполагаемого строения. Так, крупный фрагмент миски с ушком 2 класса керамики с отверстиями в бортике находился в кв. 18, а другие фрагменты этого же сосуда помещены в кв. 9, южнее развала «очага». Куски крупной лощеной миски 1 класса керамики отмечены в кв. 8 и 17. Они лежали на расстоянии 3 м.

Части еще одного горшка зафиксированы на удалении 2 м друг от друга. Таким образом, внутри жилища шел процесс (естественный? антропогенный?), приводивший к дисперсии обломков керамики по площади.

Мусорная яма внутри жилища была не связана с зоной обитаемого пространства. Показательно то, что ее даже не было заметно на уровне залегания черепков на гипотетическом «полу» строения. Мне представляется, что она была вырыта и забросана мусором до того времени, как на данном месте возникло новое строение. По случайным обстоятельствам на место бывшей ямы пришлась ямка под центральный столб, укрепленный забутовкой из кусков каменных зернотерок. Таким образом, жилище № 31991 г. дало первые интересные свидетельства о соотношении ямы внутри жилища и самого жилища на Галюгаевском поселении.

Культурный слой жилища 3 был несколько выше уровня обнаружения жилища 1 и жилища 2. Оно залегало на 50-60 см от репер-центра. Жилище № 2 на глубине $-0,78$ м. Жилища № 1 0,7-0,8 м.

Постройка 1 на поселении Галюгаевское III. Поселение Галюгаевское III было открыто в 1989 г. Памятник представлял собой типичный «галюгай»- невысокий продолговатый холм, тянущийся с востока на запад, до 1 км в длину. На возвышенности располагается курганная группа. Поверхность всхолмления интенсивно распахивается. В 1989 г. мы собрали здесь разнообразную коллекцию майкопских черепков и фрагментов человеческих скелетов - следы разрушения культурного слоя поселения и погребальных комплексов в курганах. Разведочные шурфы 1989 г. обнаружили крупную яму-мусорник. В 1991 г. мы ставили цель продолжения разведки культурного слоя пос. Галюгаевское III. Раскопки сконцентрировались между курганами 4 и 5 . К востоку от кургана 4 на 17,5 м был заложен раскоп площадью в 36 м $^{2}$.

Комплекс 1. Начало работ было связано с кв.І. Они дали развал сосуда с огнестойкими примесями. Культурный слой в кв. 1 лежал не глубоко. Черепки были найдены на глубине -0,43 м от поверхности. Расширение раскопа по принципу охвата культурного комплекса, скопления керамики привело к открытию обитаемой в древности площади. 
В кв. 1 и 2 залегал развал нескольких горшков, преимущественно с огнестойкими примесями класса 2. Редко попадались черепки охристой лишенной керамики без огнестойких примесей.

В квадратах 1, 5, 8 было встречено множество галек. Они отличаются близкими размерами, имея в диаметре около 5 см. К бортам раскопа интенсивность насыщения галькой резко убывает. Среди особых находок следует отметить фрагмент зернотерки, угловой фрагмент глиняной обмазки и два обломка крупных пифосов.
Скопление артефактов в раскопе 1 на Галюгаевском поселении III видимо отражало следы когда-то стоящего здесь наземного легкого жилища, пол которого был усыпан терским песком с включениями гальки.

Чтобы проверить нашу гипотезу, мы вырыли два контрольных шурфа $2 \times 2$ м и глубиной $-0,6$ м, расположив их по диагонали от юго-восточного угла раскола. В них не оказалось ни гальки, ни черепков. Следовательно, наше предположение о связи артефактов в раскопе 1 и скопления гальки с археологическим комплексом находит подтверждение. 


\section{ГЛАВА 10. \\ Палинологические исследования}

Палинологические определения на поселении Тузла- 15 были выполнены Е. А. Спиридоновой, включая составленные таблицы (табл. 10-12). Предварительные результаты этой работы начали появляться в печати. (Кореневский С.Н., Спиридонова Е.А., Сударев Н.И., 2019). Исследования по изучению палеоботанических образцов были получены по отборам проб в шурфе 12012 г., квадрате 12014 г. и в квадрате 22014 г. Пробы для анализа собирались мной из бортов квадратов через 10 см. Верхние пробы располагались под нижним уровнем распашки, нижние происходили из почвы, пронизанной карбонатными отложениями, и из более глубокого материкового слоя.

Рельеф возвышенности Тузла- 15 напоминал невысокий холм, поверхность которого была наклонена. Поэтому верхняя граница появления карбонатов в разных квадратах могла быть близкой, но не равнозначной.

Заключения по колонке шурфа 12012 г. лишь обозначили исследуемую проблему. Они отразили общую закономерность расположения в почве культурных останков. Так, уровень распашки имел нижнюю границу на глубинах $-0,55--0,6$ м (образец 1). Предполагаемый культурный слой занимал толщу в размерах от $0,55-0,6$ м до глубины $-0,75--0,8$ м (образцы 2-5). При этом четко его нижняя граница не фиксировалась. С глубин -0,80 - -0,85 м (образец 6) начинали появляться карбонаты. В шурфе 12012 г. они отслеживались до глубины -0,9- - 0,95 м (образцы 7, 8). Ниже располагался желтый материковый суглинок.

Палинологические определения 2012 г. по нижним пробам образцов $6,7,8$ позволили говорить, что местность вокруг поселения была открытой. Единично встречаются мелкие угольки. Пыльца семейства маревых (Chenopodiaceae), подсемейства астровых (Asteroideae), рода полыней (Artemisia) иногда присутствует в виде больших скоплений, что может свидетельствовать о близком произрастании этих растений. В общем составе преобладает пыльца травянистых и кустарничковых растений (81-91\%), на втором месте древесные породы (7-15\%), на споры приходится от 2 до $4 \%$.

Среди древесных пород больше всего пыльцы сосны (Pinus) (77-89\%), помимо этого отмечена пыльца березы (Betula), ольхи (Alnus) (по 3-9\%) и широколиственных пород (около 6\%), представленных пыльцой дуба (Quercus) и липы (Tilia).

По-видимому, большинство пыльцевых зерен имеют дальний ветровой занос. Пыльца сосны очень тонкая, иногда с почти неразвитыми мешками. Сохранность пыльцы широколиственных пород тоже имеет свои особенности, пыльца часто тонкая и иногда минерализованная.

Травянистые растения представлены прежде всего пыльцой разнотравья (37-38\%), в составе которого преимущественно отмечена пыльца подсемейств астровых (Asteroideae) (8-13\%) и цикориевых (Cichorioideae) (16-20\%), семейства бобовых (Fabaceae) (4-7\%), в небольших количествах и единично пыльца растений семейств гречишных (Polygonaceae) (горец (Polygonum), гречиха (Fagopirum)), гвоздичных (Caryophyllaceae), ворсянковых (Dipsacaceae), мальвовых (Malvaceae), гераниевых (Geraniaceae), зонтичных (Apiaceae), рода портулак (Portulaca). Также в спектре много пыльцы маревых (Chenopodiaceae) (25-36\%), в том числе солянки (Salsola). О солянках необходимо сказать несколько слов: по-видимому, этот род в спектре представлен довольно разнообразно, судя по всему, присутствуют как однолетние, так и многолетние формы.

Пыльца злаков (Роасеае) встречена в количестве около 19\%, полыней (Artemisia) от 9 до 19\%. Споровых растений в комплексе не много, встречены споры зеленых 
мхов (Bryales) (55-69\%) и папоротников семейства многоножковых (Polypodiaceae) (31-45\%).

Характер палинологических спектров свидетельствует о существовании открытых безлесных ландшафтов. Исходя из особенностей состава спектра, можно сказать, что в окрестностях памятника в это время произрастали сообщества лугово-степной и отчасти полупустынной растительности. В спектре много пыльцы разнообразного разнотравья, много представителей семейства маревых (Chenopodiaceae), в том числе и различных солянок (Salsola). Скорее всего, полупустынный тип растительности встречался на участках ближе к приморской полосе с почвогрунтами с сильным засолением из-за близко залегающих минерализованных грунтовых вод. На большей части полуострова господствовал полынно-луговой степной растительный покров. В понижениях рельефа могли селиться лугово-солончаковые сообщества.

Анализ более верхних образцов 2-5 (глубины -0,6 - -0,8 м, культурный слой) показал, что при сохранении общих черт полыннолуговой степной растительности климат колебался. Данный спорово-пыльцевой комплекс отвечает несколько иным условиям внешней среды по сравнению с предыдущим этапом. Здесь произошло увеличение роли галофильной (связанной с засолением) растительности, в основном сформированной различными видами из семейства маревых (Chenopodiaceae). Таким образом, увеличилось значение полупустынной растительности, тогда как степная растительность сохранялась на разрозненных участках, как правило, в местах с более высоким рельефом. По составу разнотравья луга-степи, скорее всего, имели целую гамму переходов от более влаголюбивых к более ксерофитным группировкам. Все эти особенности состава растительных сообществ свидетельствуют о развитии более сухих климатических условий в районе изучаемого поселения, по сравнению с предыдущим этапом. Из этого можно сделать вывод, что культурный слой, с которым связан этот палинологический комплекс, формировался в условиях полупустыни, где лугово-степные сообщества сохранились в виде отдельных участков.

Самъй верхний образеи 1 получен с глубинъ -0,55 - -0,6 м. От предыдущего комплекса отделен перерывом. В общем составе по сравнению с предыдущим комплексом становится немного больше пыльцы древесных пород (11\%) и спор (около 7\%), содержание пыльцы травянистых растений по-прежнему на первом месте и составляет $82 \%$.

Среди древесных пород все так же доминирует пыльца сосны (Pinus) (83\%), процент содержания пыльцы широколиственных пород немного сокращается до 7\% (они представлены пыльцой дуба (Quercus) и грецкого ореха (Yuglans)). Впервые в разрезе встречена пыльца ивы (Salix) (около $5 \%$ ). Также отмечена пыльца березы (Betula), ольхи (Alnus).

В группе травянистых растений больше всего пыльцы маревых (Chenopodiaceae) $(41 \%)$, в том числе и солянки (Salsola). Cодержание пыльцы злаков (Роасеае) составляет $22 \%$, а на пыльцу разнотравья приходится 29\%. По сравнению с предыдущими комплексами состав разнотравья становится беднее. Количество пыльцы полыней (Artemisia) составляет 9\%. Впервые в разрезе единично отмечена пыльца эфедры (Ephedra).

Подобный состав спектров также характеризует открытые ландшафты, но соотношение между лугово-степными и полупустынными группировками изменилось. Стало заметно меньше полынников, которые являются одним из показателей опустыненных сообществ. Увеличилась роль злаков, среди которых отмечены культурные формы. Это указывает на изменение палеогеографических условий на данном этапе по сравнению с предыдущим. Можно предположить, что галофильная растительность в основном сохранилась только вблизи побережий, тогда как роль лугово-степных формаций увеличилась, вероятно, появились участки пашен. Как датируется образец 1 , сказать трудно. Он может относиться к времени после существования обитателей майкопского поселка Тузла-15. 
2014 г. Раскоп 5 (кв. 12014 г)

\begin{tabular}{|c|c|c|c|}
\hline Глубины & $\begin{array}{c}\text { Краткая характеристика } \\
\text { состава пыльцы }\end{array}$ & Слой & $\begin{array}{c}\text { Споро-пыльцевой } \\
\text { комплекс }\end{array}$ \\
\hline $\begin{array}{l}-0,5--0,8 \text { м } \\
7,8 \text { образцы }\end{array}$ & $\begin{array}{l}\text { Высокое содержание маревых, } \\
\text { возрастает процент пыльцы } \\
\text { цикоревых, астровых, появляется } \\
\text { пыльца широколиственных (дуб, } \\
\text { сосна, липа) }\end{array}$ & $\begin{array}{l}\text { Надкарбонатный } \\
\text { культурный слой }\end{array}$ & СПК-III \\
\hline $\begin{array}{l}-1,3--0,8 \text { м } \\
3-6 \text { образцы }\end{array}$ & $\begin{array}{l}\text { Много маревых, менее } \\
\text { полыней, доминант ландшафтов } \\
\text { полупустыней. Древесных пород } \\
\text { нет }\end{array}$ & $\begin{array}{l}\text { Карбонатный } \\
\text { горизонт и переход } \\
\text { к надкарбонатному } \\
\text { горизонту }\end{array}$ & СПК-ІІб \\
\hline $\begin{array}{l}-1,2--1,3 \text { м } \\
2 \text { образец }\end{array}$ & $\begin{array}{l}\text { Разнотравные степи, полупустыни, } \\
\text { много маревых и полыней, мало } \\
\text { широколиственных пород }\end{array}$ & $\begin{array}{l}\text { Карбонатный } \\
\text { горизонт }\end{array}$ & СПК-1 \\
\hline $\begin{array}{l}-1,32--1,3 \text { м } \\
1 \text { образец }\end{array}$ & $\begin{array}{l}\text { Разнотравные степи, полупустыни, } \\
\text { много маревых и полыней, мало } \\
\text { широколиственных пород }\end{array}$ & $\begin{array}{l}\text { карбонатный } \\
\text { горизонт }\end{array}$ & СПК-1 \\
\hline
\end{tabular}

Отбор проб 2014 г. стал более показательным. В квадрате 12014 г. они отбирались из участка, расположенного рядом с жилищем 4. Диапазон анализов был шире. Наиболее древние образцы были взяты с глубин -1,32 - -1,33 м. В кратком изложении результаты палинологического анализа таковы. В общем составе преобладает пыльца травянистых и кустарничковых растений 86-88\%, тогда как пыльца древесных пород и споры в сумме дают только 11-15\%. Среди малого количества пыльцы древесных пород преобладает пыльца сосны, встречается пыльца березы, а также широколиственных пород, таких как дуб и лещина. В группе пыльцы травянистых и кустарничковых растений преобладают разнообразные маревые, много пыльцы растений семейства сложноцветных (цикориевые (Cichorioideae) и астровые (Asteroideae). Постоянно присутствует пыльца полыней (Artemisia), бобовых (Fabaceae) и крестоцветных (Brassicaceae). Среди споровых растений встречены только споры папоротников семейства многоножковых Polypodiaceae и зеленых мхов (Bryales).

Исходя из характера спектров, можно утверждать, что в этот интервал времени в окрестностях памятника произрастали разнотравные степи, в наиболее неблагоприятных участках рельефа чаще селились полупустынные растительные сообщества. Климат был жаркий, позволяющий откладываться карбонатам. Следов майкопского населения не фиксируется. Археологические определения эти глубины связывают с «материком».

На глубинах перехода от надкарбонатного слоя к карбонатному слою -0,8 - -1,2 м отмечается СПК-ІІ. Он выделен по образцам 3-6 (с интервала глубин от -1,2 до -0,8 м). Сохранность пыльцы и спор плохая, много минерализованных зерен, для части пыльцевых зерен трудно или невозможно определить систематическую принадлежность.

Для комплекса характерно высокое содержание пыльцы растений семейства маревых (Chenopodiaceae) наряду с меньшим количеством пыльцы полыней (Artemisia) и злаков (Роасеае). Состав пыльцы разнотравья включает относительно небольшое количество родов и семейств. Характер споровых растений близок к предыдущему комплексу.

В период формирования этого комплекса преобладала полупустынная растительность, доминировали растительные сообщества с господством растений семейства 
2014 г. Квадрат 2, северная окраина поселка

\begin{tabular}{|c|c|c|c|}
\hline Глубины & $\begin{array}{c}\text { Краткая характеристика } \\
\text { состава пыльцы }\end{array}$ & Слой & $\begin{array}{c}\text { Споро-пыльцевой } \\
\text { комплекс }\end{array}$ \\
\hline 8 образец & $\begin{array}{l}\text { Резко возрастает процент пыльцы } \\
\text { маревых. Климат становится более } \\
\text { сухим. Идет засоление грунтов. } \\
\text { Уменьшилась продуктивность } \\
\text { разнотравья. Местность стала } \\
\text { полупустынной, со значительными } \\
\text { периодами засухи }\end{array}$ & & СПК-IV \\
\hline $\begin{array}{l}-0,95--0,66 \text { м } \\
5-7 \text { образцы }\end{array}$ & $\begin{array}{l}\text { Преобладает пыльца травянистых } \\
\text { и кустарничковых. Становится } \\
\text { меньше пыльцы злаковых, } \\
\text { больше пыльцы маревых и } \\
\text { увеличивается количество пыльцы } \\
\text { широколиственных (дуба). Климат } \\
\text { становится более теплым, что } \\
\text { способствует засолению почв. } \\
\text { Господствуют луговые и степные } \\
\text { ландшафты, могут появляться } \\
\text { островки леса }\end{array}$ & надкарбонатный слой & СПК-III \\
\hline $\begin{array}{l}-0,99--1,05 \\
3,4 \text { образцы }\end{array}$ & $\begin{array}{l}\text { много маревых, но увеличивается } \\
\text { количество пыльцы злаков, } \\
\text { присутствуют мхи. Условия более } \\
\text { гумидные }\end{array}$ & $\begin{array}{l}\text { карбонатный } \\
\text { горизонт и переход } \\
\text { к надкарбонатному } \\
\text { горизонту }\end{array}$ & СПК-IIa \\
\hline $\begin{array}{l}-1,3--1,0 \\
1,2 \text { образцы }\end{array}$ & $\begin{array}{l}\text { господство степных сообществ, } \\
\text { засоление почв с преобладанием } \\
\text { маревых, мало широколиственных } \\
\text { пород }\end{array}$ & $\begin{array}{l}\text { карбонатный } \\
\text { горизонт }\end{array}$ & СПК-1 \\
\hline
\end{tabular}

маревых (Chenopodiaceae). Лугово-степные группировки с ограниченным преобладанием злаков сохранялись на более низких влажных участках территории. Климат был сухой и с длительными периодами засухи. Образцы проб с глубин -1,2 - -0,8 м еще не связаны с массовыми находками керамики.

Выше, на уровне надкарбонатного слоя на глубинах -0,8 - -0,5 м образцы отражают очередные климатические изменения. Они связаны с СПК-III и характеризуют климат времени существования культурного слоя поселения. Находки на глубинах $-0,8$ м совпадают с верхним уровнем ямы жилища 4. Сохранность пыльцы и спор плохая, единично встречаются мелкие угольки.

В общем составе по-прежнему преобладает пыльца травянистых и кустарничковых растений, тогда как пыльца древесных пород составляет около 2\%. Среди пыльцы древесных пород присутствуют единичные зерна сосны, дуба и липы, тогда как в предыдущем комплексе, при общей большей роли древесных пород пыльца широколиственных пород отсутствует.

Пыльцевые зерна и споры часто очень плохой сохранности и/или разорваны, возможно, часть пыльцы и спор находятся во вторичном залегании. Среди травянистых и кустарничковых растений наряду с высоким содержанием пыльцы растений семейства маревых (Chenopodiaceae) возрастает участие пыльцы растений семейства сложноцветных (Compositae) (цикориевые (Cichorioideae) и астровые (Asteroideae)). Состав споровых близок к предыдущим комплексам.

Таким образом, можно сделать вывод, что в период образования изученных отло- 


\section{Результаты спорово-пыльцевого анализа. Разрез на поселении Тузла-15}

\begin{tabular}{|c|c|c|c|c|}
\hline Систематический список & $\begin{array}{c}1 \\
0,57 \text { м } \\
\text { зерна/проц }\end{array}$ & $\begin{array}{c}2 \\
0,64 \text { м } \\
\text { зерна/проц }\end{array}$ & $\begin{array}{c}3 \\
0,67 \text { м } \\
\text { зерна/проц }\end{array}$ & $\begin{array}{c}4 \\
0,72 \text { м } \\
\text { зерна/проц }\end{array}$ \\
\hline \multicolumn{5}{|c|}{ ОБЩИЙ СОСТАВ } \\
\hline $\begin{array}{l}\text { Деревья } \\
\text { Травы } \\
\text { Споры }\end{array}$ & $\begin{array}{c}42 / 11,1 \\
309 / 81,5 \\
28 / 7,4\end{array}$ & $\begin{array}{c}37 / 8,4 \\
387 / 87,8 \\
17 / 3,9 \\
\end{array}$ & $\begin{array}{c}29 / 6,4 \\
404 / 89 \\
21 / 4,6\end{array}$ & $\begin{array}{c}33 / 7 \\
426 / 90,4 \\
12 / 2,5\end{array}$ \\
\hline \multicolumn{5}{|c|}{ Деревья } \\
\hline $\begin{array}{l}\text { Деревья основные } \\
\text { Pinus sylvestris } \\
\text { Alnus } \\
\text { Betula sec.Albae } \\
\text { Salix }\end{array}$ & $\begin{array}{c}39 / 92,9 \\
35 / 83,3 \\
1 / 2,4 \\
1 / 2,4 \\
2 / 4,8\end{array}$ & $\begin{array}{c}32 / 86,5 \\
31 / 83,8 \\
- \\
1 / 2,7 \\
-\end{array}$ & $\begin{array}{c}25 / 86,2 \\
24 / 82,8 \\
- \\
1 / 3,4 \\
-\end{array}$ & $\begin{array}{c}30 / 90,9 \\
26 / 78,8 \\
3 / 9,1 \\
1 / 3 \\
-\end{array}$ \\
\hline $\begin{array}{l}\text { Деревья широколиственные } \\
\text { Guercus } \\
\text { Tilia } \\
\text { Yuglans } \\
\end{array}$ & $\begin{array}{l}3 / 7,1 \\
2 / 4,8 \\
- \\
1 / 2,4 \\
\end{array}$ & $\begin{array}{c}5 / 13,5 \\
4 / 10,8 \\
1 / 2,7 \\
- \\
\end{array}$ & $\begin{array}{l}4 / 13,8 \\
3 / 10,3 \\
- \\
1 / 3,4 \\
\end{array}$ & $\begin{array}{c}3 / 9,1 \\
2 / 6,1 \\
1 / 3 \\
- \\
\end{array}$ \\
\hline \multicolumn{5}{|c|}{ Травы } \\
\hline $\begin{array}{l}\text { Tравы основные } \\
\text { Ephedra } \\
\text { Poaceae } \\
\text { Chenopodiaceae } \\
\text { Artemisia }\end{array}$ & $\begin{array}{c}219 / 70,9 \\
1 / 0,3 \\
67 / 21,7 \\
123 / 39,8 \\
28 / 9,1\end{array}$ & $\begin{array}{c}259 / 66,9 \\
- \\
72 / 18,6 \\
150 / 38,8 \\
37 / 9,6\end{array}$ & $\begin{array}{c}264 / 65,3 \\
- \\
64 / 15,8 \\
147 / 36,4 \\
53 / 13,1\end{array}$ & $\begin{array}{c}334 / 78,4 \\
- \\
93 / 21,8 \\
143 / 33,6 \\
98 / 23\end{array}$ \\
\hline $\begin{array}{l}\text { Разнотравье } \\
\text { Fagopyrum } \\
\text { Polygonum } \\
\text { Polygonum persicaria } \\
\text { Brassicaceae } \\
\text { Ranunculaceae } \\
\text { Lamiaceae } \\
\text { Caryophyllaceae } \\
\text { Fabaceae } \\
\text { Dipsacaceae } \\
\text { Malvaceae } \\
\text { Geraniaceae } \\
\text { Apiaceae } \\
\text { Cichorioideae } \\
\text { Asteroideae } \\
\text { Portulaca } \\
\text { Salsola } \\
\end{array}$ & $\begin{array}{c}90 / 29,1 \\
- \\
- \\
- \\
1 / 0,3 \\
- \\
- \\
- \\
16 / 5,2 \\
1 / 0,3 \\
- \\
- \\
- \\
41 / 13,3 \\
28 / 9,1 \\
- \\
3 / 1 \\
\end{array}$ & $\begin{array}{c}128 / 33,1 \\
- \\
1 / 0,3 \\
1 / 0,3 \\
- \\
5 / 1,3 \\
- \\
- \\
22 / 5,7 \\
6 / 1,6 \\
- \\
2 / 0,5 \\
- \\
43 / 11,1 \\
36 / 9,3 \\
2 / 0,5 \\
10 / 2,6 \\
\end{array}$ & $\begin{array}{c}140 / 34,7 \\
- \\
2 / 0,5 \\
1 / 0,2 \\
- \\
1 / 0,2 \\
- \\
- \\
21 / 5,2 \\
2 / 0,5 \\
- \\
- \\
- \\
68 / 16,8 \\
39 / 9,7 \\
- \\
6 / 1,5 \\
\end{array}$ & $\begin{array}{c}92 / 21,6 \\
- \\
2 / 0,5 \\
- \\
1 / 0,2 \\
1 / 0,2 \\
1 / 0,2 \\
- \\
14 / 3,3 \\
1 / 0,2 \\
- \\
1 / 0,2 \\
- \\
41 / 9,6 \\
25 / 5,9 \\
- \\
5 / 1,2 \\
\end{array}$ \\
\hline \multicolumn{5}{|c|}{ Cnоры } \\
\hline $\begin{array}{l}\text { Bryales } \\
\text { Sphagnum } \\
\text { Equisetum } \\
\text { Polypodiaceae }\end{array}$ & $\begin{array}{l}17 / 60,7 \\
1 / 3,6 \\
1 / 3,6 \\
9 / 32,1\end{array}$ & $\begin{array}{c}9 / 52,9 \\
- \\
1 / 5,9 \\
7 / 41,2\end{array}$ & $\begin{array}{c}12 / 57,1 \\
- \\
- \\
9 / 42,9\end{array}$ & $\begin{array}{l}8 / 66,7 \\
- \\
- \\
4 / 33,3\end{array}$ \\
\hline
\end{tabular}

жений состав растительного покрова неод- нократно менялся. Первый этап и второй 
этап (СПК-1, II) соответствовал более мезофильным условиям среды, когда увеличивалась роль степных сообществ со значительной гаммой переходов от более влажных к более сухим типам растительных группировок. О некоторой увлажненности климата времени СПК-III может также свидетельствовать незначительное присутствие в спектрах пыльцы широколиственных пород (дуб, липа) и небольшое участие пыльцы березы наряду с сосной. Дата жилища 4 Ki-19217 $4170 \pm 30$ BP 2876-2676 BC.

Квадрат 22014 г. располагался к северу от квадрата 12014 г. Находок керамики в нем практически не было. Данные палинологического отбора проб таковы.

I спорово-пьльиевой комплекс (разнотравъе, маревые, злаки) выделен по образцам 1 и 2 из материкового суглинка (слои 1 и 2. Глубины -1,3--1 м). Сохранность пыльцы и спор различная, встречаются минерализованные зерна. Доминирующее положение занимает пыльца травянистых и кустарничковых растений, на долю которых приходится 84-88\%. Пыльцы древесных пород и спор значительно меньше, их количество составляет $9-10 \%$ и 3-6\% соответственно.

Среди древесных пород в основном отмечена пыльца сосны (Pinus) и в образце 1 единично пыльцевые зерна ольхи (Ainas), березы (Betula) и дуба (Quercus). В группе травянистых и кустарничковых растений преобладает пыльца разнотравья, в составе которого много различных форм пыльцы растений семейства сложноцветных (Compositae) (цикориевые (Cichorioideae) и астровые (Asteroideae). В небольших количествах и единично присутствует пыльца семейств гераниевых (Geraniaceae), зонтичных (Apiaceae), бобовых (Fabaceae). Пыльца полыней (Artemisia) составляет 4-9\%. В образце 2 единично встречена пыльца эфедры (Ephedra). Споровые растения представлены спорами зеленых мхов (Bryales) и папоротников семейства многоножковых (Polypodiaceae).

Этот комплекс отражает открытый природный ландшафт с господством степных сообществ, где также существовали участки засоленных почв с преобладанием различ- ных группировок, образованных растениями семейства маревых (Chenopodiaceae).

II спорово-пьльщевой комплекс (разнотравъе, злаки, единично широколиственные породы) выделен по образцам 3 и 4 отобранных в интервале 0,99-1,05 м в коричневатом суглинке. Состав спектров комплекса во многом повторяет предыдущий комплекс. Основное отличие связано с более высоким содержанием пыльцы злаков (Роасеае) и гераниевых (Geraniaceae) (в разнотравье). Важно также отметить присутствие спор сфагновых мхов (Sphagnum) в группе споровых растений.

III спорово-пьльчевой комплекс (разнотравъе, маревые, с участием широколиственных пород) выделен по образцам 5-7 отобранных в интервале 0,66-0,95 м из предкарбонатного палевого слоя. В общем составе по-прежнему преобладает пыльца травянистых и кустарничковых растений. В группе древесных пород становится больше пыльцы дуба (Quercus), ольхи (Alnus) и березы (Betula). Состав травянистых и кустарничковых растений также меняется по сравнению с предыдущим комплексом, становится меньше пыльцы злаков (Роасеае) и несколько увеличивается содержание пыльцы растений семейства маревых (Chenopodiaceae). Климат стал более теплым, что могло способствовать засолению почв на отдельных участках. Возможно, это повлияло на увеличение роли маревых в спектре. Наиболее широко были распространены лугово-степные группировки и возможно появление небольших слабо лесистых участков.

IV споро-пыльиевой комплекс (маревые, разнотравъе, злаки) выделен по образцу 8 из комковатого коричневого суглинка на границе со слоем распашки (с глубины -0,62 м). В образце встречаются единичные угольки, сохранность спор и пыльцы лучшая, чем во всех других образцах из этого разреза. Характер спектров комплекса резко отличается от предыдущих. Как и в других комплексах здесь в общем составе преобладает пыльца травянистых и кустарничковых растений, но меняется соотношение между содержанием пыльцы растений семейства маревых (Chenopodiaceae) и других растений из этой группы. Представители семейства 
Таблича 12 (продолжение 1)

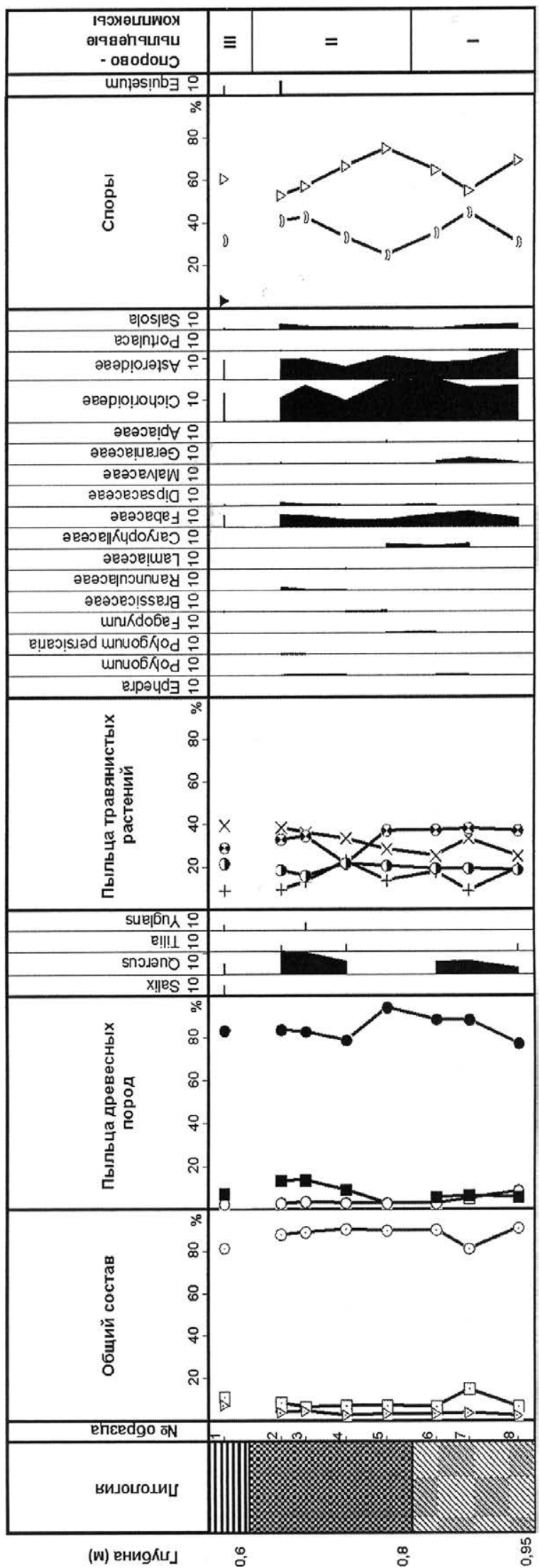


Таблича 12 (продолжение 2)

\begin{tabular}{|c|c|c|c|c|}
\hline Систематический список & $\begin{array}{c}5 \\
0,77 \text { м } \\
\text { зерна/проц }\end{array}$ & $\begin{array}{c}6 \\
0,83 \text { м } \\
\text { зерна/проц }\end{array}$ & $\begin{array}{c}7 \\
0,87 \text { м } \\
\text { зерна/проц }\end{array}$ & $\begin{array}{c}8 \\
0,93 \text { м } \\
\text { зерна/проц }\end{array}$ \\
\hline \multicolumn{5}{|c|}{ ОБЩИЙ СОСТАВ } \\
\hline $\begin{array}{l}\text { Деревья } \\
\text { Травы } \\
\text { Споры }\end{array}$ & $\begin{array}{c}35 / 7,1 \\
443 / 89,7 \\
16 / 3,2\end{array}$ & $\begin{array}{c}35 / 6,7 \\
472 / 90,1 \\
17 / 3,2\end{array}$ & $\begin{array}{c}78 / 14,9 \\
424 / 81,2 \\
20 / 3,8\end{array}$ & $\begin{array}{l}35 / 6,6 \\
485 / 91 \\
13 / 2,4\end{array}$ \\
\hline \multicolumn{5}{|c|}{ Деревья } \\
\hline $\begin{array}{l}\text { Деревья основные } \\
\text { Pinus sylvestris } \\
\text { Alnus } \\
\text { Betula sec.Albae } \\
\text { Salix }\end{array}$ & $\begin{array}{c}35 / 100 \\
33 / 94,3 \\
1 / 2,9 \\
1 / 2,9 \\
-\end{array}$ & $\begin{array}{c}33 / 94,3 \\
31 / 88,6 \\
1 / 2,9 \\
1 / 2,9 \\
-\end{array}$ & $\begin{array}{c}73 / 93,6 \\
69 / 88,5 \\
4 / 5,1 \\
- \\
-\end{array}$ & $\begin{array}{c}33 / 94,3 \\
27 / 77,1 \\
3 / 8,6 \\
3 / 8,6 \\
-\end{array}$ \\
\hline $\begin{array}{l}\text { Деревья широколиственные } \\
\text { Quercus } \\
\text { Tilia } \\
\text { Yuglans }\end{array}$ & $\begin{array}{l}- \\
- \\
- \\
-\end{array}$ & $\begin{array}{l}2 / 5,7 \\
2 / 5,7 \\
- \\
-\end{array}$ & $\begin{array}{l}5 / 6,4 \\
5 / 6,4 \\
- \\
-\end{array}$ & $\begin{array}{l}2 / 5,7 \\
1 / 2,9 \\
1 / 2,9 \\
-\end{array}$ \\
\hline \multicolumn{5}{|c|}{ Травъь } \\
\hline $\begin{array}{l}\text { Tравы основные } \\
\text { Ephedra } \\
\text { Poaceae } \\
\text { Chenopodiaceae } \\
\text { Artemisia } \\
\end{array}$ & $\begin{array}{c}278 / 62,8 \\
- \\
91 / 20,5 \\
126 / 28,4 \\
61 / 13,8 \\
\end{array}$ & $\begin{array}{c}295 / 62,5 \\
- \\
91 / 19,3 \\
120 / 25,4 \\
84 / 17,8 \\
\end{array}$ & $\begin{array}{c}262 / 61,8 \\
- \\
82 / 19,3 \\
142 / 33,5 \\
38 / 9 \\
\end{array}$ & $\begin{array}{c}305 / 62,9 \\
- \\
90 / 18,6 \\
122 / 25,2 \\
93 / 19,2 \\
\end{array}$ \\
\hline $\begin{array}{l}\text { Разнотравье } \\
\text { Fagopyrum } \\
\text { Polygonum } \\
\text { Polygonum persicaria } \\
\text { Brassicaceae } \\
\text { Ranunculaceae } \\
\text { Lamiaceae } \\
\text { Caryophyllaceae } \\
\text { Fabaceae } \\
\text { Dipsacaceae } \\
\text { Malvaceae } \\
\text { Geraniaceae } \\
\text { Apiaceae } \\
\text { Cichorioideae } \\
\text { Asteroideae } \\
\text { Portulaca } \\
\text { Salsola }\end{array}$ & $\begin{array}{c}165 / 37,2 \\
1 / 0,2 \\
- \\
- \\
2 / 0,5 \\
- \\
- \\
8 / 1,8 \\
15 / 3,4 \\
1 / 0,2 \\
- \\
- \\
2 / 0,5 \\
83 / 18,7 \\
48 / 10,8 \\
- \\
5 / 1,1\end{array}$ & $\begin{array}{c}177 / 37,5 \\
2 / 0,4 \\
2 / 0,4 \\
1 / 0,2 \\
- \\
- \\
- \\
3 / 0,6 \\
28 / 5,9 \\
2 / 0,4 \\
2 / 0,4 \\
5 / 1,1 \\
- \\
93 / 19,7 \\
37 / 7,8 \\
- \\
2 / 0,4\end{array}$ & $\begin{array}{c}162 / 38,2 \\
- \\
2 / 0,5 \\
- \\
- \\
- \\
- \\
8 / 1,9 \\
30 / 7,1 \\
- \\
- \\
11 / 2,6 \\
- \\
67 / 15,8 \\
36 / 8,5 \\
1 / 0,2 \\
7 / 1,7\end{array}$ & $\begin{array}{c}180 / 37,1 \\
- \\
- \\
- \\
- \\
- \\
- \\
- \\
18 / 3,7 \\
1 / 0,2 \\
- \\
2 / 0,4 \\
1 / 0,2 \\
80 / 16,5 \\
65 / 13,4 \\
1 / 0,2 \\
12 / 2,5\end{array}$ \\
\hline \multicolumn{5}{|c|}{ Cnоры } \\
\hline $\begin{array}{l}\text { Bryales } \\
\text { Sphagnum } \\
\text { Equisetum } \\
\text { Polypodiaceae }\end{array}$ & $\begin{array}{l}12 / 75 \\
- \\
- \\
4 / 25\end{array}$ & $\begin{array}{c}11 / 64,7 \\
- \\
- \\
6 / 35,3\end{array}$ & $\begin{array}{l}11 / 55 \\
- \\
- \\
9 / 45\end{array}$ & $\begin{array}{l}9 / 69,2 \\
\quad- \\
- \\
4 / 30,8\end{array}$ \\
\hline
\end{tabular}


маревых начинают заметно преобладать (49\%), что может говорить о более сухом климате и, как следствие, засолении грунтов. Среди древесных пород присутствует только пыльца сосны (Pinus). В состав травянистых и кустарничковых растений помимо пыльцы растений семейства маревых (Chenopodiaceae) входит пыльца злаков (Poасеае) (14\%), полыней (Artemisia) (12\%), цикориевых (Cichorioideae) (около 7\%), астровых (Asteroideae) (16\%), единично крестоцветных (Brassicaceae) и бобовых (Fabaceae). Из споровых растений отмечены споры зеленых мхов (Bryales) и папоротников семейства многоножковых Polypodiaceae.

По сравнению с предыдущим комплексом состав и структура растительных со- обществ существенно изменилась. Климат стал значительно суше. Уменьшилась видовая насыщенность и продуктивность травостоя. Судя по составу спектра, это была полупустыня со значительными периодами засухи, в которой преобладали солянковые полукустарничковые сообщества. В это время майкопское население покидает поселок.

Данные палинологического анализа хорошо согласуются с результатами фитолитного анализа, описанными выше. Так, фитолитов нет ниже культурного слоя в зоне карбонатных отложений, так же как их нет и выше отложений культурного слоя соответственно на уровне отбора IV палинологического комплекса. 


\section{ЗАКЛЮЧЕНИЕ}

Обобщающие выводы по анализу материалов поселения Тузла-15 мы скомпоновали в виде нескольких блоков, которые приводим ниже.

Первый блок. Раскопки на поселении Тузла-15 показали особенность культурного слоя памятника. Толщина его достигает 50-60 см. Культурный слой начинается от уровня залегания карбонатов, и его верх нарушен распашкой. Слой распашки имеет толщину 40-60 см. Такая же ситуация выявлена на поселении Чекон (Бочковой, 2013; Кореневский, Юдин, 2019). Культурный слой на пос. Чекон, по наблюдениям 2018 г., залегал от поверхности земли на глубину около 1 м. Его подстилал слой карбонатов. Слой погребенного дерна практически не был виден. Фрагменты керамики располагались на разных уровнях, означая как бы два главных «горизонта». Первый уровень (горизонт) был близок к слою карбонатов. Второй уровень (горизонт) был приближен к верхнему окончанию культурного слоя (раскопки 2018 г.) (Кореневский, Юдин, 2019).

Такие данные позволяют прийти к заключению, что культурный слой майкопского поселения мог накапливаться очень долгое время. В нем возможно наблюдать отдельные бытовые комплексы (развалы черепков, выкладки из турлука и камней) на разных глубинах и, соответственно, различной древности. Однако развалы майкопской керамики и артефактов не оставили локальных прослоек «горизонтов». Их находки были сосредоточены в хозяйственных ямах и заброшенных постройках-полуземлянках. Датировка комплексов могла бы указывать на время впуска объекта в культурный слой данного объекта. Но в толще культурного слоя она, как правило, не определяется. Отсюда мог возникнуть большой разброс в диапазонах радиокарбонных дат. Так например, на поселении Чекон даты имеют значение позднего диапазона дат МНО
34-30 вв. до н. э. (3311- 2918 ВС) и среднего диапазона 37-34 вв. до н. э. (3660-3313 ВС) (Гей, Зазовская, 2013. С. 81-84).

Дата постройки раскопок 2013 г. на поселении Тузла-15 в целом соответствует диапазону 34-30 вв. до н. э. (Кореневский, 2014, 2016). Дата постройки раскопок 2015 г. 29-28 вв. до н.э. (Кi-192174170 \pm 30 2876-2676 ВС). Признаки ее впуска в культурный слой были пойманы выше горизонта карбонатов. Такая поздняя дата для комплекса майкопско-новосвободненской общности позволяет ставить вопрос о ее финале в Причерноморской зоне в начале III тыс. до н. э.

Как на фоне изложенной выше информации сейчас может быть рассмотрена стратиграфия поселения Галюгаевское 1? Сопоставляя все данные о стратиграфии находок на этом поселении, можно сказать, что на нем есть находки, непосредственно лежащие в слое карбонатов, и находки, обнаруженные существенно выше карбонатного слоя. Дата 34-32 вв. до н. э. происходила из образца кости, взятого вблизи самого позднего строения 1991 г. раскопок. Как датируется на поселении Галюгаевское 1 уровень слоя карбонатов-вопрос остался открытым. По данным стратиграфии этого поселения можно сказать, что отложение карбонатного слоя могло идти непосредственно по заполнению мусорных ям (рис. 118).

На другом поселении Галюгаевское III дата по кости животного оказалась существенно древнее в диапазоне 40-37 вв. до н. э. То есть она может указывать на более раннее время появления носителей МНО в данном месте, и основавших иной памятник, не поселение Галюгаевское 1.

Таким образом, сейчас можно считать, что существование носителей культуры МНО и ее раннего варианта в Предкавказье было долгим. Оно растянулось по времени с диапазона 40/37 вв. до н.э. 
до 34-30 вв. до н.э. и в некоторых местах до начала III тыс. до н. э.

Утверждение, что тонкие слои майкопских поселений означают кратковременность существования майкопской культуры неправомерно (Ръсин, 2012. С. 215).

Второй блок. По данным палинологического и фитолитного анализов появление майкопских племен в районе поселения Тузла-15 происходило в условиях смены засушливого климата степей более гумидными условиями, приводящими к формированию карбонатных отложений в толще каштановых почв. Следы такого же явления ранее были зафиксированы на поселении Галюгаевское 1 и Чекон (Кореневский, 2018. C. 89-91), а также на ряде других объектов времени майкопской культуры, возникших на каштановых почвах. Эти данные позволяют полгать, что миграции племен майкопско-новосвободненской общности имели прежде всего экономические причины, связанные с изменением климата. Такие перемены могли иметь очень широкие последствия в миграционных перемещениях носителей древних культур и обусловить стадиальные явления возникновения и исчезновения историо-культурных феноменов (Кореневский, 2005).

Третий блок. Материалы поселения Тузла-15 возможно использовать для характеристики хозяйственно-культурного типа местных племен псекупского варианта. Прежде всего, можно говорить, что локализация памятника типична для большинства носителей культуры МНО. Она связано с обитанием у водного источника в долине реки. В данном случае-вблизи морского побережья. Культурный слой мощностью около полуметра свидетельствует об оседлости. Однако такая оседлость могла носить характер временного проживания, ухода и возвращения на обжитое место. Показателем такого способа жизни на памятнике является слабая насыщенность культурного слоя в междужилищном пространстве.

В заполнении помещений-полуземлянок найдено много костей животных, связанных со следами пиршества. В коллекции доминируют кости овцы, затем кости к.р.с.
Устойчиво представлены кости свиньи. Есть кости птицы, кости рыб и целые собрания створок устриц. Единичными являются находки костей лошади. По всей вероятности, обнаруженные остеологические остатки являлись отходами крупных трапез, которыми сопровождался ритуальный заброс оставляемой постройки.

Прямой информации об использовании растительной пищи и продуктов земледелия не зафиксировано в силу специфики таких источников. Однако о широком употреблении растительной пищи в виде различных каш могут свидетельствовать многочисленные находки мисок, изготовленных по технологиям высокого класса, или мисок, изготовленных из формовочных масс с искусственными минеральными примесями. Миски высокого класса украшались крашеными полосами орнамента, повышающего престиж используемой посуды.

О земледелии носителей майкопского и псекупского вариантов могли свидетельствовать бронзовые мотыги и многочисленные зернотерки, вкладыши серпов, находимые на поселениях. Что выращивали майкопцы, сказать трудно, но еще у предмайкопских племен местного халколита были известны сорта пшеницы и ячменя (Осташинский и др., 2016). В использовании растительной пищи большое значение мог иметь тростник, росший в изобилии по берегам рек. О важном пищевом ресурсе в глубокой древности на основе тростника хорошо свидетельствует эпос ингушей и практика питания в условиях выживания при ограниченных ресурсах хлебных злаков (Цароева, 2014. С. 78; Павлов, 1942).

Мотыжное земледелие быстро приводило к истощению плодородности почвы и толкало к перемене мест обитания в поисках более плодородного участка, как полагает крупный специалист по аграрной культуре племен бронзового века Я. Киквидзе (Киквидзе, 1987). В отношении развития скотоводства ведущий специалист в этой области В.М. Шамиладзе писал: «Кавказ не был очагом кочевничества, ни ареной ранних кочевников» (Шамиладзе, 1982. С. 70, 76). Подлинное кочевничество, или номадизм, 
как модель скотоводческого хозяйства оформилось в основном с приручением лошади под верх.

В целом полученные данные могут подтверждать прежний тезис в определении хозяйственно-культурного типа майкопских племен, как подвижно-оседлого хозяйства скотоводов и земледельцев (Кореневский, 2004. С. 71-77). У носителей различных вариантов МНО при этом могла быть своя специфика и специализация. Майкопским племенам был свойственен стационар и подвижность. Скот мог пастись на пастбищах по долинам рек и содержаться в стойлах. Население могло заниматься охотой, собирательством и мотыжным земледелием. В причерноморской зоне особенностью местных племен могло быть использование в пищу раковин и рыб. Это был хороший дополнительный пищевой ресурс.

Четвертый блок. Увеличение источников по поселениям псекупского варианта МНО в причерноморской зоне, установление такого явления, как ритуализированная процедура забрасывания оставленных помещений, использование ям, равных по размерам жилищам-полуземлянкам для эпизодического размещения в них умерших людей, захоронение сородичей в культурном слое поселения - все эти наблюдения позволяют ставить и решать вопросы о том, что из себя представляли носители псекупского варианта в причерноморской зоне и насколько они были похожи или отличались от населения МНО более восточных областей Предкавказья.

Плтый блок. В литературе неоднократно подчеркивалась близость керамического комплекса майкопской культуры лейлатепинской культуре Южного Кавказа (Мусеибли, 2011). Это положение более всего соответствует майкопскому варианту МНО. При сопоставлении керамического комплекса поселения Тузла-15 и Чекон с керамикой лейлатепинской культуры можно фиксировать очевидное своеобразие причерноморских памятников по сравнению с лейлатепинской культурой. На них не наблюдается керамика 1 класса со знаками, встречается крашеная керамика, присутствие которой плохо документируется для лейлатепинской культуры. Трудно говорить о тождестве лепной керамики южнокавказских и причерноморских памятников. Поэтому эти отличия потребуют своего объяснения в будущем при сопоставлении рассматриваемых материалов на более широком фоне аналогий. 


\section{SUMMARY}

We put together summerazing conclusions on the analysis of Tuzla-15 settlement materials in the form of several blocks, which are given below.

The first block. Excavations at Tuzla-15 settlement showed the peculiarity of the cultural layer of the monument. Its thickness reaches $50-60 \mathrm{~cm}$. Cultural layer starts from the level of occurrence of carbonates, and its top is disturbed by plowing. The plowing layer has a thickness of 40-60 cm, the same situation is found in the settlement Checon (Bochkovoy 2013; Yudin, 2018). The cultural layer on the settlement Checon 2018 lies from the surface to a depth of about $1 \mathrm{~m}$. It spread above a layer of carbonates. The layer of buried soil was almost invisible. Fragments of ceramics were located on different levels, meaning as it were the two main "horizon". The first level (horizon) was close to the carbonate layer. The second level (horizon) was close to the upper end of the cultural layer (excavations 2018) (Korenerskiy, Yudin, 2019).

Such data lead to the conclusion that the cultural layer of the Maikop's settlement could accumulate for a very long time. It is possible to observe individual household systems (disintegrated shards, calculations of turluk and stones) at different depths and, consequently, different antiquity. However, the collapse of the Maikop pottery and artifacts have left the local layers of "horizon". Their findings were concentrated in household's pits and abandoned buildingssemi-dugouts. Dating complexes could indicate the time of admission of the object in the cultural layer of the object. But in the thickness of the cultural lay$\mathrm{er}$, it is usually not determined. Hence there could be a large variation in the range of radiocarbon dates. So for example, on the settlement date Checon have the value of a late date range 34-30 BC (33112918 BC) and mid-range 37-34 BC (3660-3313 BC) (Gey, Zazouskaya, 2013. S. 81-84).

Date of construction excavations of 2013 in the settlement Tuzla-15 in general corresponds to the range of 34-30 BC (Koreneuskiy, 2014, 2016). Date of construction excavations, 2015-29-28 BC (Ki-192174170 \pm 30 BP 2876-2676 BC). Signs of its entry into the cultural layer were caught above the carbonate horizon. This late date for the complex of the Maikop-Novosvobodnaya community allows us to put the question of its finale in the Black sea area at the beginning of the III Millennium BC.

How can now be considered the stratigraphy of the settlement Gulyaevskoie 1? Comparing all the data on the stratigraphy of finds on this settlement, we can say that there are finds directly lying in the carbonate layer, and finds found significantly above the carbonate layer. Date 34-32 BC came from a bone sample taken near the later buildings of the 1991 excavations. As dated on the settlement Gulyaevskoie 1 level layer of carbonates - the question remains open. According to the stratigraphy of this settlement, it can be said that the deposition of the carbonate layer could go directly to fill the garbage pits (Fig. 118).

On the other Gulyaevskoie III settlement date on animal bone was significantly older than in the range $40-37 \mathrm{BC}$ That is, it may indicate an earlier time of emergence of the holders of MNC in this place, and founded another monument, not a settlement Gulyaevskoe 1.

Thus, now it can be considered that the existence of carriers of the culture of MNC and its early variant in the Caucasus was long. It is stretched from $40 / 37$ centuries BC to $34-30$ centuries BC and in some places up to the beginning of the III Millennium BC. The statement that thin layers of the Maikop's settlements signify the brevity of the existence of the Maikop culture is illegal (Rysin, 2012. P. 215).

Second block. According to palynological and fitolit analyses the emergence of the Maikop tribes near the settlement of Tuzla-15 occurred in the conditions of change arid climate of the steppes more humid conditions, leading to the formation of carbonate deposits in the thickness of the chestnut soils. Traces of the same phenomenon was previously recorded in the settlement Gulyaevskoie 1 and Checon (Koreneuskiy, 2018. P. 89-91), as well as on a number of other objects of the time of the Maikop culture that arose on chestnut soils. These data allow us to believe that the migration of the tribes of 
the Maikop-Novosvobodnaya community had primarily economic reasons related to climate change. Such changes could have a very broad impact on migration movements of ancient cultures and cause the emergence and disappearance of historical and cultural phenomena (Korenevskiy, 2005)

Third block. The materials of the settlement Tuzla-15 it is possible to use to characterize the economic-cultural type of the local tribes of the Psekupskiy variant. First of all, we can say that the localization of the monument is typical for most carriers of the culture of MNC. It is associated with living at a water source in the river valley. In this case - near the sea coast. Cultural layer with a capacity of about half a meter indicates settlement. However, such settlement could be in the nature of temporary residence, care and return to the habitable place. An indicator of this way of life on the monument is the weak saturation of the cultural layer in the space between dwellings.

Many animal bones associated with the traces of the feast were found in the filling of the halfearthen huts. The collection is dominated by sheep bones, then cower bones are steadily represented by pig bones. There are bird bones, fish bones, and whole collections of oyster flaps. Its are single finds of horse bones. In all likelihood, the discovered osteological remains were the waste of large meals, which were accompanied by the ritual acctions of the abandoned building.

On the agriculture of the Maikop variant and the Psekupskiy variants could indicate a bronze hoes and numerous grinders, inlays, sickles, found on the settlements. Grown Maikop, hard to say, but still at tribes of local Chalcolithic was famous varieties of wheat and barley (Ostashinsky etc., 2016). In the use of plant food, reeds that grew in abundance along the banks of rivers could be of great importance. An important food resource in ancient times based on cane is well evidenced by the Ingush epic and the practice of nutrition in survival conditions with limited resources of cereals (Tsaroeva, 2014. P. 78; Pavlov, 1942).

Hoe farming quickly led to the depletion of soil fertility and pushed to new habitats in search of more fertile land, as suggested by an authority on the agrarian culture of the tribes of the Bronze Age by I. Kikvidze (Kikvidze, 1987). In relation to the development of cattle breeding is a leading specialist in this field V.M. Shamiladze wrote: "the
Caucasus was not a cradle of nomadism or the area of the early nomads" (Shamiladze, 1982. P. 70, 76). True nomadism, or nomadism, as a model of cattle farming took shape mainly with the domestication of the horse for riding.

In summary, the data obtained can confirm the idea in the definition of economic-cultural type of the Maikop tribes, as the mobile-sedentary agriculture, pastoralists and farmers (Korenewskiy 2004. P. 71-77). Carriers of different variants of the MNC could have their own specifics and specialization. The Maikop tribes were peculiar to the hospital and mobility. Cattle could graze on pastures along river valleys and be kept in stables. The population could engage in hunting, gathering and hoe farming. In the Black sea zone, the feature of local tribes could be the use of shells and fish for food. It was a good additional food resource.

Fourth block. The increase in sources on the settlements of the Pskupskiy variant of MNC in the Black sea area, the establishment of the phenomenon of ritualisierungen procedure of throwing of abandoned dwellings, the use of pits, the size of dwellings-huts for the occasional allocation of deceased persons, burial of relatives in the cultural layer of the settlement - all of these observations allow us to formulate and solve questions who were carriers of the Psekupskiy variant in the Black sea area and how they were similar or differed from the population of MNC more eastern regions of the Before Coucasus valleys.

Fifth block. The literature repeatedly emphasized the proximity of the ceramic complexes of the Maikop culture has analogies between ceramic complex of the Leilatepe culture of the southern Caucasus (Museibli, 2011). This provision is more only in line with the Maikop variant of the Maikop-Novosvobodnaia community. When we begin to compare ceramic of complexes from settlements Tuzla-15 and Checon with ceramics of the Leilatepe culture it is possible to fix the obvious peculiarity of the Black sea monuments. They are not observed ceramics 1 class, with the marks, found painted ceramics, which are poorly documented the similarities between those ceramics collections. It is difficult to talk about the identity of hand - made ceramics of the South Caucasian and Black sea monuments. Therefore, these differences will need to be explained in the future when comparing the materials under consideration become more rich and submit a wider background for analogies. 


\section{ЛИТЕРАТУРА}

Ахундов Т.И., 2014. Алхантепе-поселение начала бронзового века в Азербайджане // Записки Института материальной культуры РАН. № 10. СПб. С. 78-92.

Березин С.Я., 2008. Отчет о раскопках поселения Стодеревское-1, курганных могильников Шефтовский 1, 2, 3, 4, Стодеревская 14 Курского района Ставропольского края в 2008 году. Ставрополь // Архив ИА PAH P-1.

Бобринский А.А., 1978. Гончарство Восточной Европы. М.: Наука. 272 с.

Бонин A. B., 2013. Отчет об охранных археологических исследованиях 2010 г. на поселении Чекон I в г. -к. Анапе и Мерчанское I в Крымском районе Краснодарского края, расположенных в зоне строительства ВЛ 220 кв. по титулу «ВЛ 220 кв Крымская-Вышестебливская» и «ВЛ 220 кв «СлавянскаяКрымская 2» М. Архив ИА РАН № 34098.

Бонин А. В., Бейлин Д. В., Сударев Н. И., 2013. Чекон-1 - поселение бронзового века в Армавирском райне. Древности Боспора. Вып. 17. Краснодар. С. 9-20.

Бочковой и др., 2012. Бочковой В.В., Марченко И. И., Лимберис Н. Ю., Резепкин А. Д., Поселение майкопской культуры «Чекон» // Древние культуры степей Евразии и их взаимодействие с цивилизациями. СПб.: С. 7-20.

Бочковой В.В., Марченко И.И., Лимберлис Н. Ю., Резепкин А.Д., 2012. Материалы поселения Чекон и классификация керамики майкопской культуры // Культуры степей Евразии и их взаимодействие с древними цивилизациями ИИМК РАН. СПб.

Бочковой В. В., 2013. Отчет Краснодарской археологической экспедиции о раскопках поселения Чекон и кургана у с. Юровка в 2011 г. в 6 томах. Краснодар // Архив ИА PAH P-1 № 29344.

Бочковой В.В., Марченко И.И., Лимберлис Н. Ю., Резепкин А. Д., 2013. Поселение майкопской культуры Чекон // Археология и этнография понтийско-кавказского региона. Краснодар. С. 5-18.
Булах E. Н., 2014. Полуземлянки поселения Чекон // Анфимовские чтения по археологии западного Кавказа. Краснодар. C. 30-36.

Гей А.Н., З Зазовская Э.П., 2013. Новые радиокарбонные даты поселения Мысхако и майкопского поселения Чекон // Международная кубанская археологическая конференция. Отв. ред. Марченко И.И. Краснодар. С. 81-84.

Глонти Л.И., Джавахишвили А.И., 1987. Новые данные о многослойном памятнике эпохи энеолита поздней бронзы в Шида Картли - Бериклдееби // КСИА, Вып. 192. C. $80-86$

Головнев А.В., 2019. Слитное пространство-время в движении кочевников Арктики // Мобильность и миграция: концепции, методы, результаты. Новосибирск: Изд. ИАЭТ СО РАН. С. 33-36

Днепровский К.А., 1991. Серегинское поселение эпохи ранней бронзы // Древности Северного Кавказа и Причерноморья. M. C. $3-15$

Днепровский К.А., Яковлев А.А., 1988. Новое поселение эпохи ранней бронзы в Закубанье // Материальная культура Востока. Часть 1. М. С. 89-99.

Дъяконов И. М., 1979. Предисловие // Фридрих И. История письма. М.: Наука. C. 9-29.

Дъяконов И. М., 1983. История Древнего Востока. Зарождение древнейших классовых обществ и первые шаги рабовладельческой цивилизации. Ч. І. Месопотамия. Ред. И. М. Дьяконова. М.: Наука. 534 с.

Киквидзе Я.А., 1987. Земледелие и земледельческий культ в древней Грузии. Тбилиси: Мицниереба. 267 с.

Кипиани Г., 1997. Бериклееби // Вестник государственного музея Грузии им. академика Джавахишвили. XLII-B. Тбилиси. C. $13-41$.

Кияшко Ю.Г., 2019. Поселение Орлов Ерик - новый памятник майкопско-новосво- 
бодненской общности на Северном Кавказе // «Феномены культур энеолита - раннего бронзового века степной и лесостепной полосы Евразии: пути культурного взаимодействия в V-III тыс. до н. э.» (тезисы конференции Оренбург, 16-19 апреля 2019 г.). Оренбург. С. 10

Кореневский С. Н., 1995. Галюгай 1 - поселение майкопской культуры. Изд. Ин-та этнологии и антропологии. М. 188 с.

Кореневский С.Н., $1998 . \quad$ Поселение «Замок» у города Кисловодска (нижний слой) // Материалы по изучению историко-культурного наследия Северного Кавказа, выпуск 1. Археология. Ставрополь. C. $96-150$.

Кореневский С. Н., 2004. Древнейшие земледельцы и скотоводы Предкавказья. Майкопско-новосвободненская общность, проблемы внутренней типологии. М. 246 с.

Кореневский С.Н., 2005. Ориентация культур древнейших земледельцев и скотоводов эпох энеолита - раннего бронзового века Кавказа и Подунавья в системе схемы Блитта-Сернандера // Древности Кавказа и Ближнего Востока. Махачкала. С. 67-119.

Кореневский С.Н., 2008. Современные проблемы изучения майкопской культуры // Археология Кавказа и Ближнего Востока. М.: Таус. С. 71- 122.

Кореневский С.Н., 2011. Древнейший металл Предкавказья. Типология. Историкокультурный аспект. М.: Таус. 385 с.

Кореневский С.Н., 2011а. Феномен власти в обществах древних земледельцев и скотоводов (теория этнологии и археологии) // КСИА. Вып. 225. С. 175-188.

Кореневский С.Н., 2013. Культ жилища и очага у племен майкопско-новосвободненской общности (к проблеме символики обитаемого пространства) // Stratum plus. № 2. Обитаемое пространство в Европейской Преистории. Кишинев. С. 103-131.

Кореневский С.Н., 2013а. О понятиях цивилизация и протоцивилизация и знаках на керамике в культурах Подунавья и Кавказа и Переднего Востока в V-III тыс. до н. э. // КСИА. Вып. 230. С. 63-84.

Кореневский С.Н., 2014. Отчет о раскопках поселения Тузла-15 Темрюкского района
Краснодарского края в 2013 году // Архив ИА РАН Р-1 № 40750.

Кореневский С.Н., 2015. Отчет о разведках культурного слоя на поселениях Тузла-15 и Чекон-1 Краснодарского края Майкопским отрядом Восточно-Боспорской экспедиции в 2014 г. // Архив ИА РАН Р-1 № 45723 .

Кореневский С.Н., 2016. Отчет о разведках культурного слоя на поселении Тузла-15 Краснодарского края Майкопским отрядом Восточно-Боспорской экспедиции в 2015 г. // Архив ИА РАН Р-1 № 47627.

Кореневский С. Н., 2016а. К вопросу о кубках и амфоровидных сосудах майкопсконовосвободненской общности и проблема их аналогий на Западе // Культурные взаимодействия. Динамика и смыслы. Сборник в честь 60-летия И. В. Манзуры. Stratum Plus. № 2. Кишинев. С. 199-226

Кореневский С. Н., 2016б. Проблемные ситуации «пост-убейдского периода» в Предкавказье (4500-3500 гг. до н.э.) // Strarum Plus. № 2. Кишинев. С. 37-62.

Кореневский С. Н., 2018. Общее представление о климатических переменах в равнинном Предкавазье в эпоху начала медно-бронзового века второй половины V-IV тыс. до н.э. // Археология и естественные науки в изучении культурного слоя объектов археологического наследия. М.: Изд. Инст. археологии РАН. С. 89-91.

Кореневский. С.Н., 2018а. На пороге цивилизации. Майкопско-новосвободненская общность. Западный Кавказ (обзор новых источников и проблема протоцивилизации) // Материалы и исследования по археологии Северного Кавказа. АрмавирКраснодар. С. 7-43

Кореневский С.Н., $\quad$ СударевН.И., 2013. Разведочные раскопки поселения Тузла-15 в 2012 году // Шестая Международная кубанская археологическая конференция. Краснодар. 2013. С. 196-199.

Кореневский С.Н., К вопросу об изучении технологии изготовления керамики майкопско-новосвободненской общности по методике А.А. Бобринского и новые эксперименты // Самарский научный вестник. Самара. С. 59-70. 
Кореневский С.Н., Медникова М.Б., Бочковой В. В., 2015. Новые данные о разнообразии погребальных обрядов майкопско-новосвободненской общности // Археология, этнография и антропология Евразии. Том 43, № 2. Новосибирск. С. 34-42.

Кореневский С.Н., Медникова М. Б., Добровольская М. В., Яиюк Д. А., 2019. Майкопские погребения могильника Ольховский // Горы Кавказа и Месопотамская степь на заре бронзового века. Сборник в честь 90-летия Р. М. Мунчаева. М.: Изд. ИАРАН С. 73-89.

Кореневский С.Н., Кизилов А.С., 2015., Общие сведения об изготовлении керамики майкопско-новосвободненской общности и моделирование следов поворотного устройства // КСИА. Вып. 239. С. 195-210.

Кореневский С.Н., Давудов Ш.О., 2019. Поселение эпохи раннего бронзового века у станицы Старотитаровской Краснодарского края и найденное на нем погребение // КСИА. Вып. 255. С. 127-139.

Кореневский С.Н., Спиридонова Е.А., Сударев Н.И., 2019. О климате времени майкопского поселения Тузла-15 на Таманском полуострове (предварительное сообщение) // Материалы и исследования по археологии Северного Кавказа. Вып. 17. Армавир-Краснодар: ООО Наследие Кубани. С. 3-15.

Кореневский С. Н., Юдин А. И., 2019. Поселения майкопско-новосвободненской общности Тузла-15 и Чекон: особенности культурного слоя и стратиграфия // Феномены культур раннего бронзового века степной и лесостепной полосы Евразии: пути культурного взаимодействия в V-III тыс. до н. э. Оренбург:: Изд. Оренбургский государственный Университетю. С. 60-69.

Молодин В.И., 2019. Основные типы миграции и их проявления в эпоху бронзы на юге центральной части Западно-Сибирской равнины (Обь-Иртышье) // Мобильность и миграция: концепции, методы, результаты. Новосибирск: Изд. ИАЭТ СО РАН. C. 60-64.

Мунчаев Р. М., 1975. Кавказ на заре бронзового века. М.: Наука. 416 с.

Мунчаев Р. М., Нечитайло А. Л., 1966. Комплексы майкопской культуры в Усть-Джегутинском могильнике // СА, № 3. С. 131-151.
Мусеибли Н.А., 2007. Беюк Кесик. Баку.: Nafta-Press. 227 c.

Мусеибли Н.А., 2011. Лейлатепинская археологическая культура: переднеазиатские корни и место в кавказском энеолите // Apхеология и этнография в Азербайджане. Вып. 2. Баку (на азербайджанском языке). C. 1-29.

Нечитайло А. Л., 1978. Верхнее Прикубанье в бронзовом веке. Киев.: Наукова думка. 147 c.

Осташинский С.М., Черленок Е.А., Лоскутов И. Г., 2016. Новые данные о древнем земледелии Северо-Западного Кавказа // Археологические вести. СПб. № 22. С. 35-40

Павлов Н. В., 1942. Дикие полезные и технические растения СССР М.: Казах. гос. ун-т им. С. М. Кирова. Казах. филиал Акад. наук CCCP. 642 c.

Потехин И.И., Военная демократия матабеле // Родовое общество. Этнографические материалы и исследования. М., 1951. С. 34.

Резепкин А.Д., 2004. Поселение эпохи ранней бронзы Чишхо и некоторые аспекты происхождения и хронологии майкопской культуры // Археолог: детектив и мыслитель. Сборник статей, посвященный 77-летию Льва Самойловича Клейна. СПб. C. $422-436$.

Резепкин А. Д., 2008. Поселение Новосвободненское // Археология Кавказа и Ближнего Востока. Отв. ред. Н.Я. Мерперт, С.Н. Кореневский. М.: Таус, С. 156-176.

Резепкин А. Д. 2012. Новосвободненская культура (на основе материалов могильника «Клады»). СПб.: Нестор-История, 2012. C. 342.

Резепкин А.Д., 2013. Поселение Новосвободненское на северо-западном Кавказе // Записки Института истории материальной культуры. Изд. ИИМК. Вып. 10. СПб. C. 93-103.

Резепкин А.Д., 2013а. Поселение УстьДжегутинское // Материалы по изучению историко-культурного наследия Северного Кавказа. Вып. XI. Археология, краеведение, музееведение. Ред. Белинский А. Б. Изд. Памятники исторической мысли. М. С. 39-70.

Резепкин А. Д., Лионе Б., 2007. Поселения эпохи ранней бронзы на Кубани // Revista 
Arheologică, seria nouva, vol. III, № 1-2. Chişinău. C. 5-73.

Риттер Э., 1989. Зулус Чака. Возвышение зулусской империи. М.: Издательство восточной литературы Наука. 194 с.

Рысин М.Б., 2012. Проблемы хронологии и периодизации древних культур Кавказа (радиокарбонная «революция» и традиционная типология // Археологические вести. СПб. Вып. 18. 2012. С. 204-231.

Савинов Д. Г., 2019. Ранние скотоводы восточной части евразийских степей (в свете антропологии движения А. В. Головнева) // Мобильность и миграция: концепции, методы, результаты. Новосибирск.: Изд. ИАЭТ CO PAH. C. 94-97.

Сударев Н. И., 2013. Отчет о проведении археологических разведок на территории г. -к. Анапа, г. Славянск-на-Кубани Славянского района и в Темрюкском районе Краснодарского края в 2012 г. М. // Архив ИА PAH. P-1 № 35481.

Тэйлор Э., 1939. Первобытная культура. М.: «Госсоцэкгиз». 1939.568 с.

Тов А., 2013. Некоторые особенности майкопских поселений степной Адыгеи // Problems of the Maykop culture in the Context of Caucasian-Anatolian Relations Tbilisi. P. 159-167.

Торосян Р. М., 1976. Раннеземледельческое поселение Техут. Ереван: Изд-во АН Армянской ССР. 140 с.

Трифонов В.А., 2014. Западные пределы распространения майкопской культуры // Известия Самарского научного центра Российской академии наук. Том 16, № 3. Самара. С. 276-284.

Цароева М., 2016. Пантеон ингушей. М.: Триумф. 543 с.

Шамиладзе В. М., 1982. О некоторых вопросах классификации и терминологии скотоводства Кавказа // Советская этнография. Вып 2, май-июнь. М. С. 70-76

ШишлинаН.И., Ларионова Ю.О., Эрлих В.Р., Ковалев Д. С., ван дер Плихт Й., 2015. Погребение майкопской культуры из могильника Синюха: результаты изотопного исследования // КСИА. Вып. 238. С. 262-275.

Шишлов А.В., КолпаковаА.В., Федоренко И.В., 2007. Работы Новороссийского исторического музея-заповедника в 2007 году // АО. 2007. М. С. 328-331.

Шишлов А. В., Федоренко И. В., 2008.Памятники майкопской культуры в Приморской части предгорий Северо-Западного Кавказа // Наследие Кубани. Вып. 1. Краснодар. C. $118-127$.

Шишлов А.В., Колпакова А.В., Федоренко И.В., Каноненко А. П., 2009. Погребения майкопской культуры у станицы Натухаевской // Пятая Кубанская археологическая конференция. Краснодар. С. 443-447.

Шишлов А.В., Колпакова А.В., Федоренко И. В., 2010. Исследования поселения майкопской культуры уст. Натухаевской // Проблемы хронологии и периодизации археологических памятников и культур Северного Кавказа (тезисы докладов). Магас. C. $374-377$.

Шишлов А.В., К Колпакова А.В., Федоренко И.В., 2013. Исследования поселения майкопской культуры у ст. Натухаевской в 2007 году // Третья Абхазская международная конференция. Проблемы древней и средневековой археологии Кавказа. Сухум. С. 89-98.

Шишлов А. В., 2012. Исследование майкопских памятников в районе Новороссийска. Доклад, прочитанный на заседании Отдела археологии Бронзового века 20 сентября 2012 в Институте археологии РАН (ссылки на демонстрируемые материалы делаются с разрешения автора доклада).

Шишлов А.В., Колпакова А.В., Федоренко И.В., 2013. Орнаментация краской керамики на памятниках майкопской культуры в Приморской части предгорий Северо-Западного Кавказа // Шестая Кубанская археологическая конференция. Материалы конференции. Краснодар. С. 459-470.

Шишлов А.В., К КолпаковаА.В., Федоренко И. В., 2014. Исследование поселения эпохи ранней бронзы (майкопской культуры) Катусвина Кривица-2 под Новороссийском (предварительное сообщение) // XXVIII Крупновские чтения. М. С. 112-116.

Шишлов А.В., КолпаковаА.В., Федоренко Н.В., ГейА.Н., 2015. Поселение Катусвина Кривица-2 - новый памятник майкопской культуры на Западном Кавказе 
(предварительное сообщение) // КСИА. Вып. 237. С. 113-125.

Шури Г., 1907. История первобытной культуры. СПб.: Типография Товарищества «Просвещение», 688 с.

Эрлих В.Р., Ковалев Д.С., Маслов В.Е., 2013. Погребения эпохи бронзы курганного могильника «Синюха» в Адыгее (предварительные данные) // Шестая международная археологическая конференция. Материалы конференции. Краснодар. С. 481-485.

Юдин А.И., К Кореневский С.Н., Баринов Д.Г. Раскопки поселений майкопской культуры в Краснодарском крае // АО за 2018 г. М.: Изд. ИАРАН. (в печати).
Anthony D., 1990. Migration in archaeology: the baby and the bathwater // American Anthropologist, 92 (4). P. 895-911.

BelinskijA., Hansen S., Reinhold S., 2017. The Great Kurgan from Nalčik. (A Preliminary Report) // Subartu XXXVIII At the Northern Frontier of Near Eastern Archaeology. Brepols. P. 13-32.

Cline W., 1937 Mining and Metallurgy in Negro Africa. Menasha, Wisconsin, U.S.A: George Banta Publishing Comapny. 155 p. 16 illustrations, 4 maps.

Zapotockiy M., 1992. Streitäxte des mitteleuropaischen Aneolithikums Acta Humaniora VCII. $563 \mathrm{~s}$.

\section{СПИСОК СОКРАЩЕНИЙ}
CA
PA
МИА
КСИА
$\mathrm{AO}$
$\mathrm{MHO}$
Казах. гос. ун-т

\author{
- Советская археология \\ - Российская археология \\ - материалы и исследования по археологии СССР \\ - Краткие сообщения Института археологии РАН \\ - Археологические открытия Института археологии РАН \\ - Майкопско-новосвобоненская общность \\ - Каазахстанский государственный универнситет
}


ИЛЛЮСТРАЦИИ 


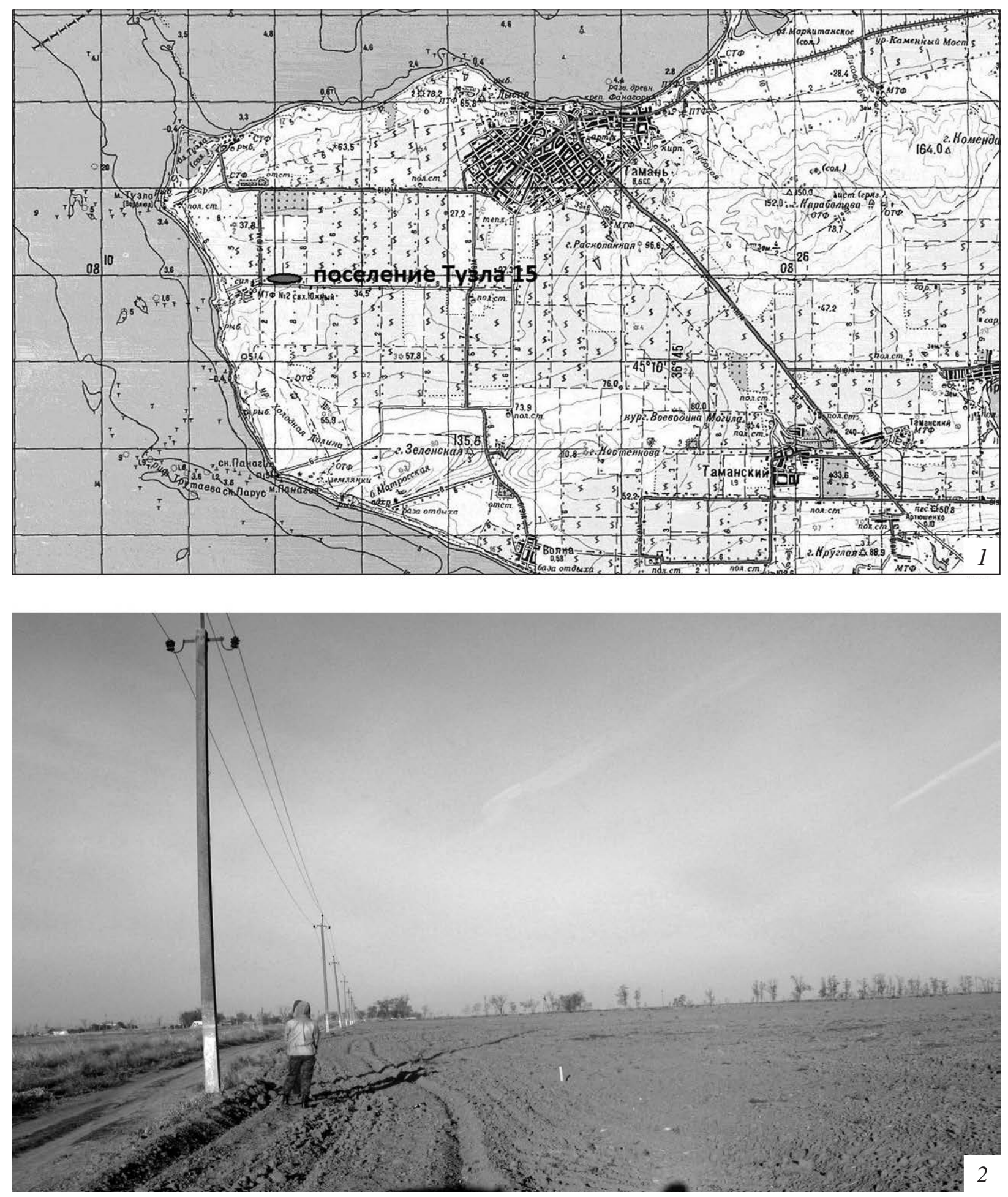

Рис. 1. Место расположения поселения Тузла-15

1 - место расположение поселения, 2 - вид на местность, на которой расположено поселение 


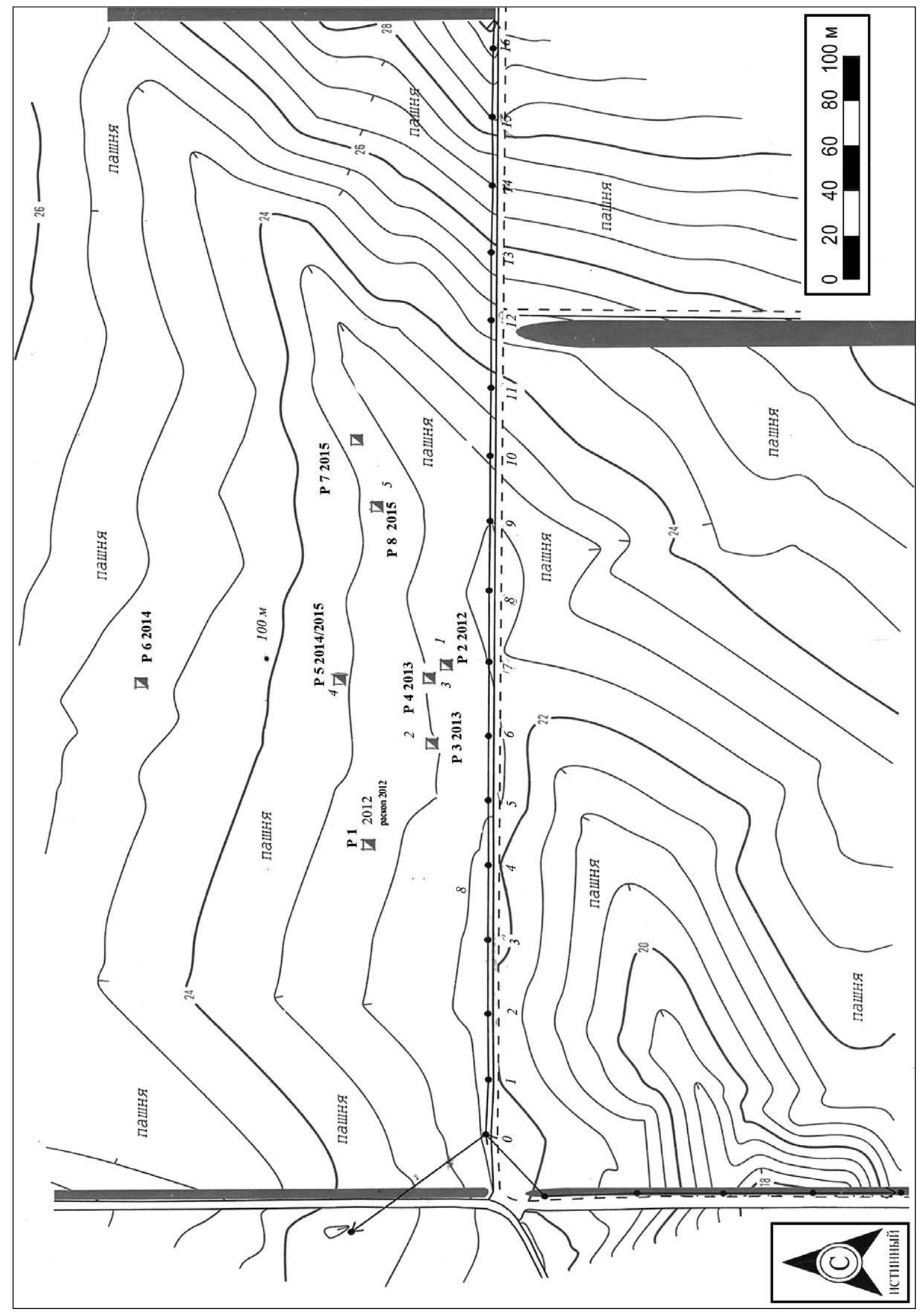

نี 

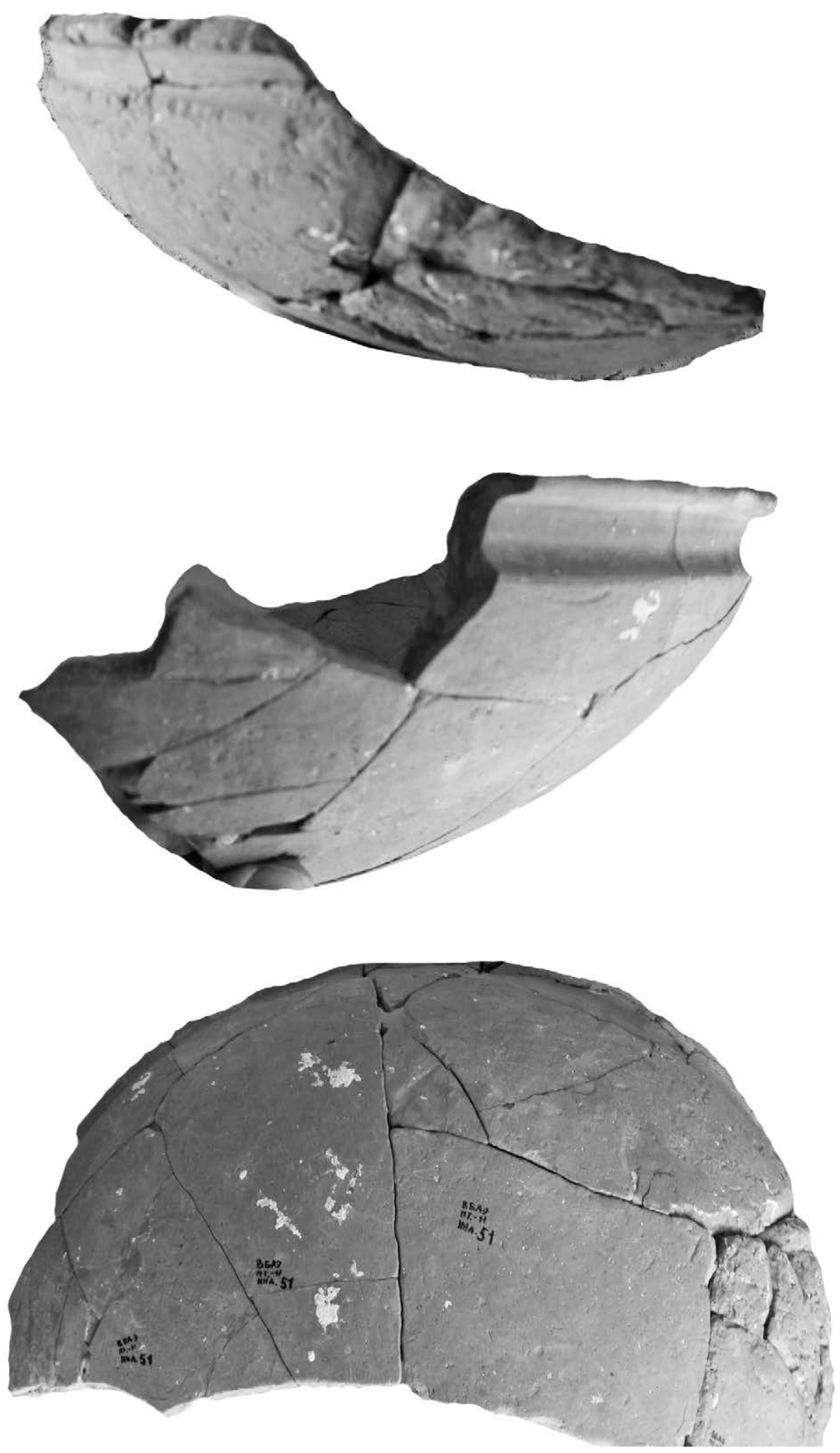

Рис. 3. Миска из раскопок С.А. Буравлева 2011 г. 

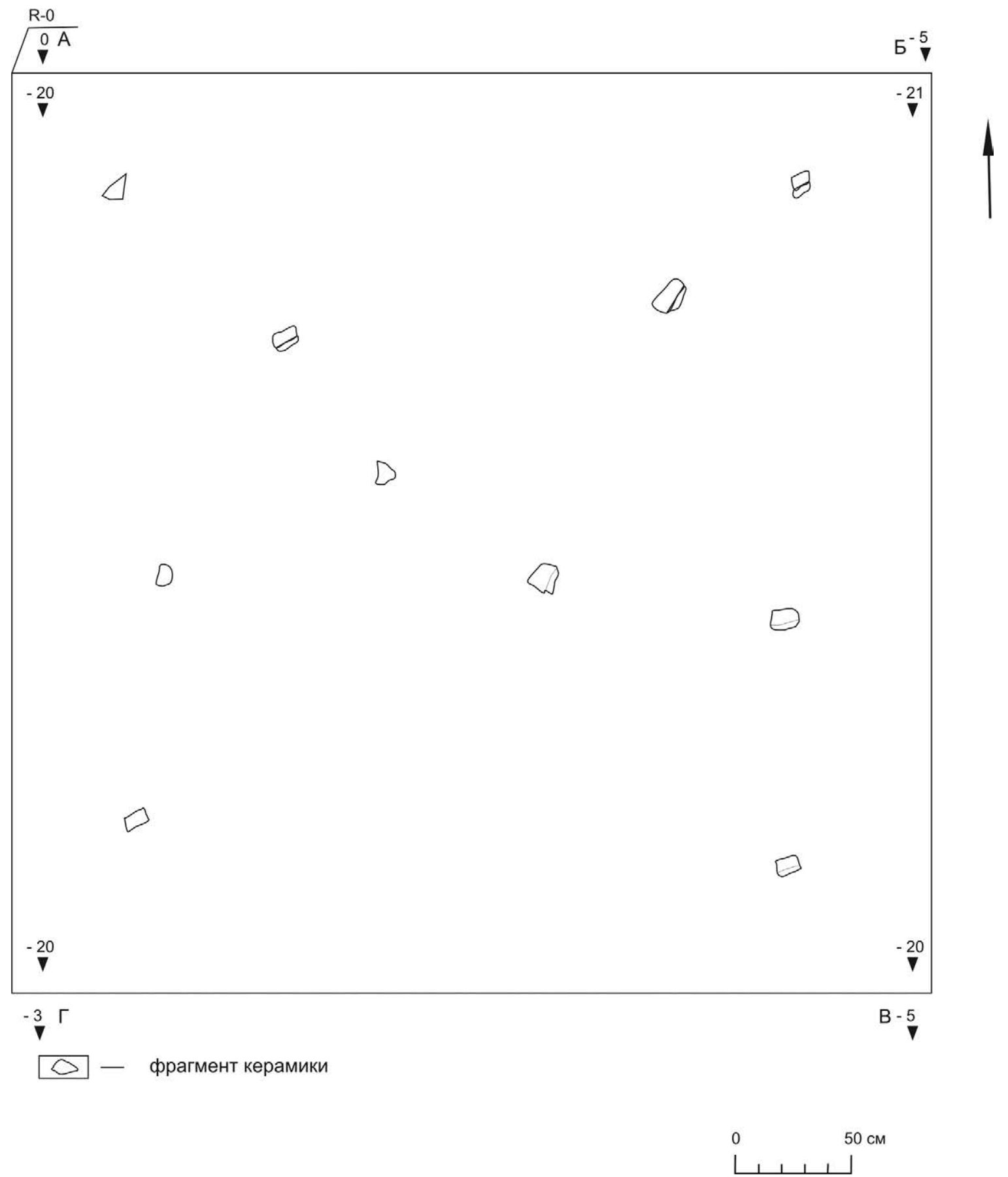

Рис. 4. Раскоп 1 (шурф 1). 2012 г. План 


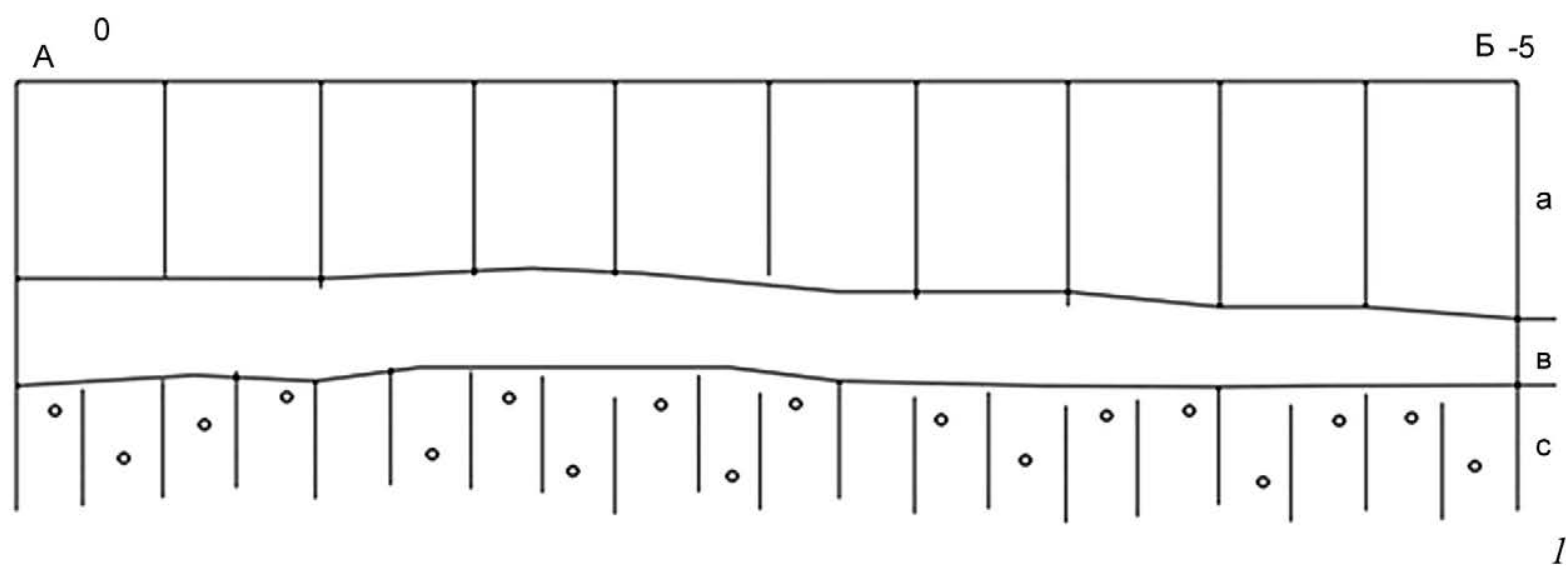

$5^{-5}$

B -3

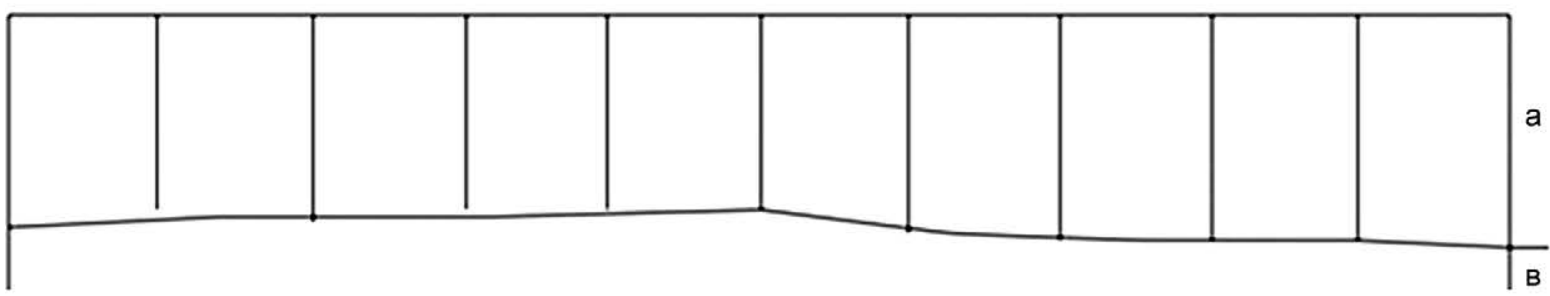

B -5

$\Gamma-3$

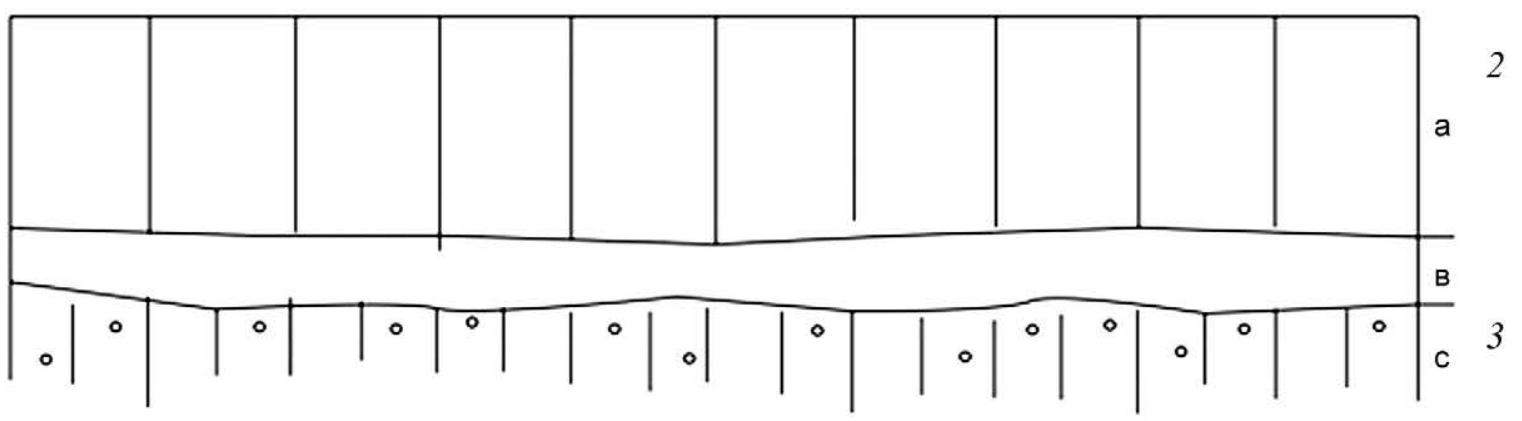

$\Gamma-3$

A 0
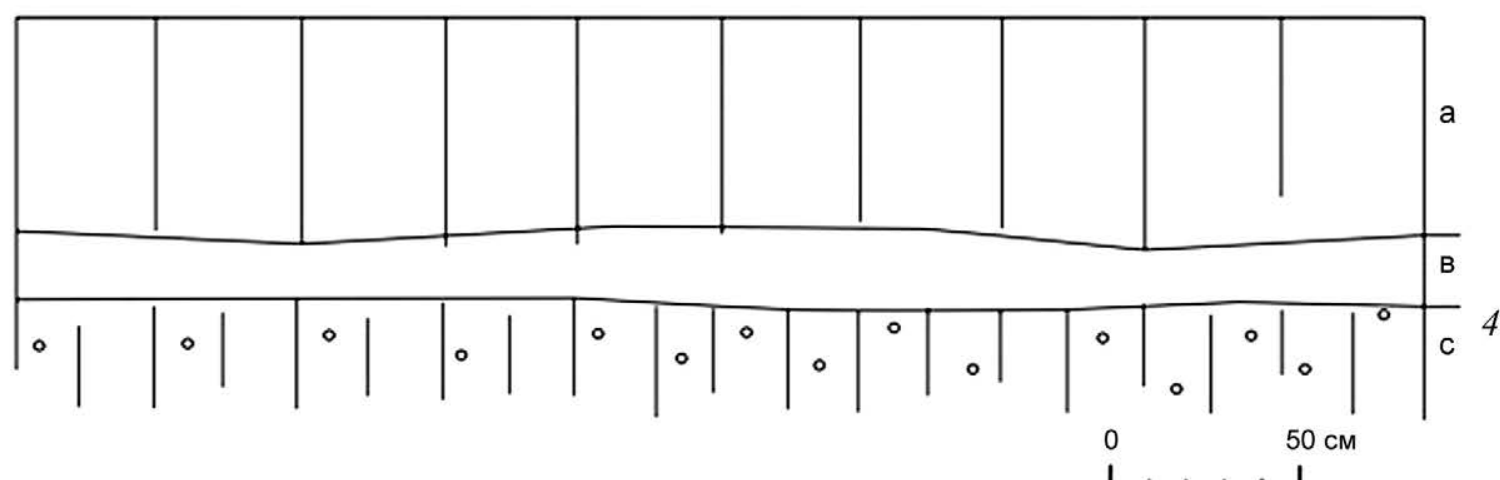

Рис. 5. Раскоп 1. 2012 г. Профили А-Б, Б-В, В-Г и Г-А

Условные обозначения:

a - слой пахоты около 60 см, рыхлый, черный

в - надкарбонатный слой, серый плотный (он же - культурный слой)

c - материковый слой, желтый суглинок с включениями карбонатов 

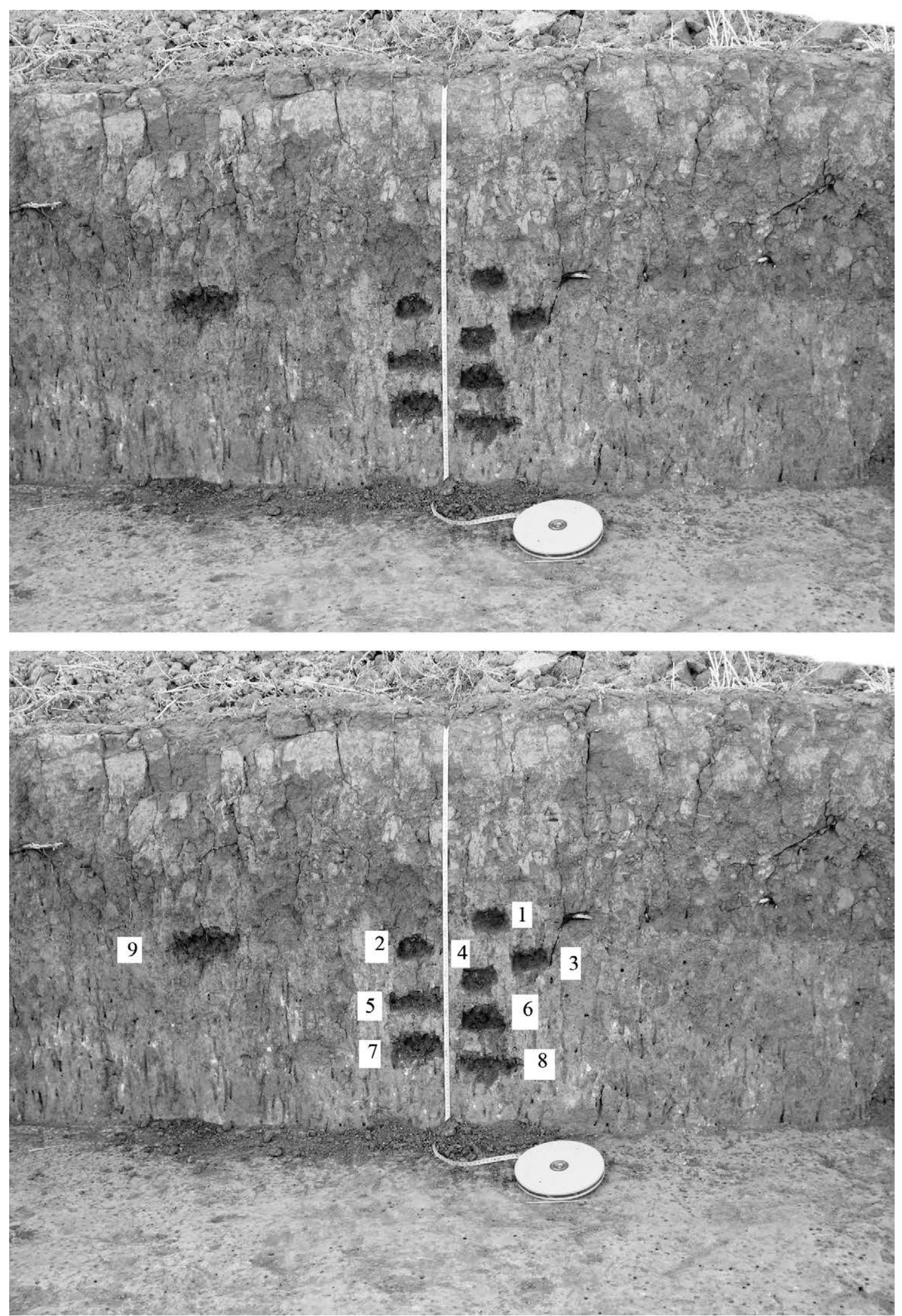

Рис. 6. Отбор палинологических проб, восточный профиль шурфа 1 

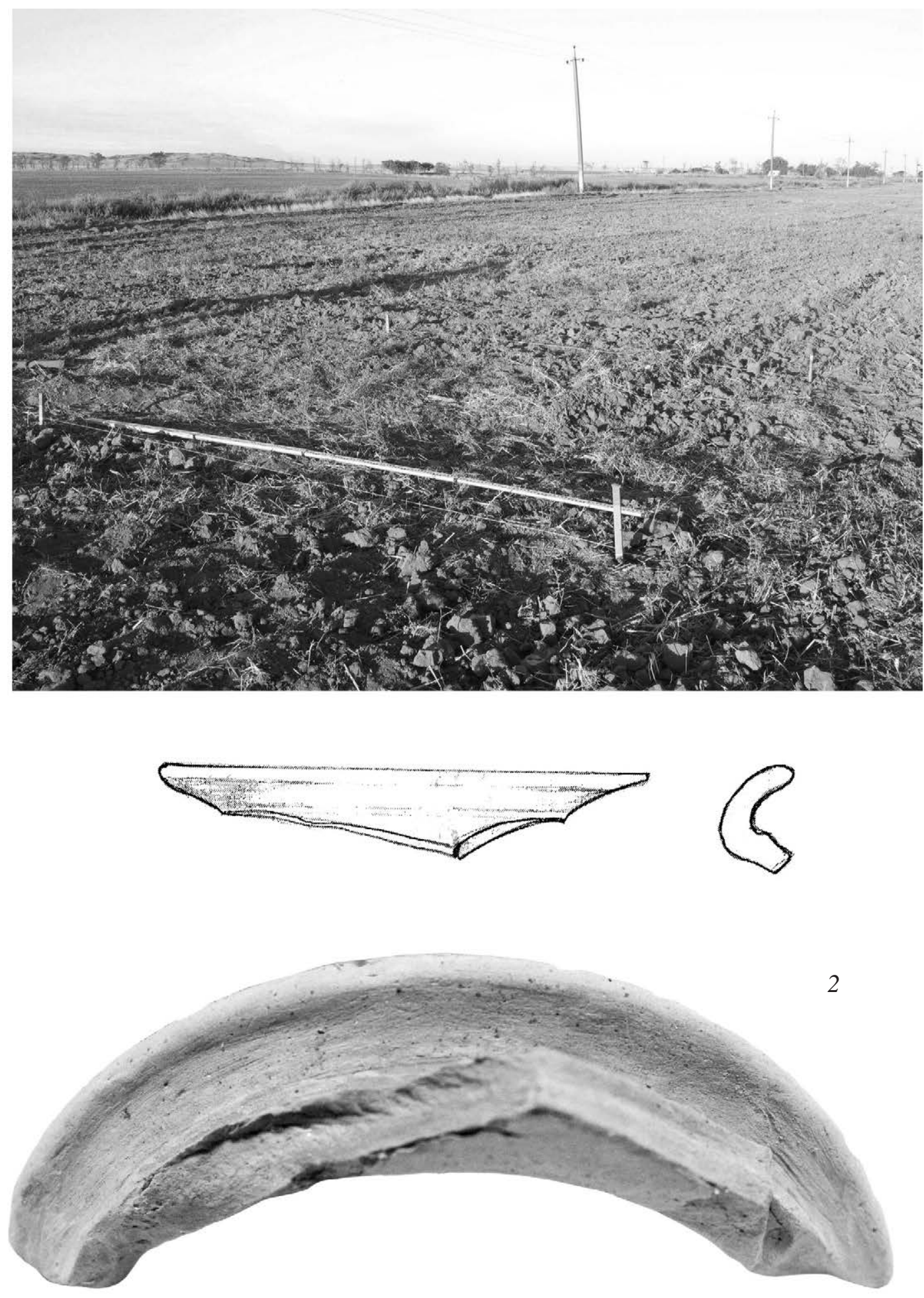

Рис. 7. Шурф 2. 2012 г. и находка венчика майкопского сосуда

1 - вид с юго-востока, 2 - венчик 


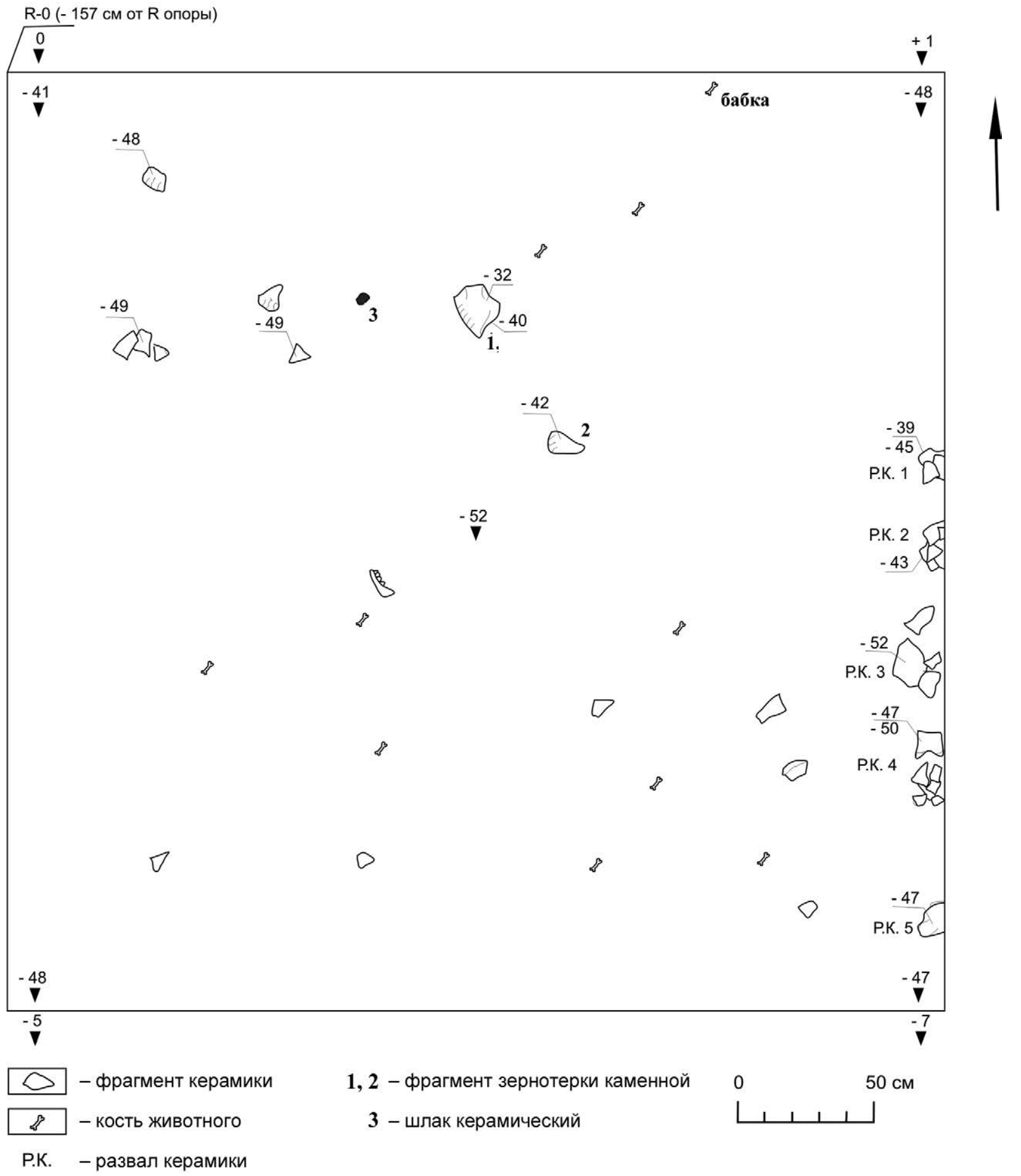

Рис. 8. Раскоп 2. 2012 г. Штыки 2 и 3 

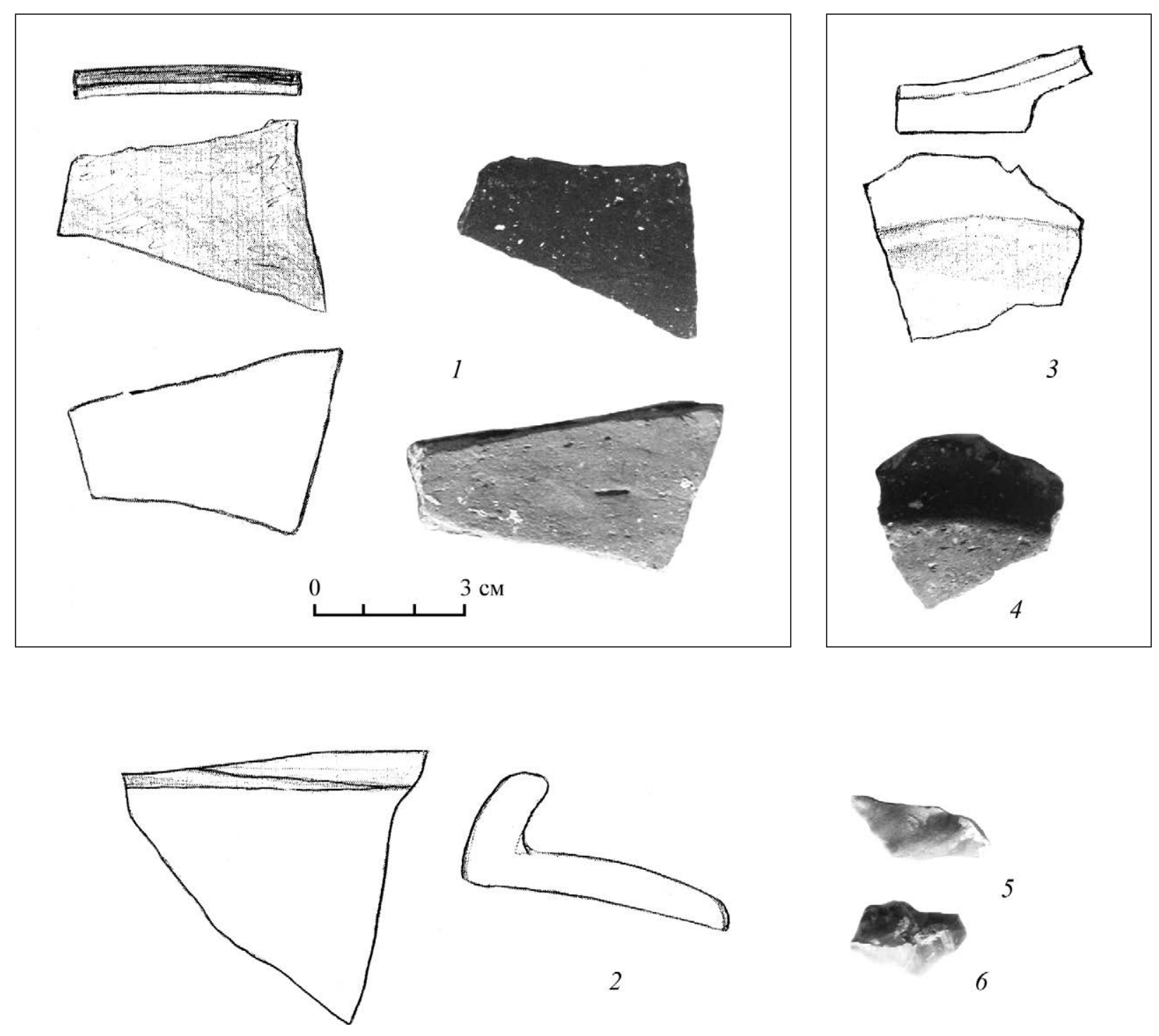

Рис. 9. Раскоп 2. 2012 г. Находки 

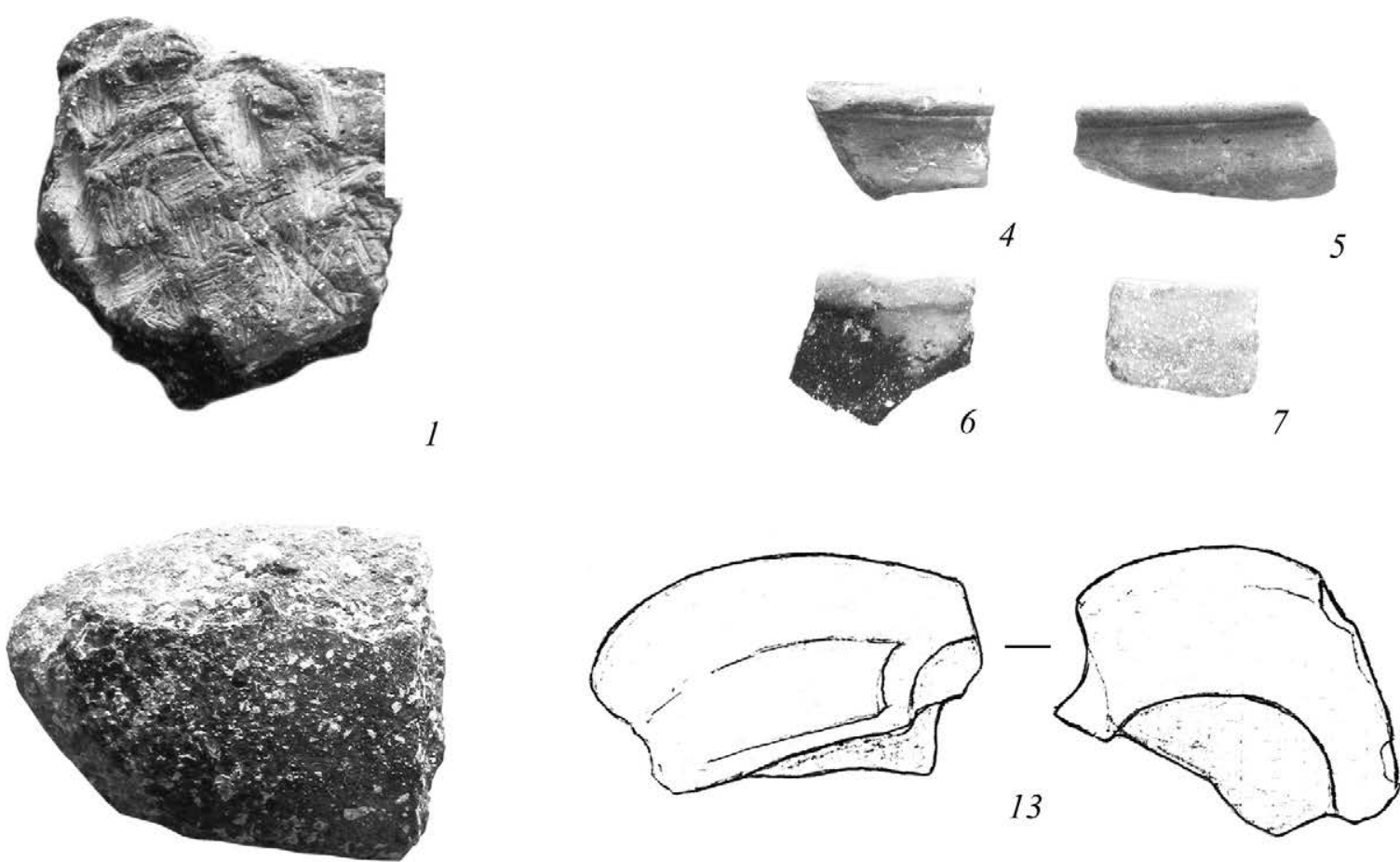

2
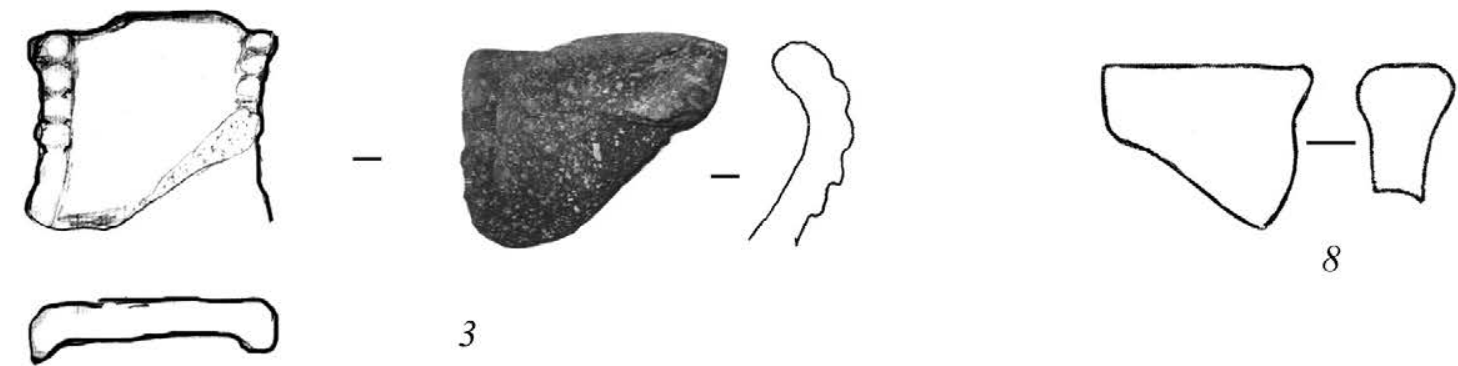

3
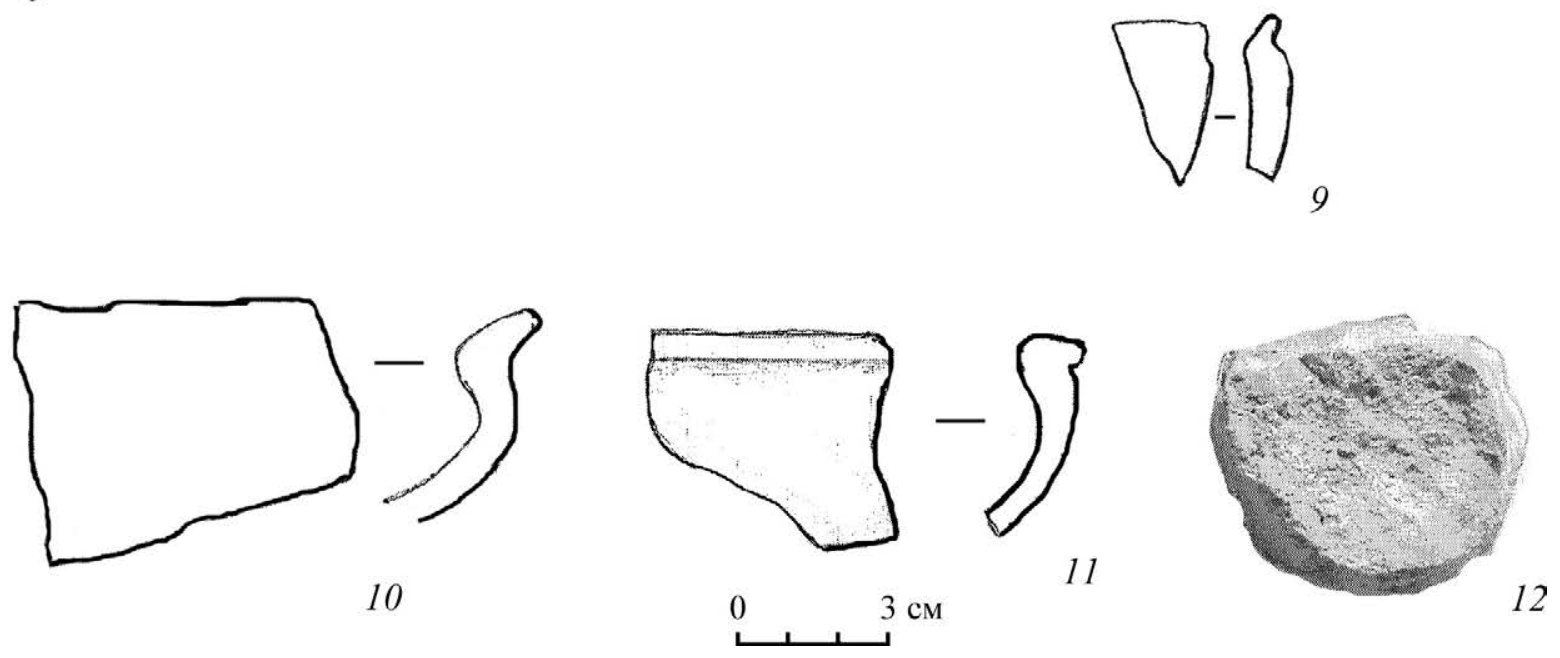

Рис. 10. Раскоп 2. 2012 г. Находки 


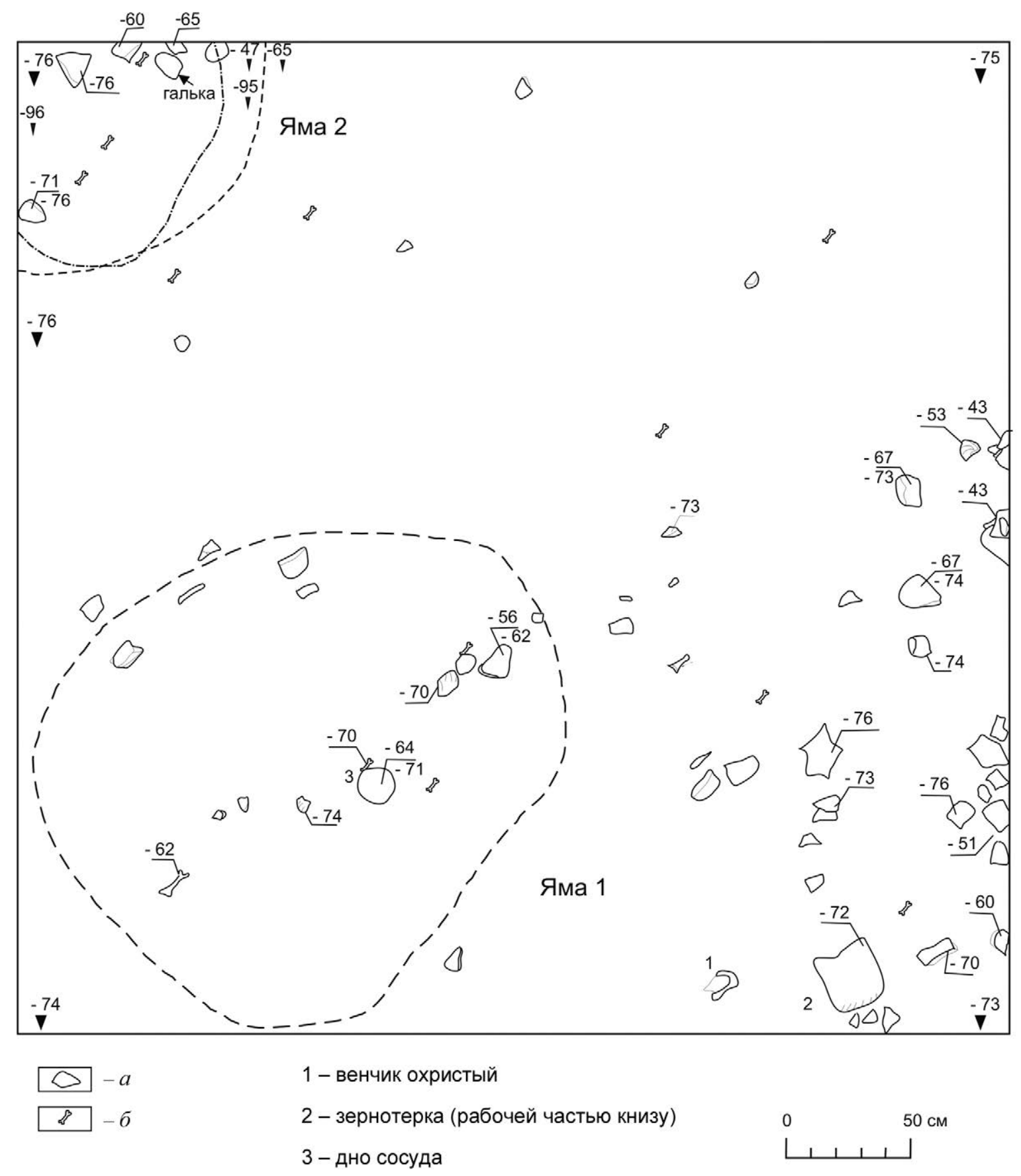

Рис. 11. Раскоп 2. 2012 г Штык 4. План

Условнъе обозначения:

$a$ - фрагмент керамики, б- кость животного 

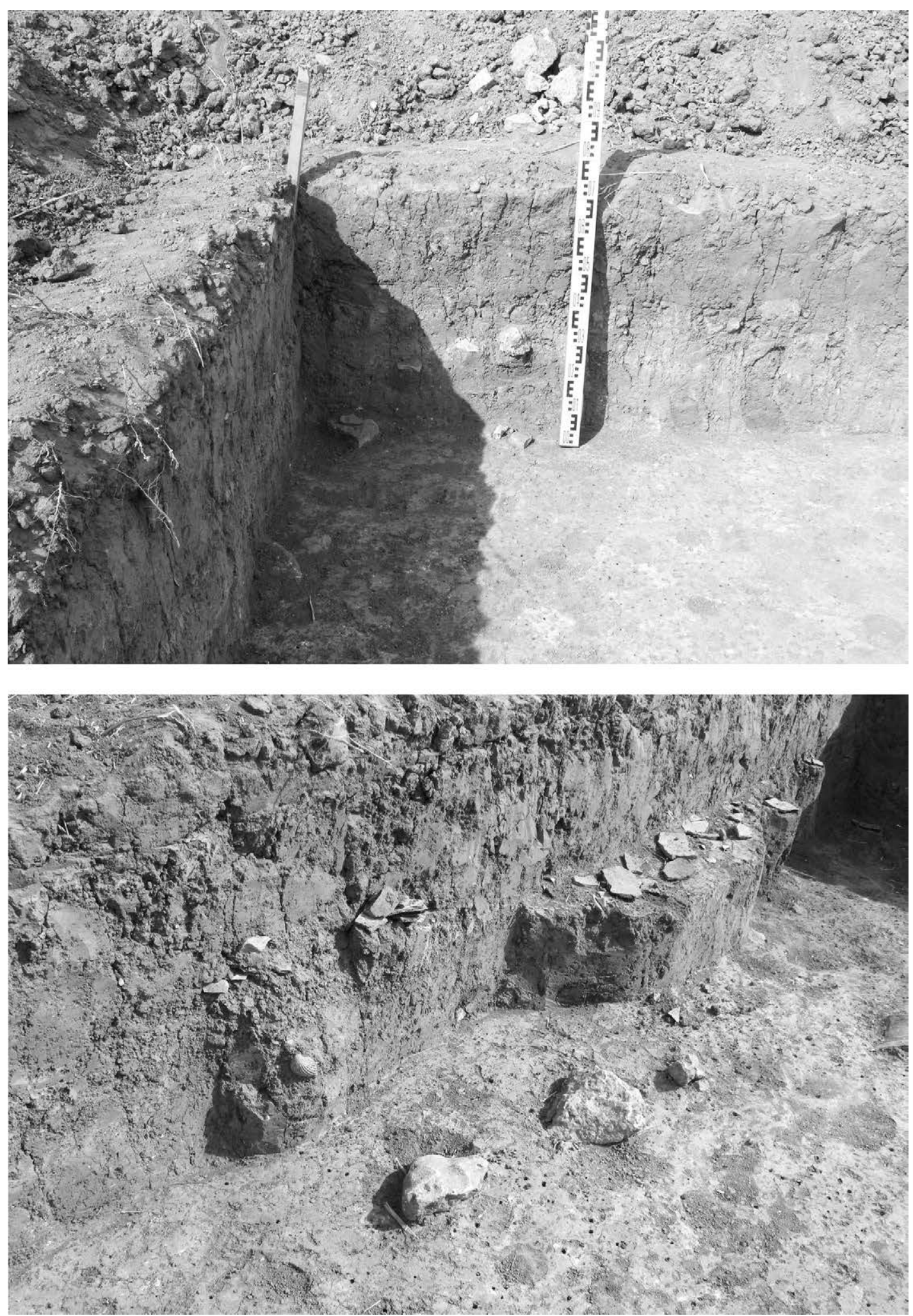

\section{Рис. 12. Раскоп 2. 2012 г. Фрагменты работ}

1 - зачистка 4 штыка, вид с юга на западный угол квадрата, 2- вид с севера на юго-восточный угол квадрата 

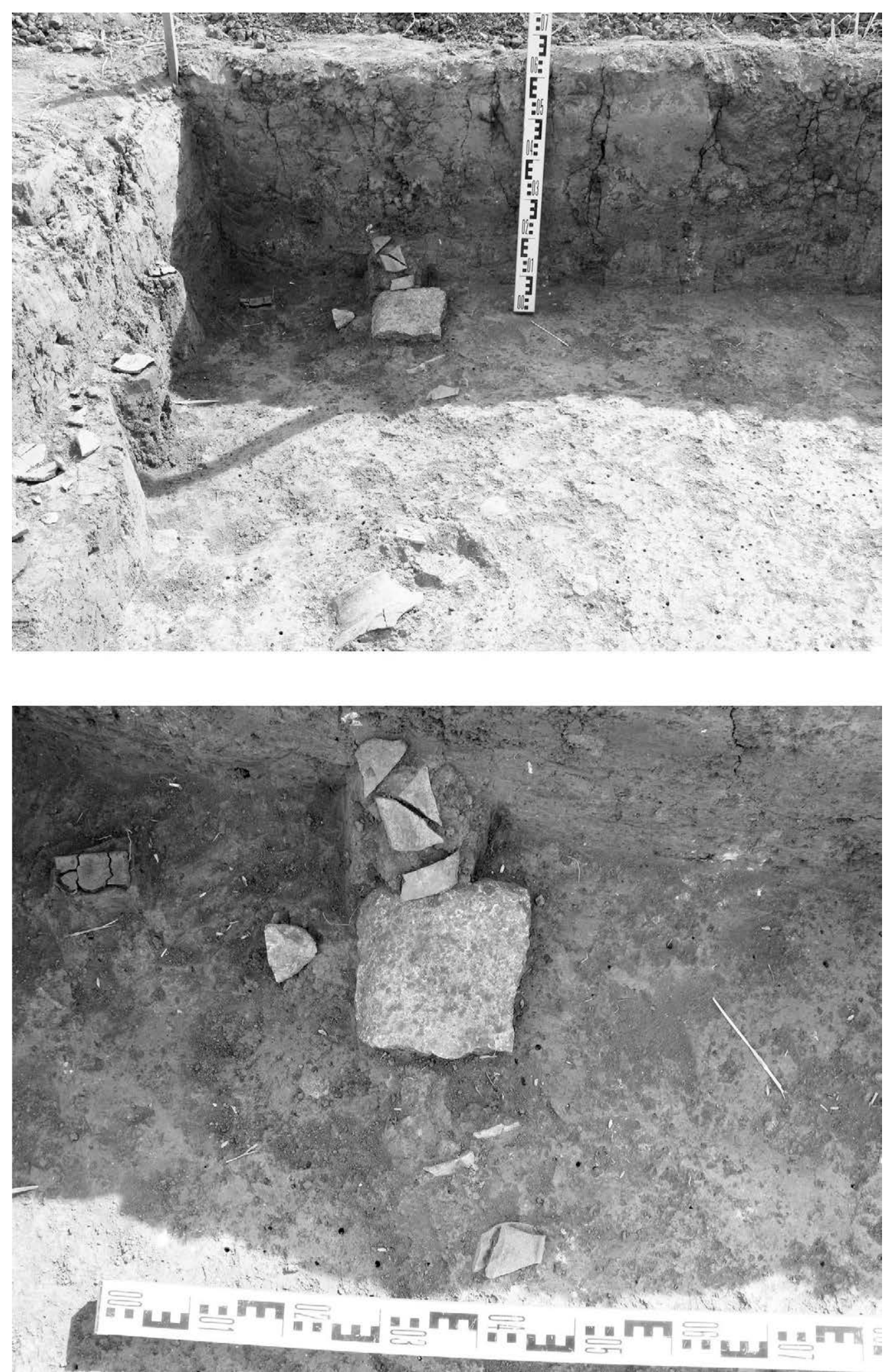

Рис. 13. Раскоп 2. 2012 г. Зачистка 4 штыка квадрата, вид с севера

1 - борт раскопа с зернотеркой, 2 - зернотерка 

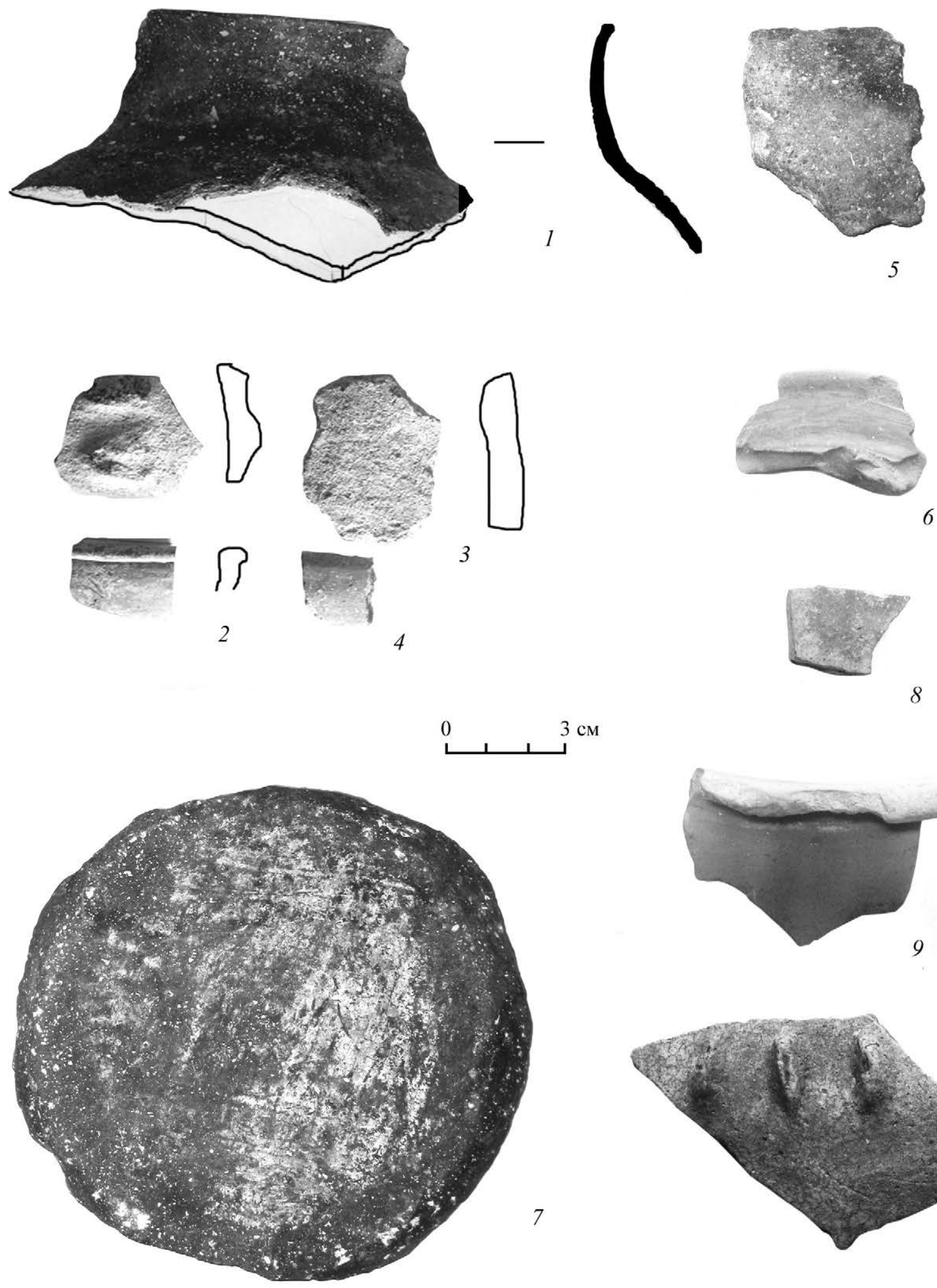

$3 \mathrm{~cm}$

7
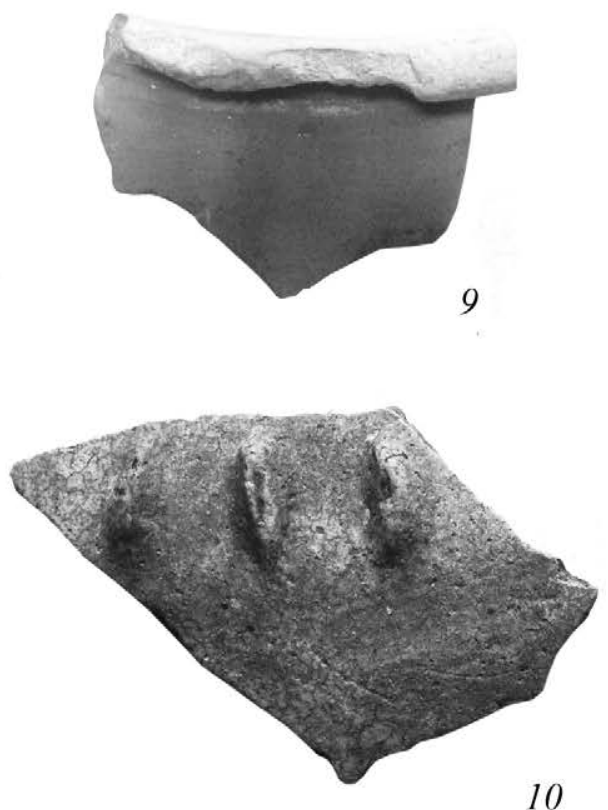

Рис. 14. Раскоп 2. 2012 г. Штык 4. Находки

1-9- штык 4, 10 - фрагмент керамики из скопления прирезки в восточном борту раскопа 

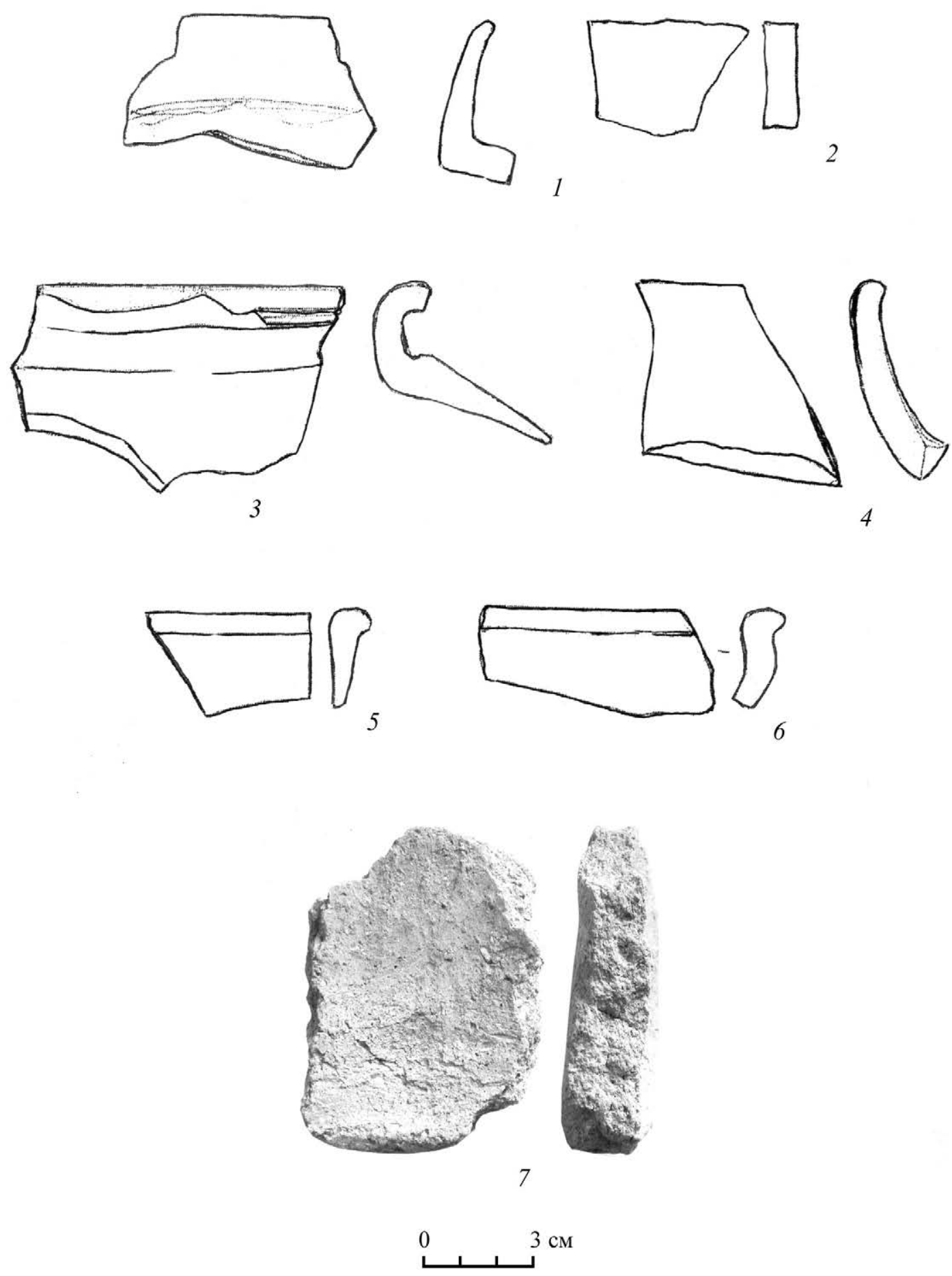

Рис. 15. Раскоп 2. 2012 г. Штык 4. Находки 

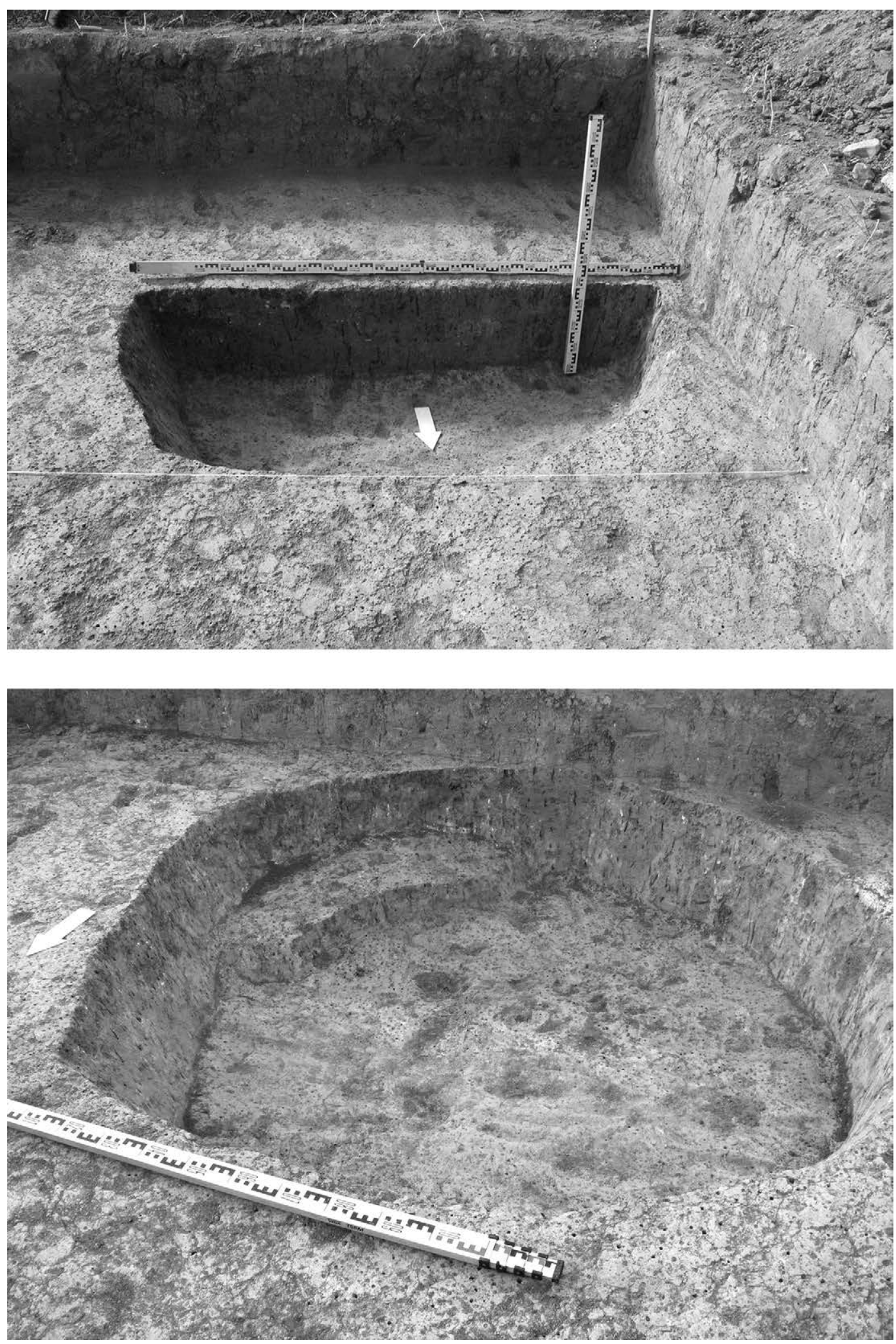

Рис. 16. Раскоп 2. 2012 г. Постройка 1 со ступенькой (яма 1)

1 - разрез ямы, 2 - вид на ступеньку 


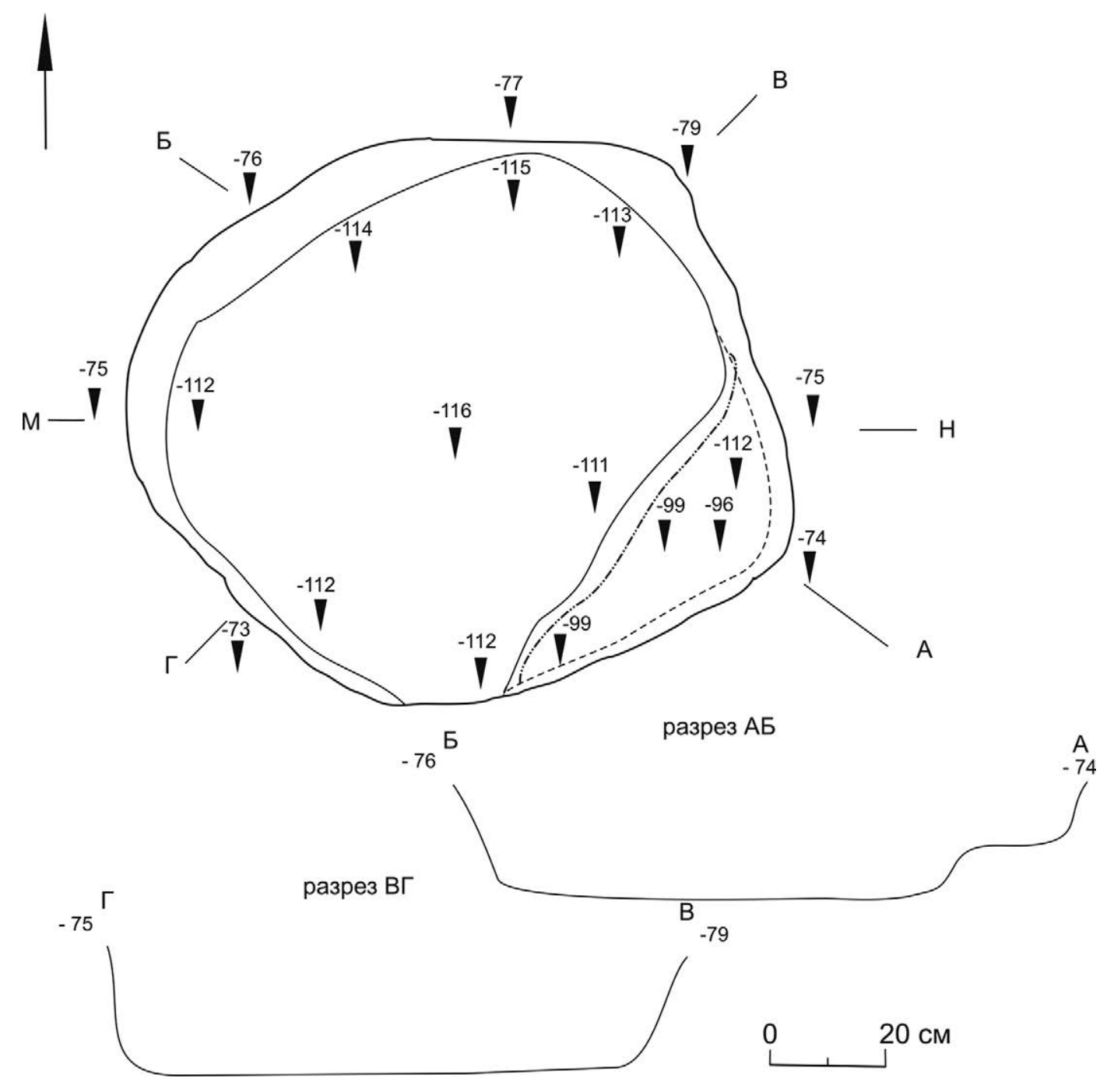

Рис. 17. Раскоп 2. 2012 г. Постройка 1. План и разрез 


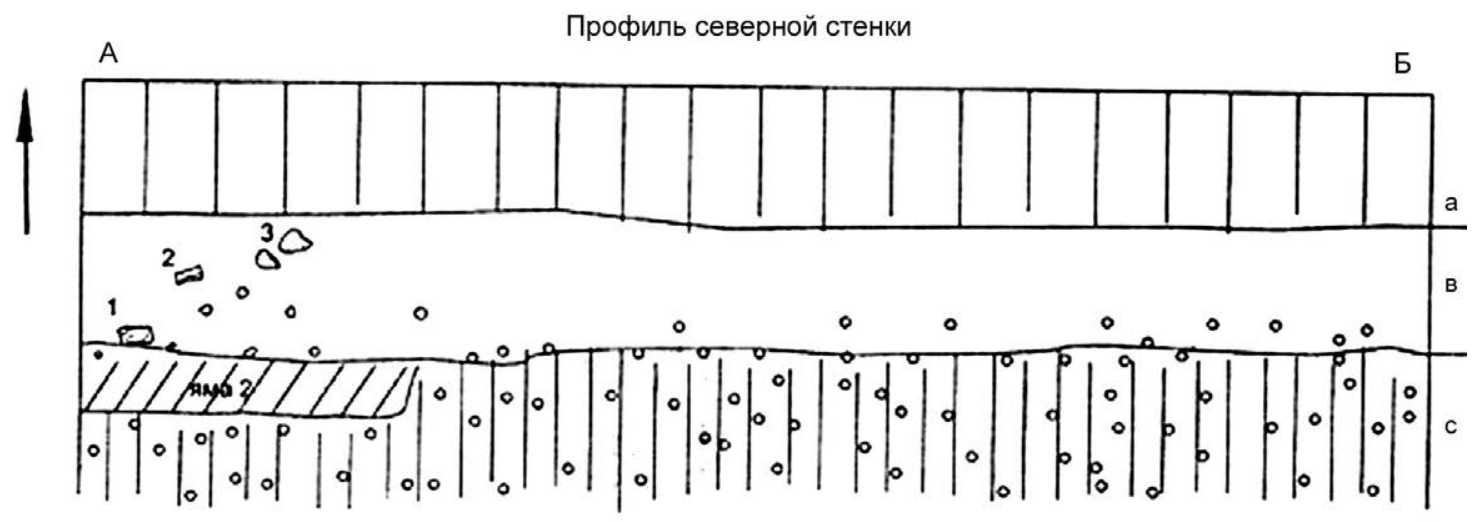

1 - зернотерка, 2 - фрагмент охристой керамики, 3 - кость животного

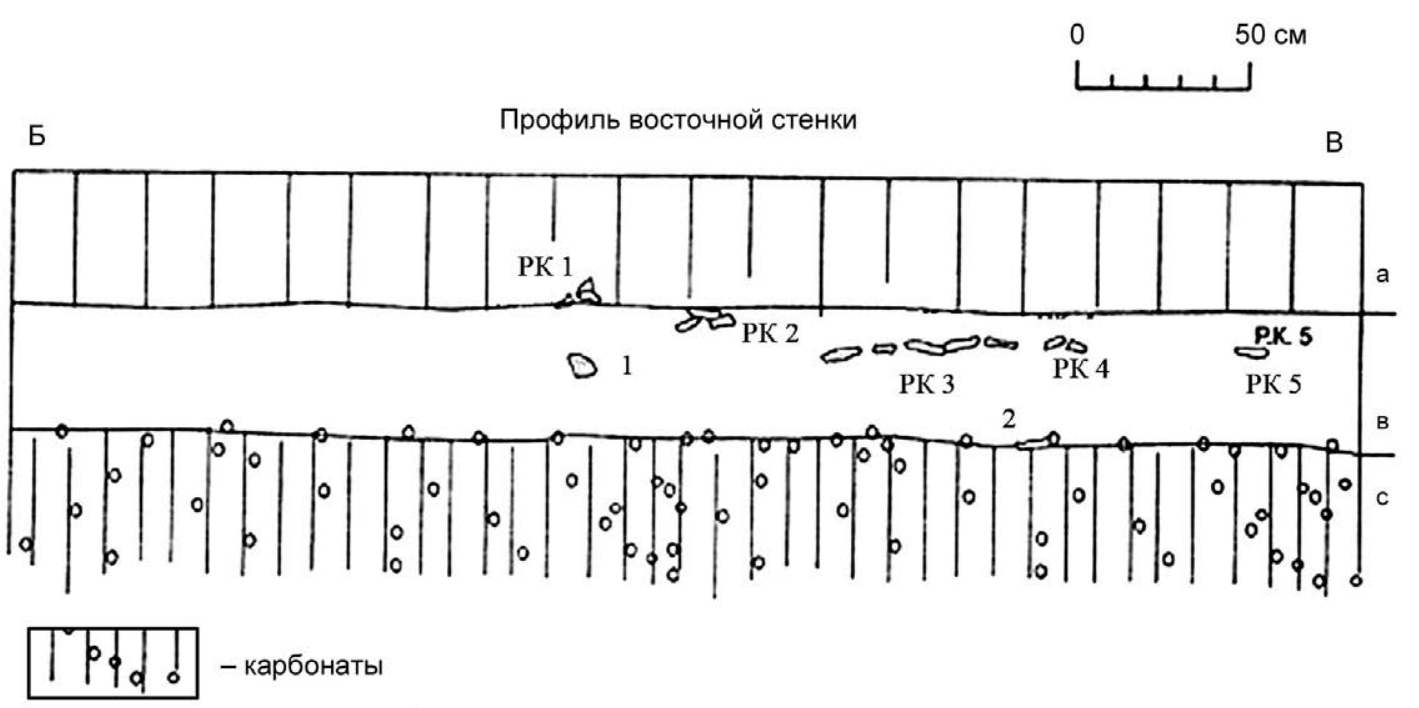

\section{Рис. 18. Раскоп 2. 2012 г. Профили северной и восточной стенок}

1 - раковина, 2 - фрагменты охристой керамики, а - слой пахоты, рыхлый черный на глубине до 60 см, в - надматериковый слой, серый плотный (культурный слой), с - материковый слой, (желтый суглинок с краплениями карбонатов) 
Профиль южной стенки

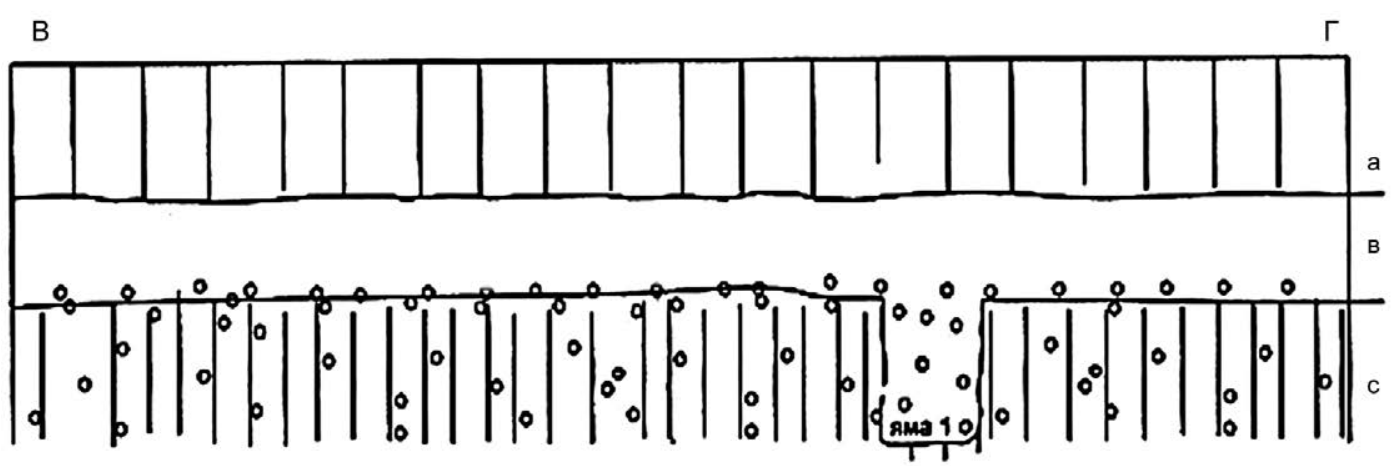

Профиль западной стенки
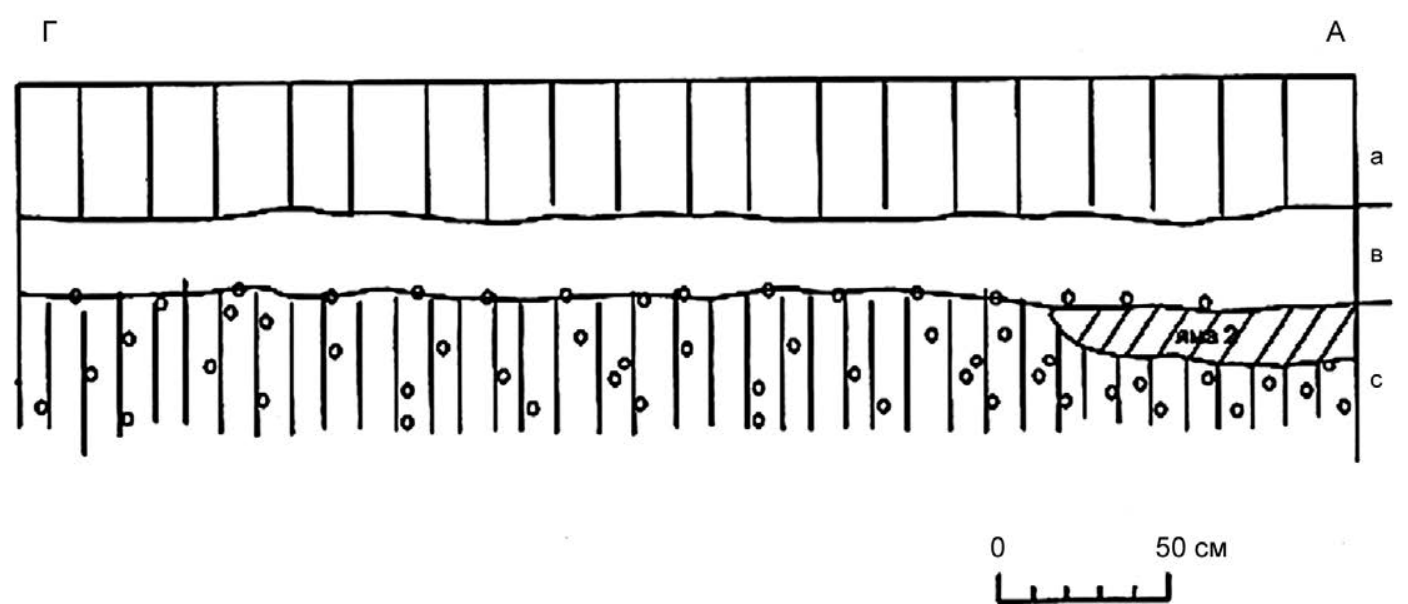

Рис. 19. Раскоп 2. 2012 г. Профили южной и западной стенок 


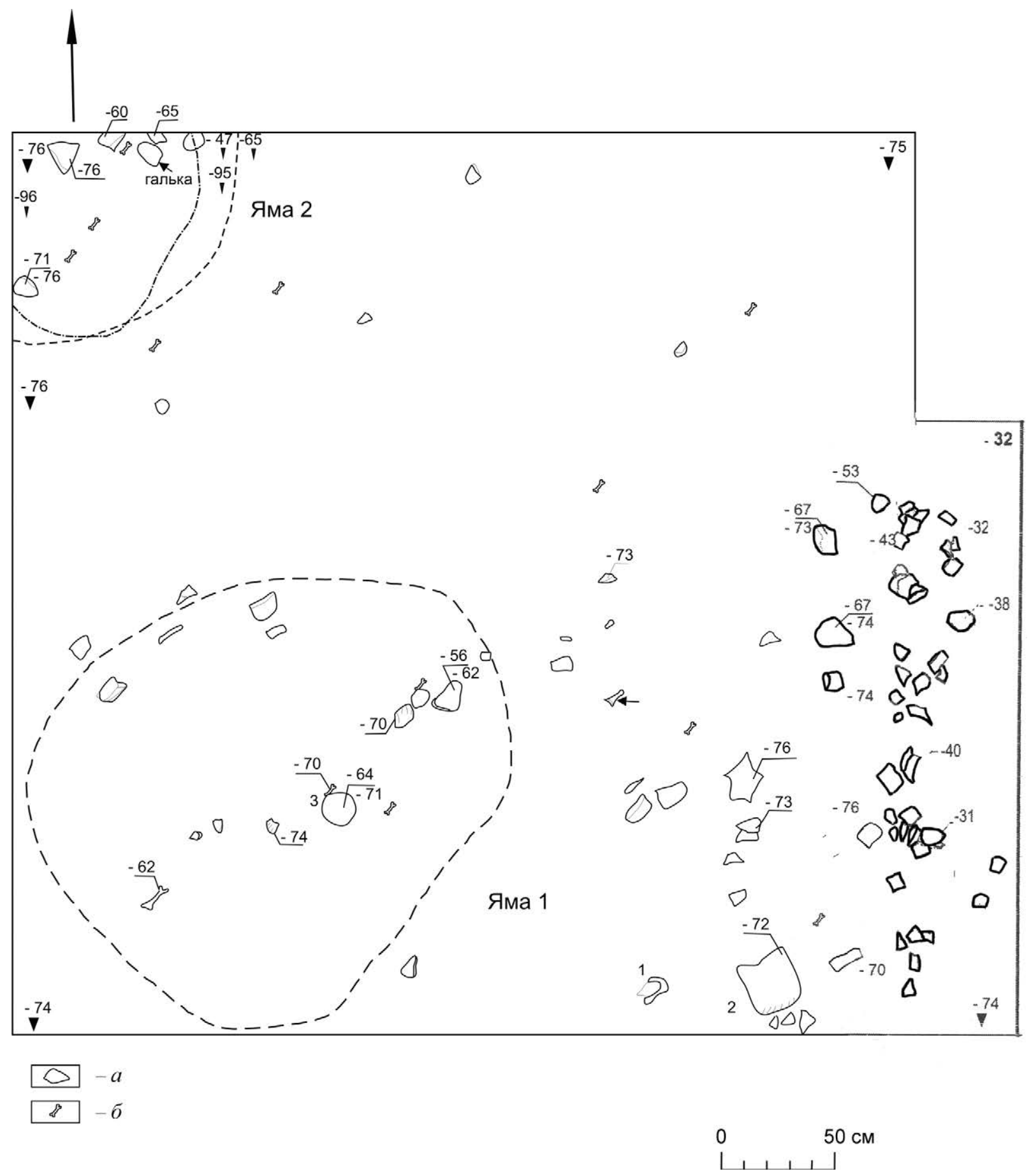

Рис. 20. Раскоп 2. 2012 г. Подчистка скоплений керамики у восточного борта раскопа

Условнъе обозначения:

$a$ - фрагмент керамики, б- кость животного. 1 - венчик охристый, 2 - зернотерка, 3 - дно сосуда 

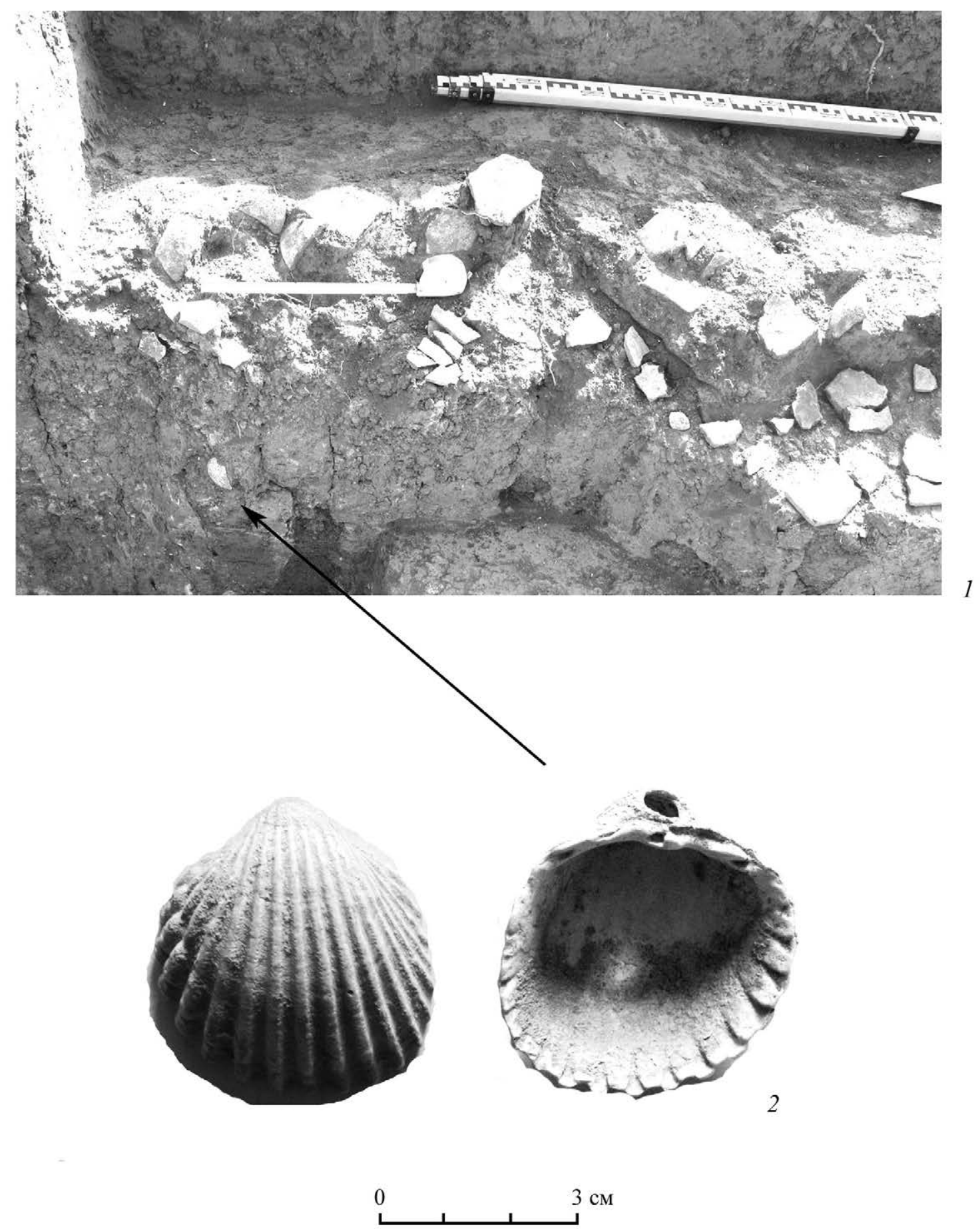

Рис. 21. Раскоп 2. 2012 г. Вид на подчистку у восточного борта раскопа

1 - вид на восточный борт раскопа и развал керамики, 2- находка раковины-подвески 

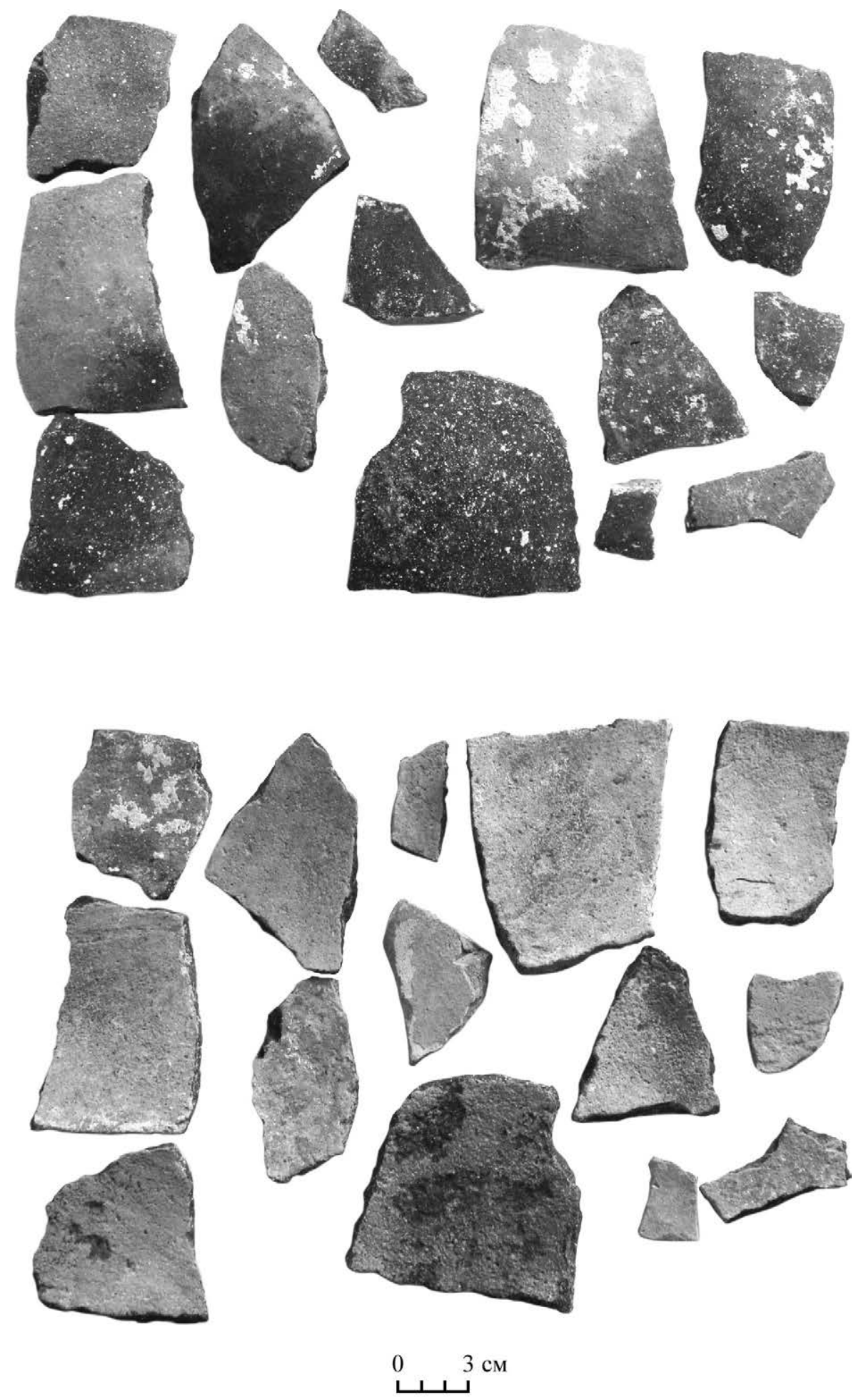

Рис. 22. Раскоп 2. 2012 г. Находки керамики из подчистки у восточной стенки раскопа 

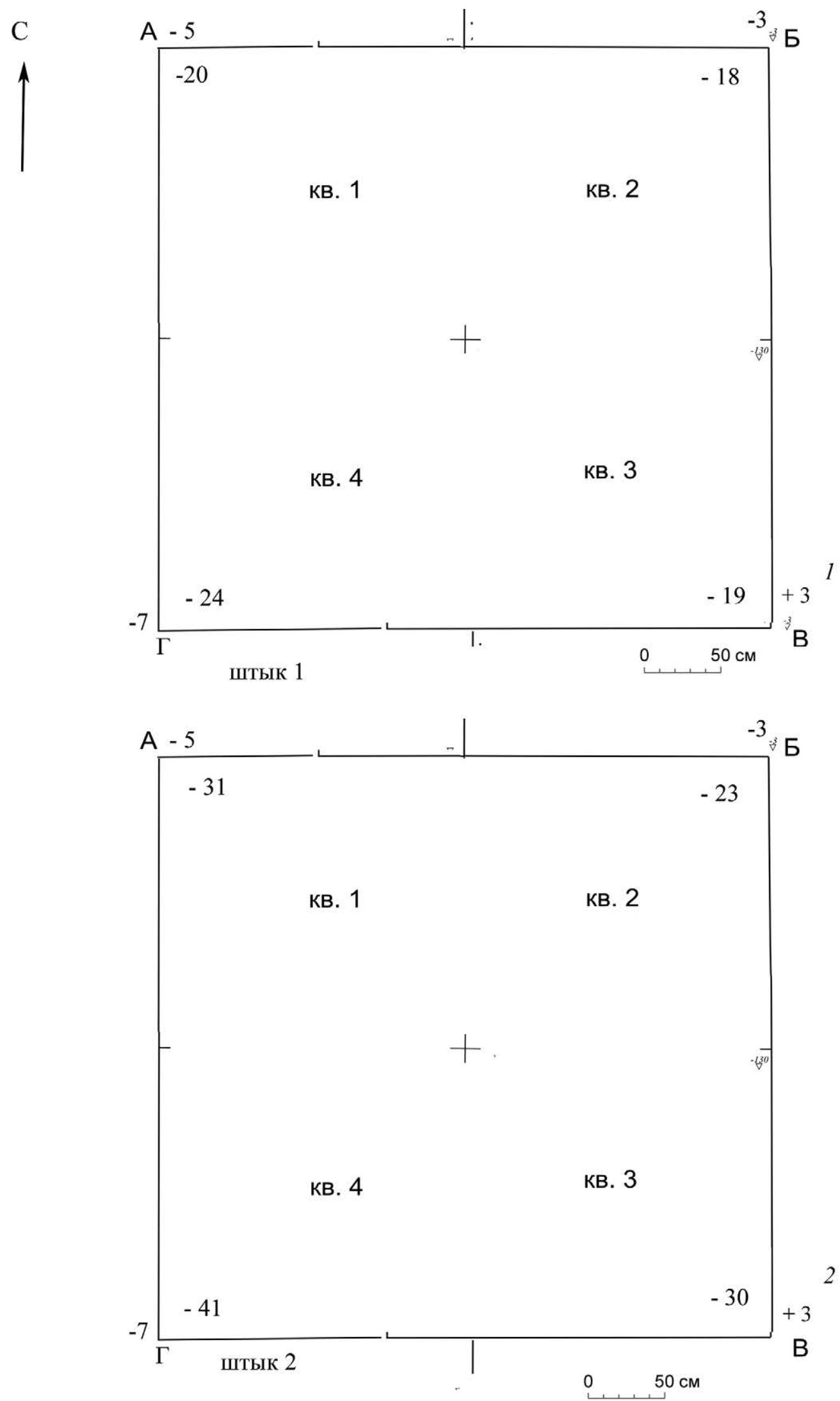

Рис. 23. Раскоп 3. 2013 г. 1 и 2 штыки раскопок

1- 1 штык, 2- 2 штык 


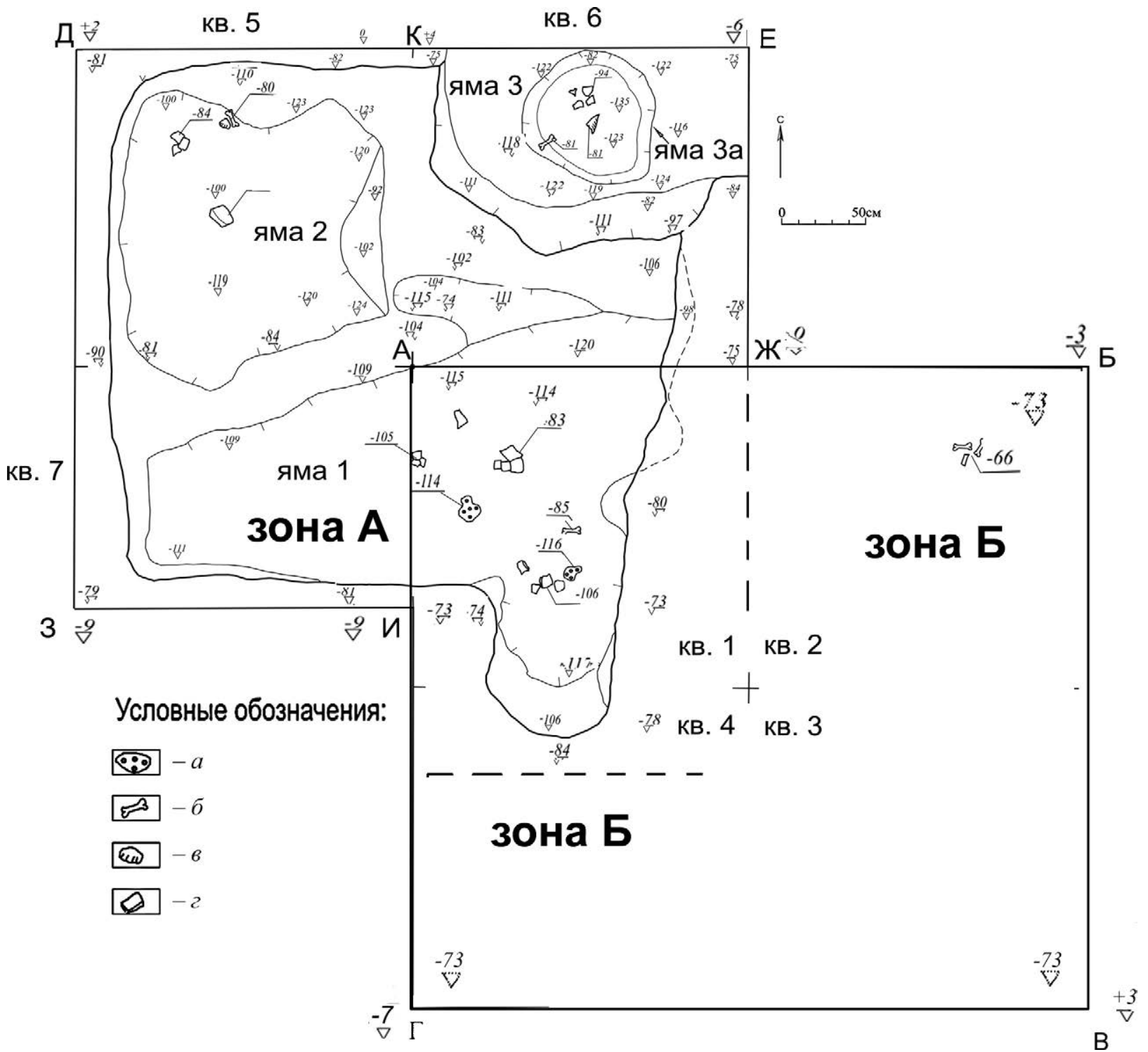

Рис. 24. Раскоп 3. 2013 г. Постройка 2. Расширение раскопа 3 и прирезка к нему зоны квадрата АБВГ Условнъе обозначения:

$a$ - органический тлен, б- кости животных, в- камни, г-керамика 


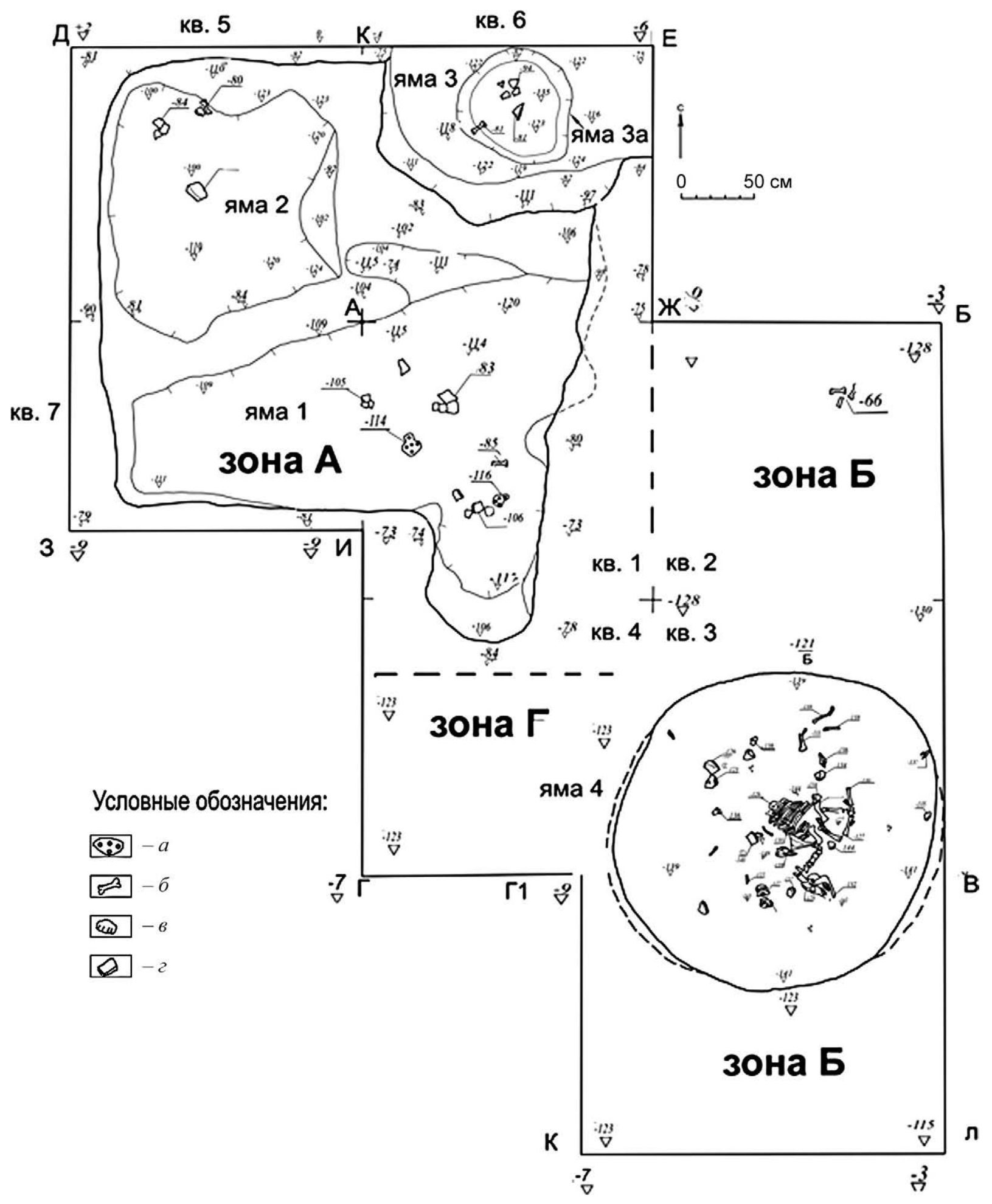

Рис. 25-1. Раскоп 3. 2013 г. Постройка 2. Работы в зоне Б и прирезка для раскопок ямы 4 Условные обозначения:

$a$ - органический тлен, б- кости животных, в-камни, г-керамика 

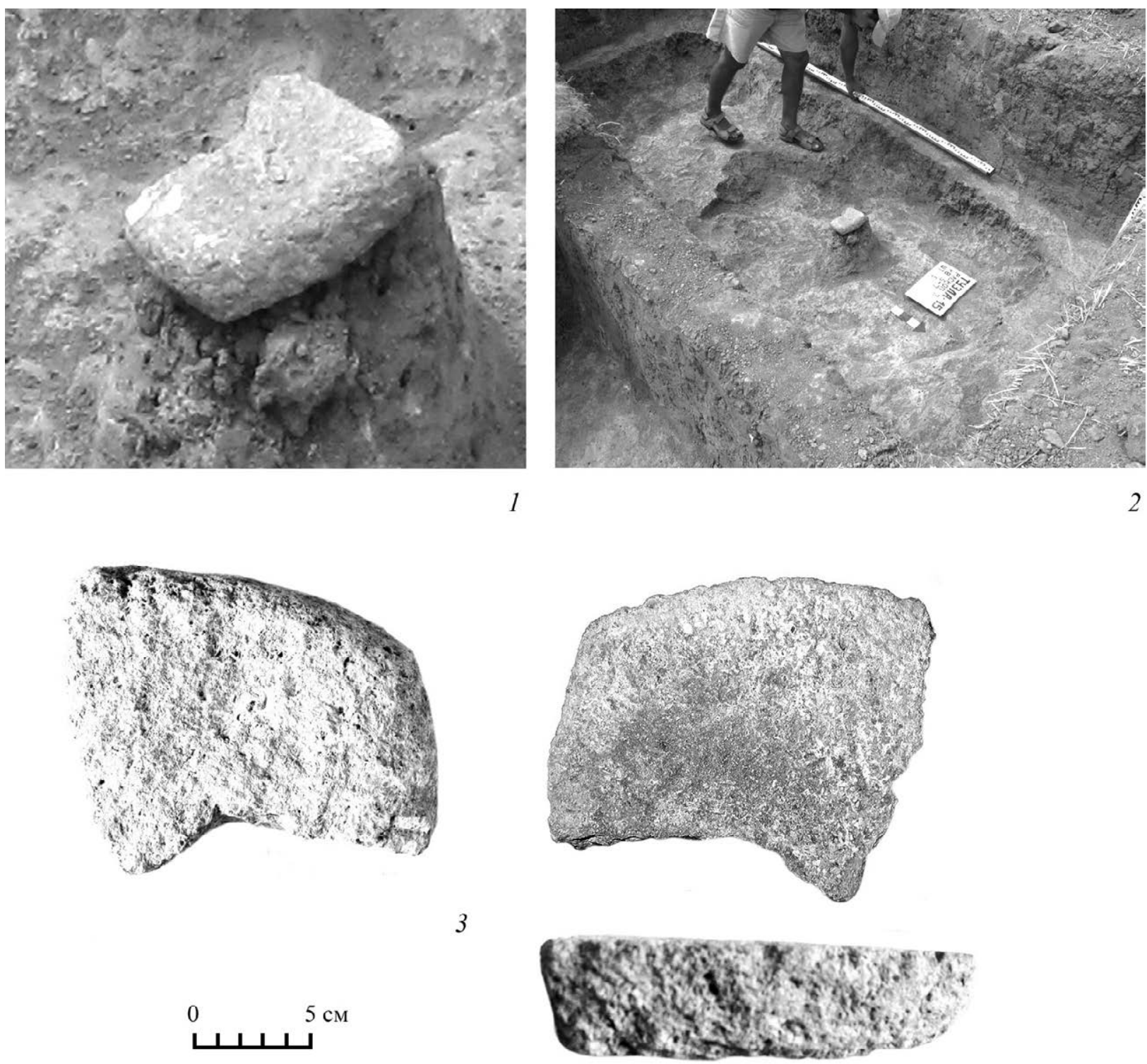

3

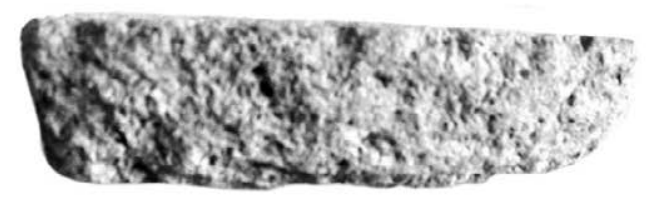

Рис. 25-2. Раскоп 3. 2013 г. Постройка 2. Зернотерка

1 - зернотерка лежит вниз рабочей частью, 2- зернотерка в зоне постройки, 3- зернотерка, общий вид 

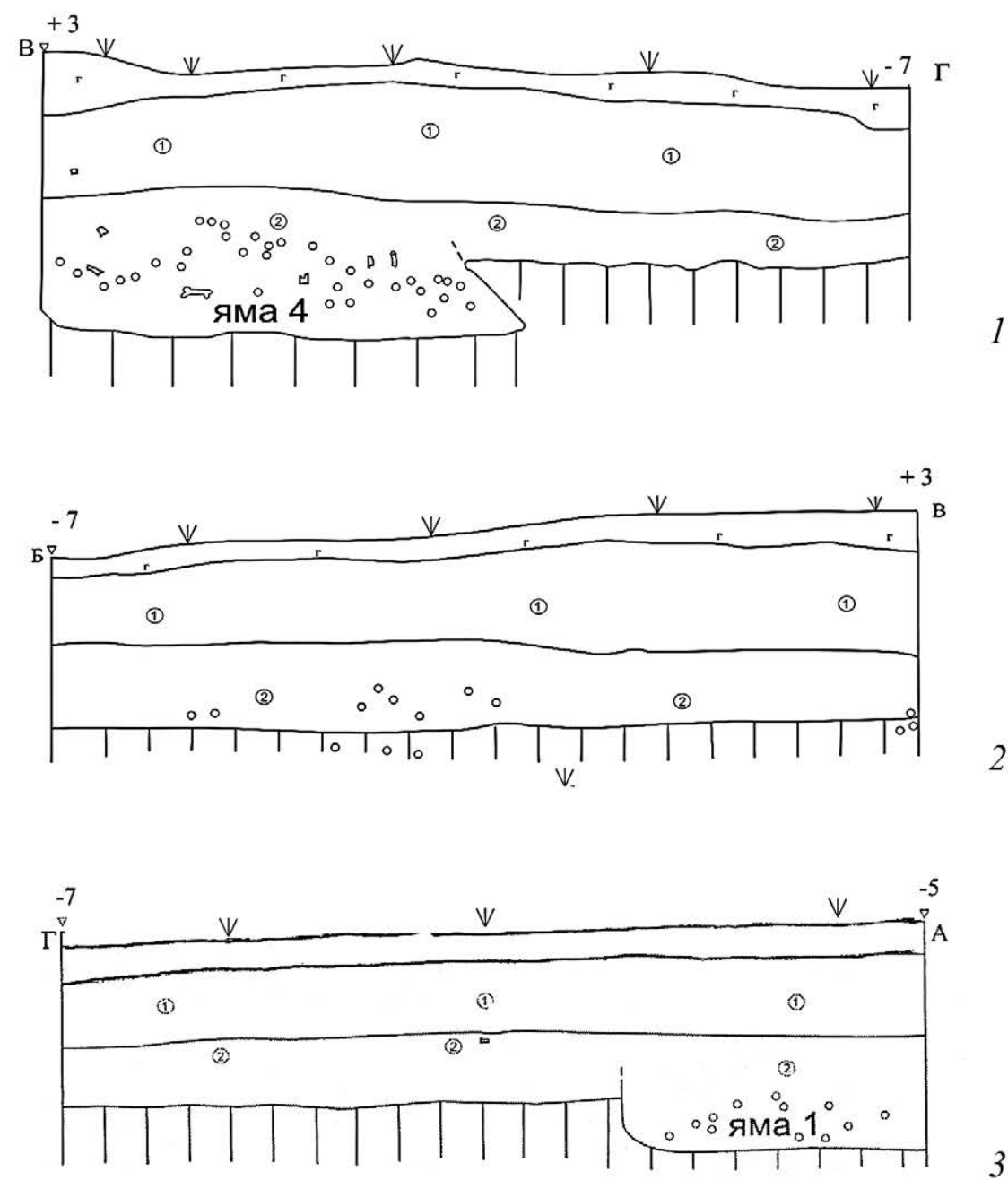

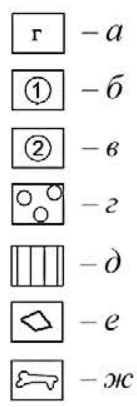
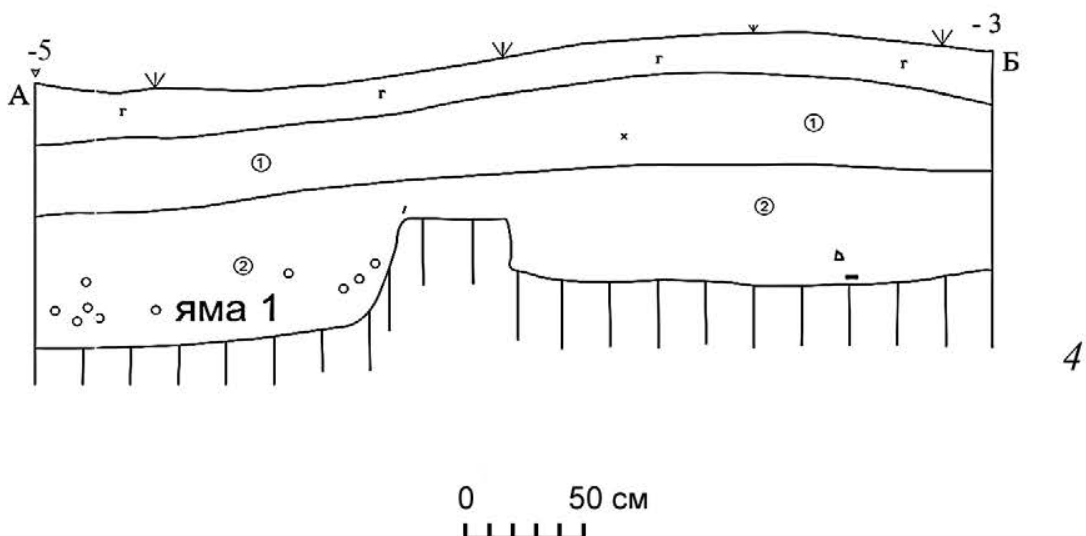

Рис. 26. Раскоп 3. 2013 г. Профили раскопа 3

1 - профиль В-Г, 2 - профиль Б-В, 3 - профиль Г-А, 4- профиль А-Б

Условные обозначения:

$a$ - гумус, б- пахотный слой, $в$ - культурный слой, г-карбонаты, $\partial$ - материк, $e$ - керамика, ж-кость 
Восточный борт кв. 6, профиль Е-Ж
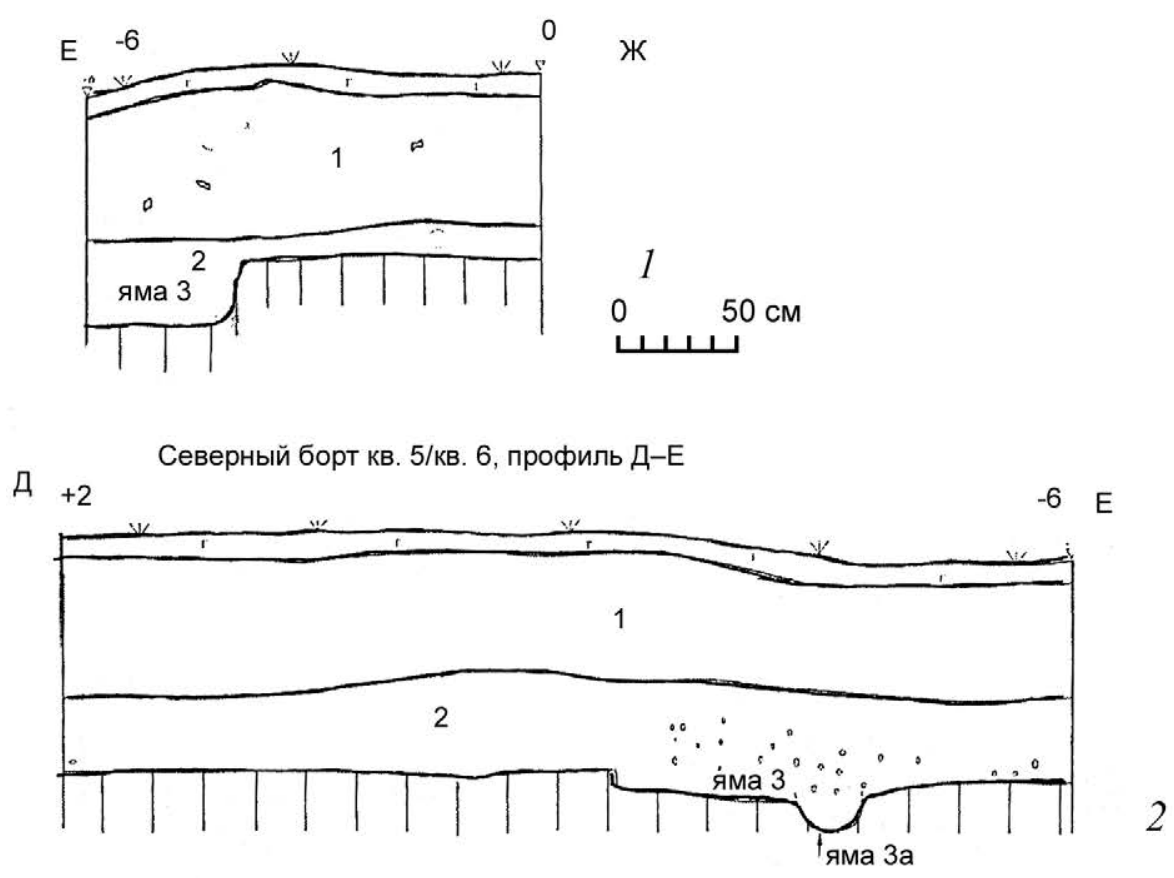

Южный борт кв. 7, профиль И-3
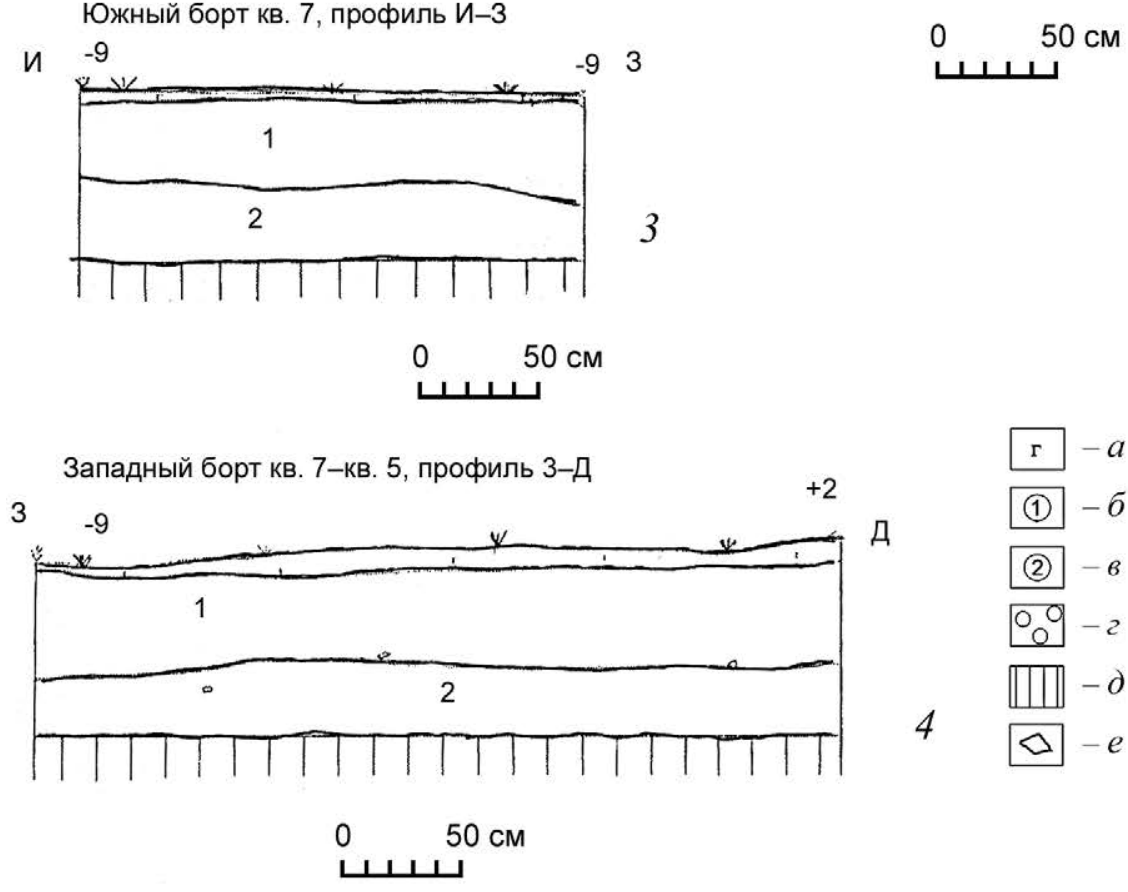

Рис. 27. Раскоп 3. 2013 г. Разрезы раскопа 3.

1 - восточный борт кв. 6, профиль Е-Ж, 2- северный борт кв. 5/кв. 6, профиль Д-Е, 3- южный борт кв. 7, профиль И-3, 4- западный борт кв. 7 профиль 3-Д

Условные обозначения:

$a$ - гумус, б- пахотный слой, в-культурный слой, г-карбонаты, $\partial$ - материк, $e$ - керамика 

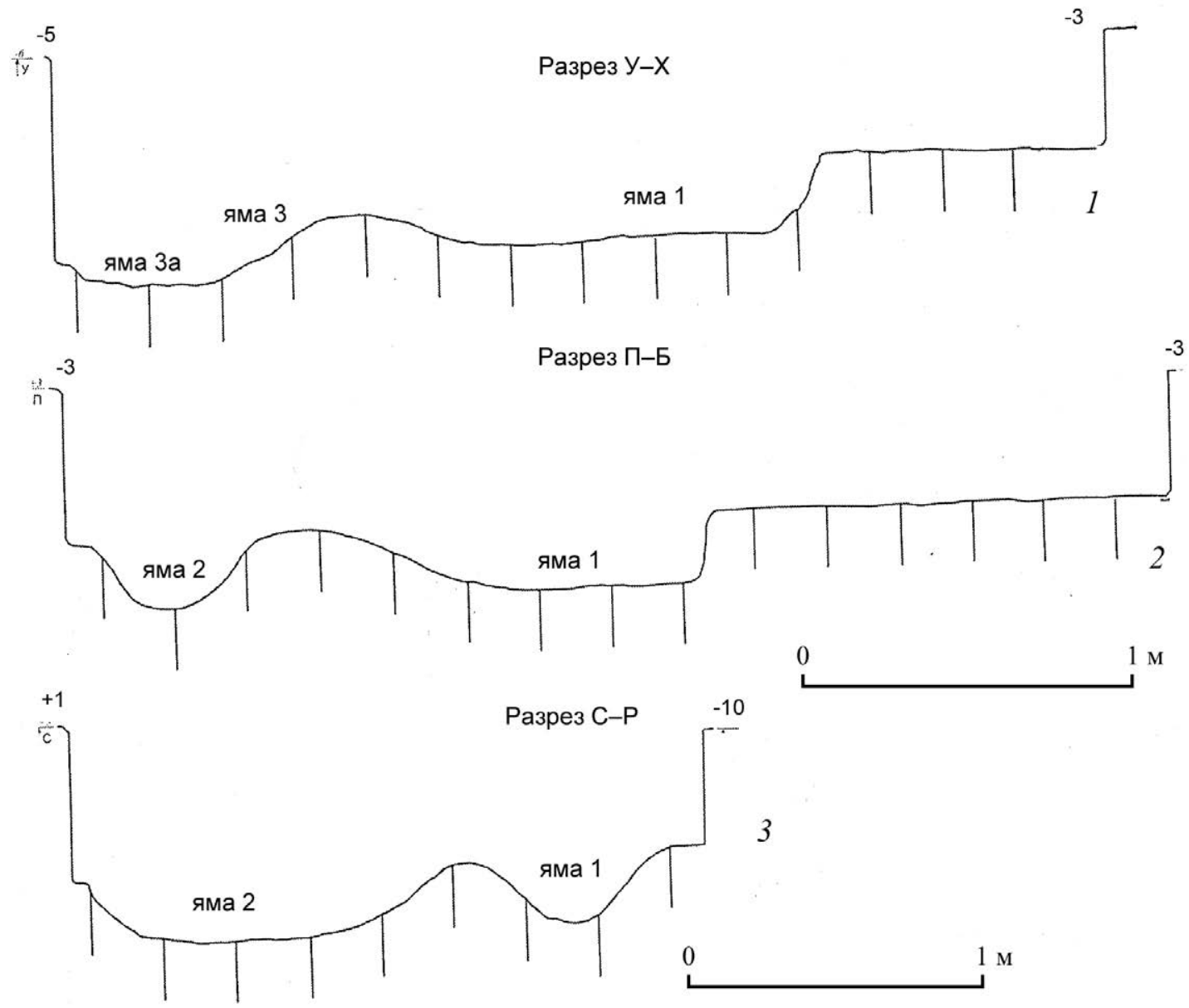

Рис. 28. Разрезы раскопа 3. 2013 г.

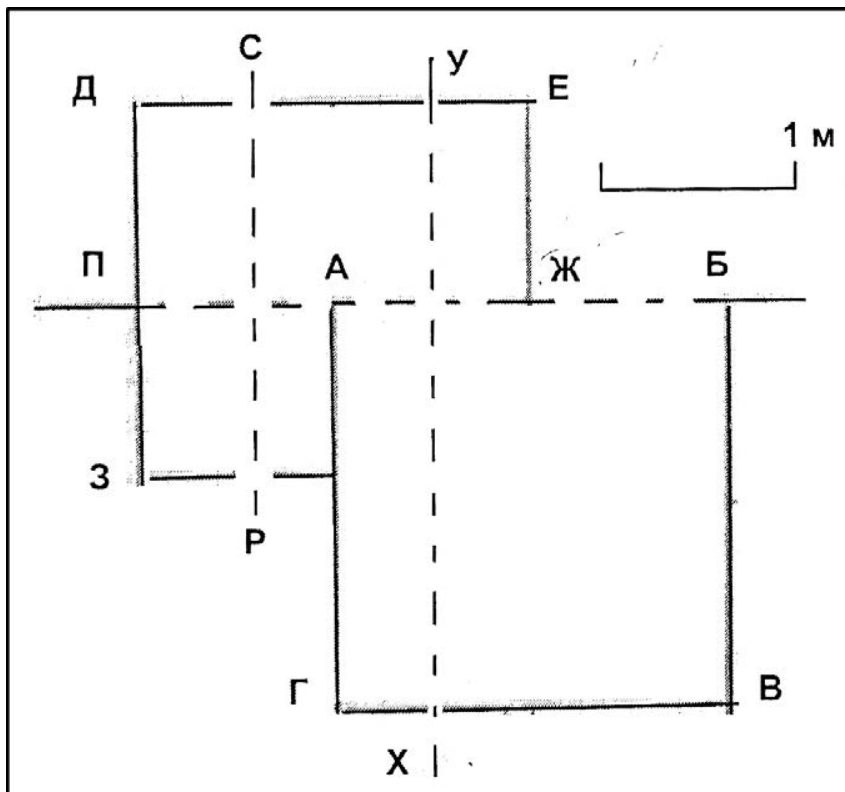

Рис. 29. Схема разрезов и квадратов раскопа 3. 2013 г. 

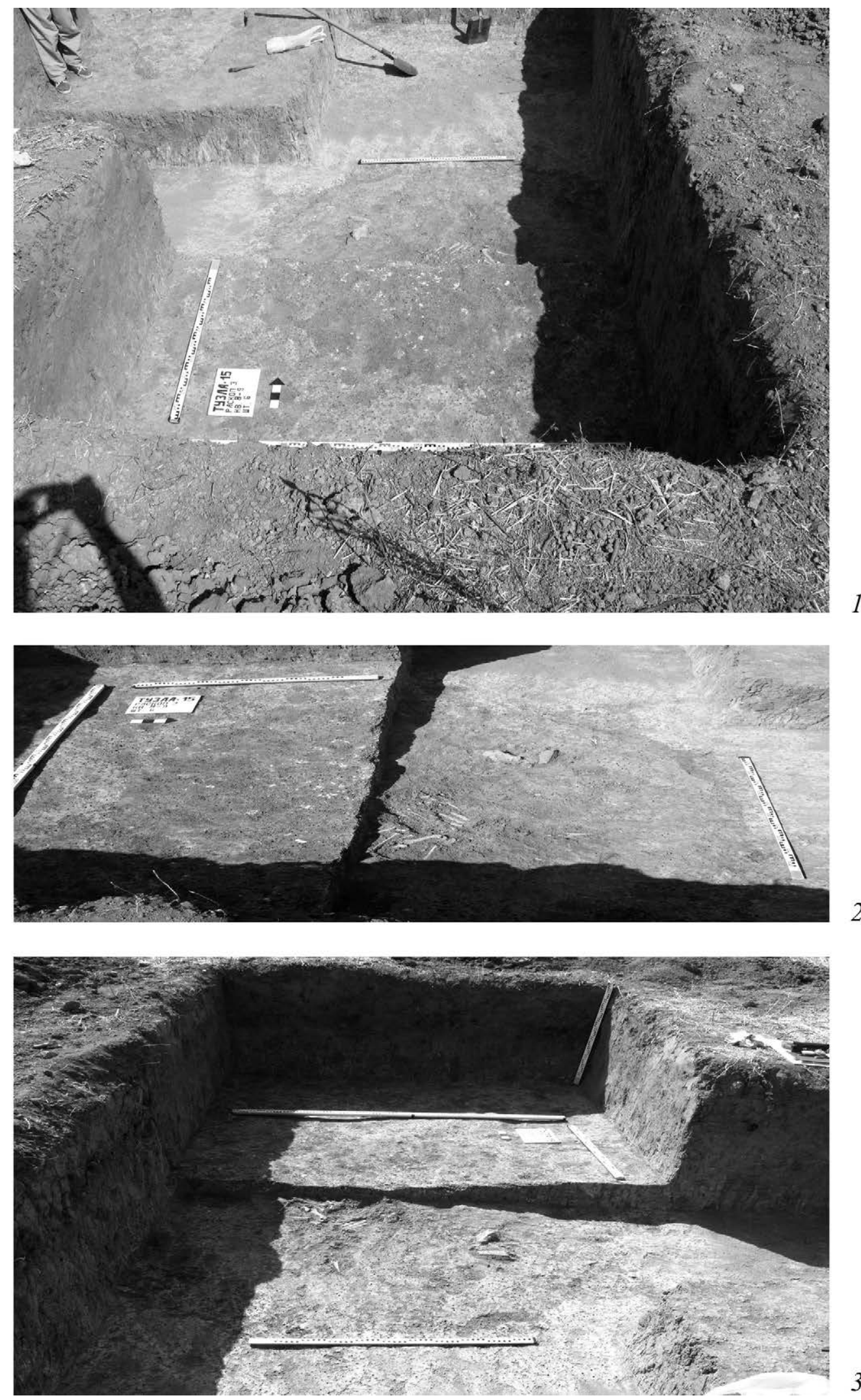

Рис. 30. Раскоп 3. 2013 г. Пятно ямы 4

1-3- фрагменты расчистки и работ 

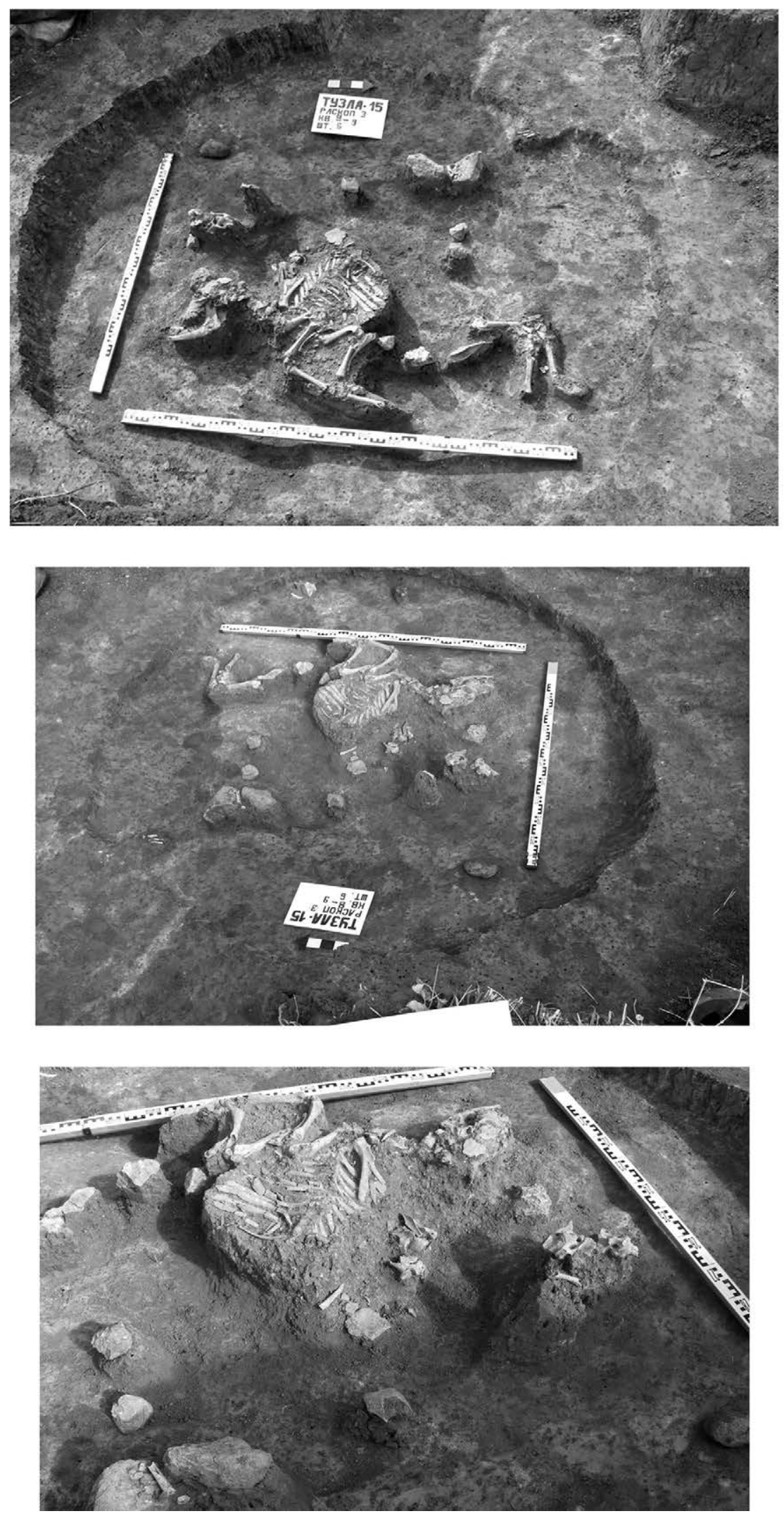

Рис. 31. Раскоп 3. 2013 г. Яма 4

1 - вид с востока, 2 - вид с запада, 3 - вид с северо-запада 


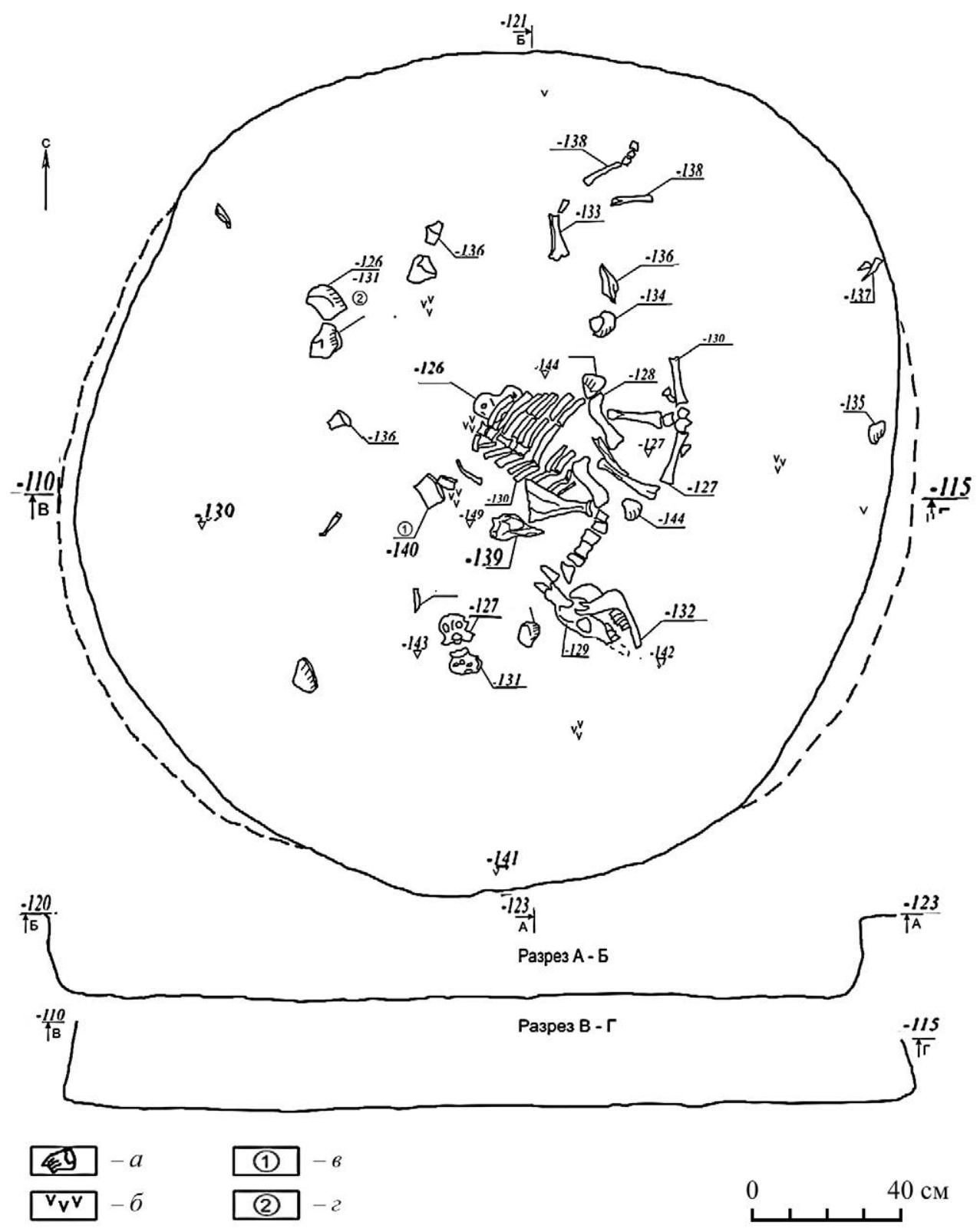

Рис. 32. Раскоп 3. 2013 г. Яма 4. Погребение теленка (чертеж)

Условные обозначения:

$a$ - камни, $\sigma$ - уголь, 8 - фрагмент лепной керамики, 2 - фрагмент зернотерки 


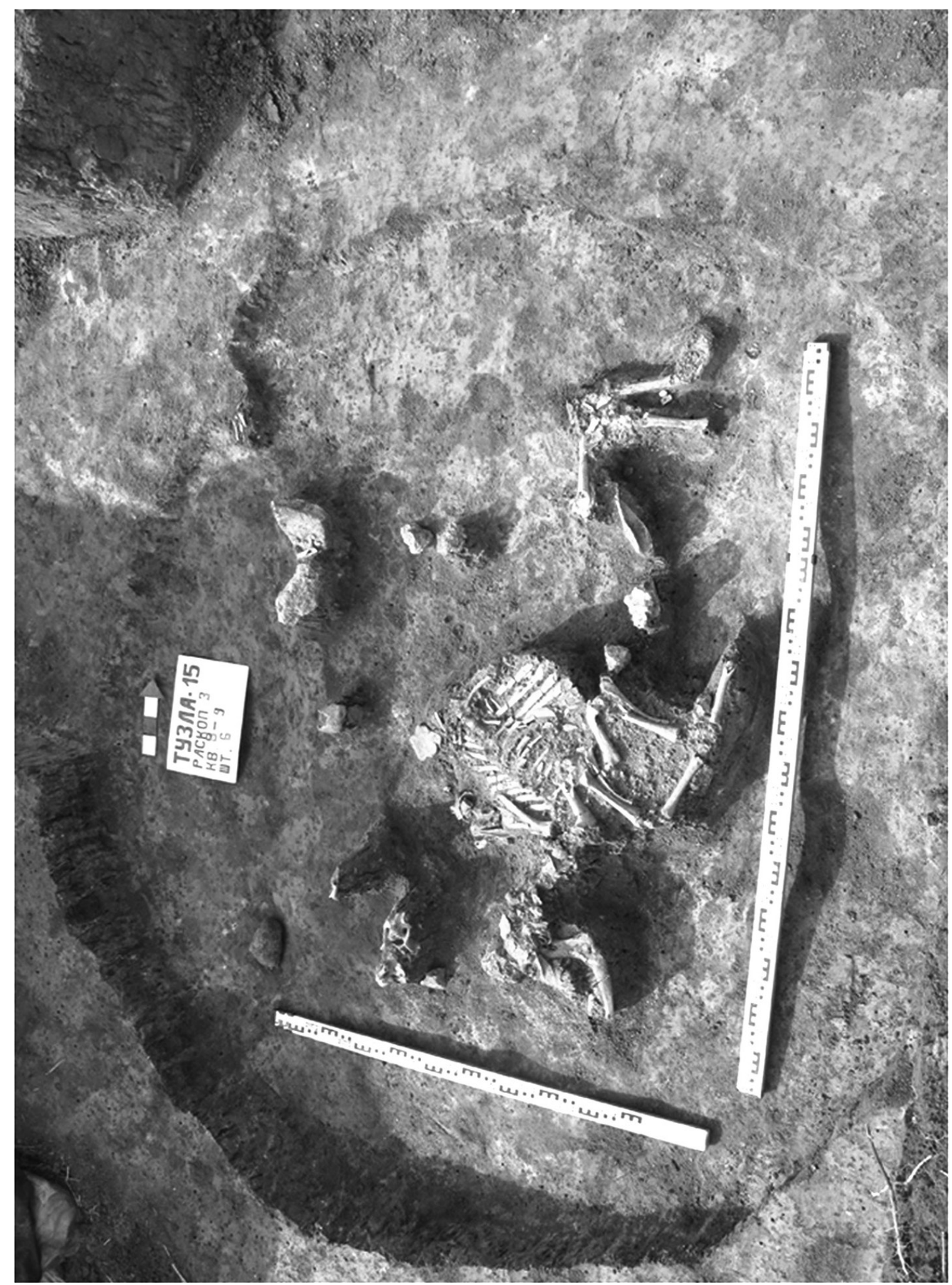




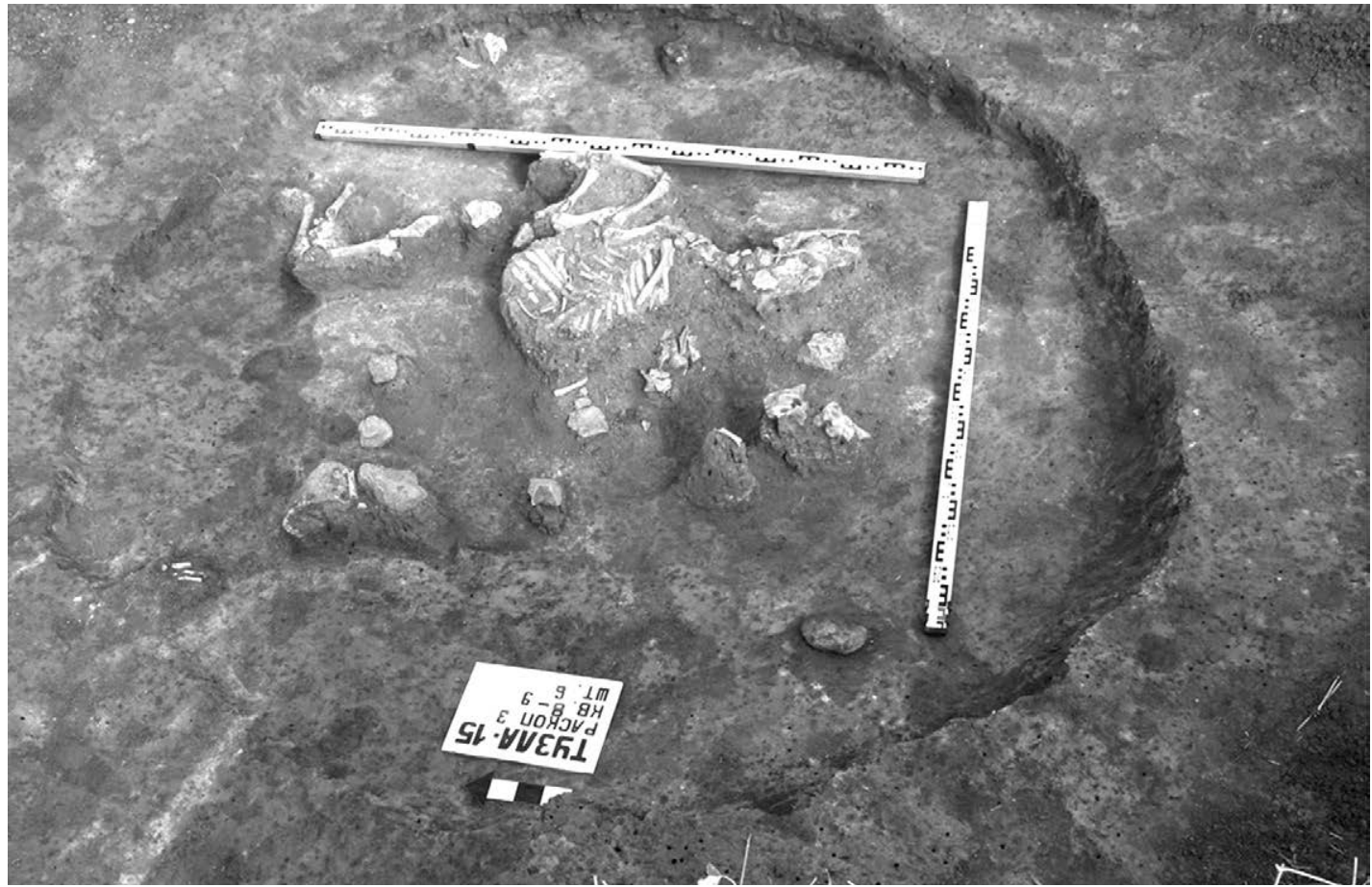

Рис. 34. Раскоп 3. 2013 г. Погребение теленка (крупный палн)

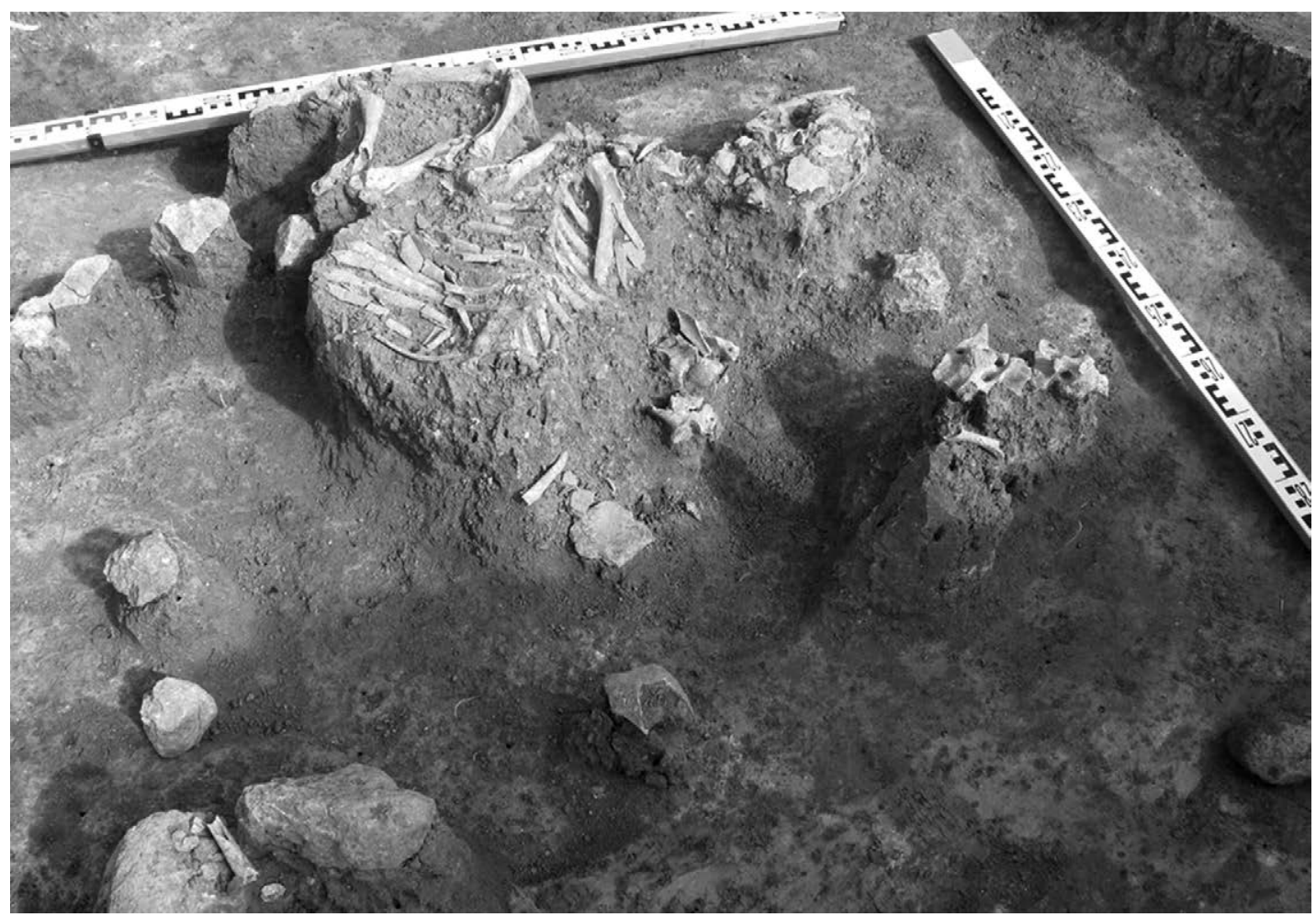

Рис. 35. Раскоп 3. 2013 г. Погребение теленка (крупный план) 

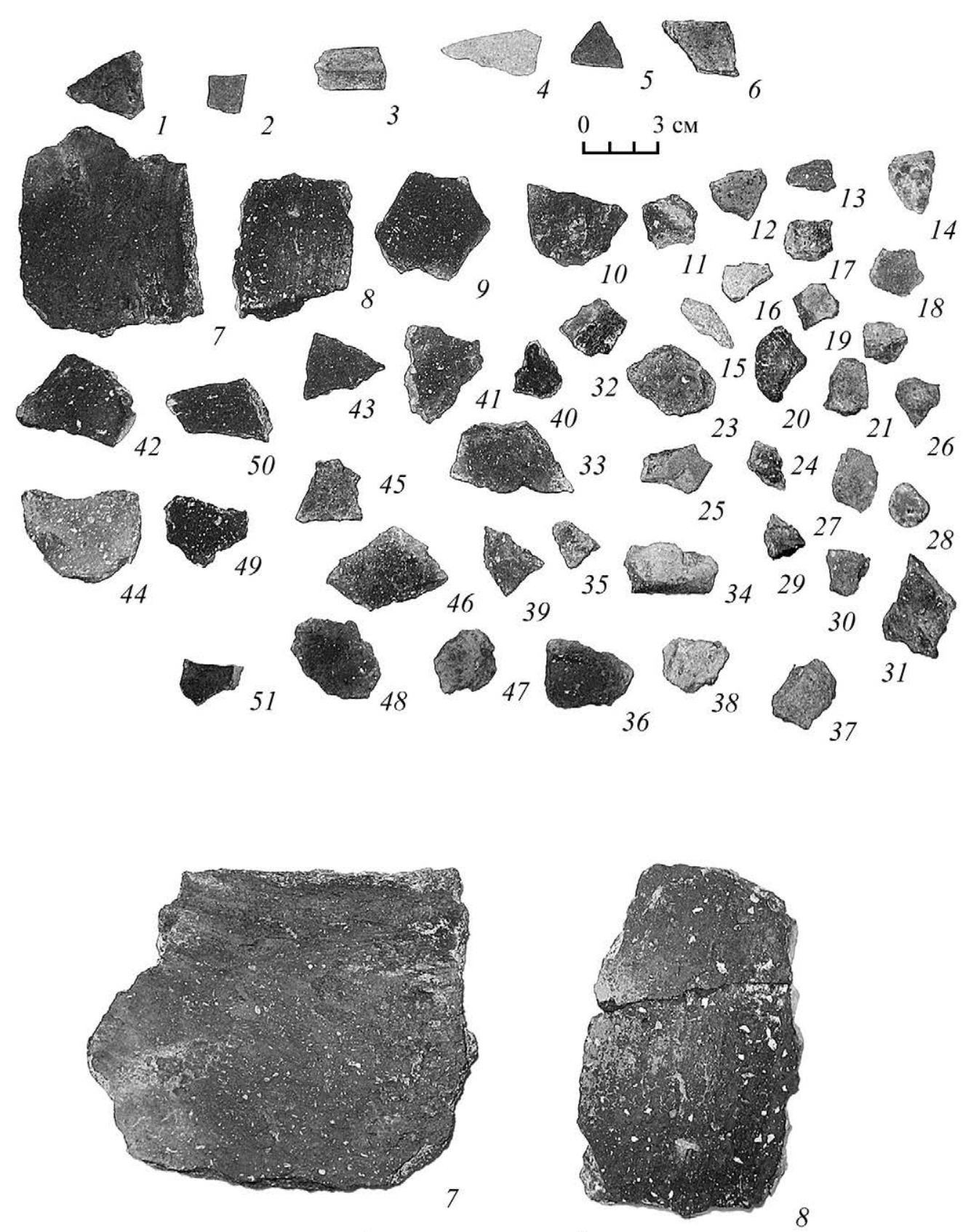

Рис. 36. Раскоп 3. 2013 г. Находки в яме 4 

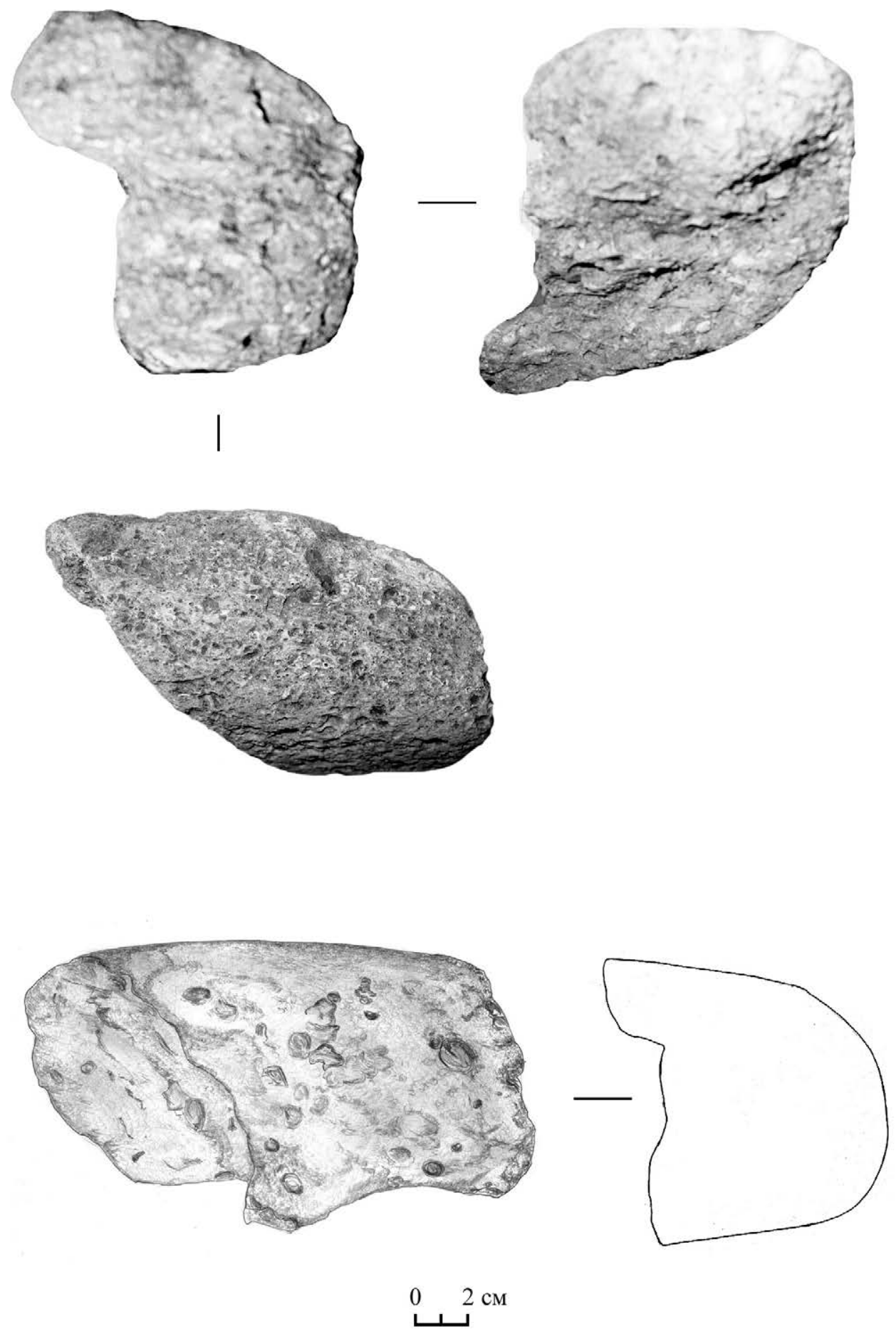

Рис. 37. Раскоп 3. 2013 г. Обломок зернотерки из ямы 4 


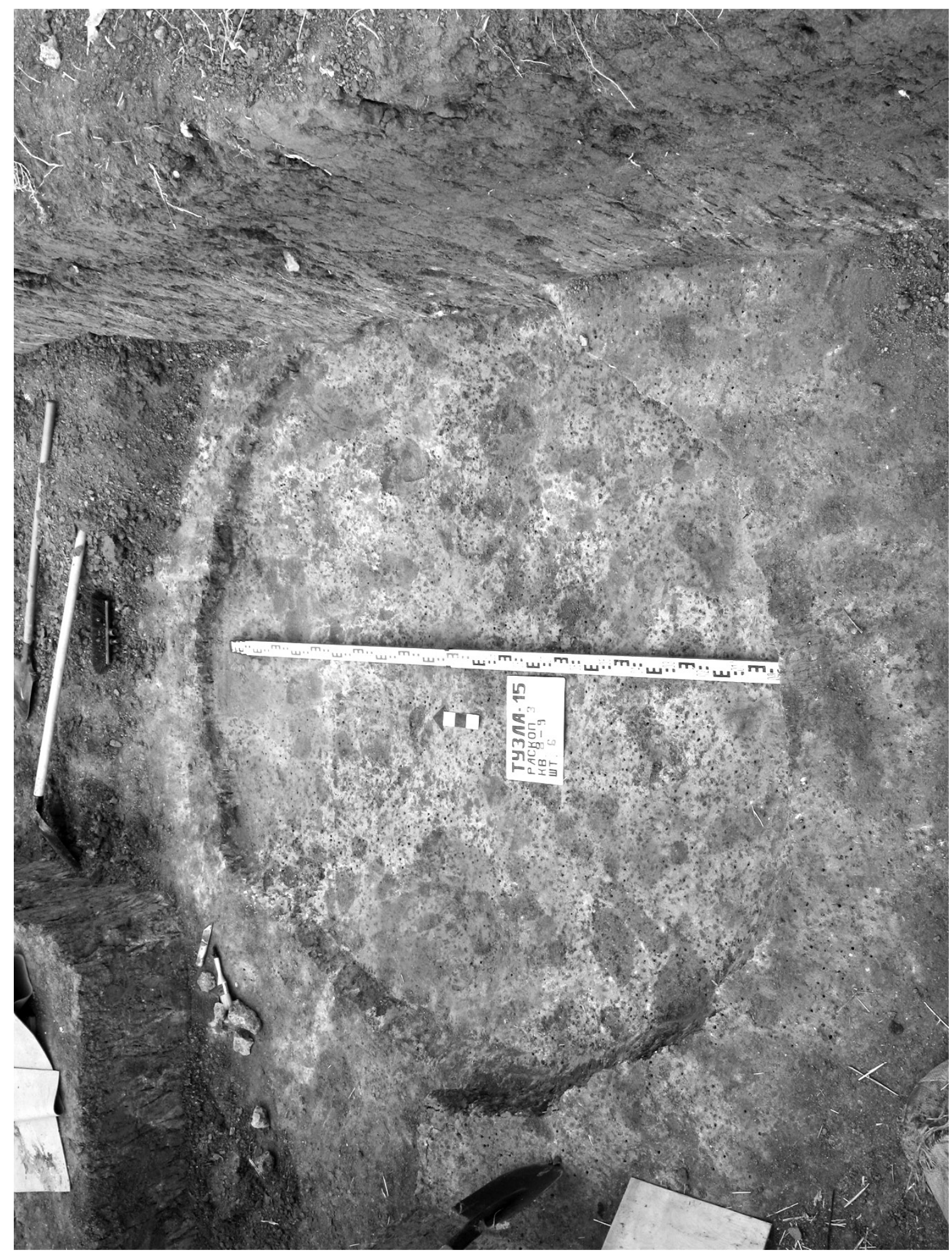



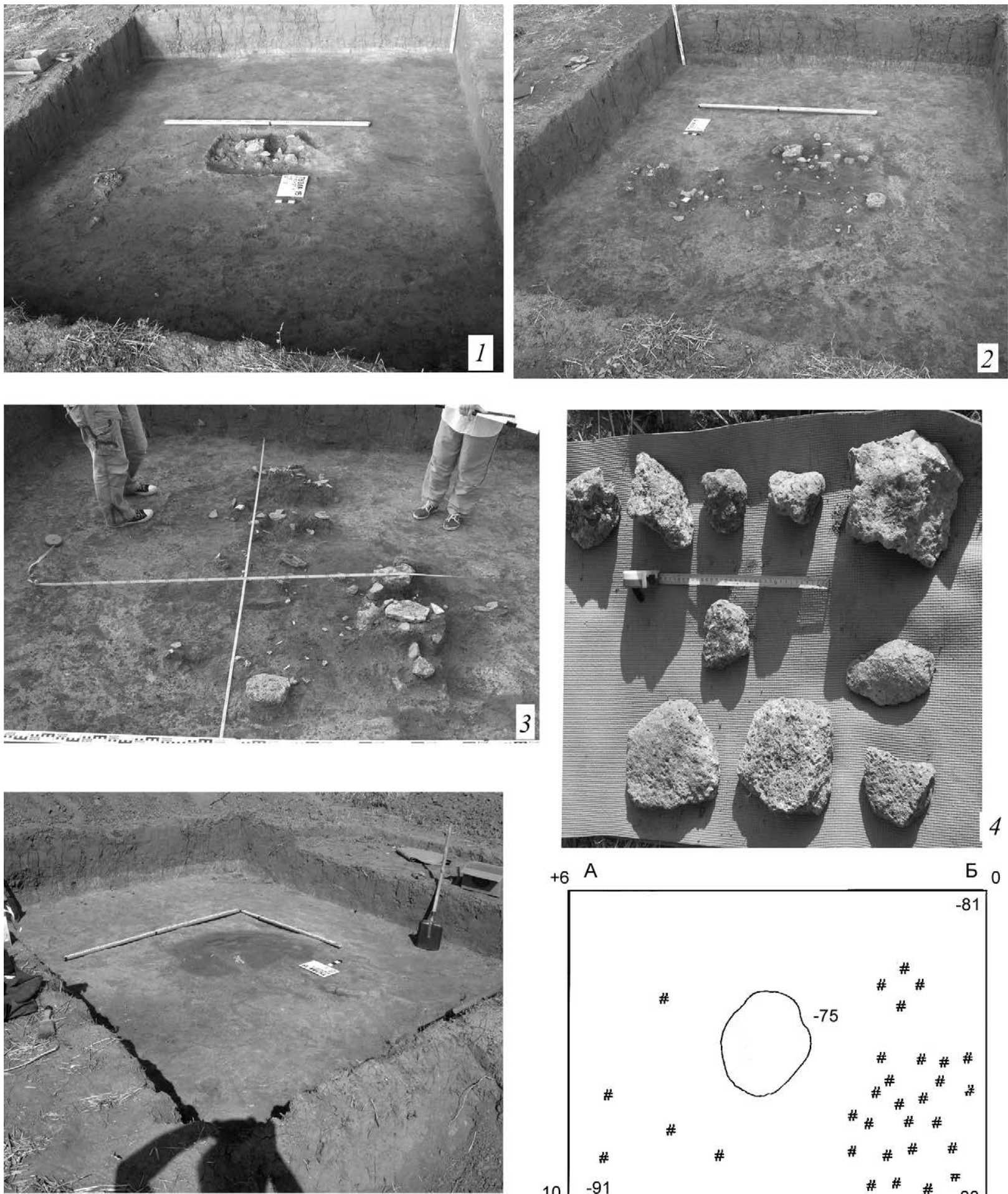

$+6 \mathrm{~A}$

Б 0

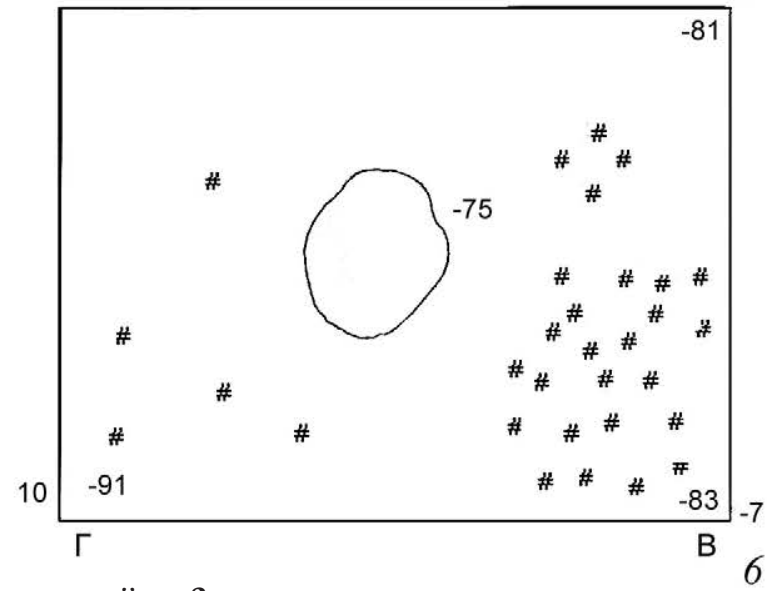

Рис. 39. Раскоп 4. 2013 г. Этапы работ по раскопкам постройки 3

1 - Вид с востока. Оконтурены верхние камни. Глубина -58, -64 см.

2 - Расчистка скопления камней на глубине -73 - -74 см. Вид с востока

3 - Расчистка камней на глубине -73, -74 см Вид с севера

4 - Камни (обломки зернотерок) из скопления

5 - Появление четкого пятна ямы 1 под скоплением камней. Глубина -75 см.

6- Зачистка квадрата после обнаружения пятна и условные знаки косой решеткой находок керамики 

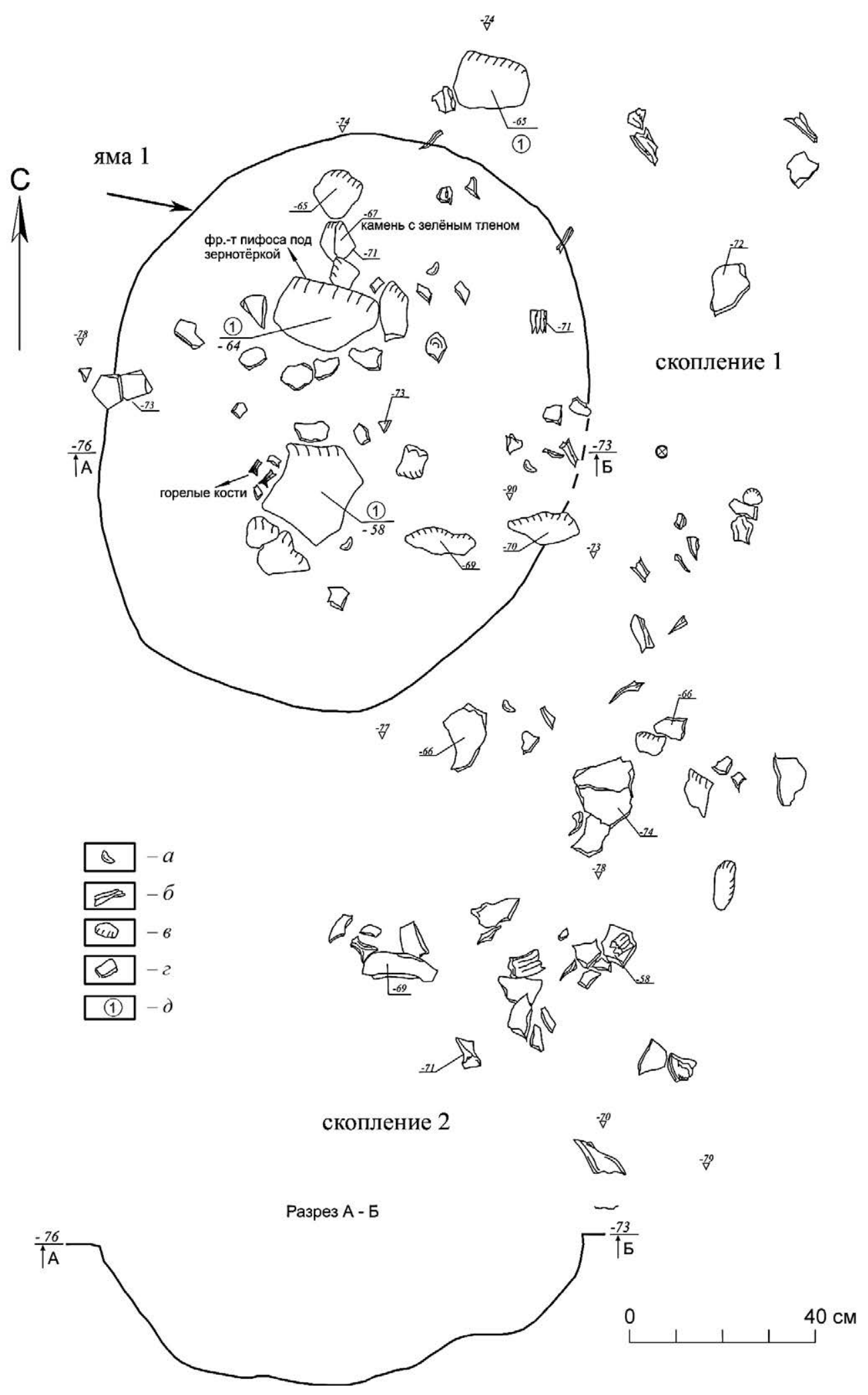

Рис. 40. Раскоп 4. 2013 г. Глубина - -73 - -75 см. Первый уровень расчистки. Скопление камней и камей животных над пятном. Вид с востока

Условнъе обозначения:

$a$ - ракушки, б- кости животных, в-камни, г-керамика, д- фрагмент зернотерки 


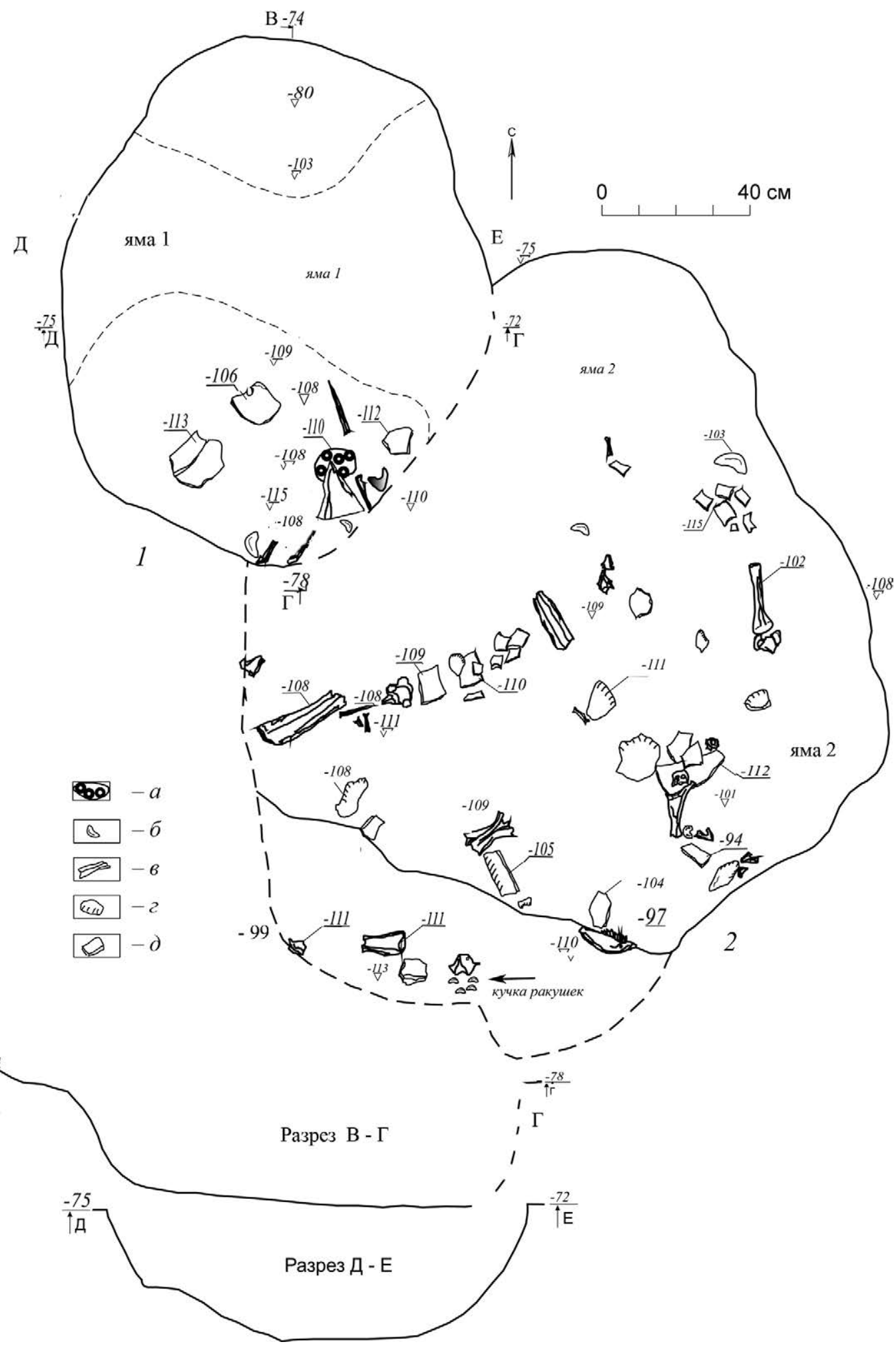

Рис. 41. Раскоп 4. 2013 г. Второй и третий уровни фиксации

1 - яма 1, глубина -73 - -76 см, 2 - глубина восточной части контура -75 см. Западный контур ямы еще не прослеживается

Условнъе обозначения:

$a$ - скопление ракушки, б-кучка ракушек, в-кость, г-камень, д-керамика 


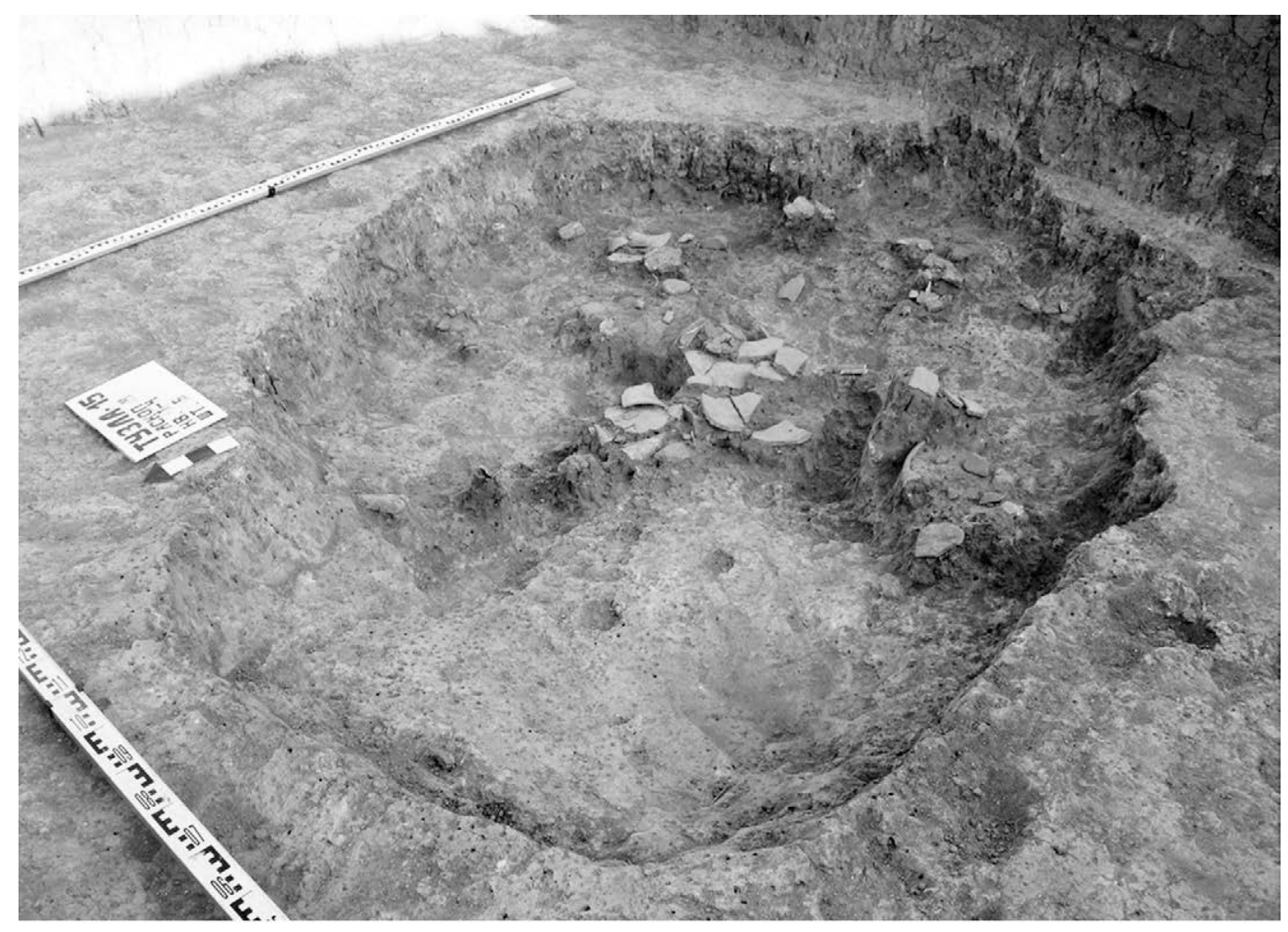

Рис. 42. Раскоп 4. 2013 г. Постройка З. Вид с северо-запада

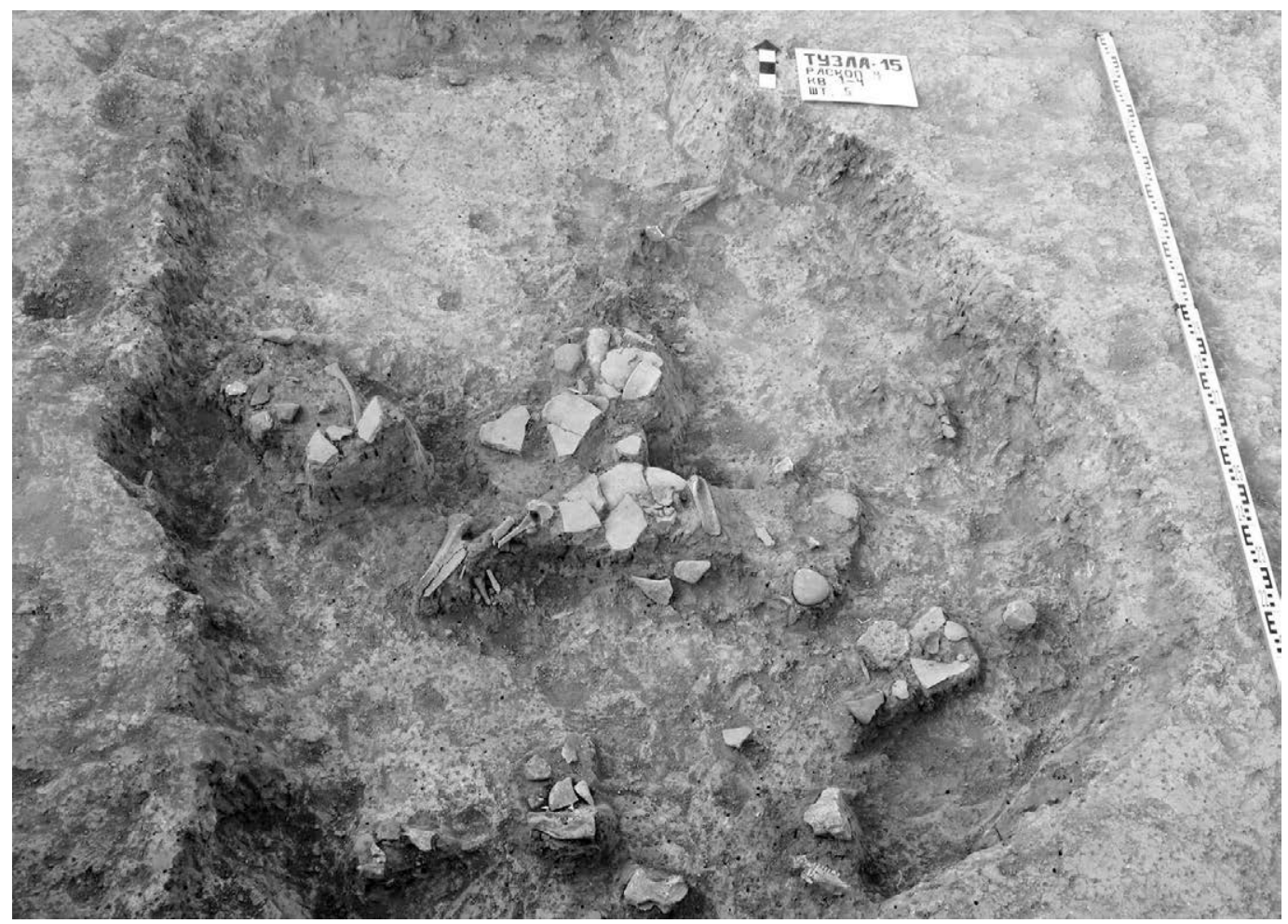

Рис. 43. Раскоп 4. 2013 г. Постройка 3. Вид с юга 

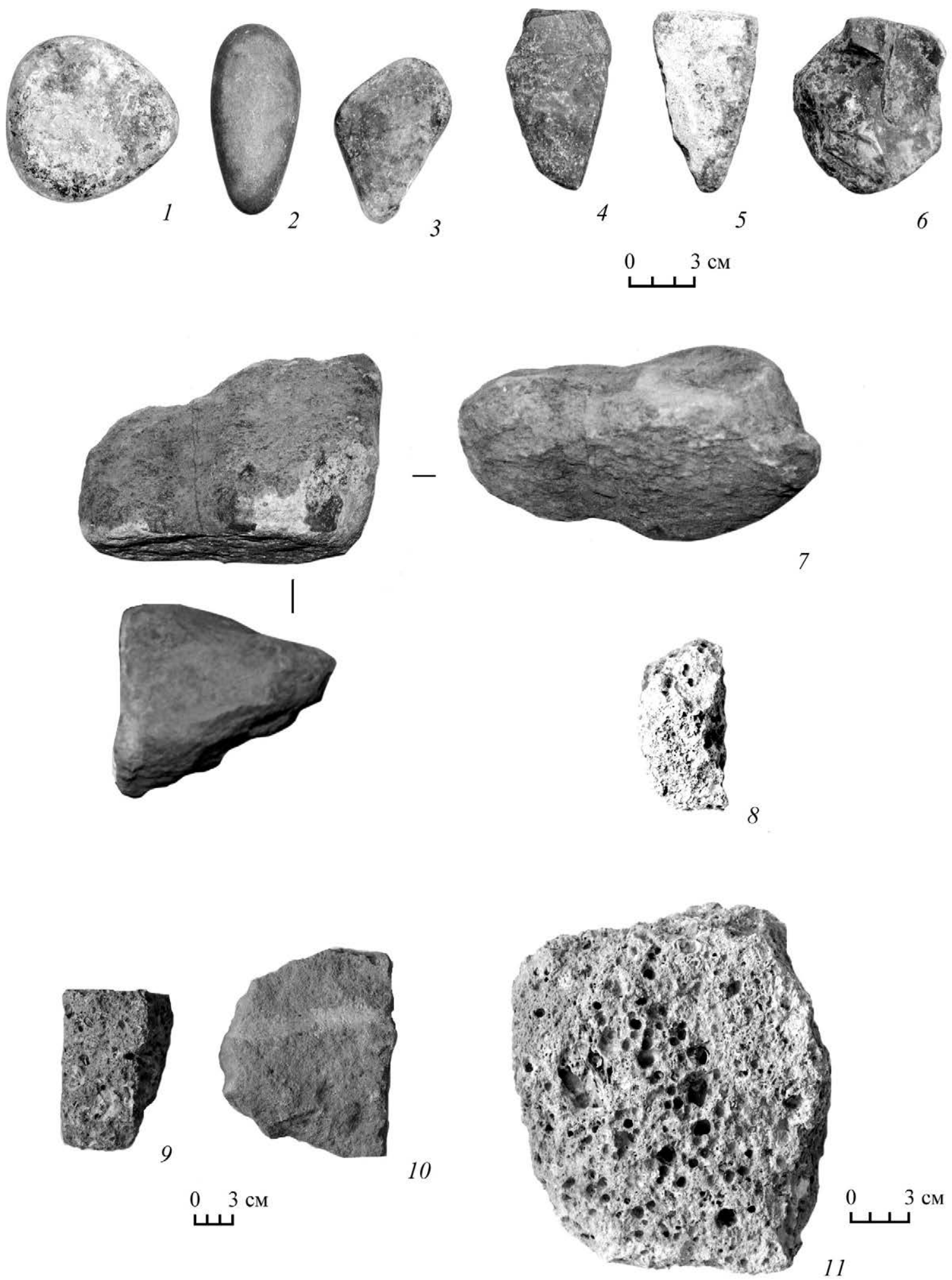

Рис. 44. Раскоп 4. 2013 г. Постройка 3. Находки в постройке 3

1-3- гальки, 4-6- камни, конгломерат, 7- камень зеленого цвета, 8-10- камень - песчаник 

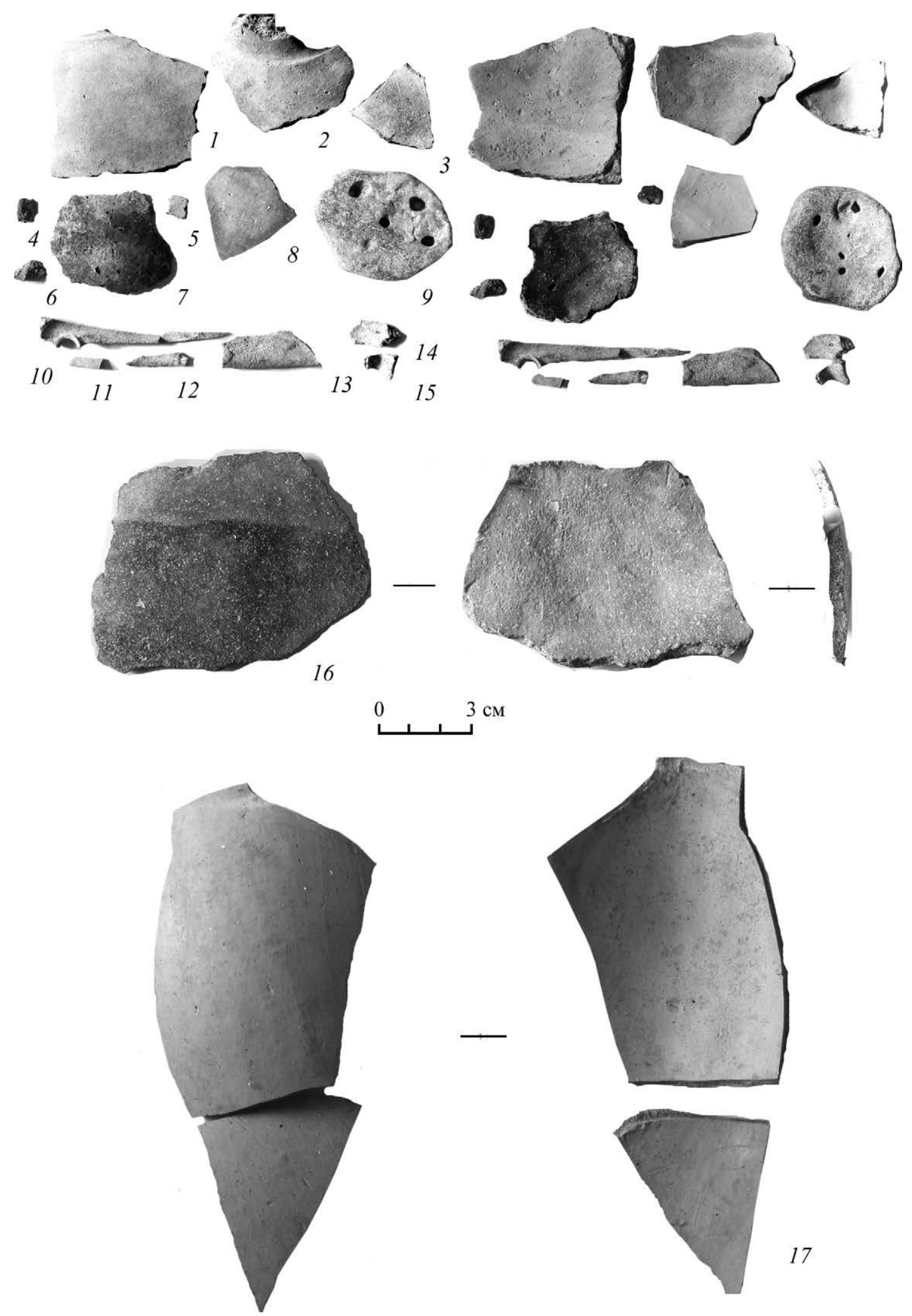

Рис. 45. Раскоп 4. 2013 г. Постройка 3. Находки

1-9, 13-17- керамика, 10-12- кости животных 

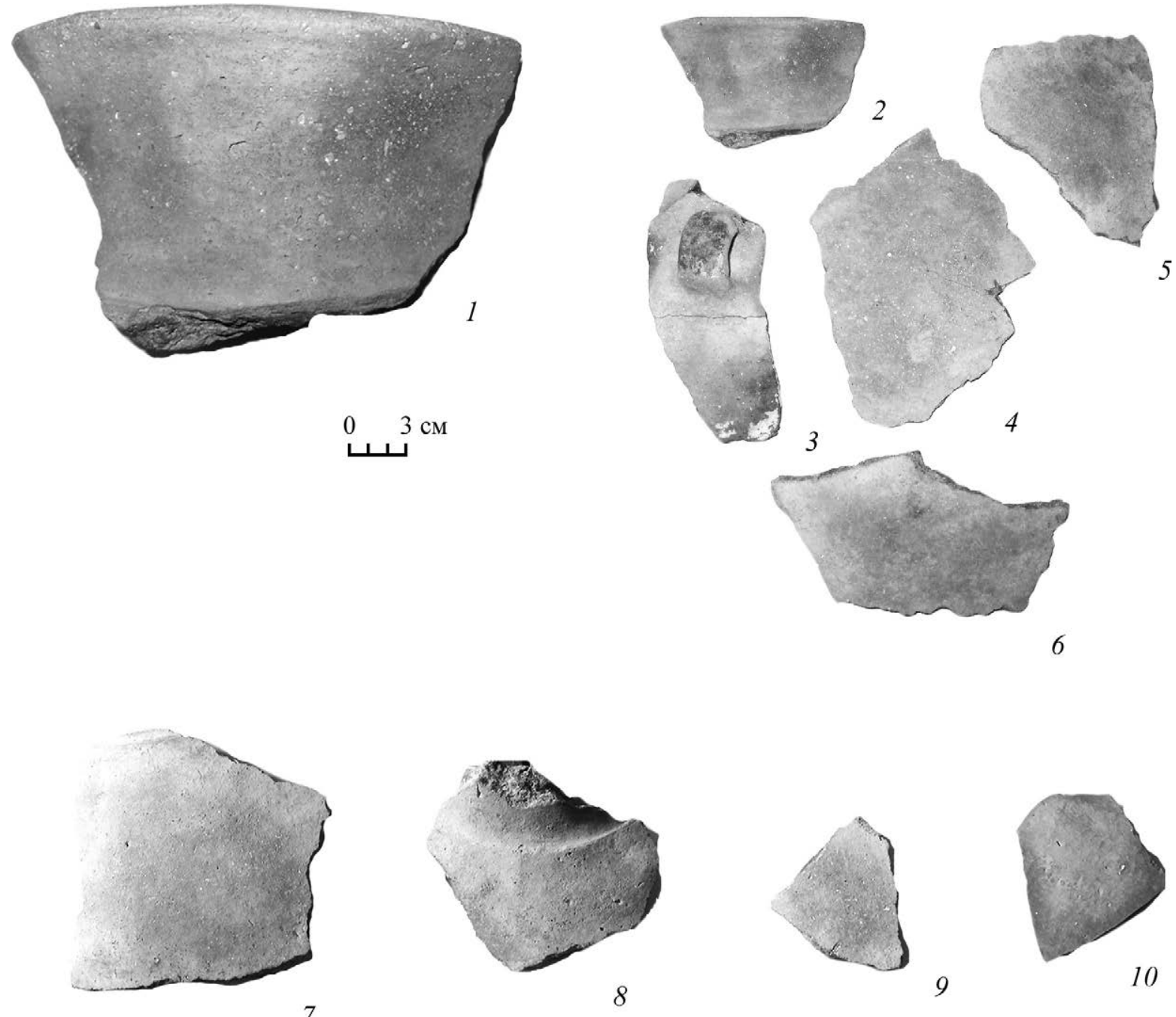

Рис. 46. Раскоп 4. 2013 г. Постройка 3. Керамика 


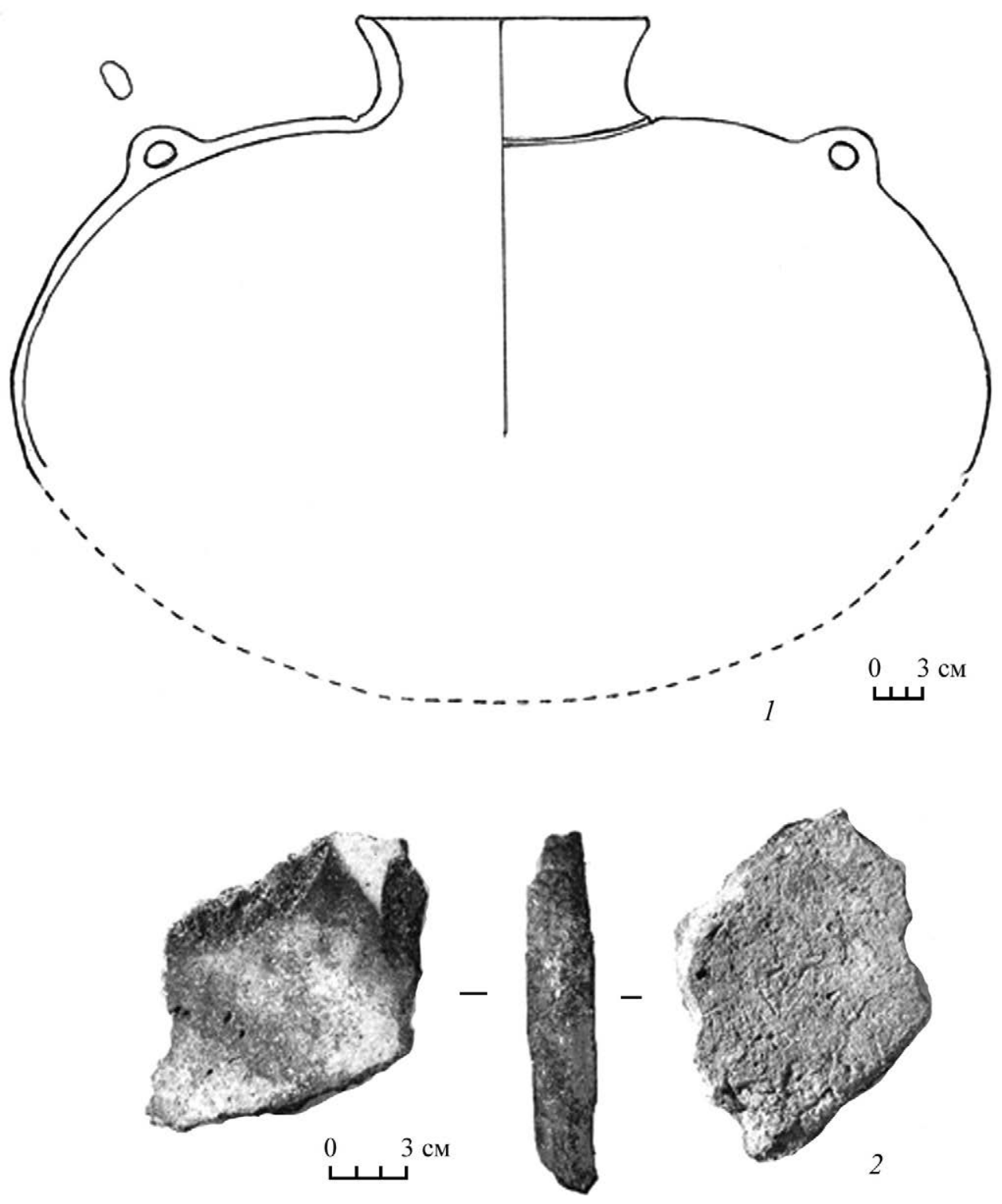

Рис. 47. Раскоп 4. 2013 г. Постройка 3. Керамика

1 - Реконструкция сосуда, 2 - фрагменты плоского дна 

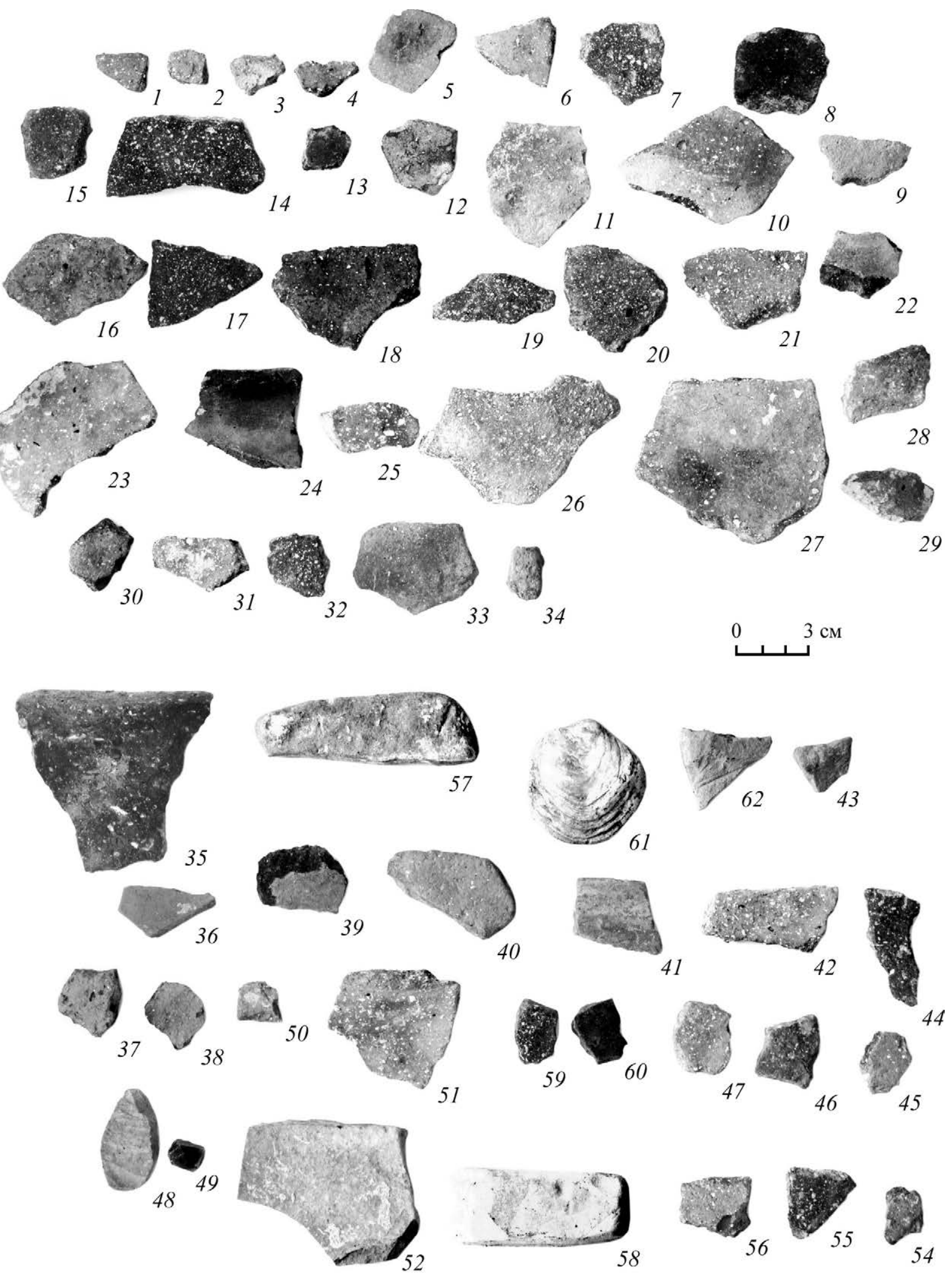

1
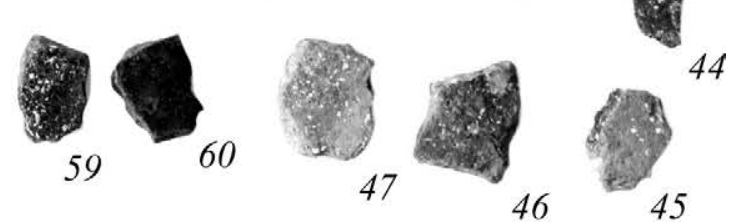

Рис. 48. Раскоп 4. 2013 г. Постройка 3. Керамика и раковины 


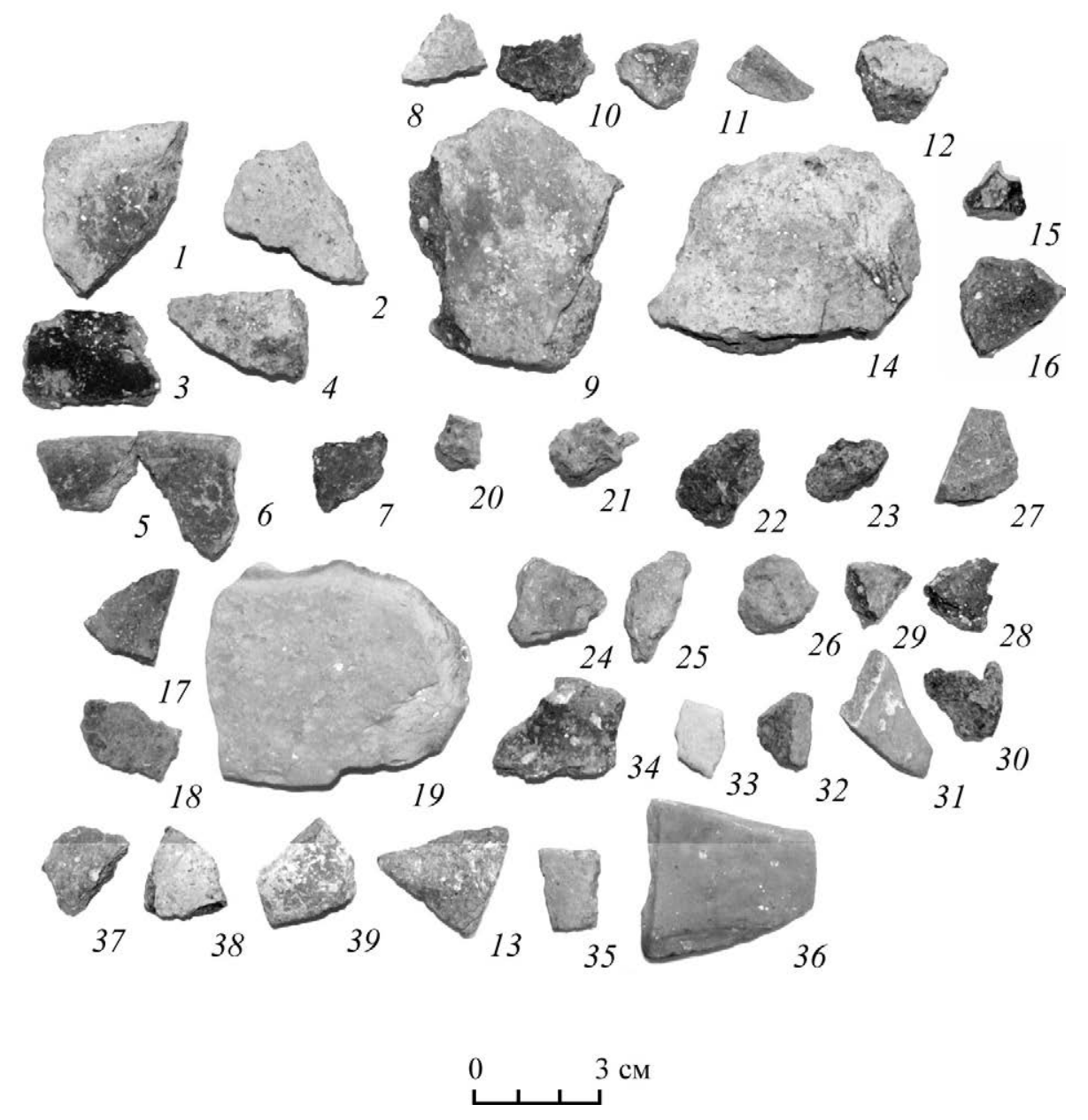

Рис. 49. Раскоп 4. 2013 г. Постройка З. Камни из постройки 

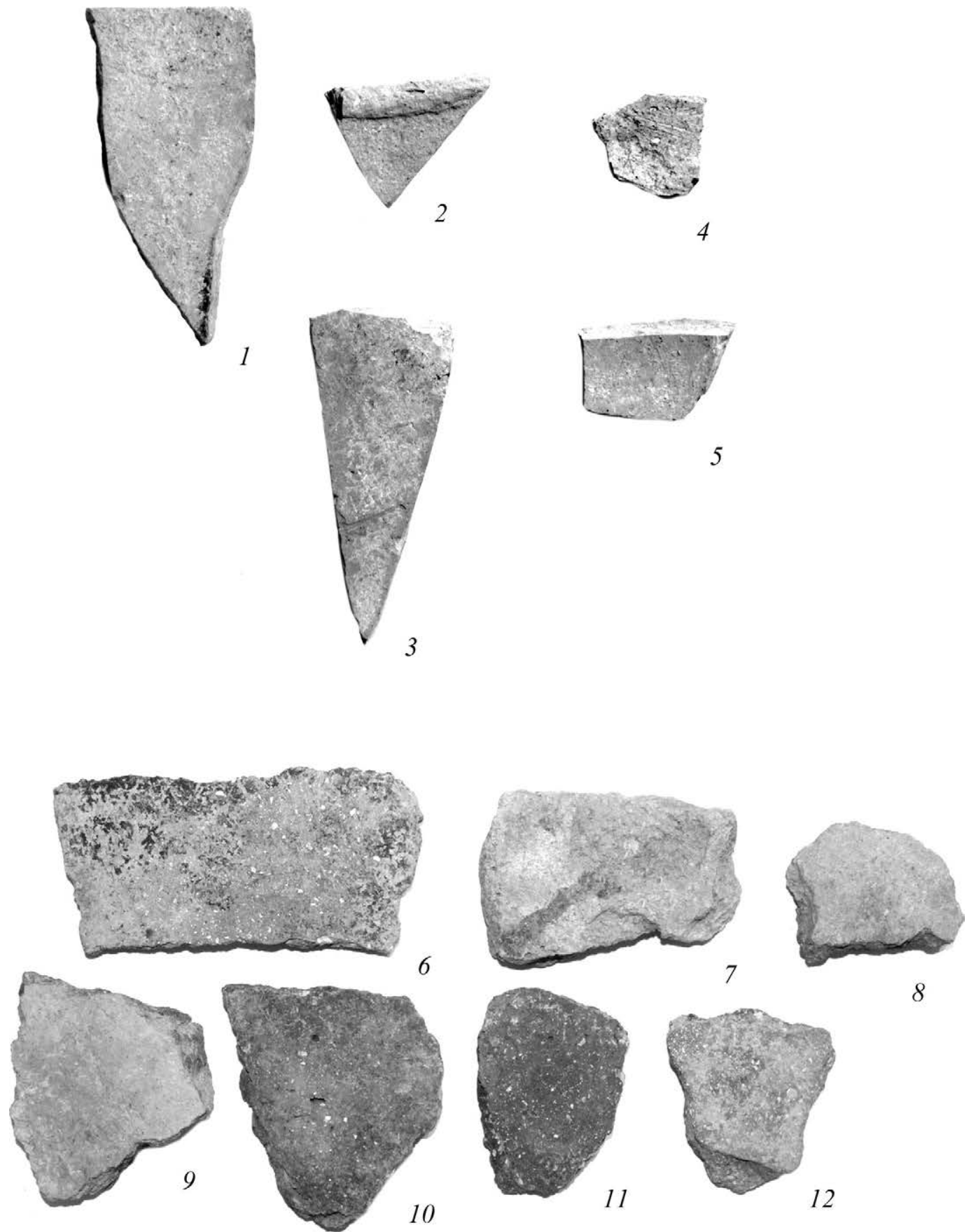

8
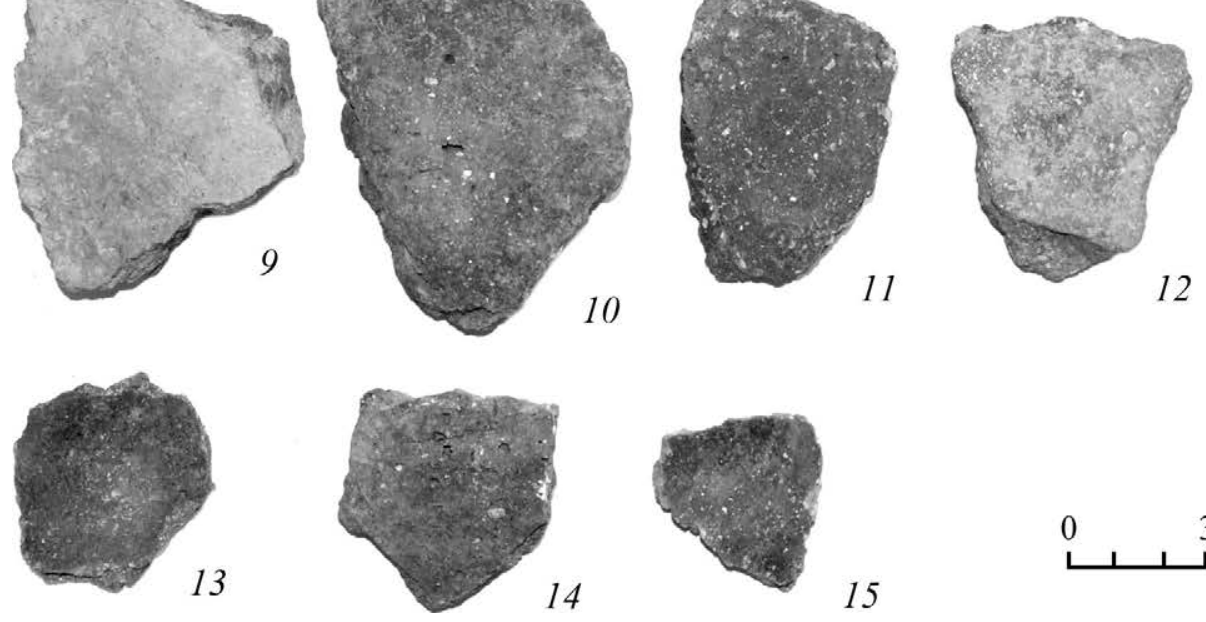

Рис. 50. Раскоп 4. 2013 г. Постройка 3. Керамика 

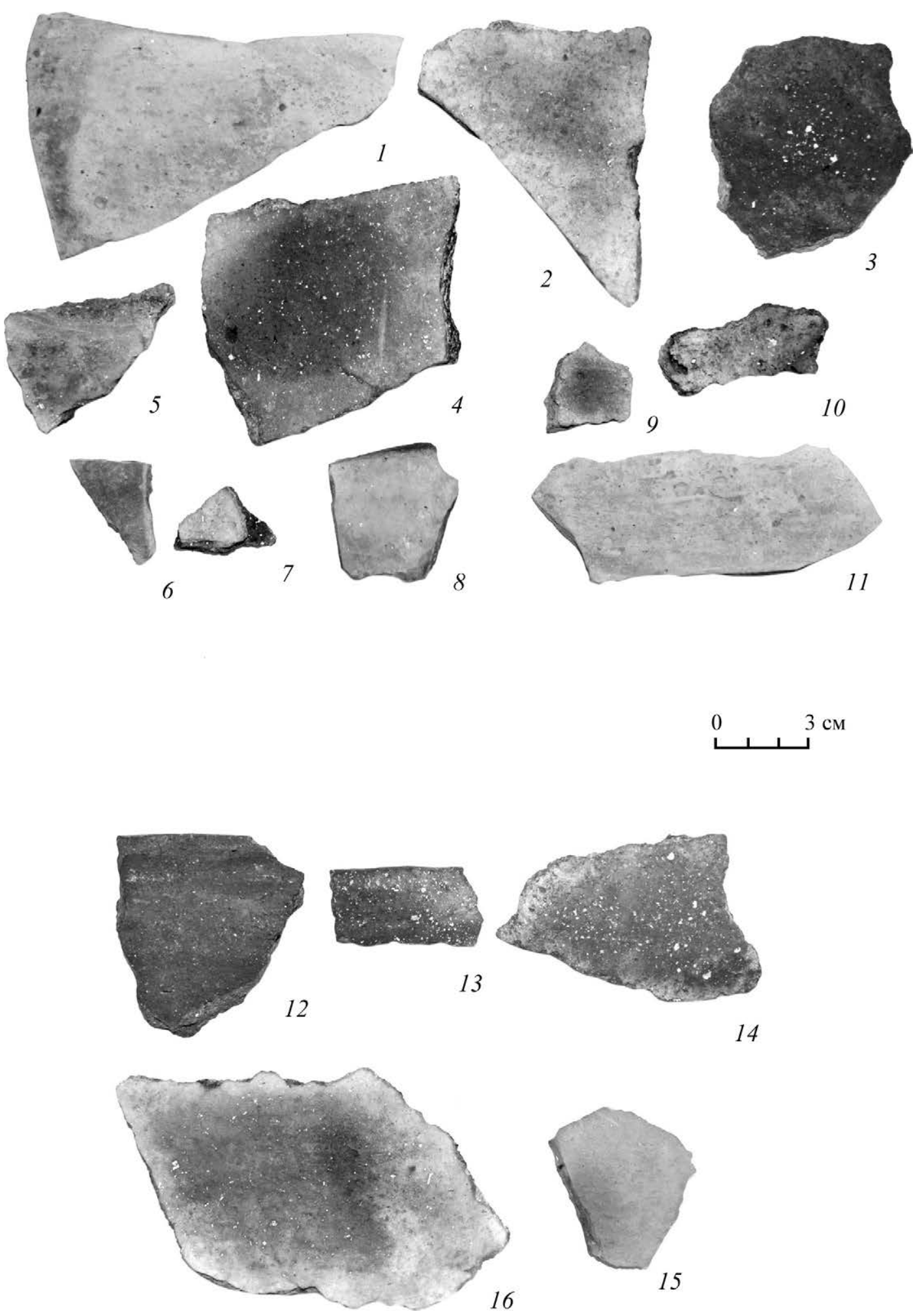

Рис. 51. Раскоп 4. 2013 г. Постройка 3. Керамика, орудия. 5 шт. гл -113 - -149 см. 


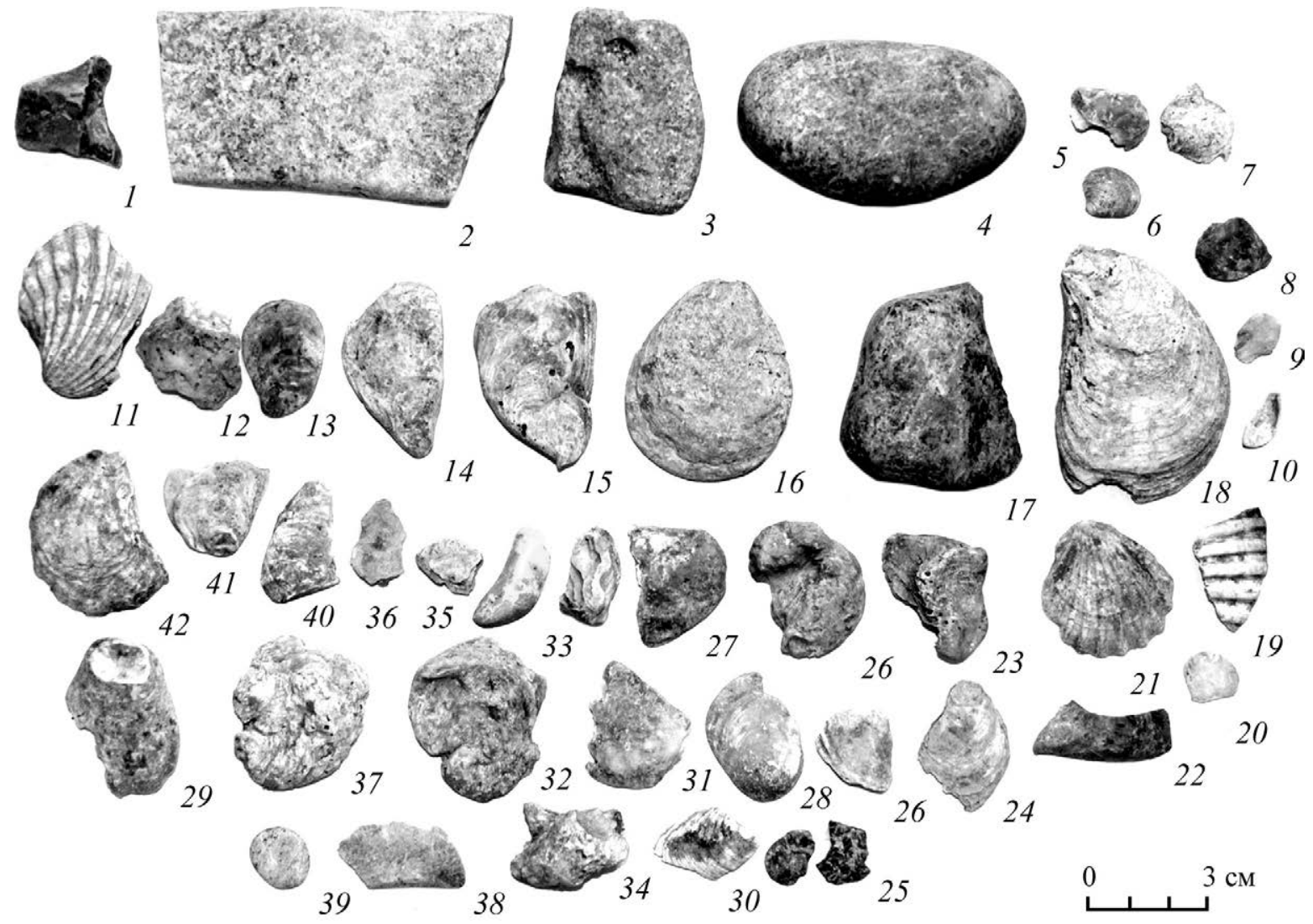

Рис. 52. Раскоп 4. 2013 г. Постройка 3. Керамика и раковины 

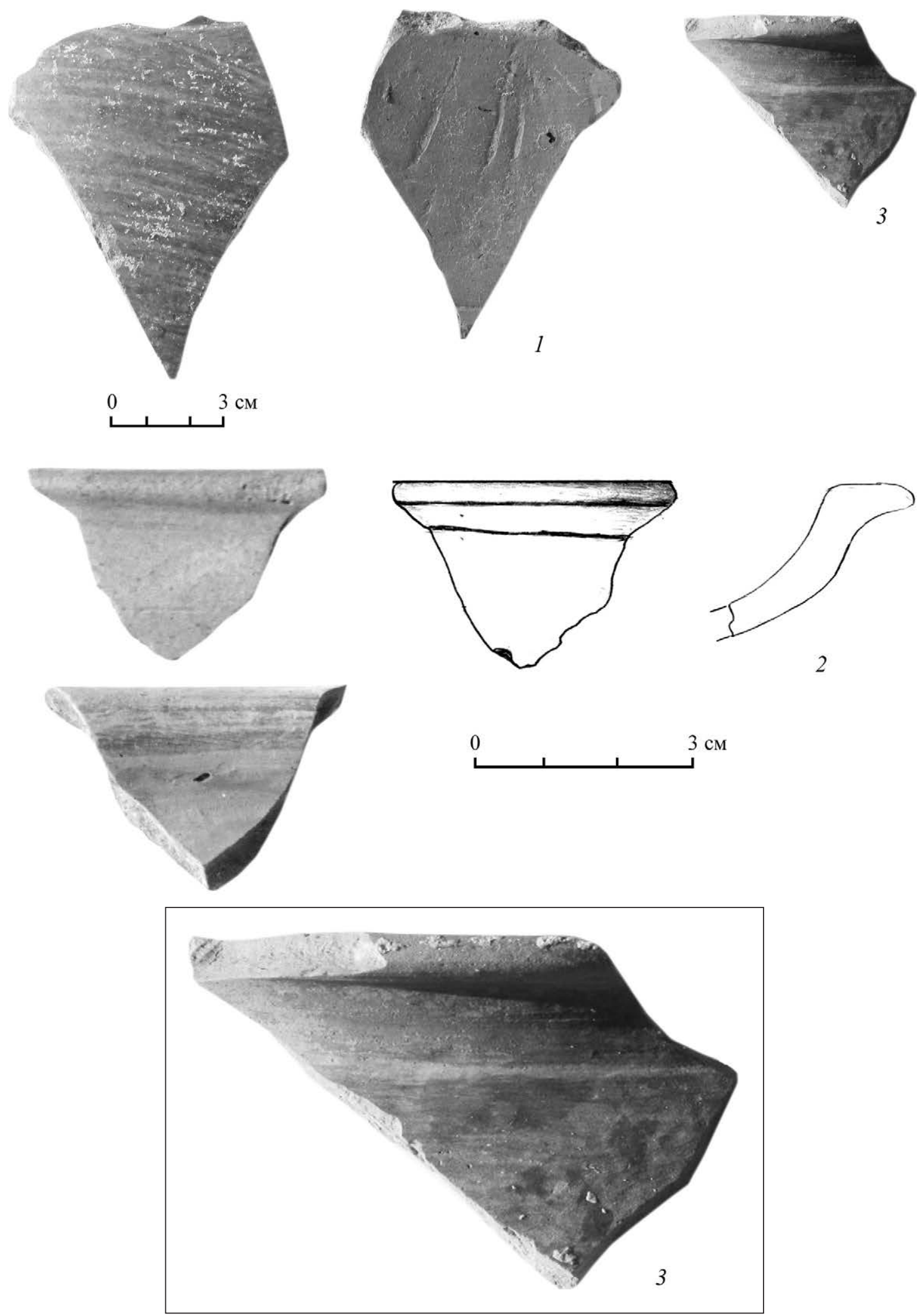

Рис. 53. Раскоп 4. 2013 г. Постройка 3. Керамика со следами окрашивания 

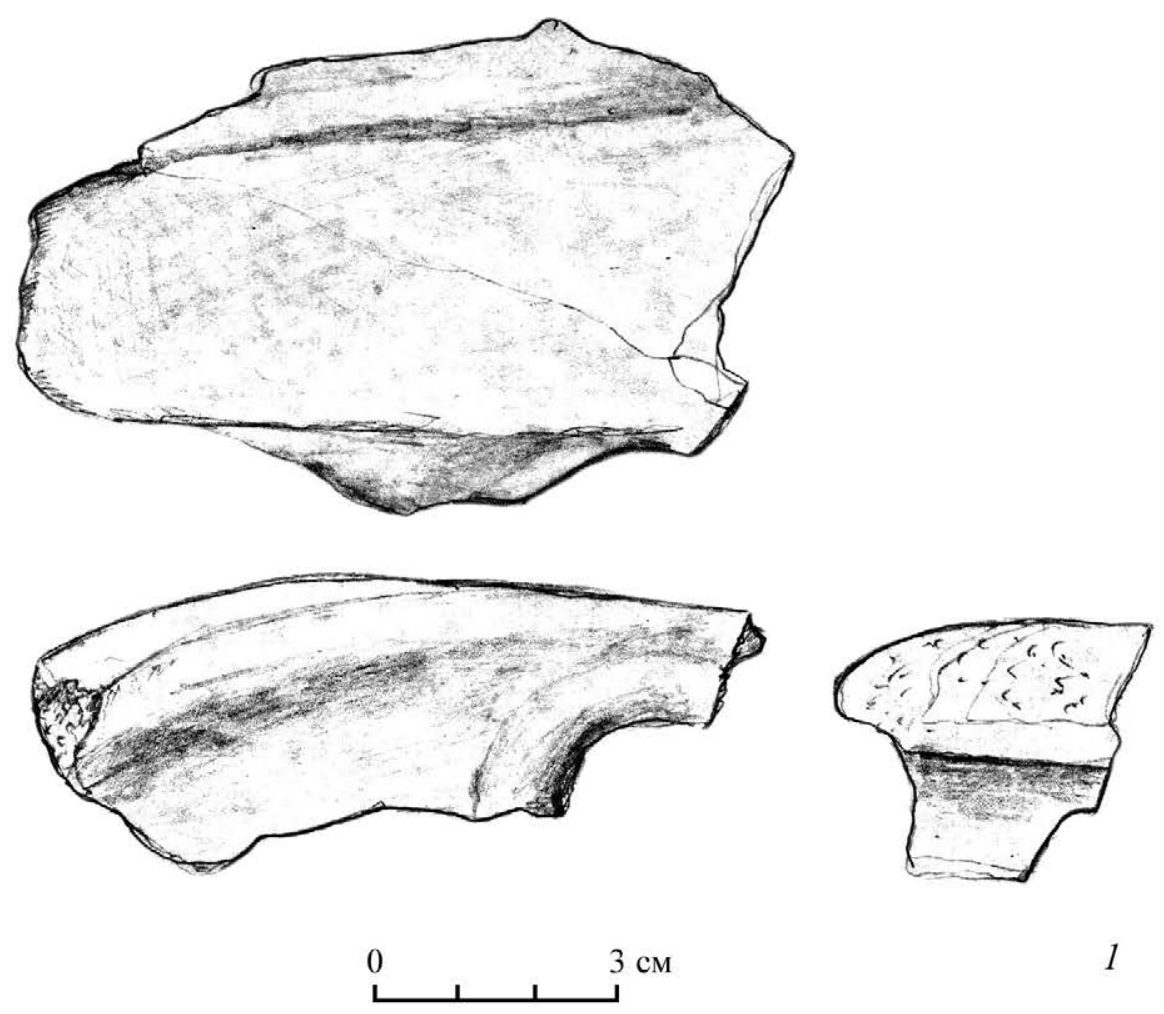

1
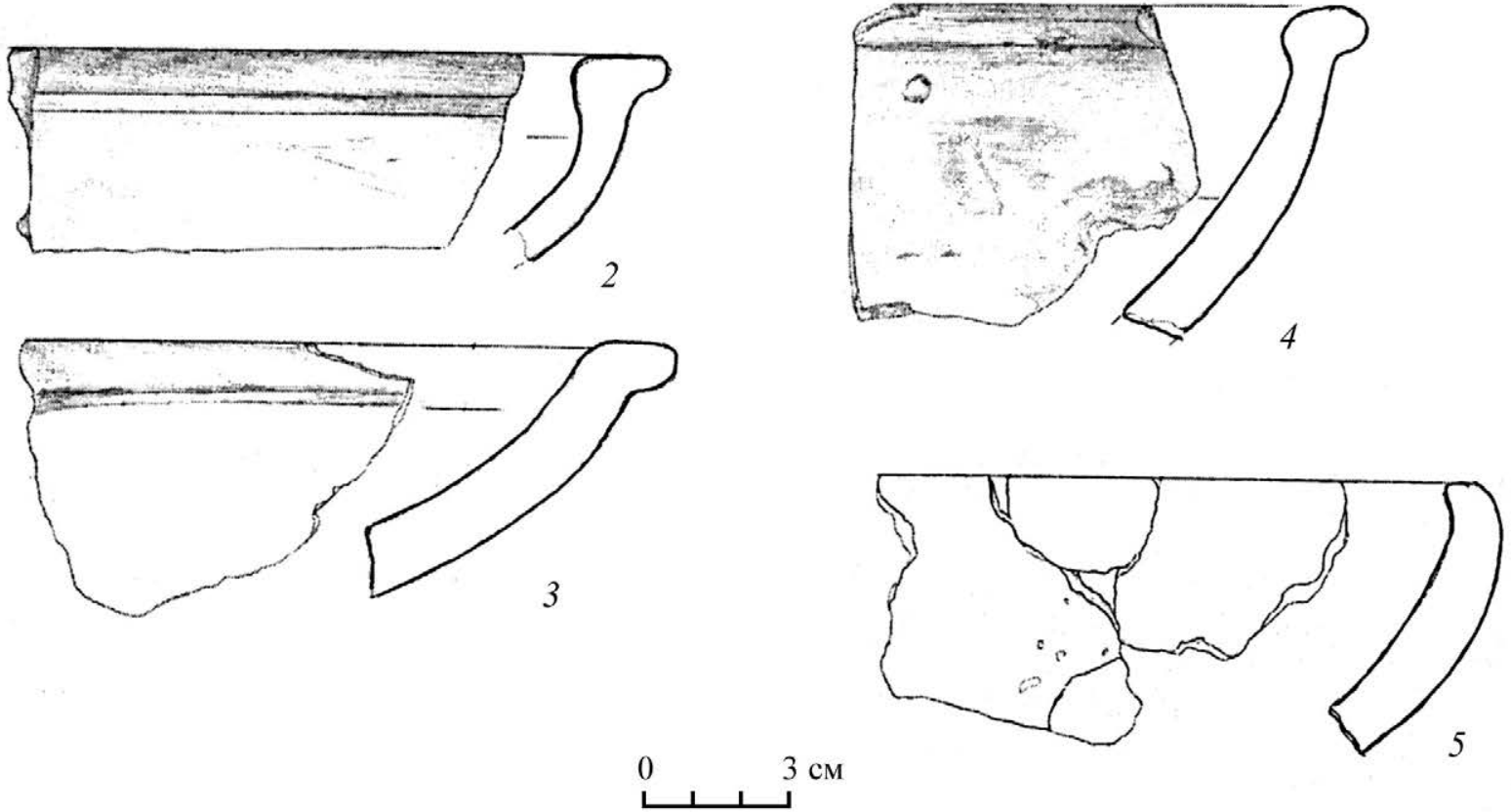

Рис. 54. Раскоп 4. 2013 г. Постройка 3. Навершие глиняной приставки «конуса» и фрагменты мисок 

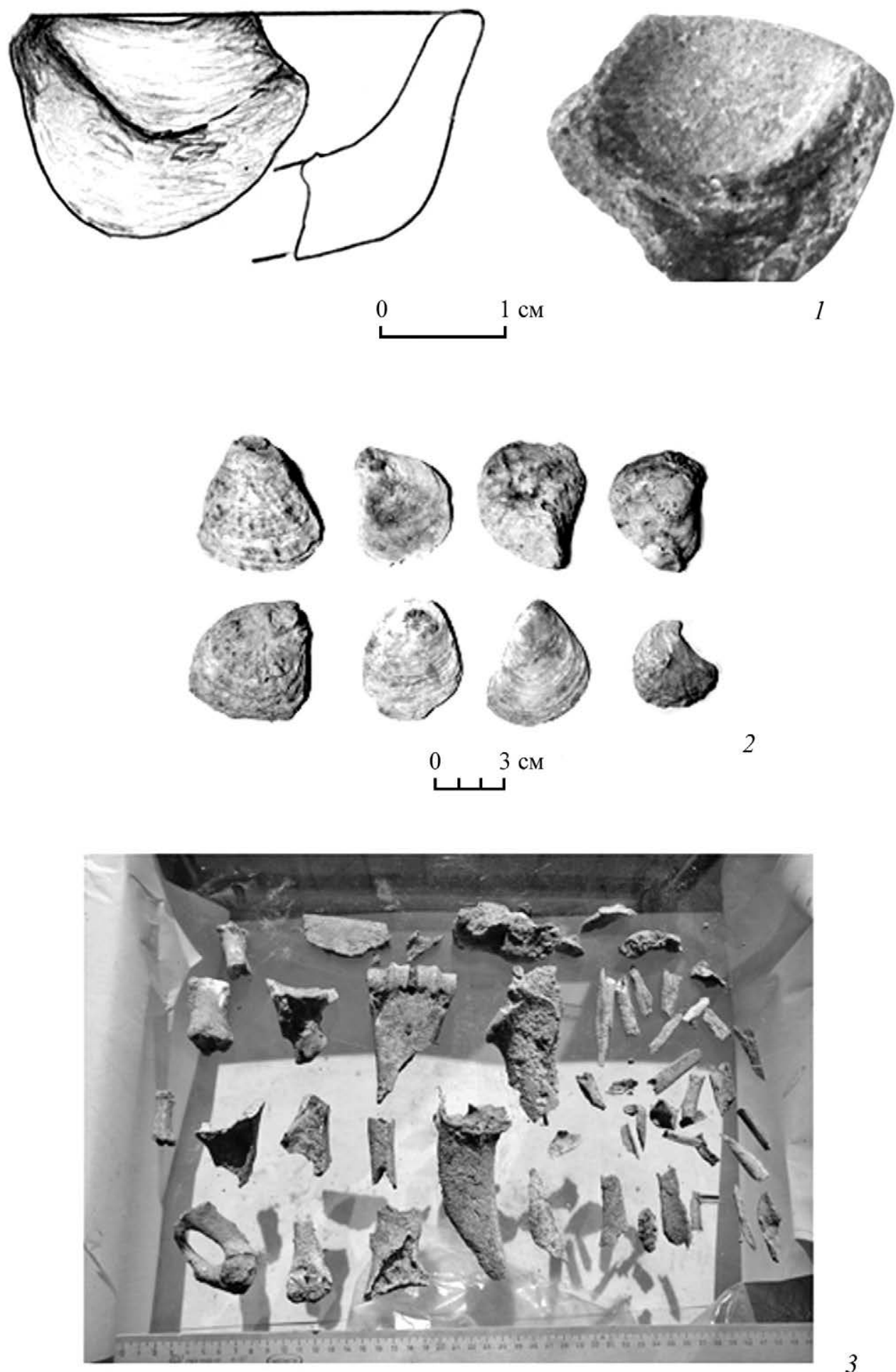

Рис. 55. Раскоп 4. 2013 г. Постройка 3. Находки

1 - фрагмент миски, 2 - раковины, 3 - кости животных 


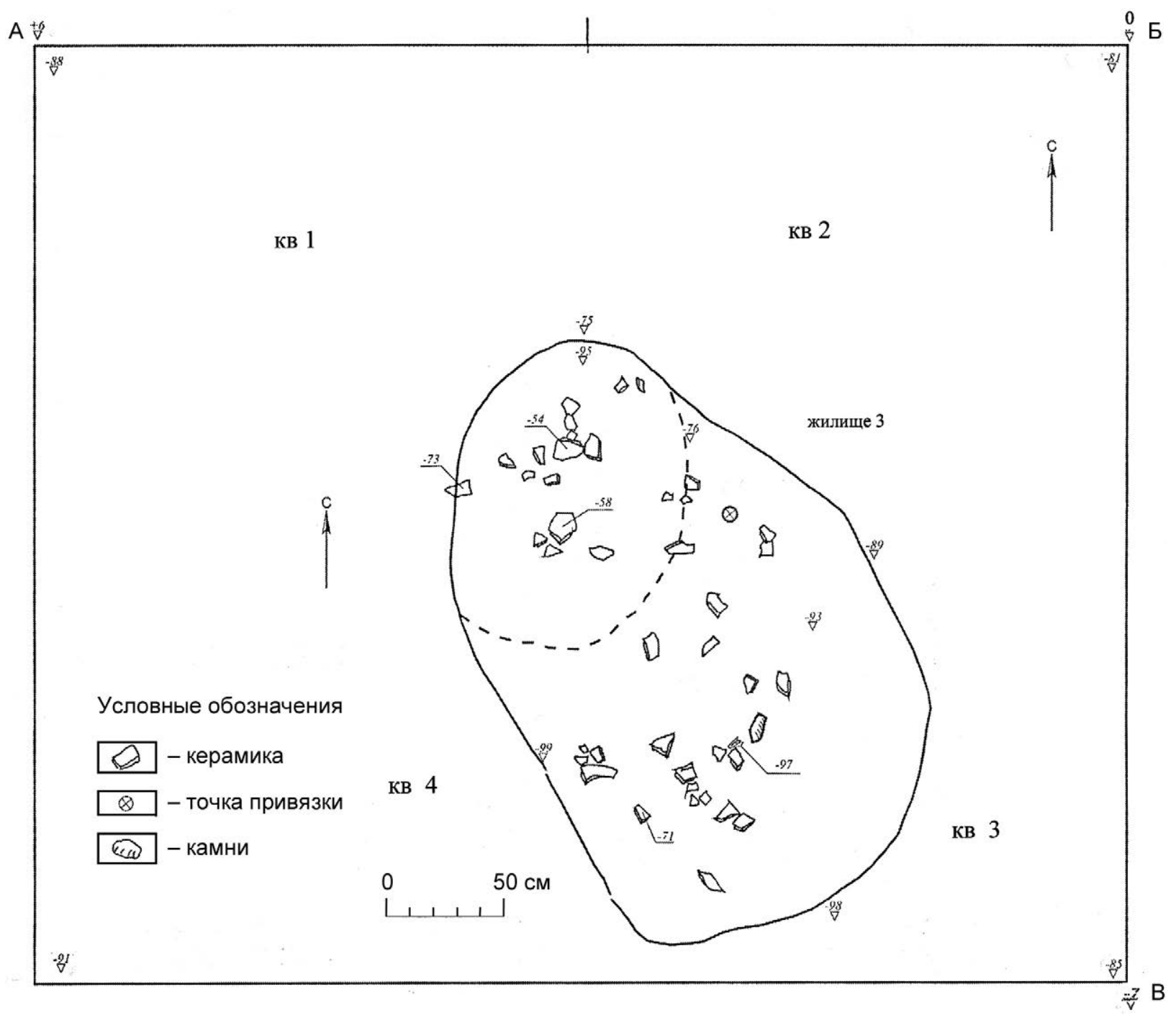

Рис. 56. Раскоп 4. 2013 г. Постройка 3. План-схема 
Северный борт, профиль А-Б

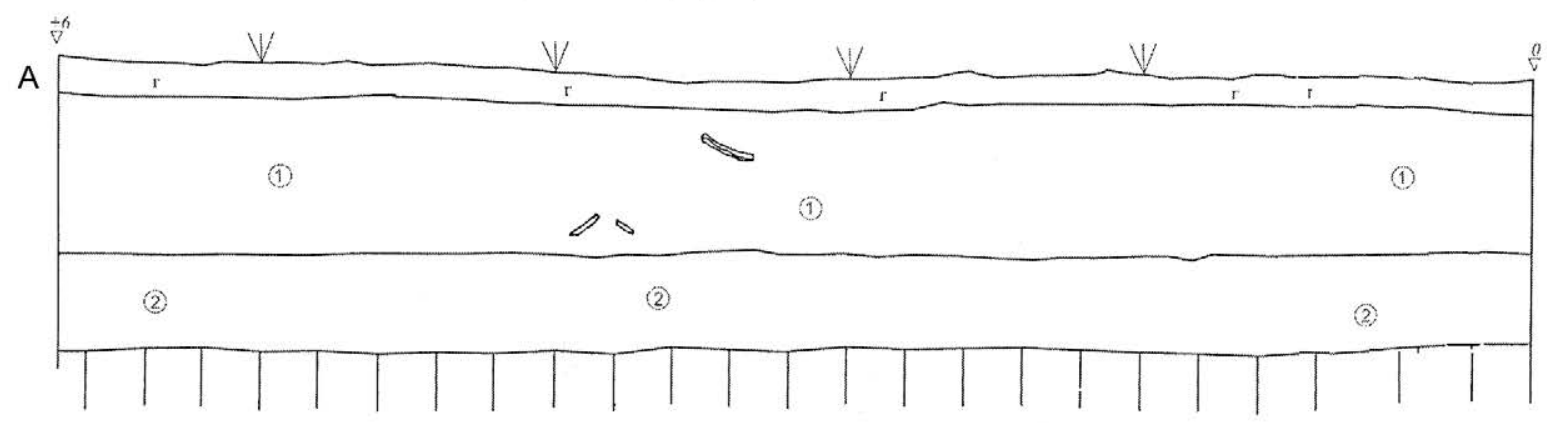

Южный борт, профиль В-Г

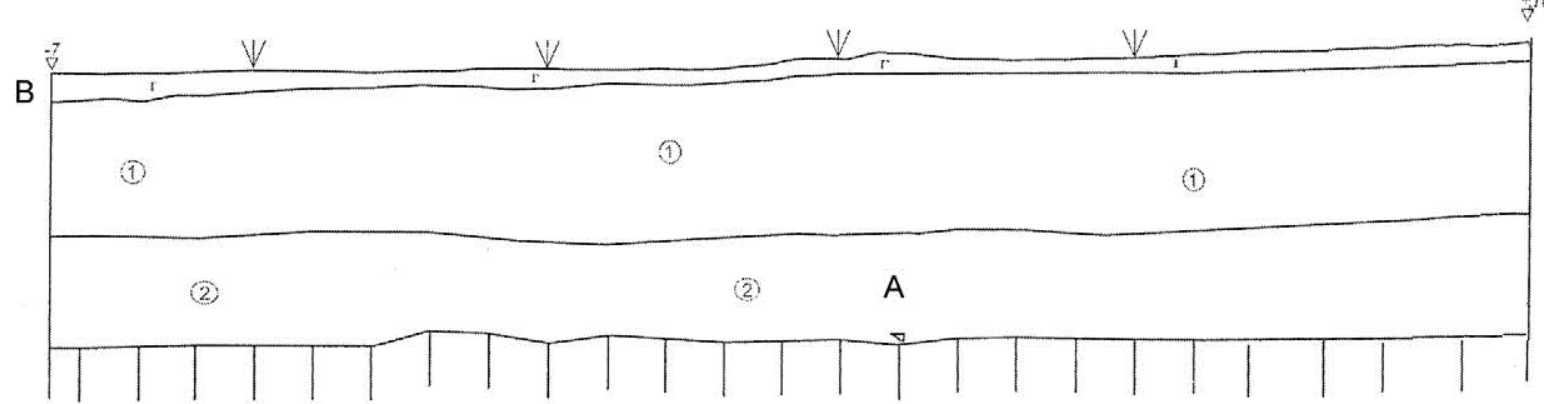

Западный борт, профиль Г-А

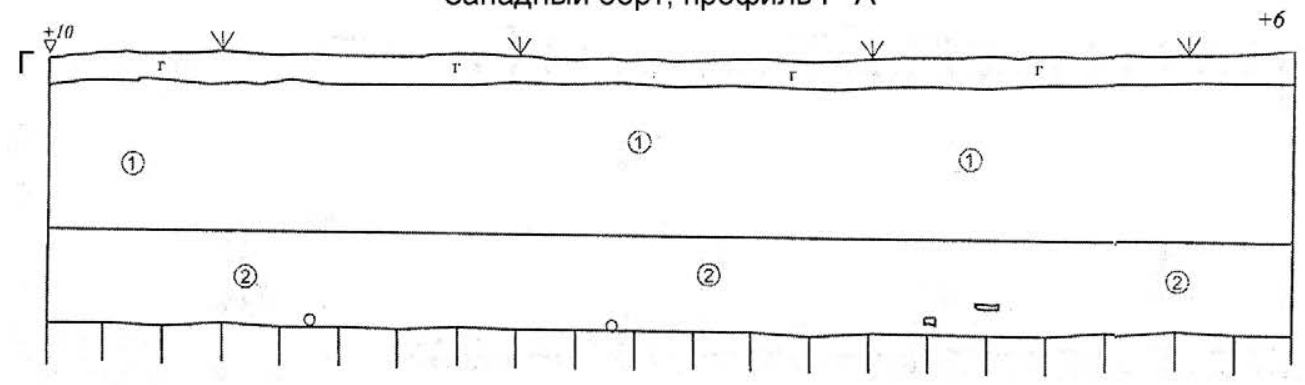

A

Восточный борт, профиль В-Б
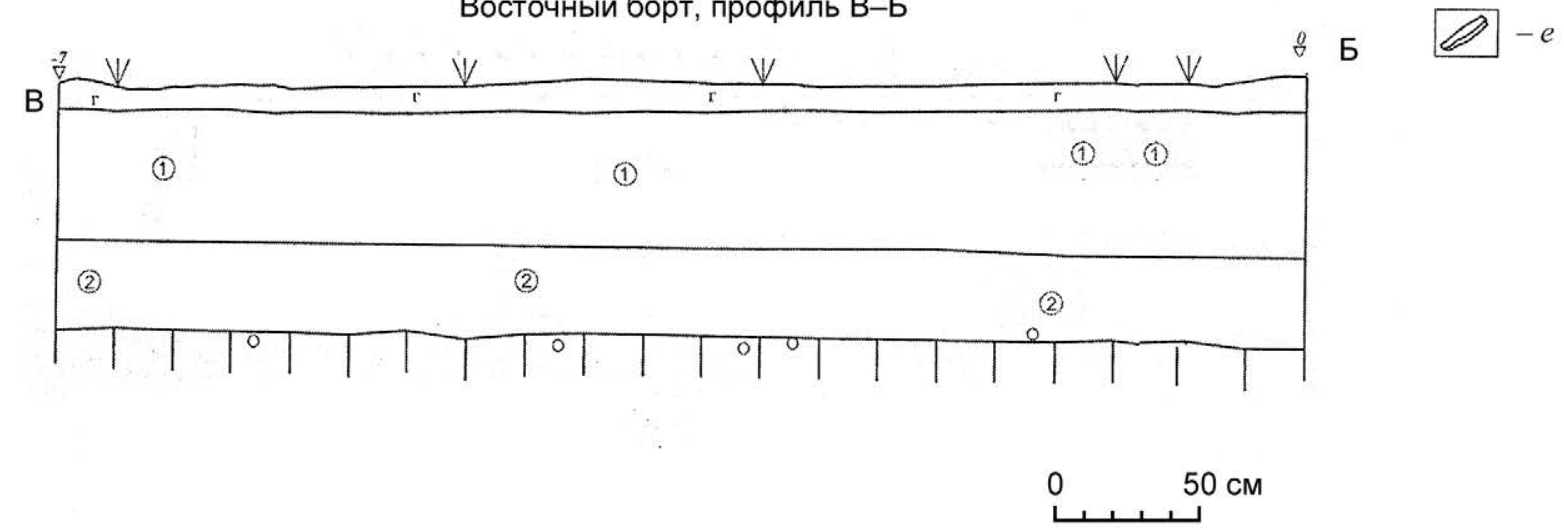

Рис. 57. Раскоп 4. 2013 г. Постройка 3. Профили раскопа

Условные обозначения:

$a$ - гумус, б- пахотный слой, в-культурный слой, г-карбонаты, $\partial$ - материк, $e$ - керамика 
Западный борт, профиль Г-А

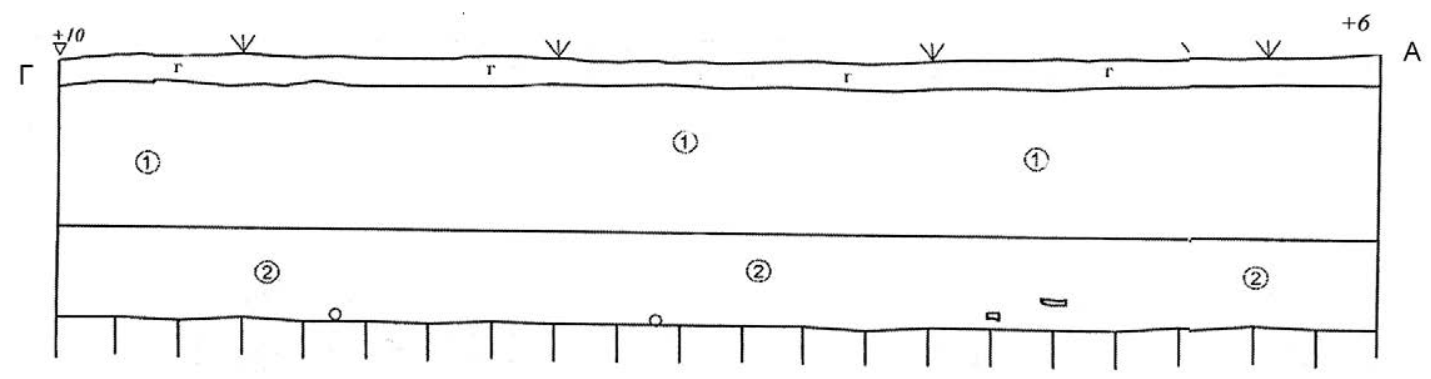

Восточный борт, профиль В-Б

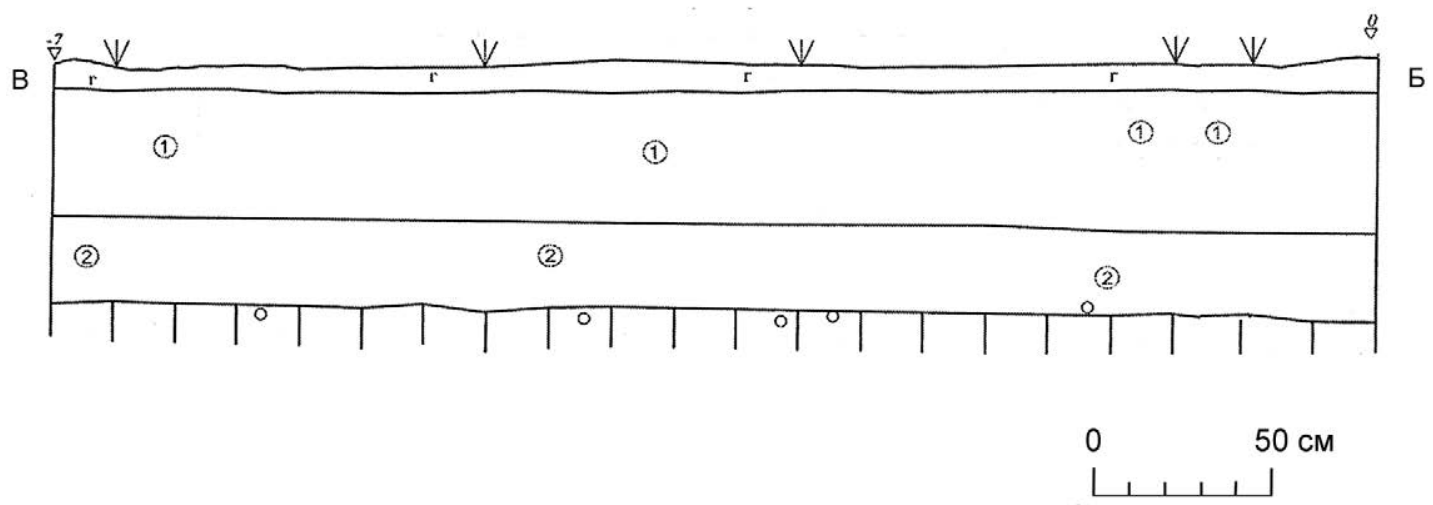

Рис. 58. Профили раскопа 2. 2013 г. (продолжение) 

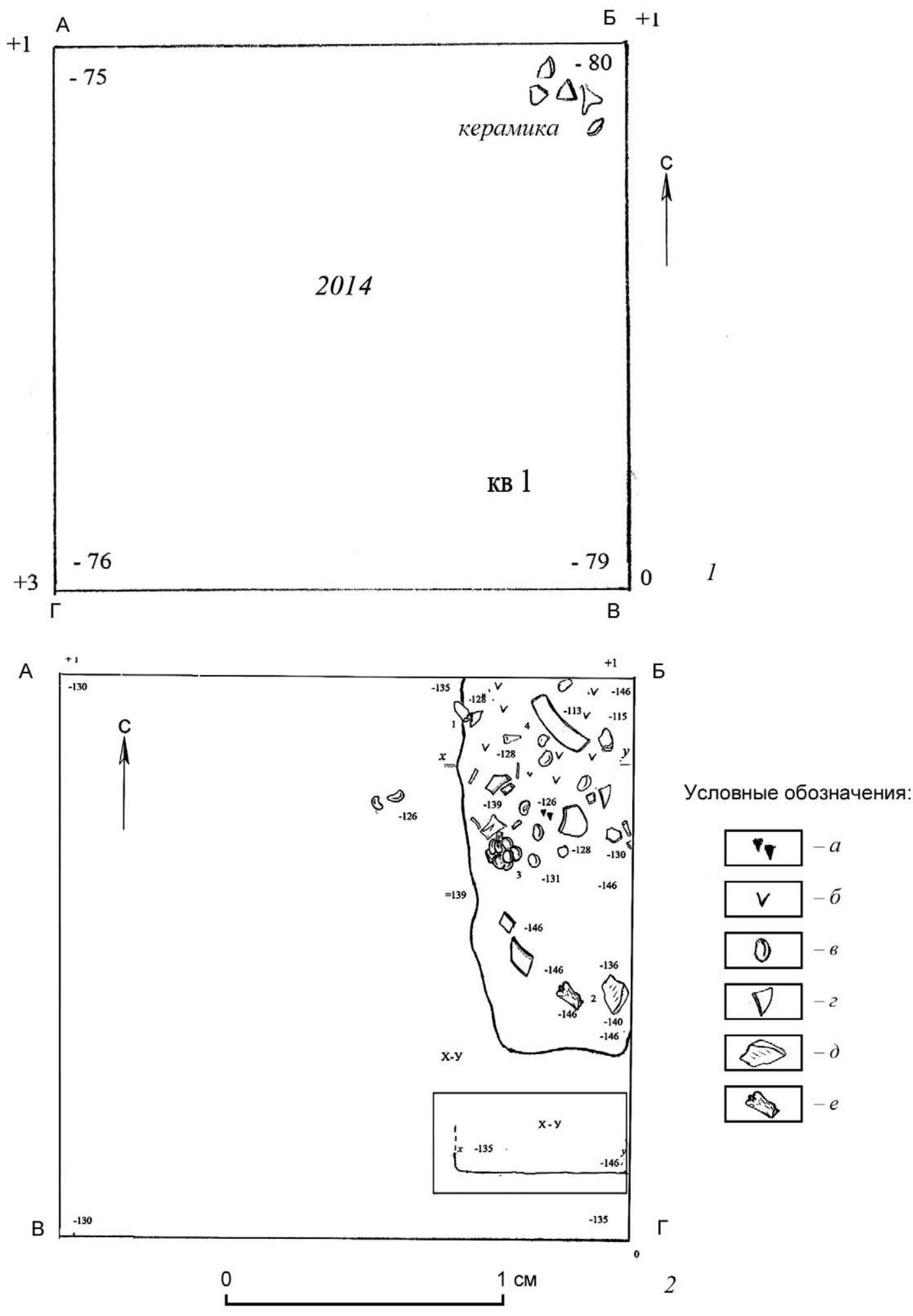

Рис. 59. Раскоп 5. 2014 г. Постройка 4. Начало работ (Квадрат 1)

1 - начало работ, 2 - завершение работ в 2014 г.

Условные обозначения:

$a$-угли, б- зола, в- раковина, г-керамика, д-камень, $e$ - кость 


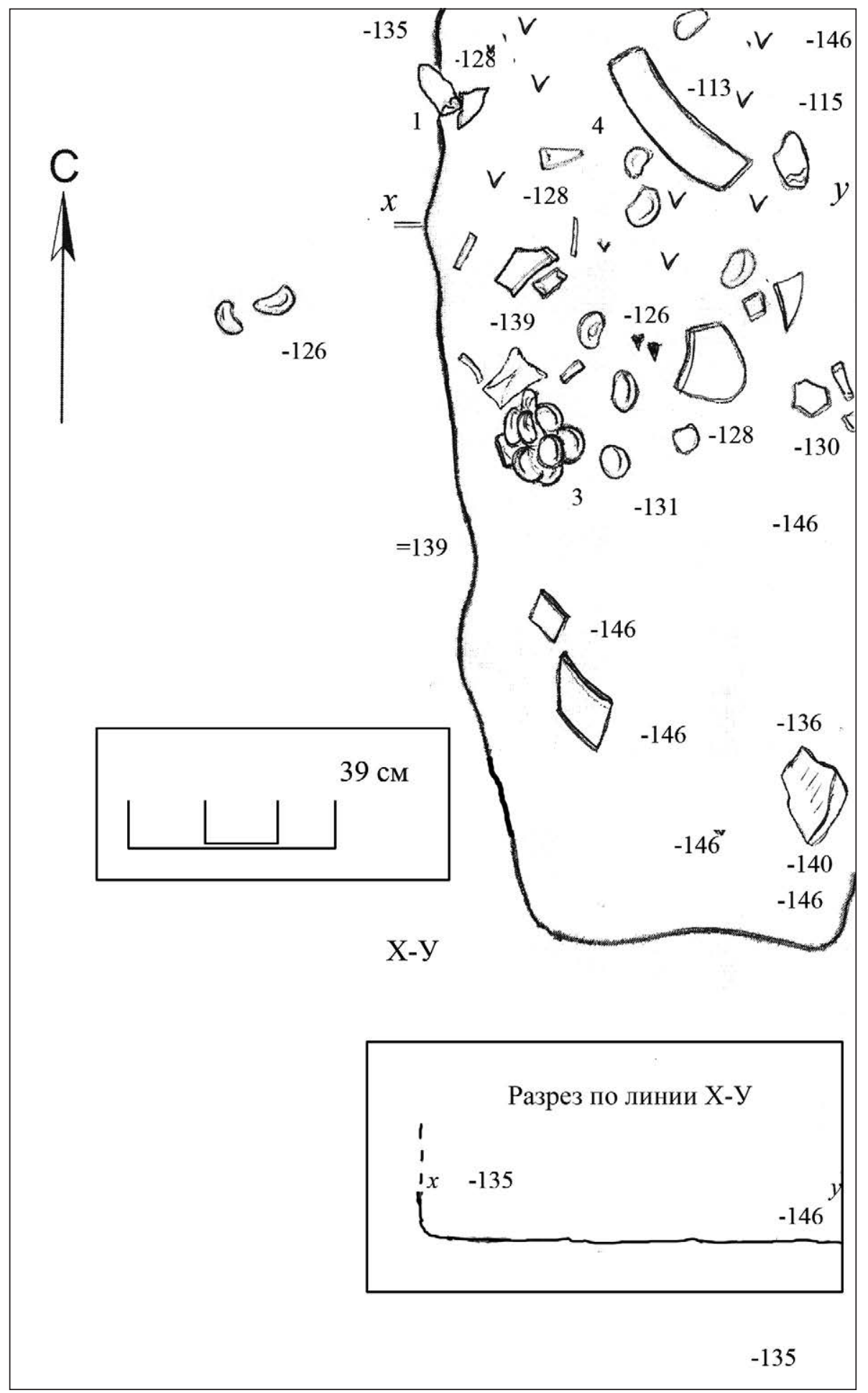

Рис. 60. Раскоп 5. 2014 г. Постройка 4. Начало работ, крупный план (Квадрат 1) 

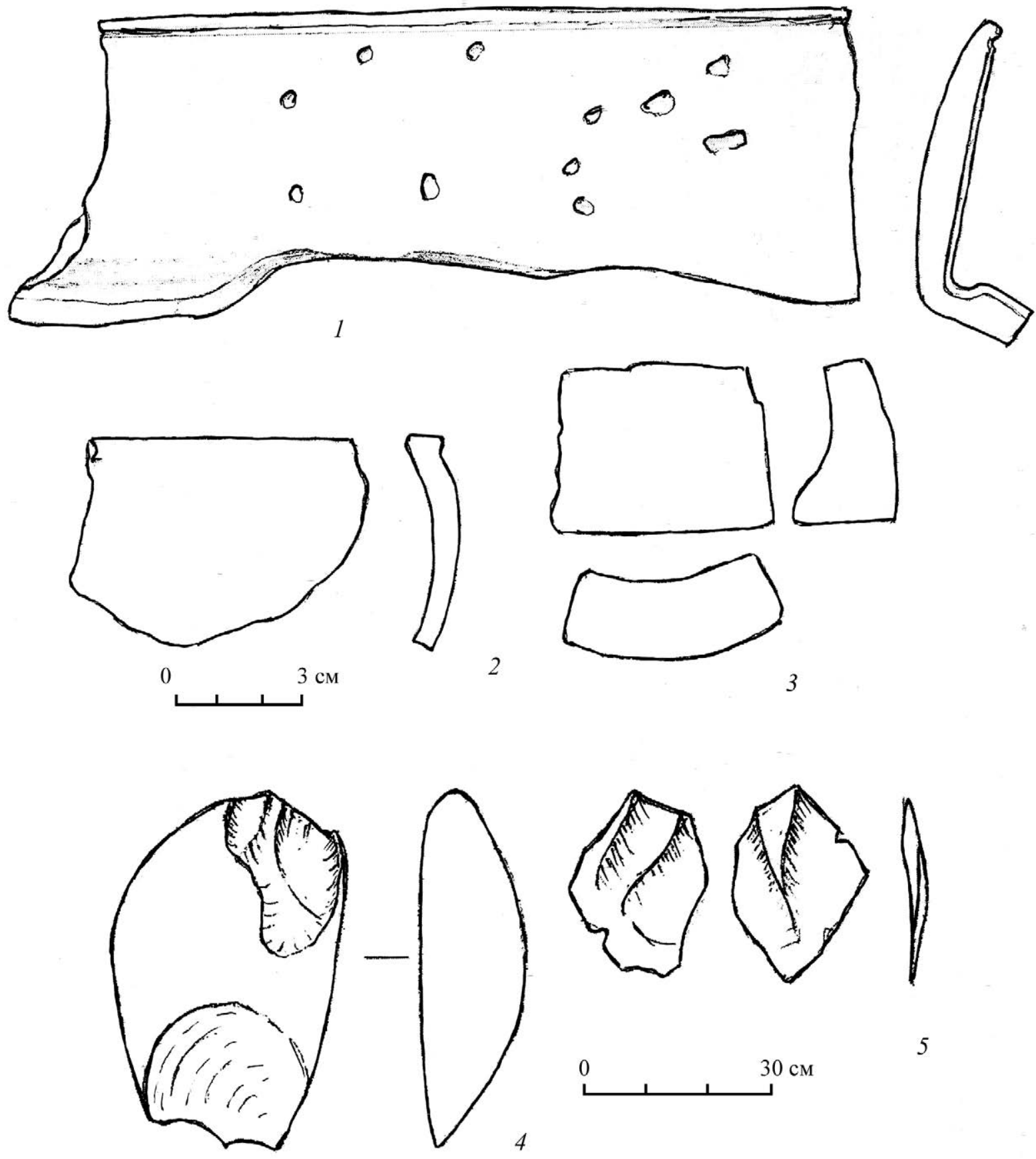

Рис. 61. Раскоп 5. 2014 г Постройка 4. Находки 5 штык, глубина -113 - -149 см. (Квадрат 1) 

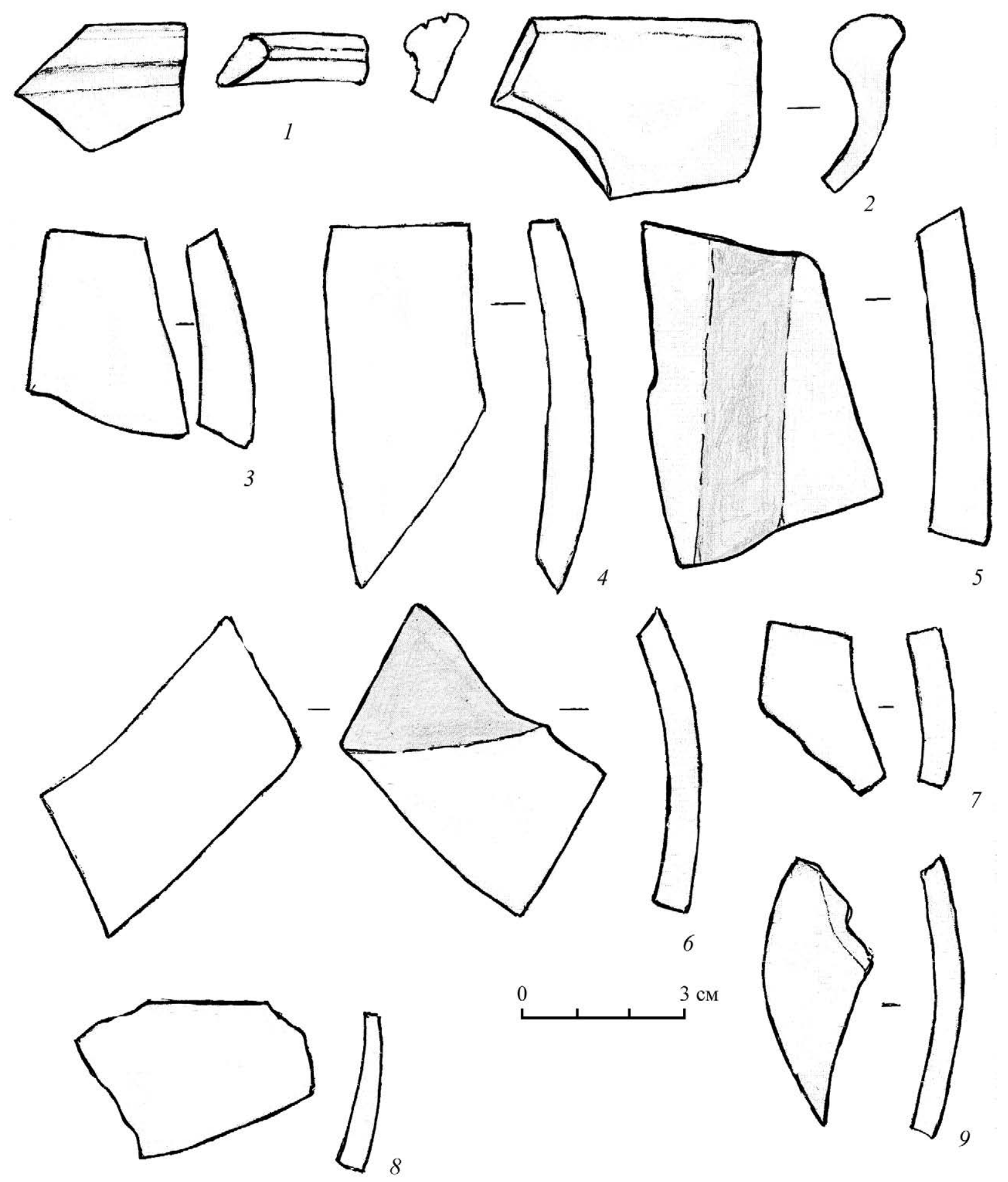

Рис. 62. Раскоп 5. 2014 г. Постройка 4. Находки 5 штык, глубина -113 - -149 см. (Квадрат 1) 

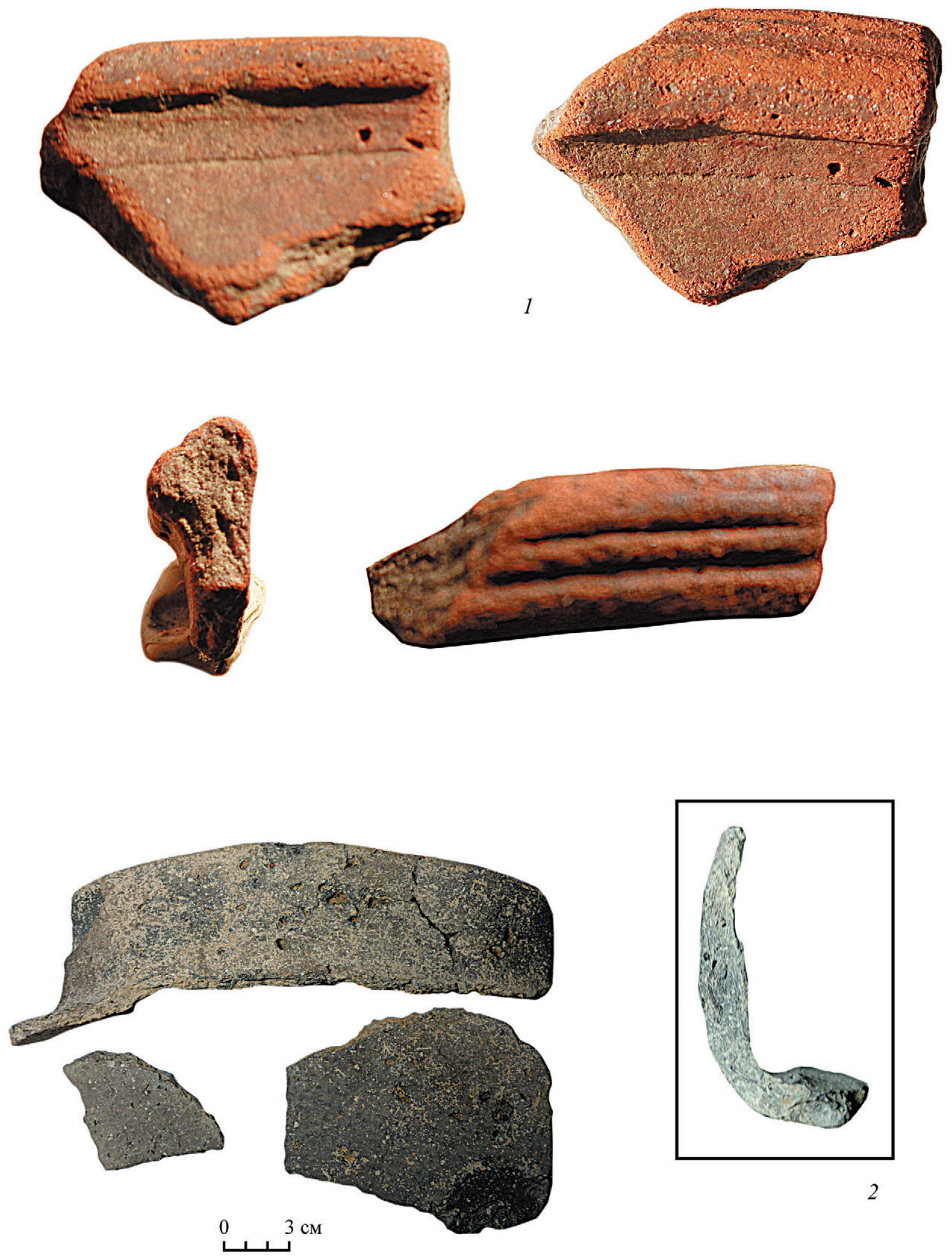

Рис. 63. Раскоп 5. 2014 г. Постройка 4. Находки (крупный план) 5 штык, глубина -113 - -149 см. 

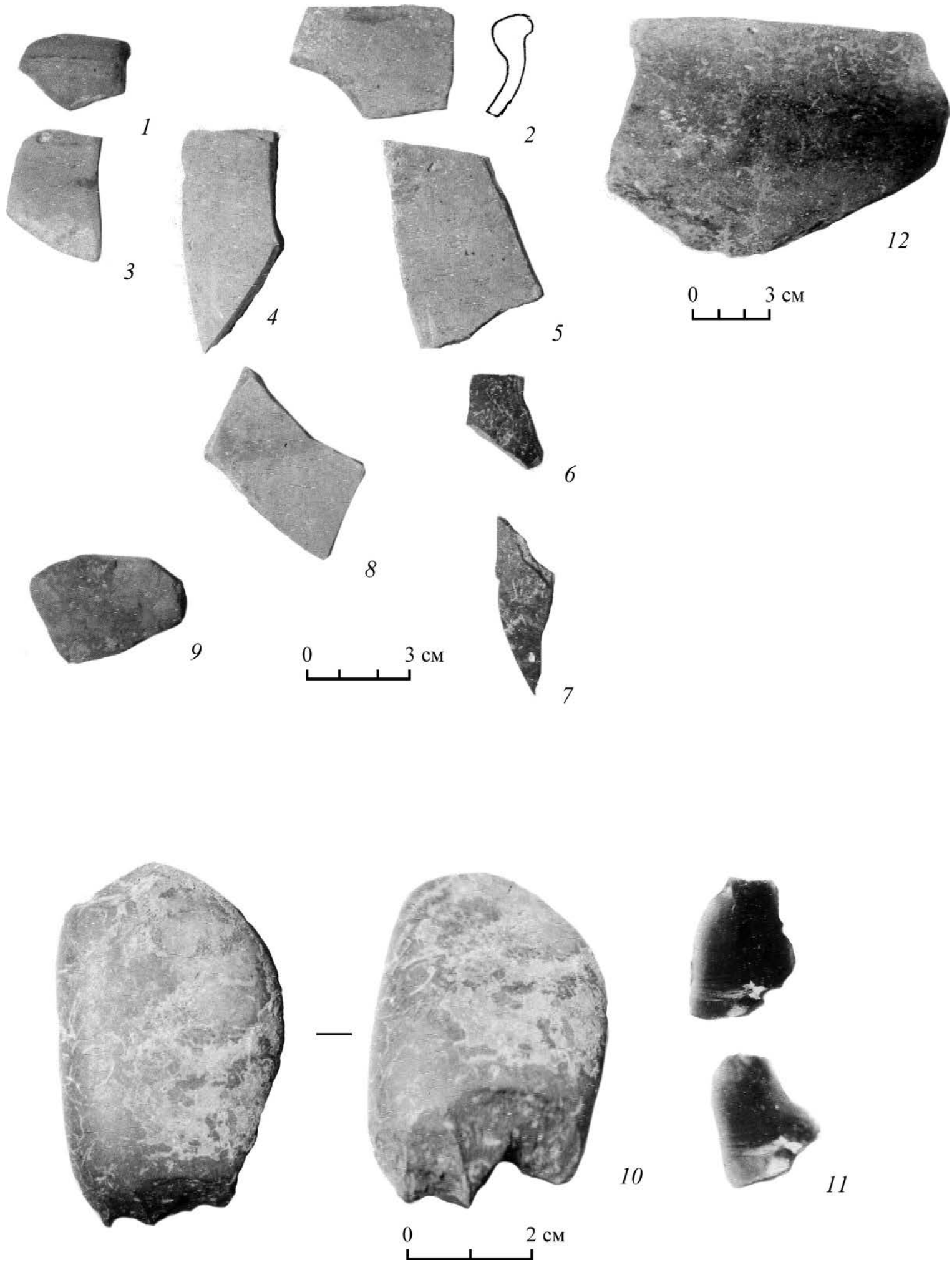

Рис. 64. Раскоп 5. 2014 г. Постройка 4. Находки 5 штык, глубина -113 - -149 см. (Квадрат 1) 1-9- керамика, 10 - каменный отбойник, 11 - скол обсидиана, 12 - керамика 


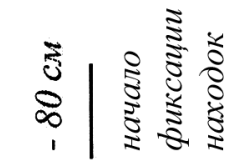

๓

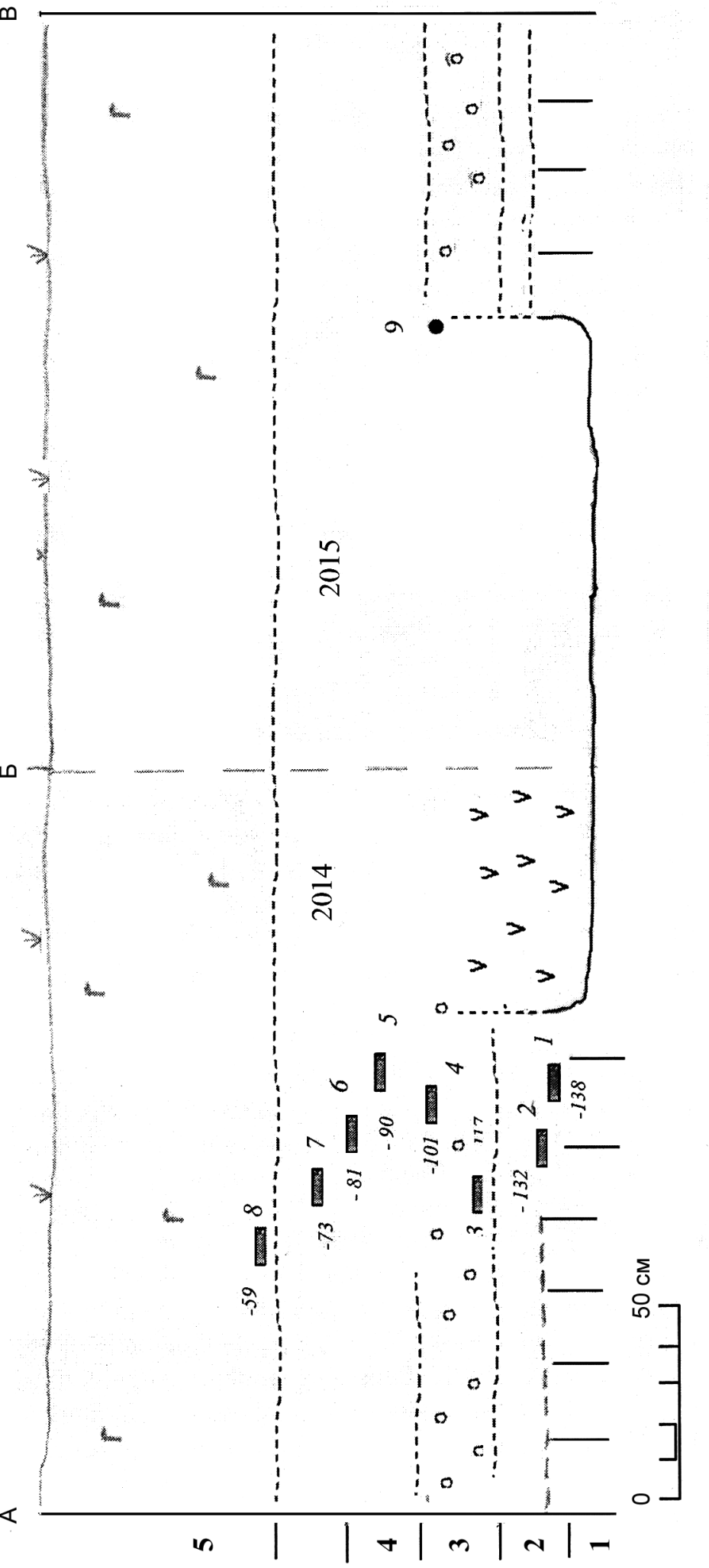

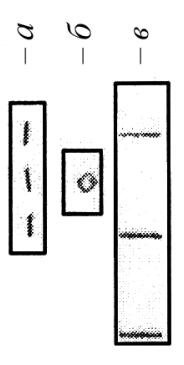

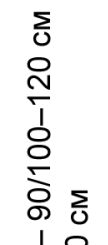

1은

옹 운

온

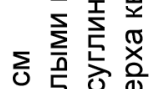

딜

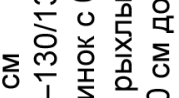

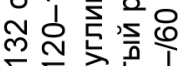

万人

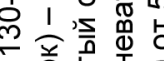

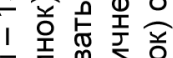

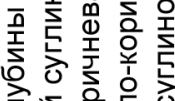

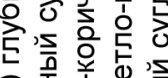

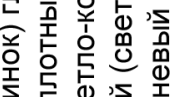

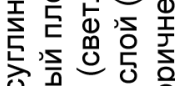

才。商, 응

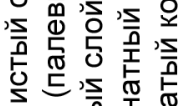

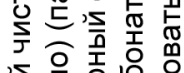

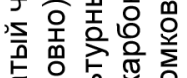

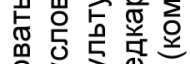

인

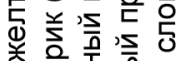

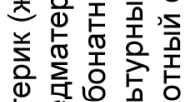

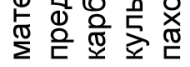

$\begin{array}{llll}2 & 5 & 1 & 1 \\ 1 & 1 & 1 & 1\end{array}$
ํํㅇำ

ॠ

器量

政

है

के 연

$+70$

递安

b

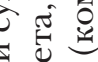

㝵曷

응 층

氙

要

คึ ลิ

可㻤哭

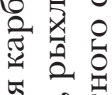

敋

ک

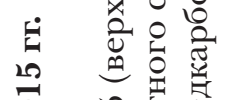

จำ 20 范

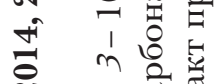

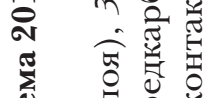

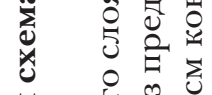

苟

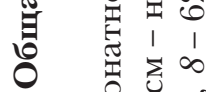

+ $\because \sigma 5$

औis

min

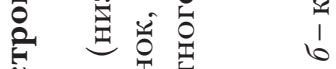

突

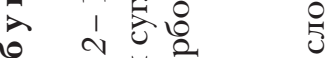

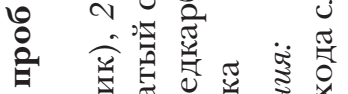

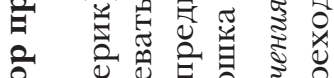

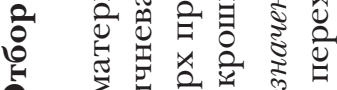

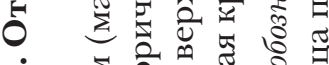

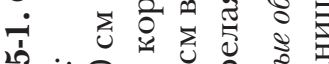

ชิ

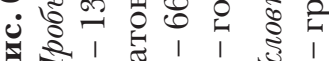



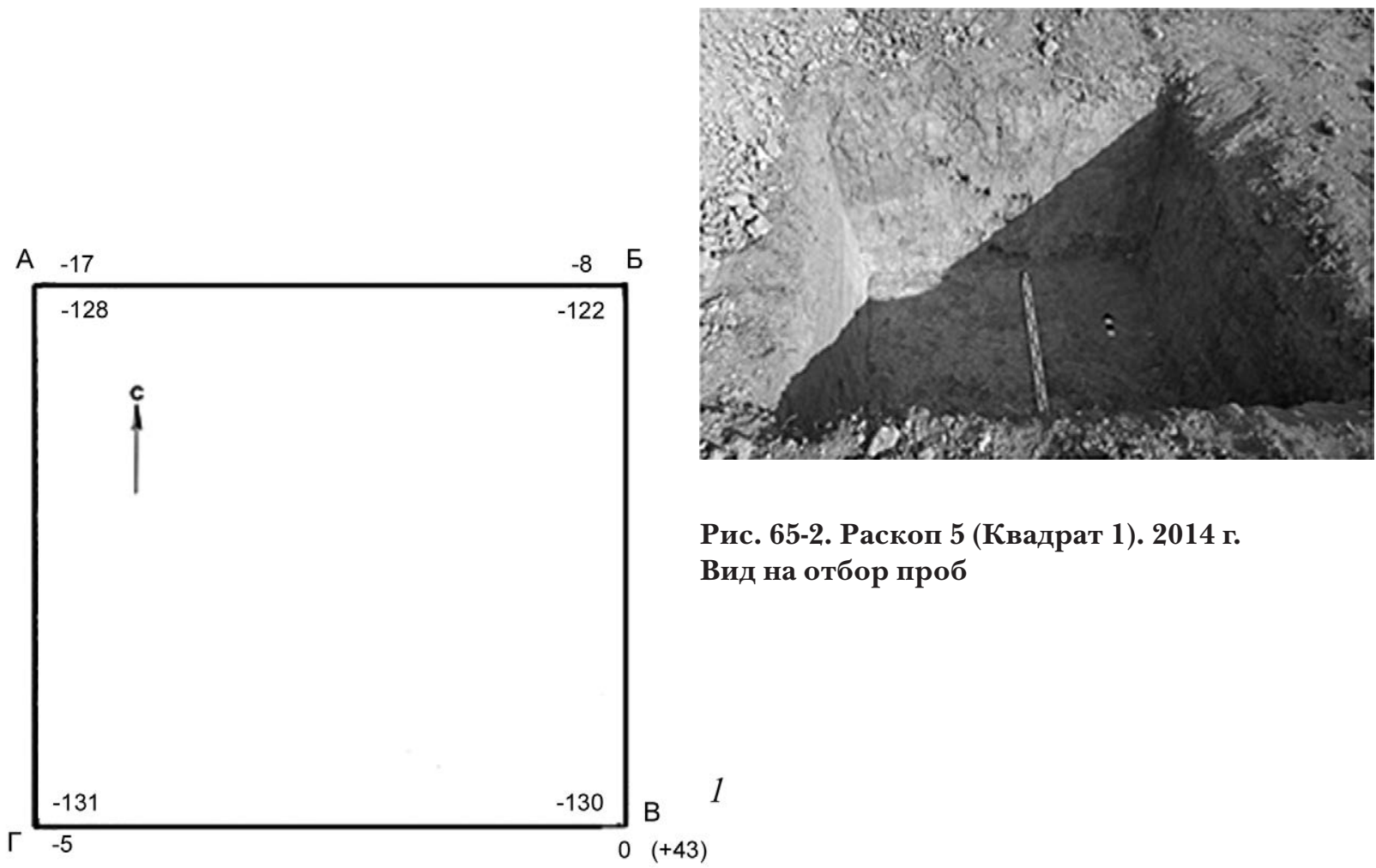

Рис. 65-2. Раскоп 5 (Квадрат 1). 2014 г.

Вид на отбор проб

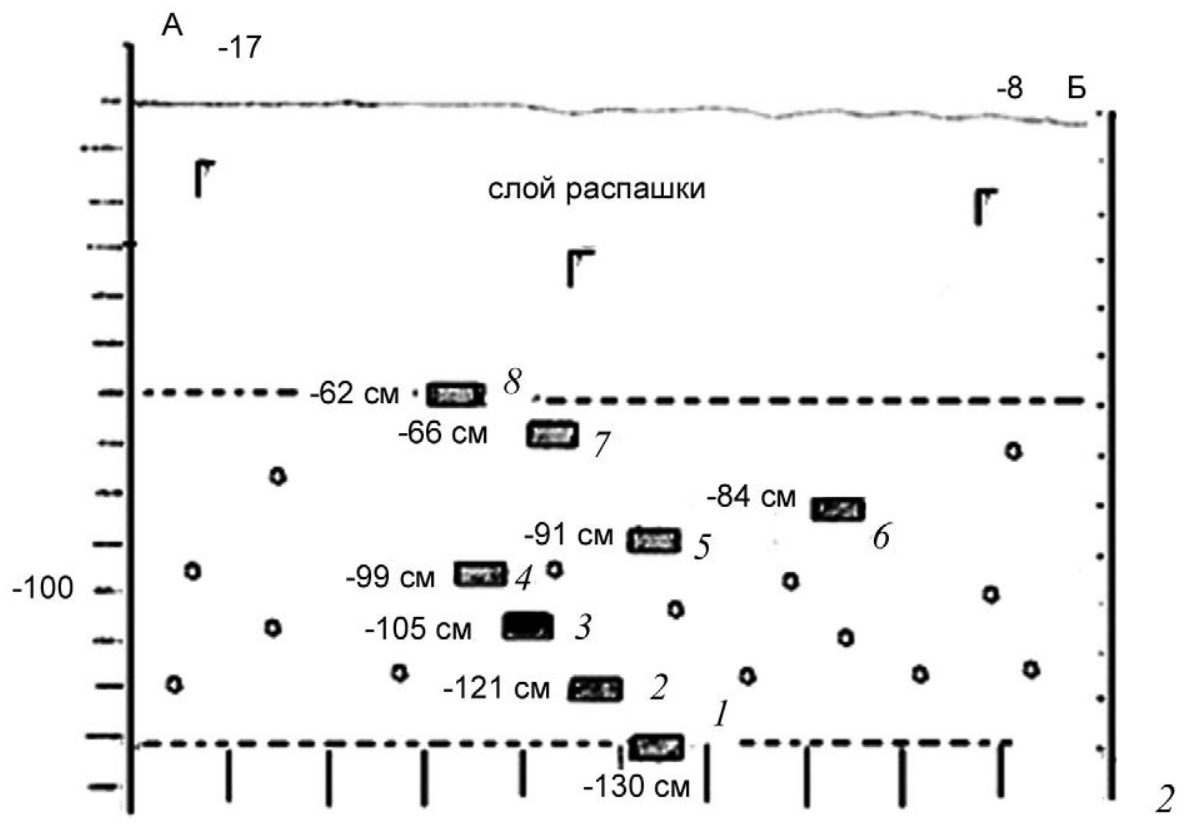

Рис. 66. Раскоп 6. 2014 (Квадрат 2). Отбор проб для палинологического анализа

1 - план раскопа, 2 - колонка проб

На позиции 2: 1 - 130 см. (материк), 2- 121 (низ карбонатного слоя), 3- 105 (верх слоя карбонатов, коричневатый суглинок), 4 - 99 см верх слоя карбонатов, коричневатый суглинок, 5 - 91 см. - низ предкарбонатного слоя, рыхлый грунт палевого цвета, 6- 84 см. предкарбонатный слой, 7 - 66 см верх предкарбонатного слоя, 8-62 см. контакт предкарбонатного слоя и слоя распашки (комковатого коричневого суглинка) 


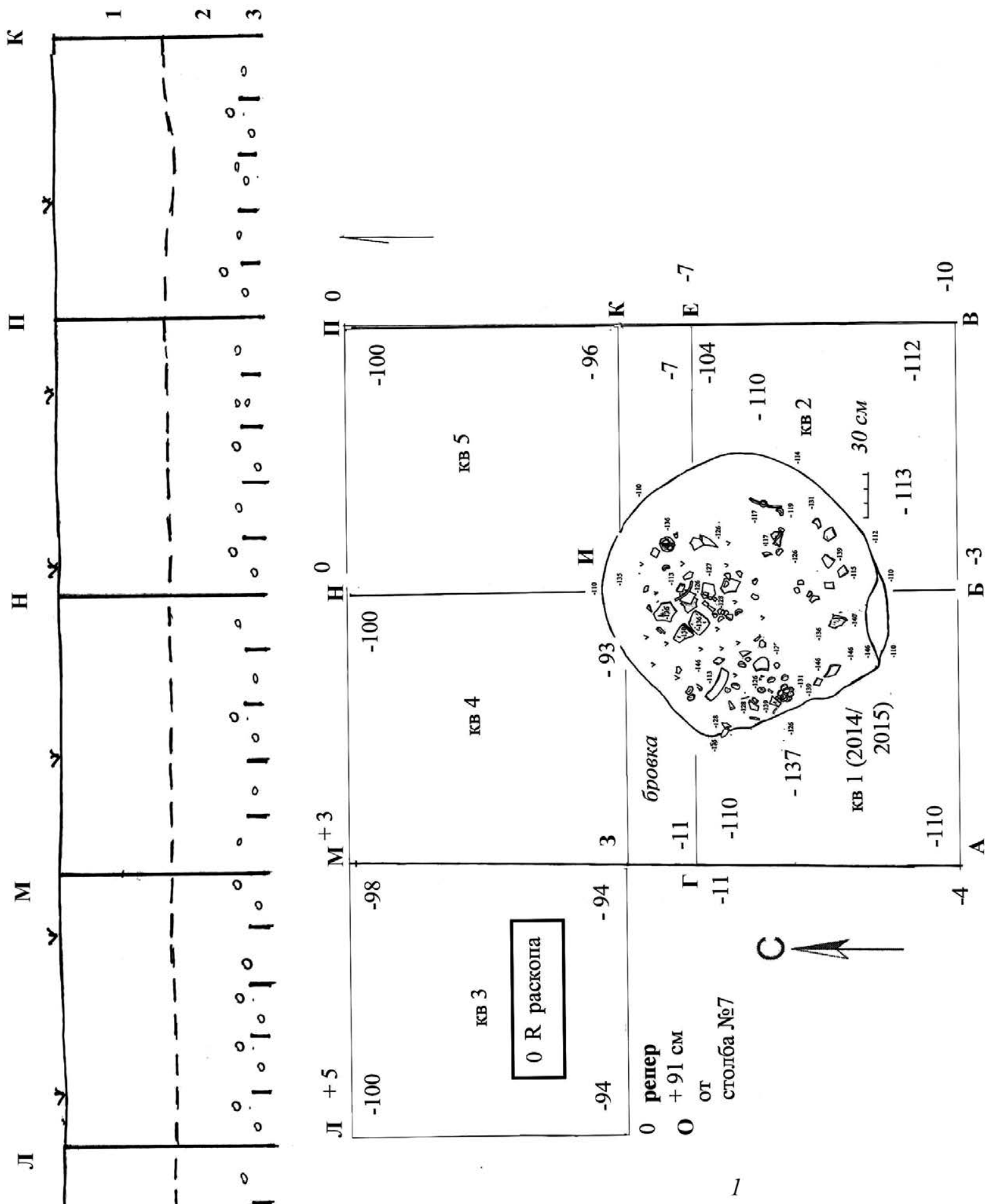

Рис. 67. Раскоп 5. 2015 г. План

(Примечание. Профиль отснят с северного фаса квадратов 3-5, западного фаса квадрата 3 и южного фаса квадрата 5. Остальные фасы квадратов 1, 2 идентичны)

1 - пахотный слой, 2 - надкарбонатный уровень, 3- карбонатный слой 


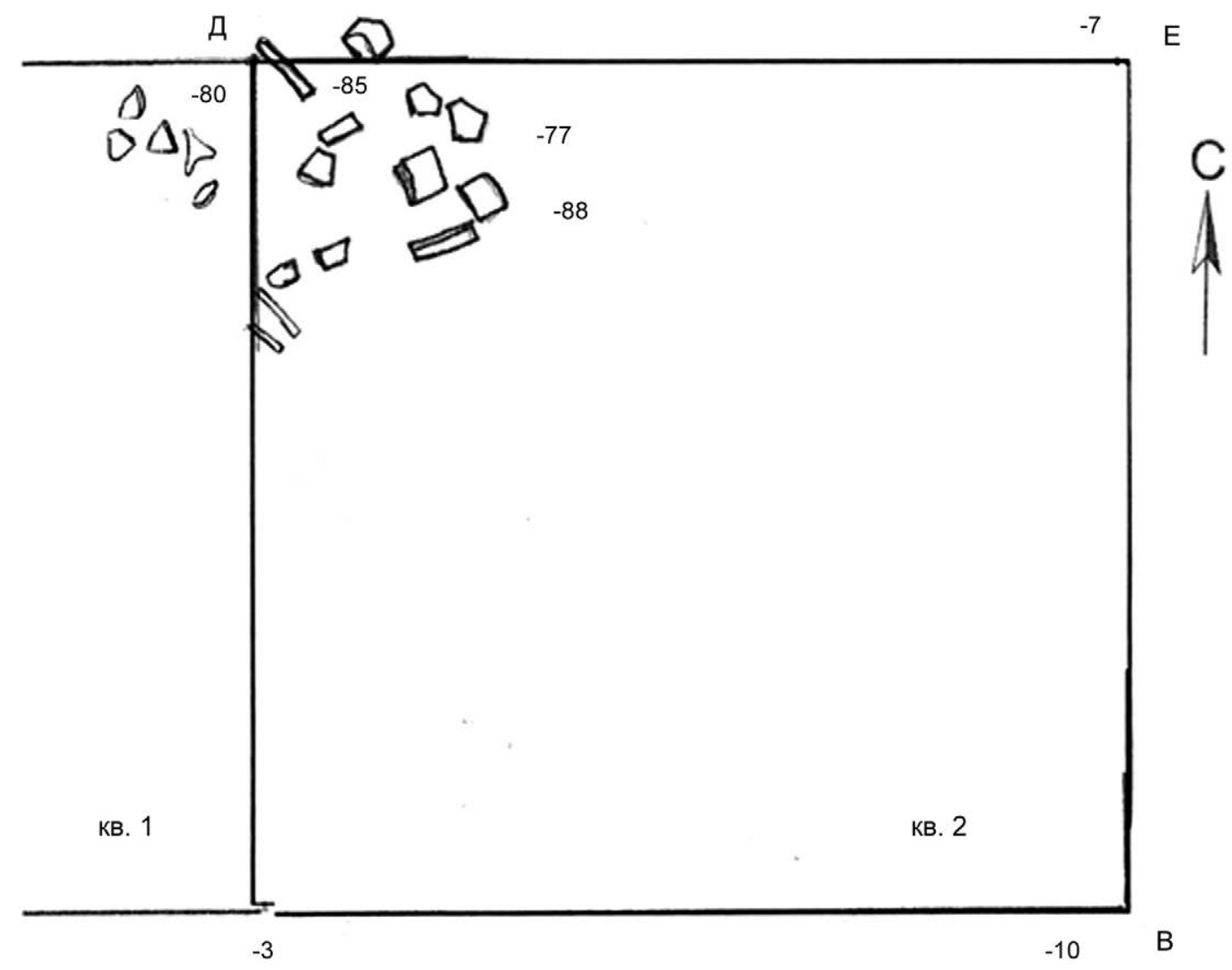

Рис. 68. Раскоп 5. 2015 г. Верхняя яма в квадрате 2, заполненная черепками 

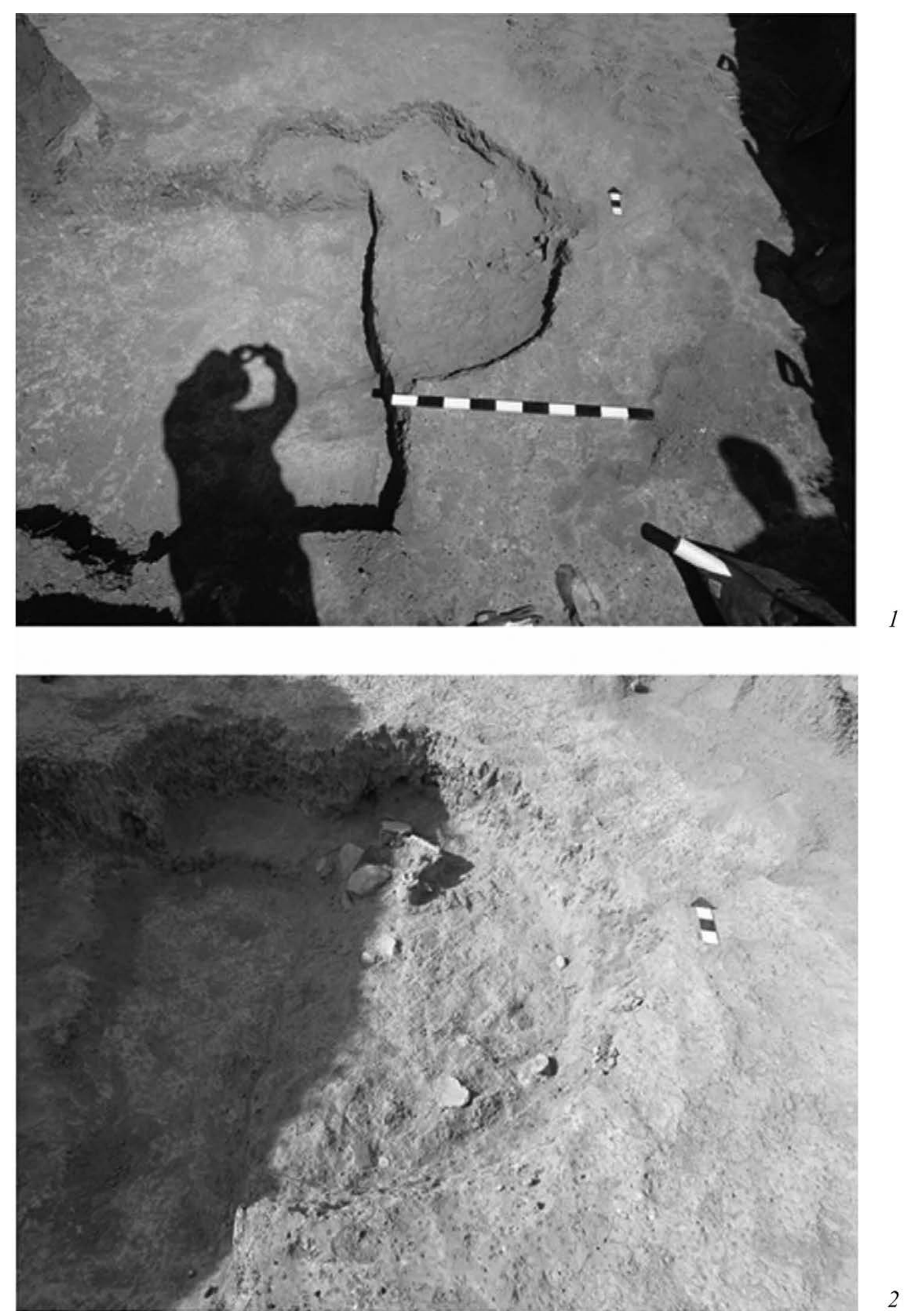

Рис. 69. Раскоп 5. 2015 г. Этапы работ

1 - вид с юга, 2 - вид с юга, крупный план, вид на очаг в постройке 

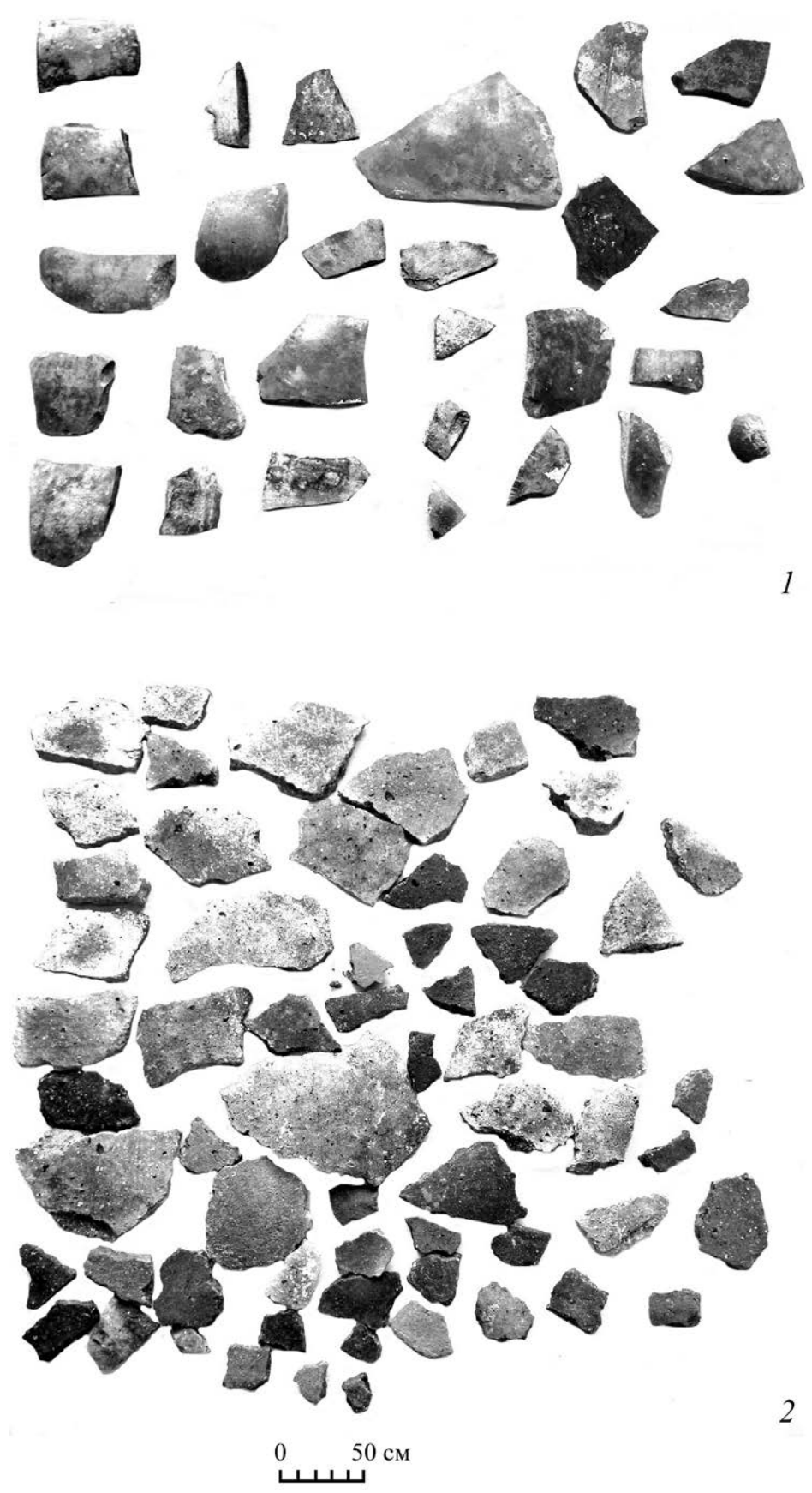

Рис. 70. Раскоп 5. 2015 г. Керамика из постройки 4

1 - керамика 1 класса, 2 - керамика 2 класса 

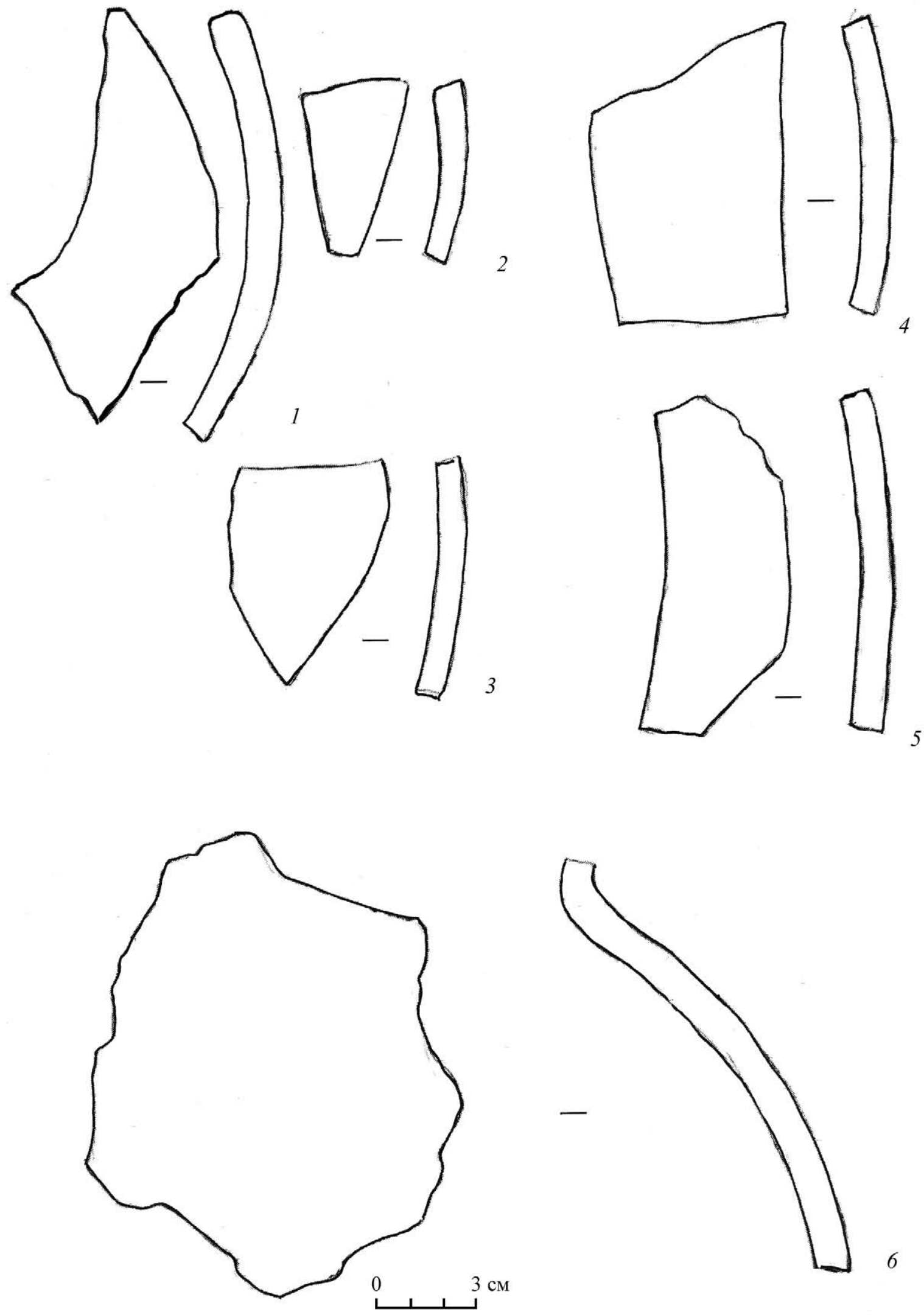

Рис. 71. Раскоп 5. 2015 г. Керамика постройки 4 


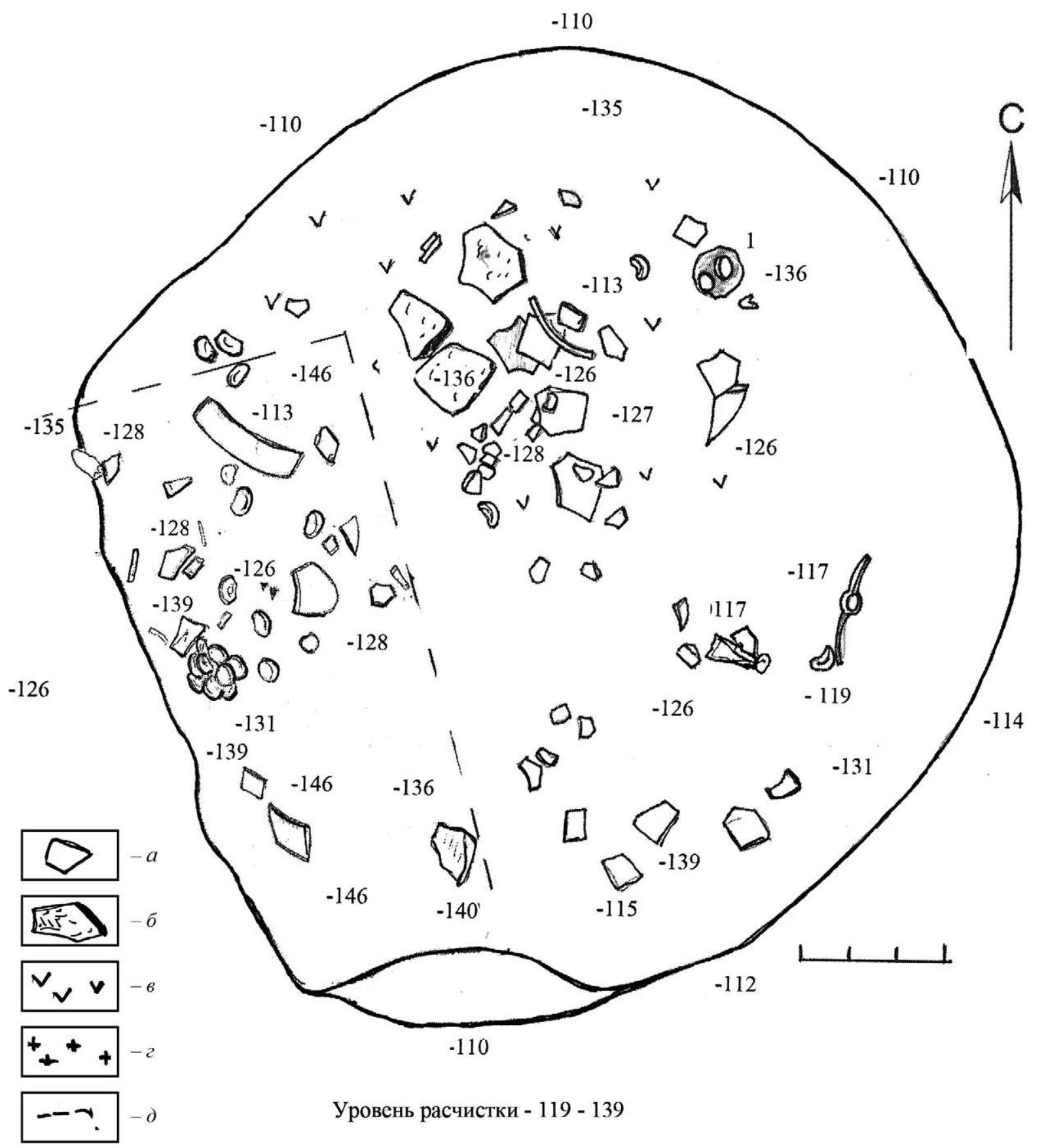

Рис. 72-1. Раскоп 5. 2015 г. Постройка 4. Глубина расчистки -119--139 см

Условнъе обозначения:

$a$ - керамика, б-камни, в-пепел, зола, г-угли, д-граница работы 2014 г. 


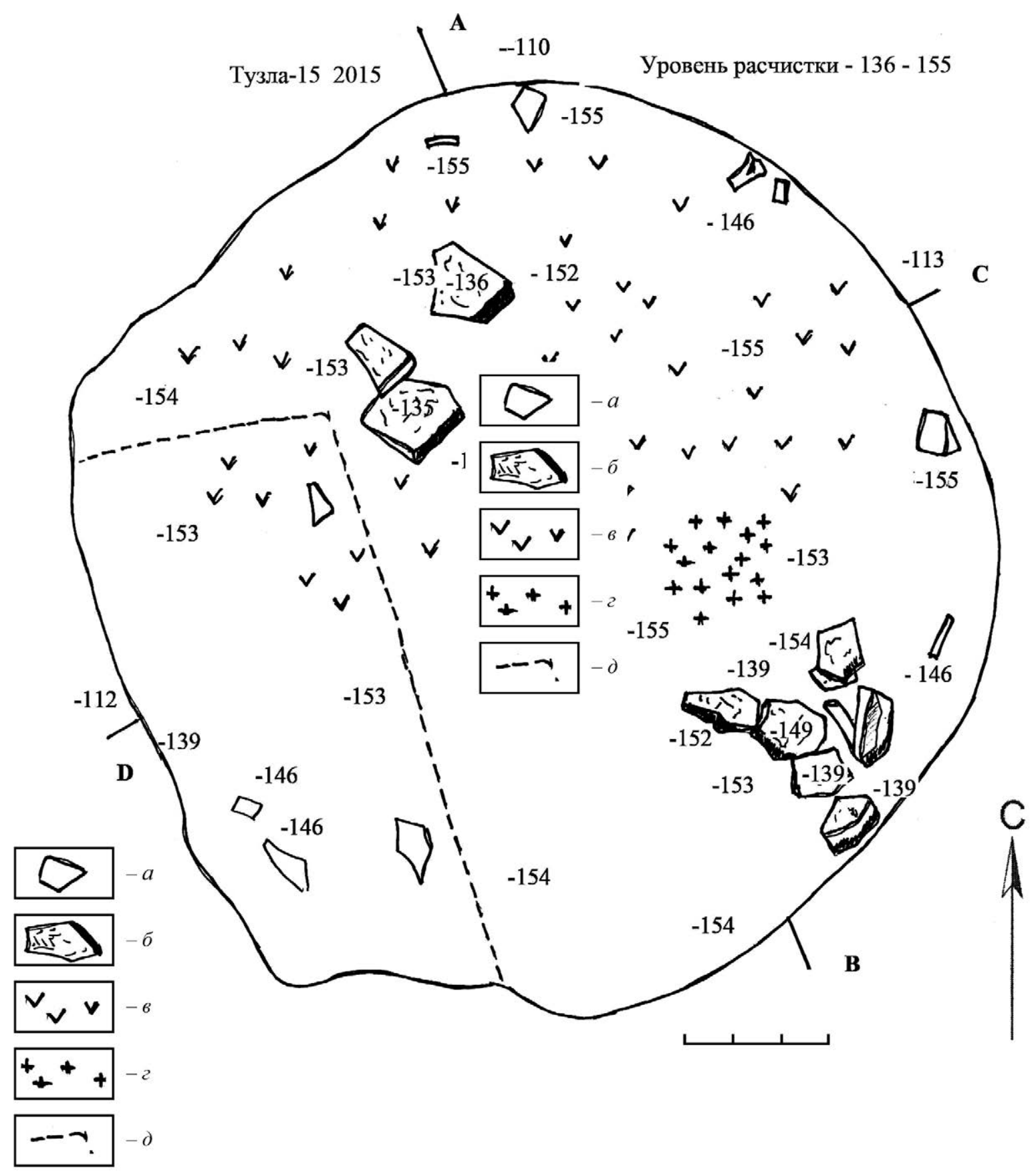

Рис. 72-2. Раскоп 5. 2015 г. Постройка 4 . Камни на дне постройки, прокал с углями и зола в заполнении 

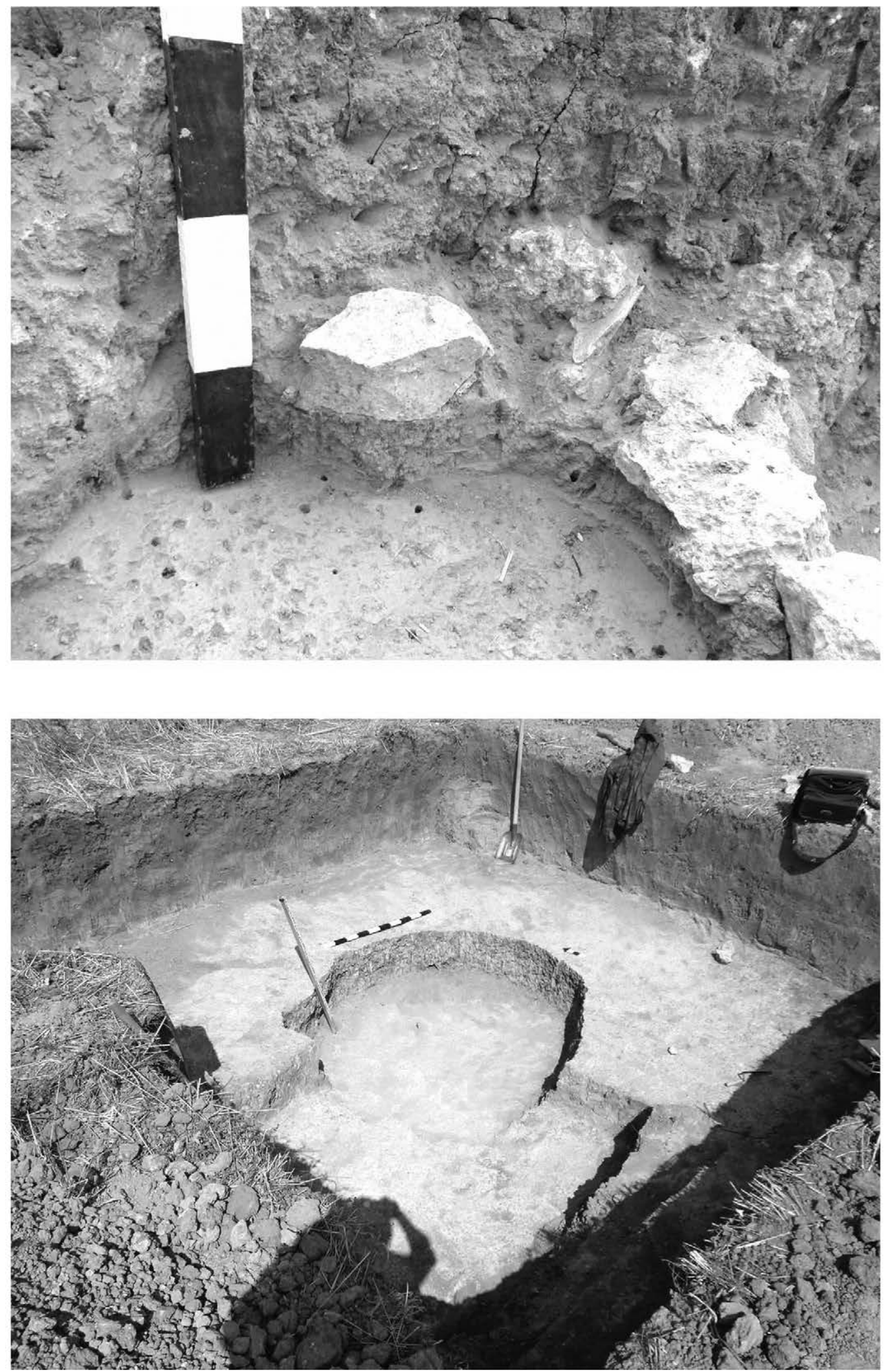

\section{Рис. 73. Раскоп 5. 2015 г. Фрагменты работ}

1 - каменная кладка у дна сооружения. Вид с северо-востока, 2 - вид на контуры строения при полной расчистке по дну 


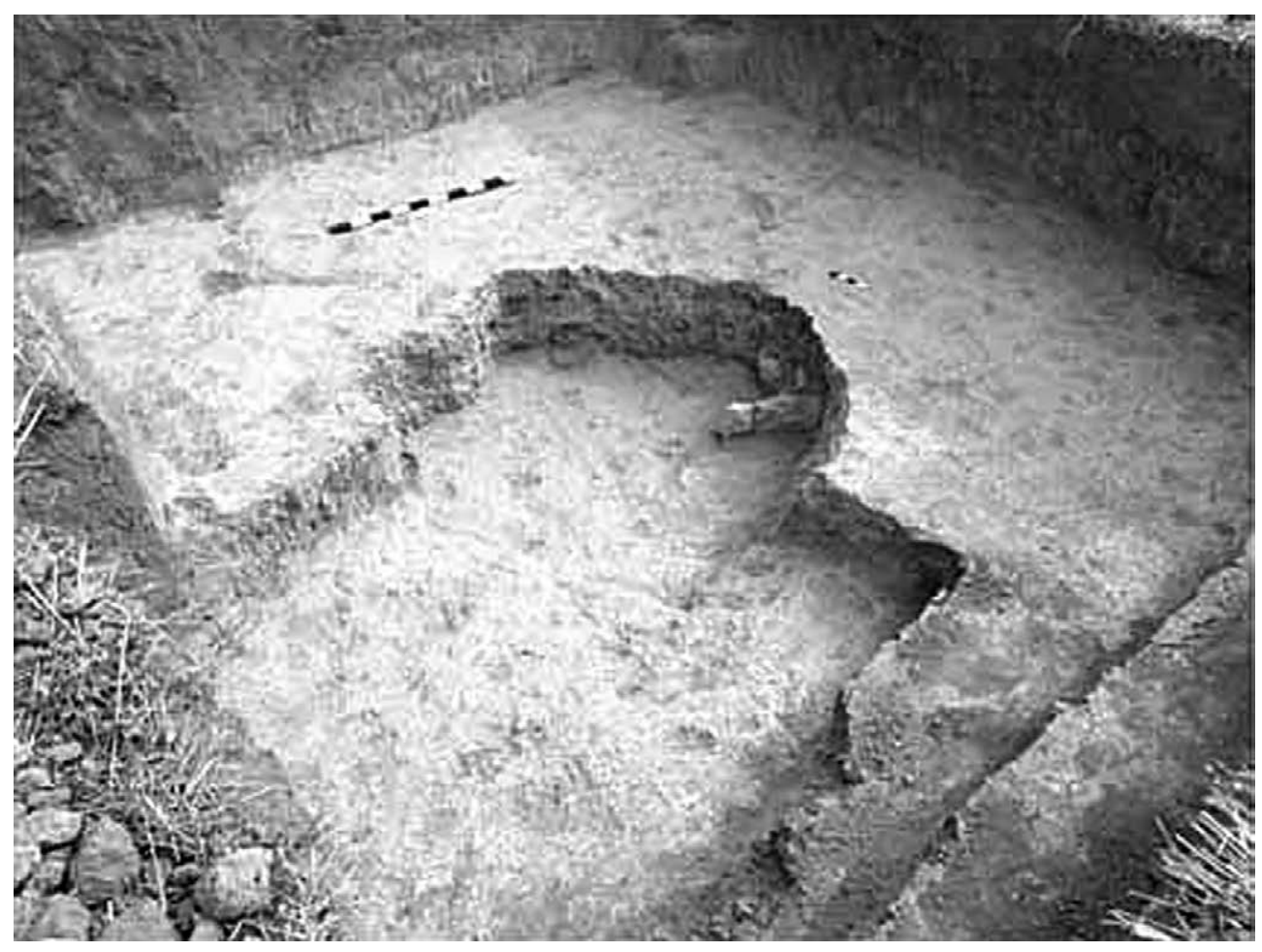

Рис. 74. Раскоп 5. 2015 год. Вид на постройку 4 с кладкой камней с юго-запада

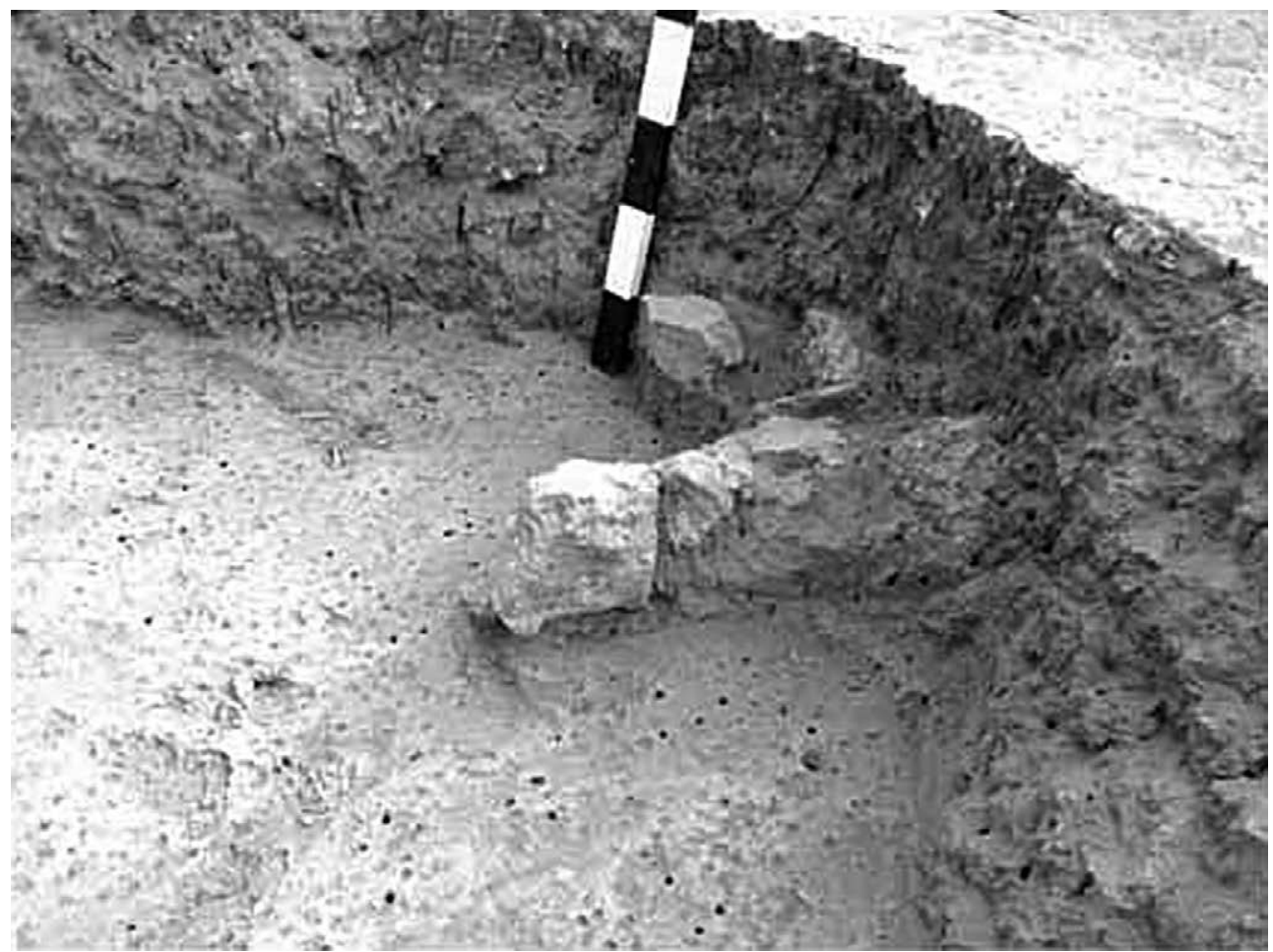

Рис. 75. Раскоп 5. 2015 г. Постройка 4. Кладка камней 
A
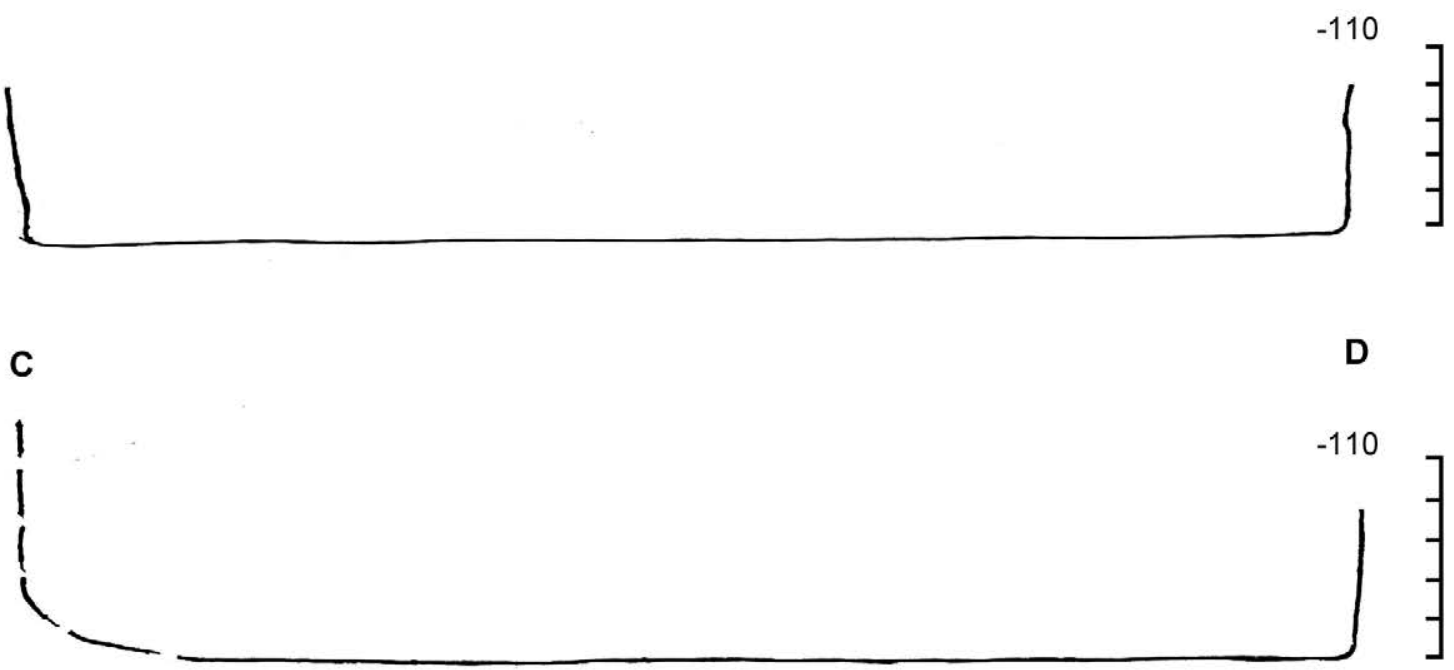

D

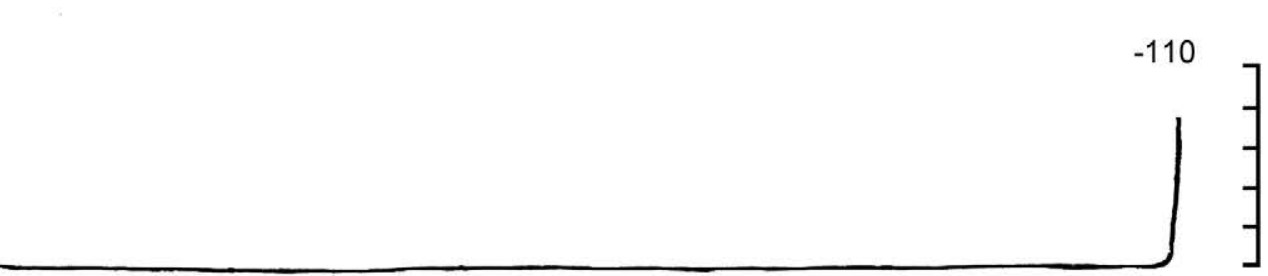

3

K
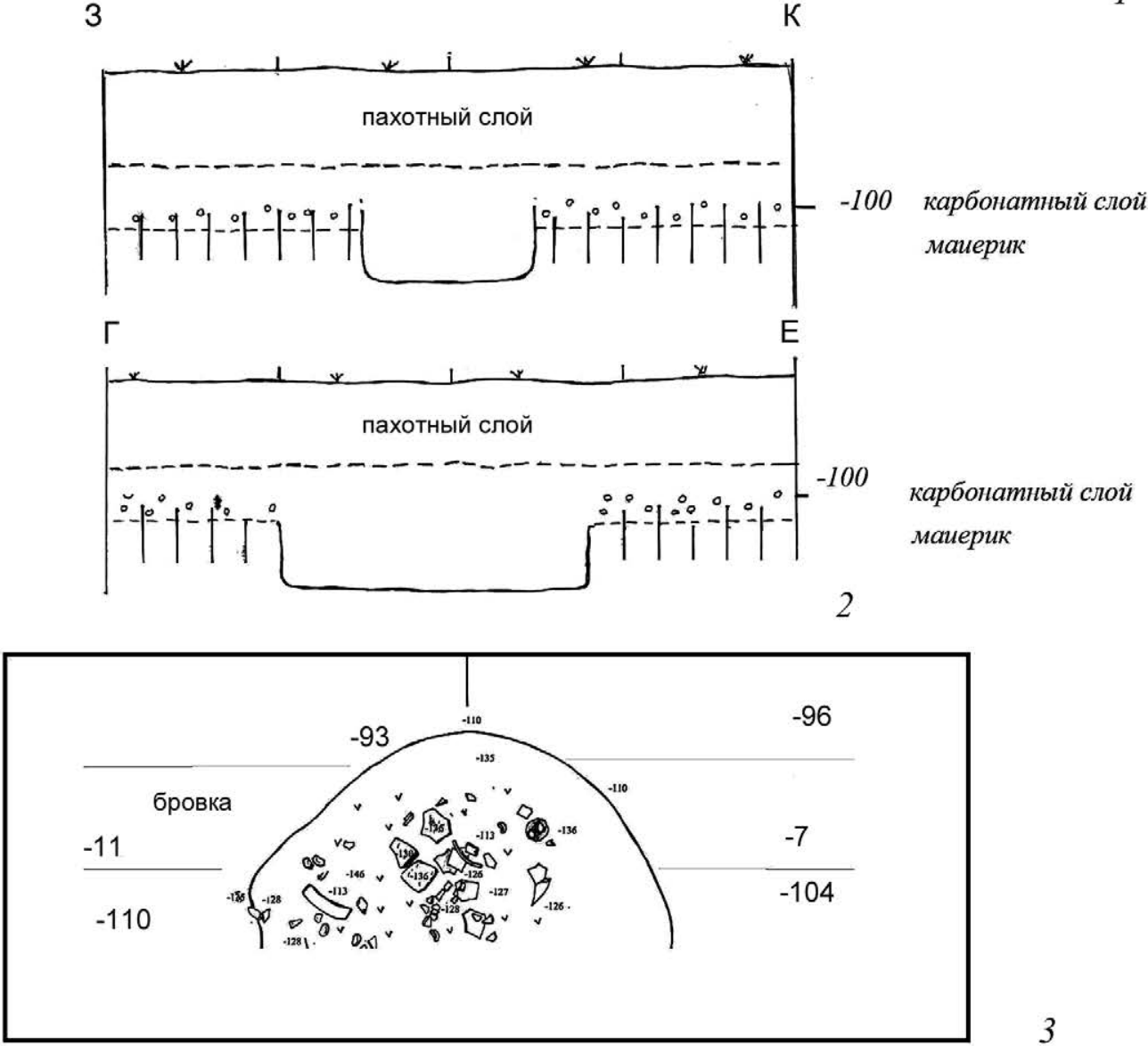

Рис. 76. Раскоп 5. 2015 г. Постройка 4. План и разрезы

1 - разрезы постройки по осям AB-CD, 2- разрезы ямы в бровке, 3 - план разрезов в бровке 

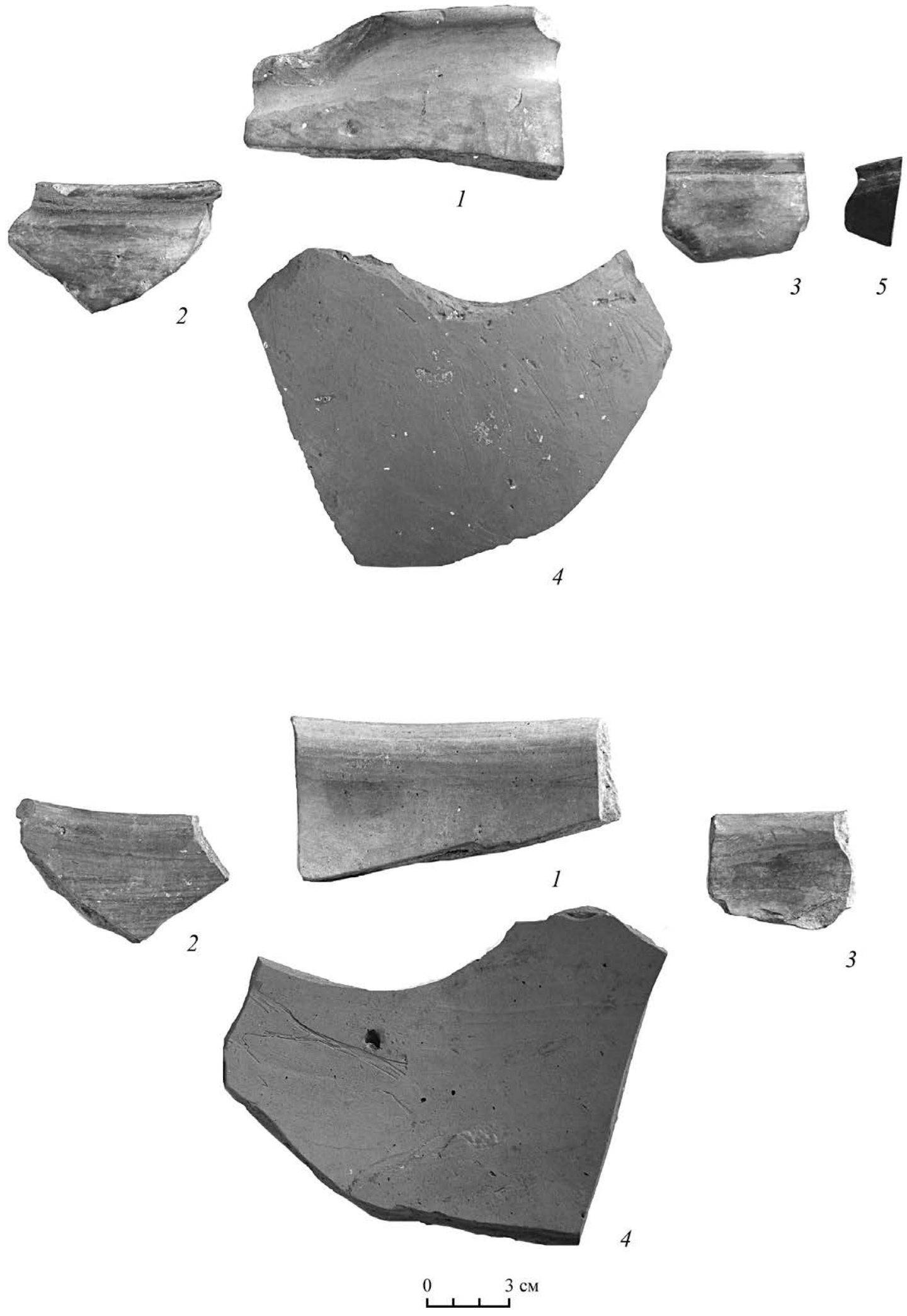

Рис. 77. Раскоп 5. 2015 г. Постройка 4. Керамика 1 класса

1-4- охристые тона, 5- черный цвет 

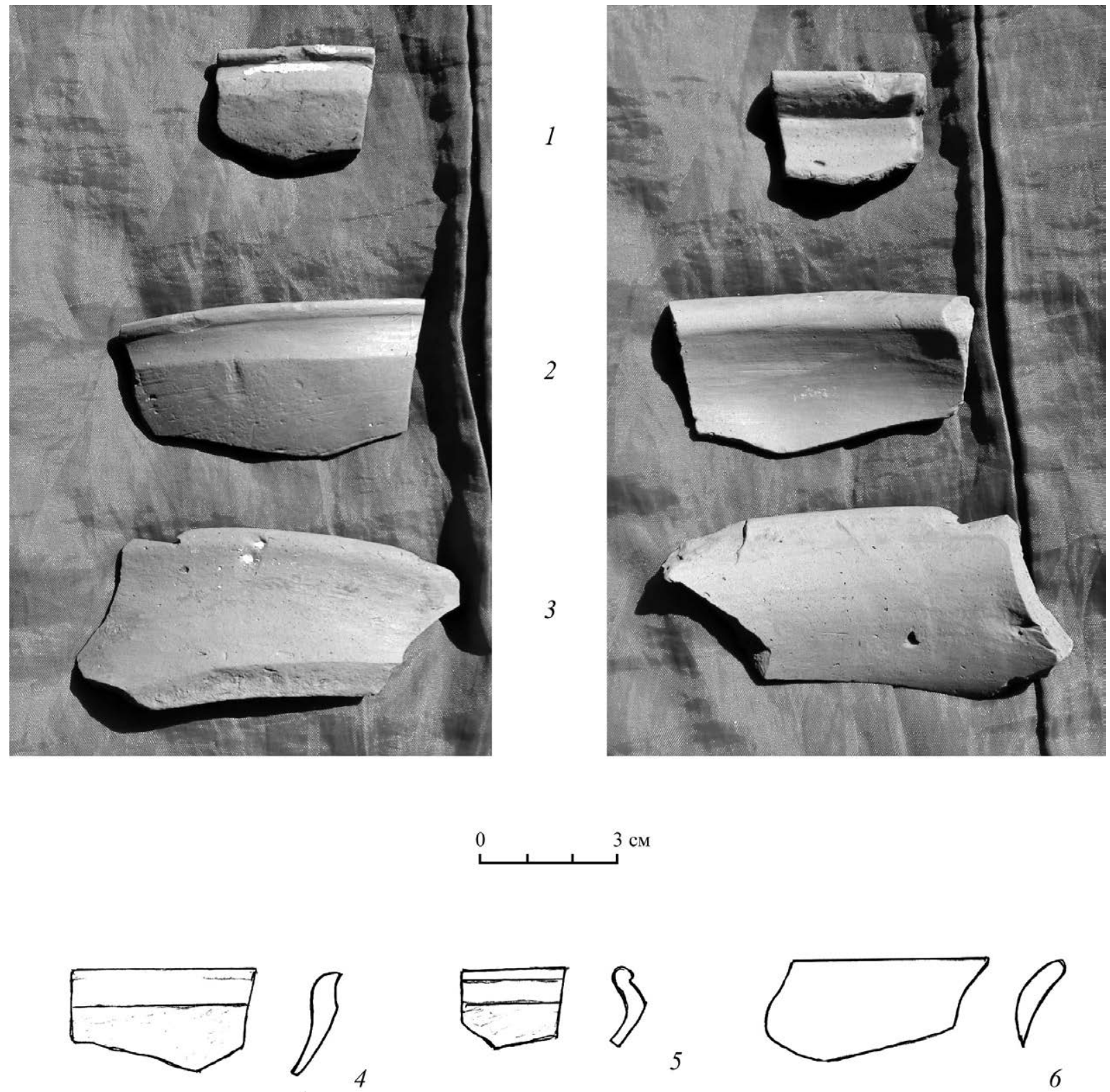

Рис. 78. Раскоп 5. 2015 г. Керамика 1 класса 

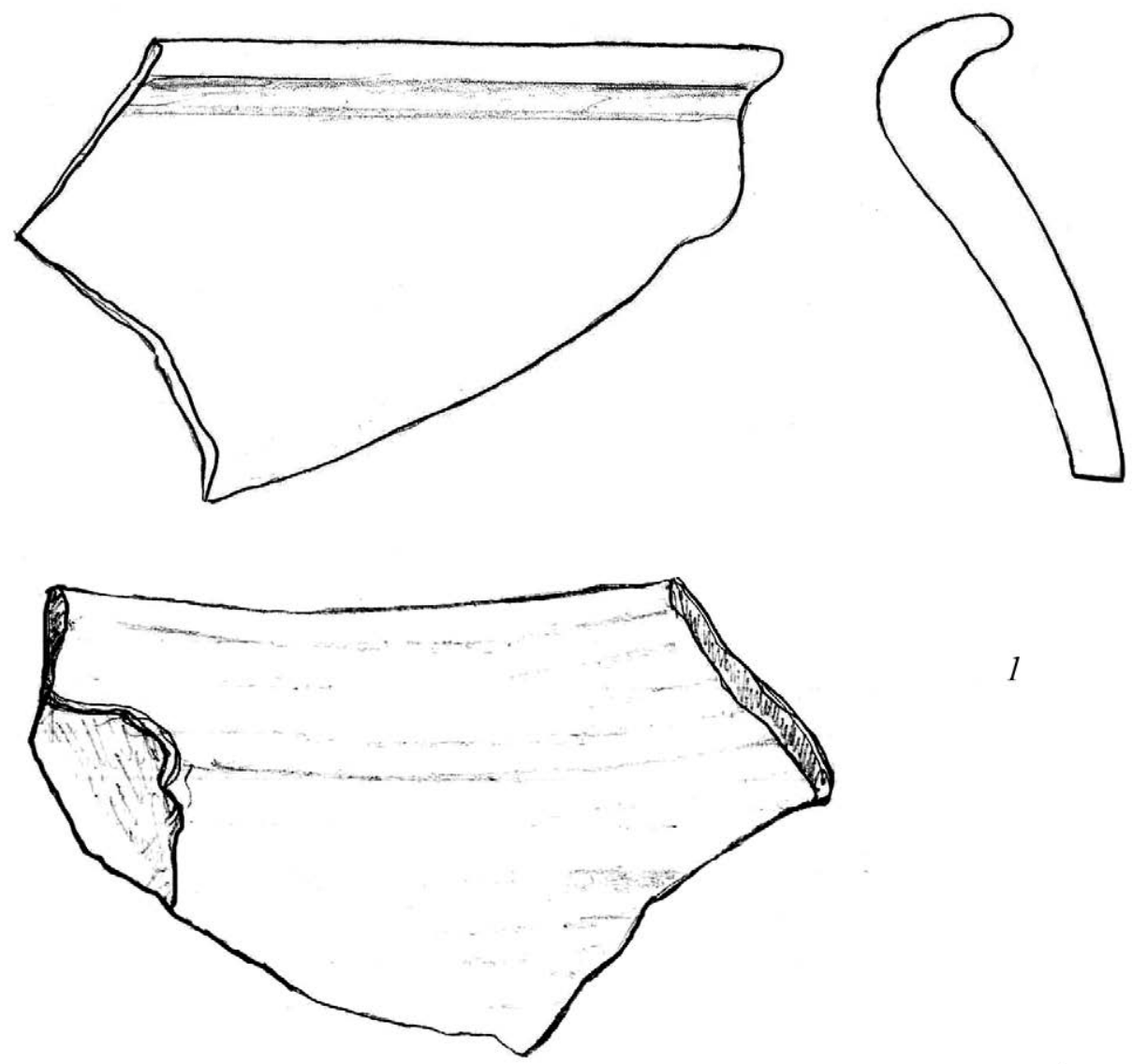

1

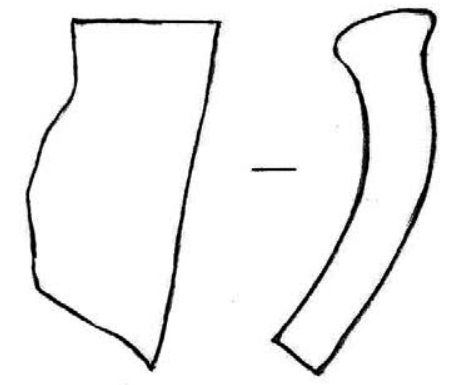

2

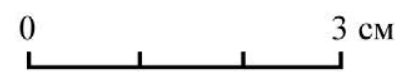

Рис. 79. Раскоп 5. 2015 г. Керамика со следами окрашивания 


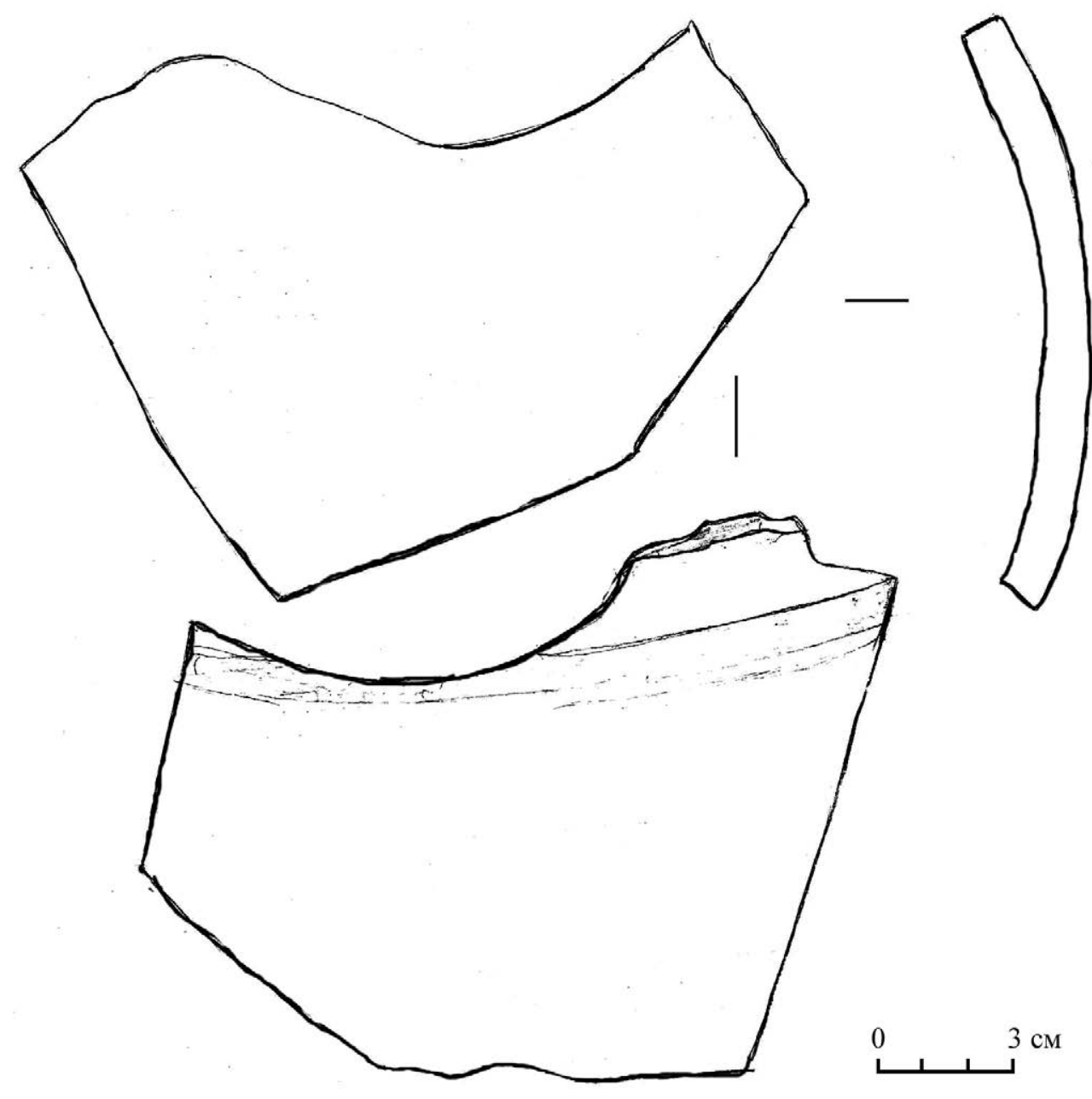

Рис. 80. Раскоп 5. 2015 г. Фрагмент крашеной керамики 

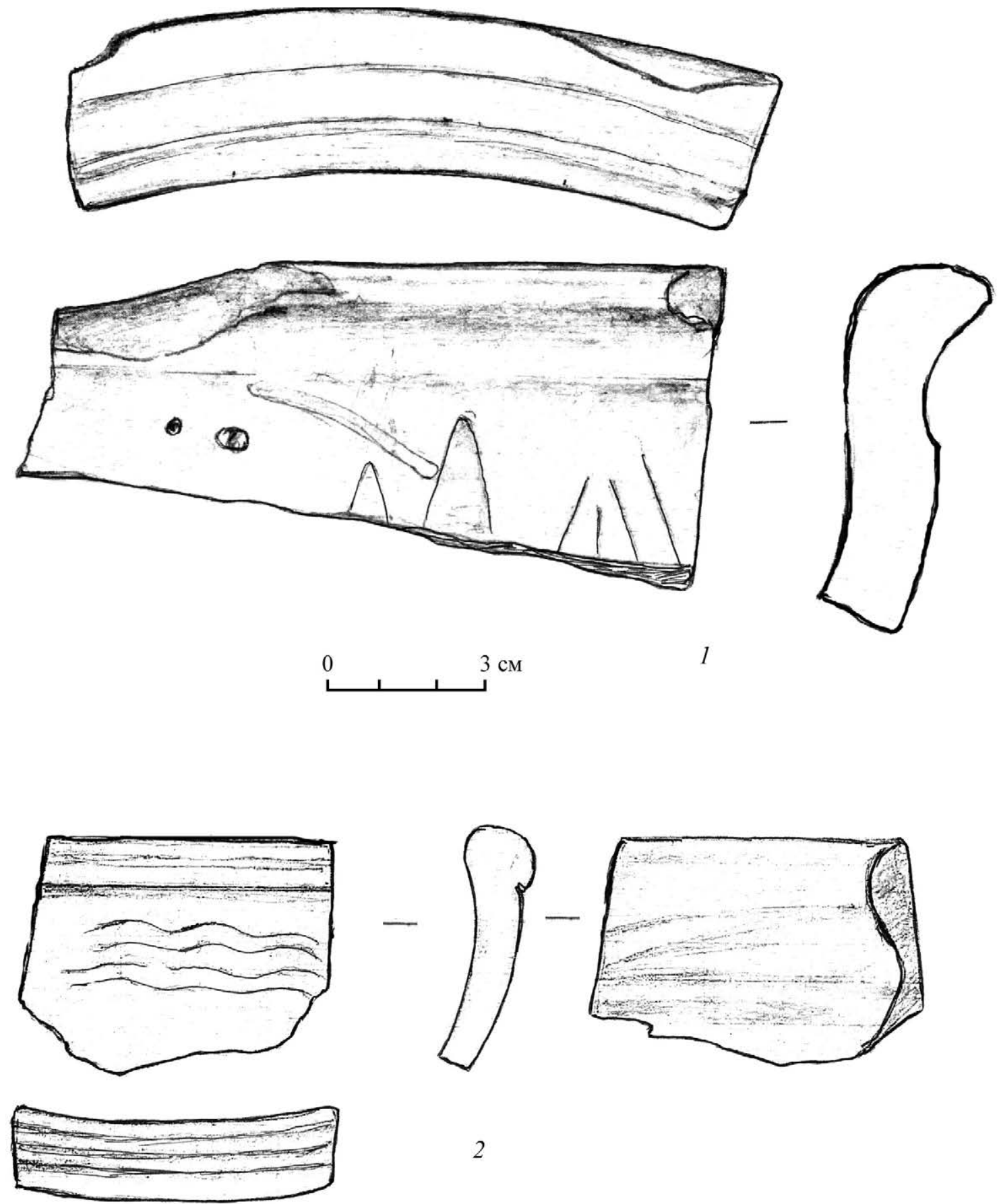

2

Рис. 81. Раскоп 5. 2015 г. Керамика со следами окрашивания 

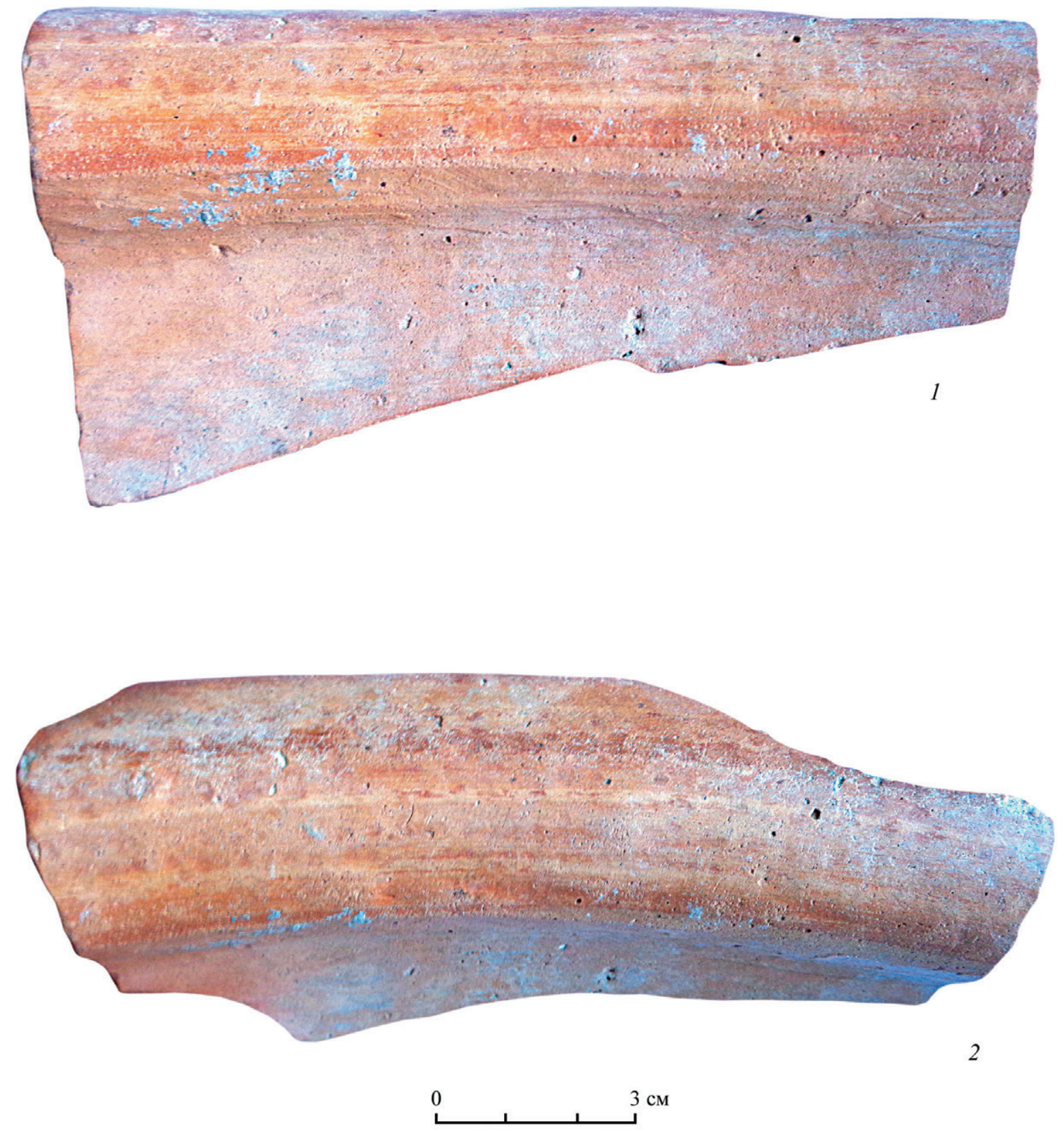

Рис. 82. Раскоп 5. 2015 г. Керамика со следами окрашивания 

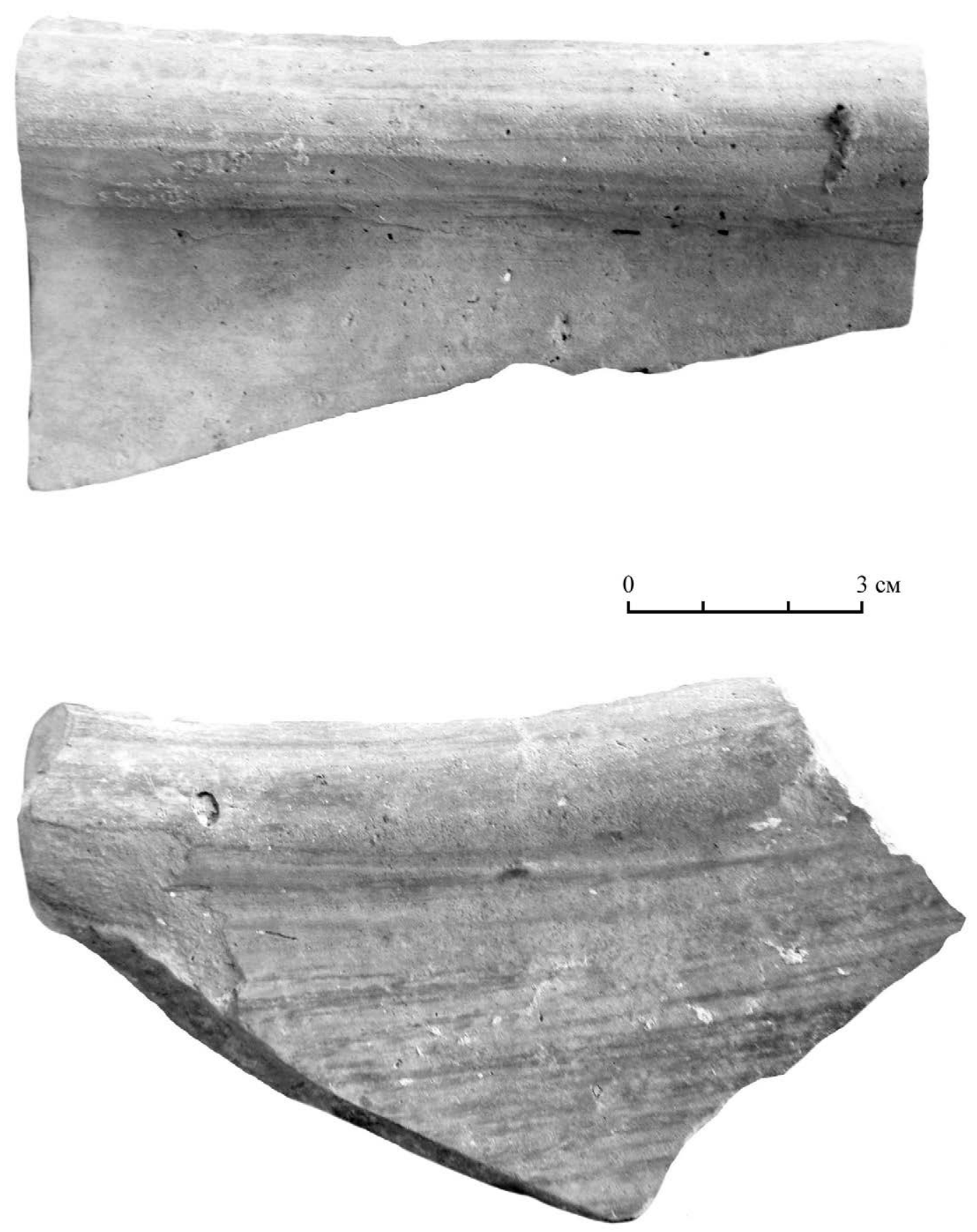

Рис. 83. Раскоп 5. 2015 г. Керамика со следами окрашивания 

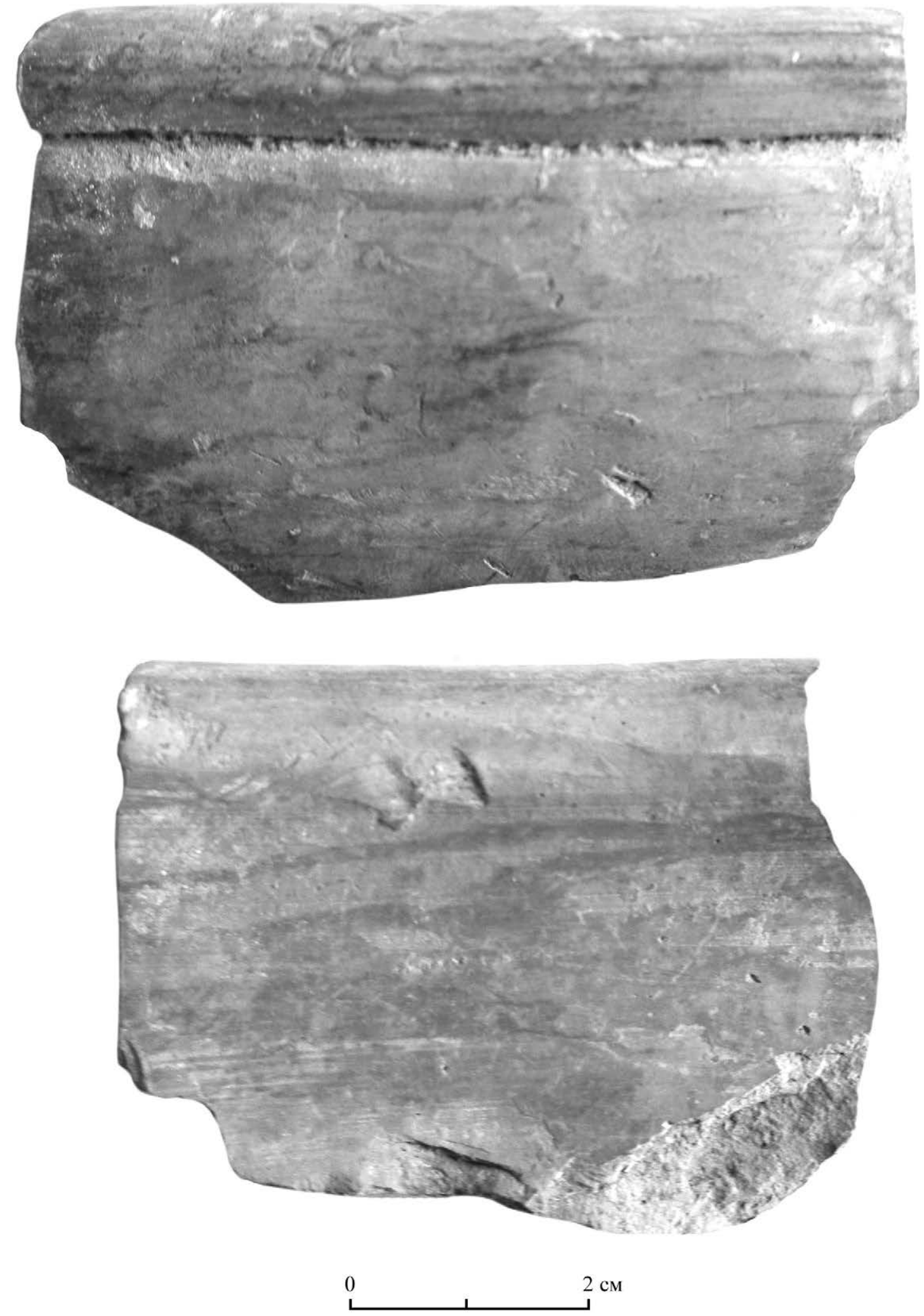

Рис. 84. Раскоп 5. 2015 г. Керамика со следами окрашивания 

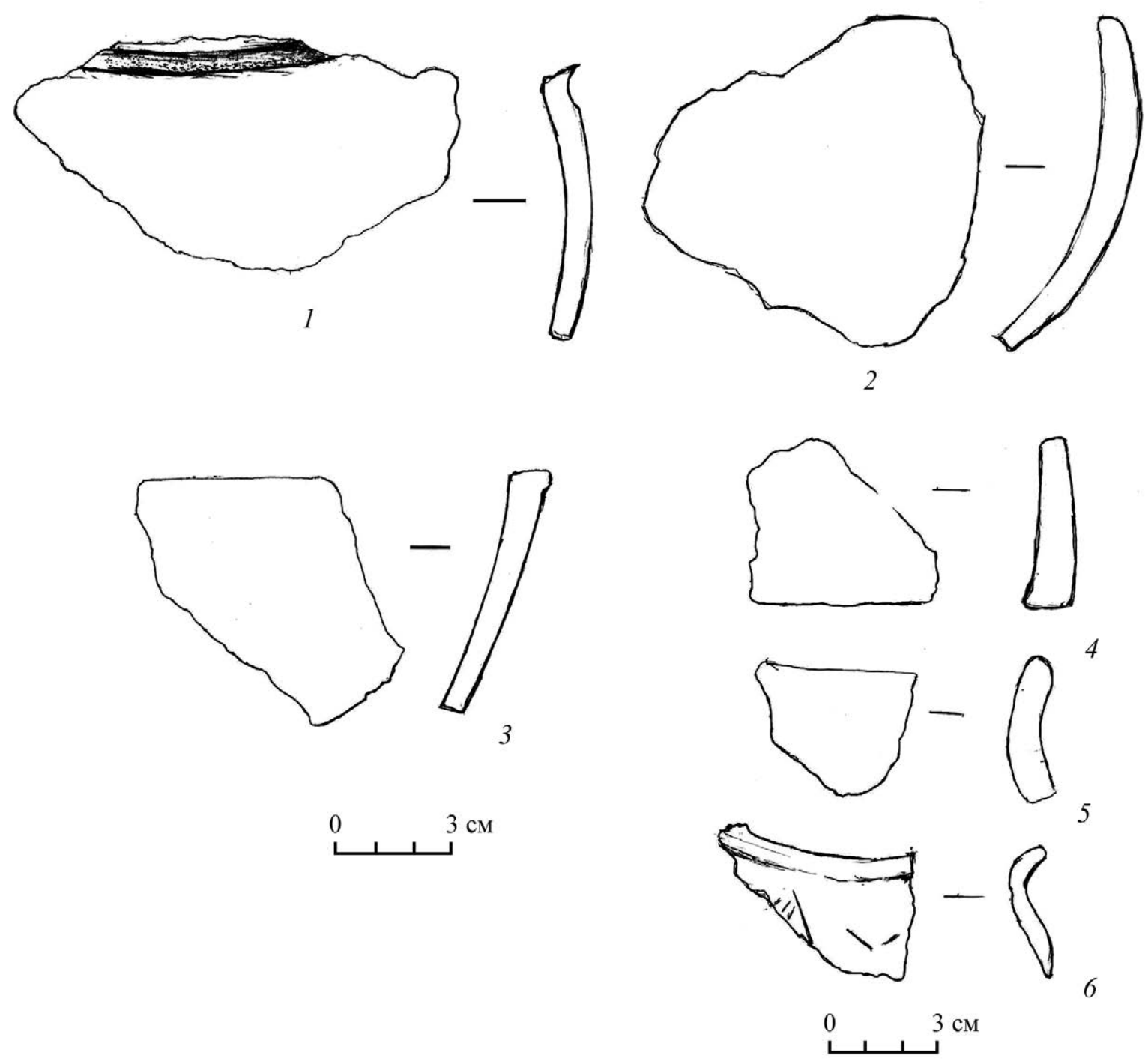

Рис. 85. Раскоп 5. 2015 г. Керамика с искусственными минеральными примесями 2 класса 

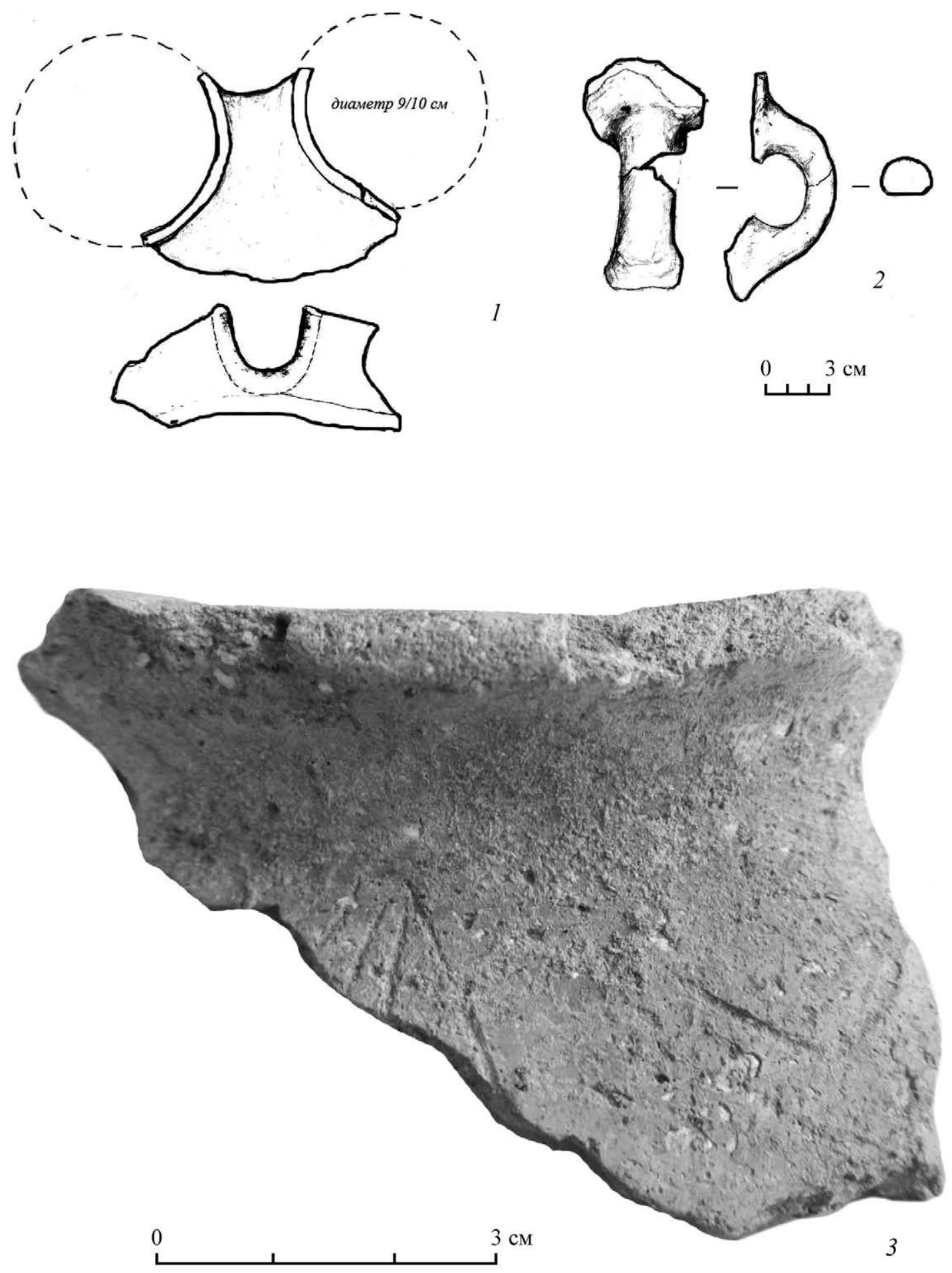

Рис. 86. Раскоп 5. 2015 г. Керамика с минеральными примесями 

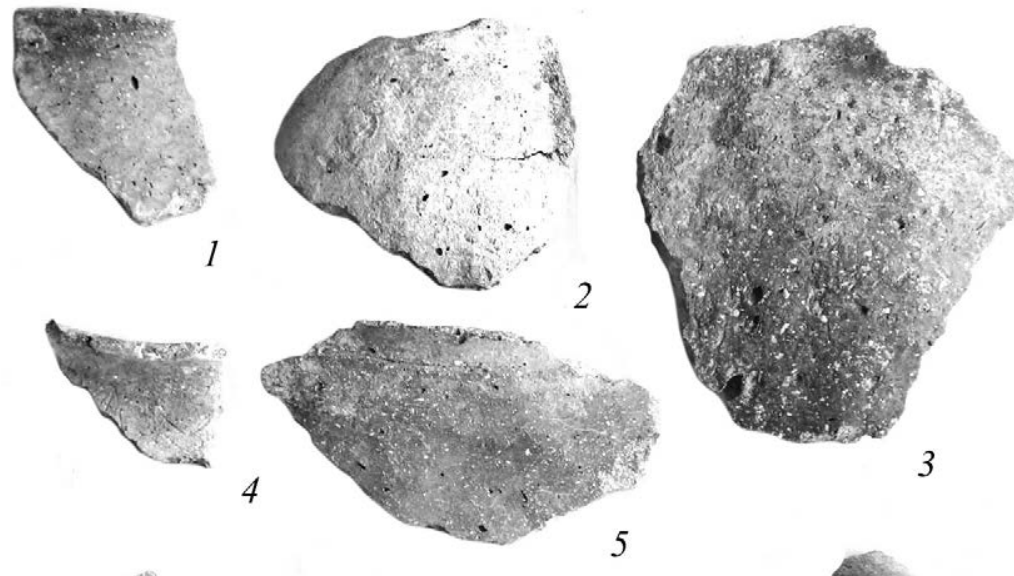

3

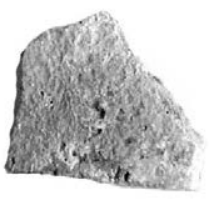

6
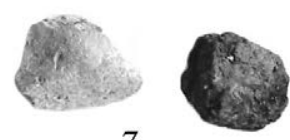

7

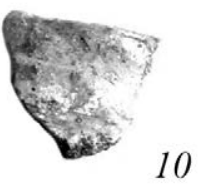

8

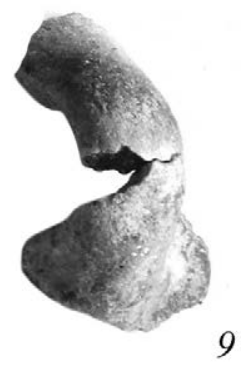

10

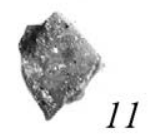

Рис. 87. Раскоп 5. 2015 г. Керамика с минеральными примесями 

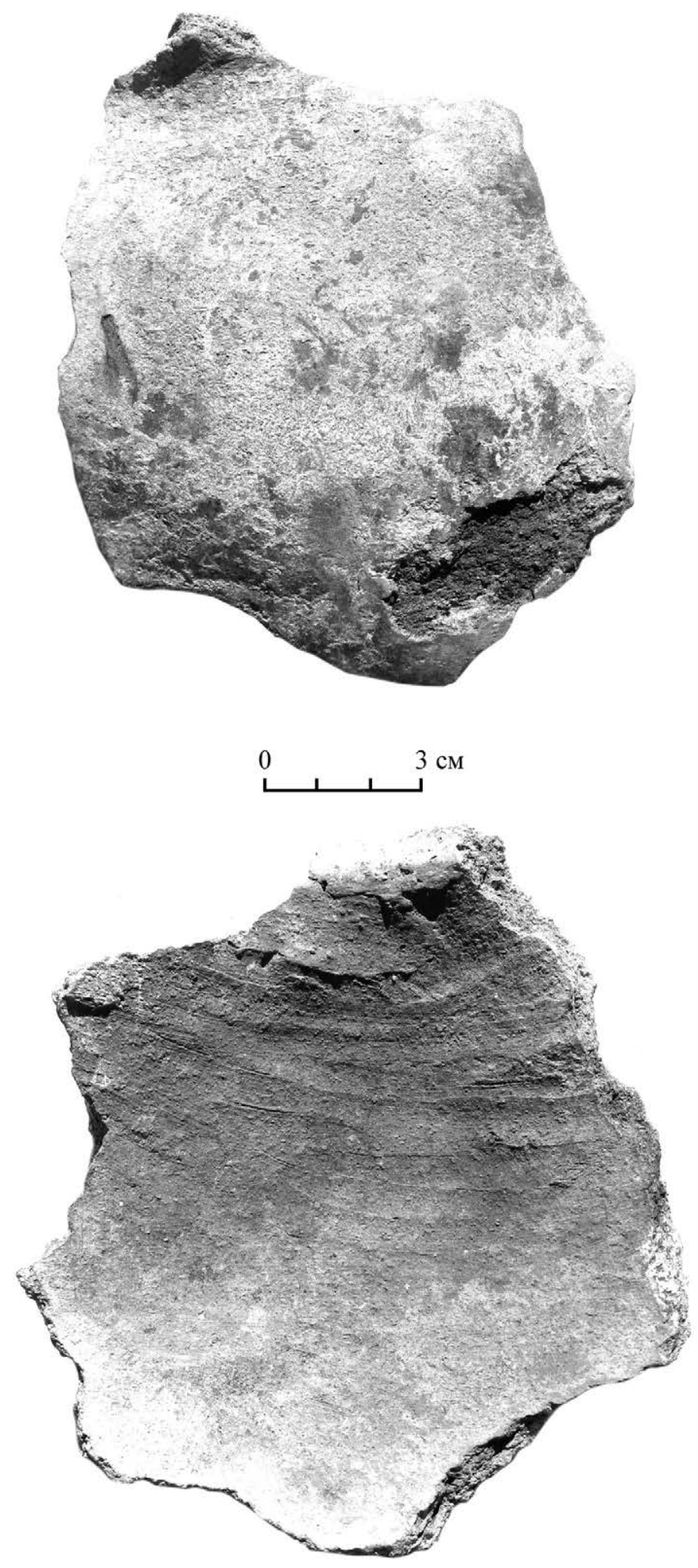

Рис. 88. Раскоп 5. 2015 г. Керамика с минеральными примесями 

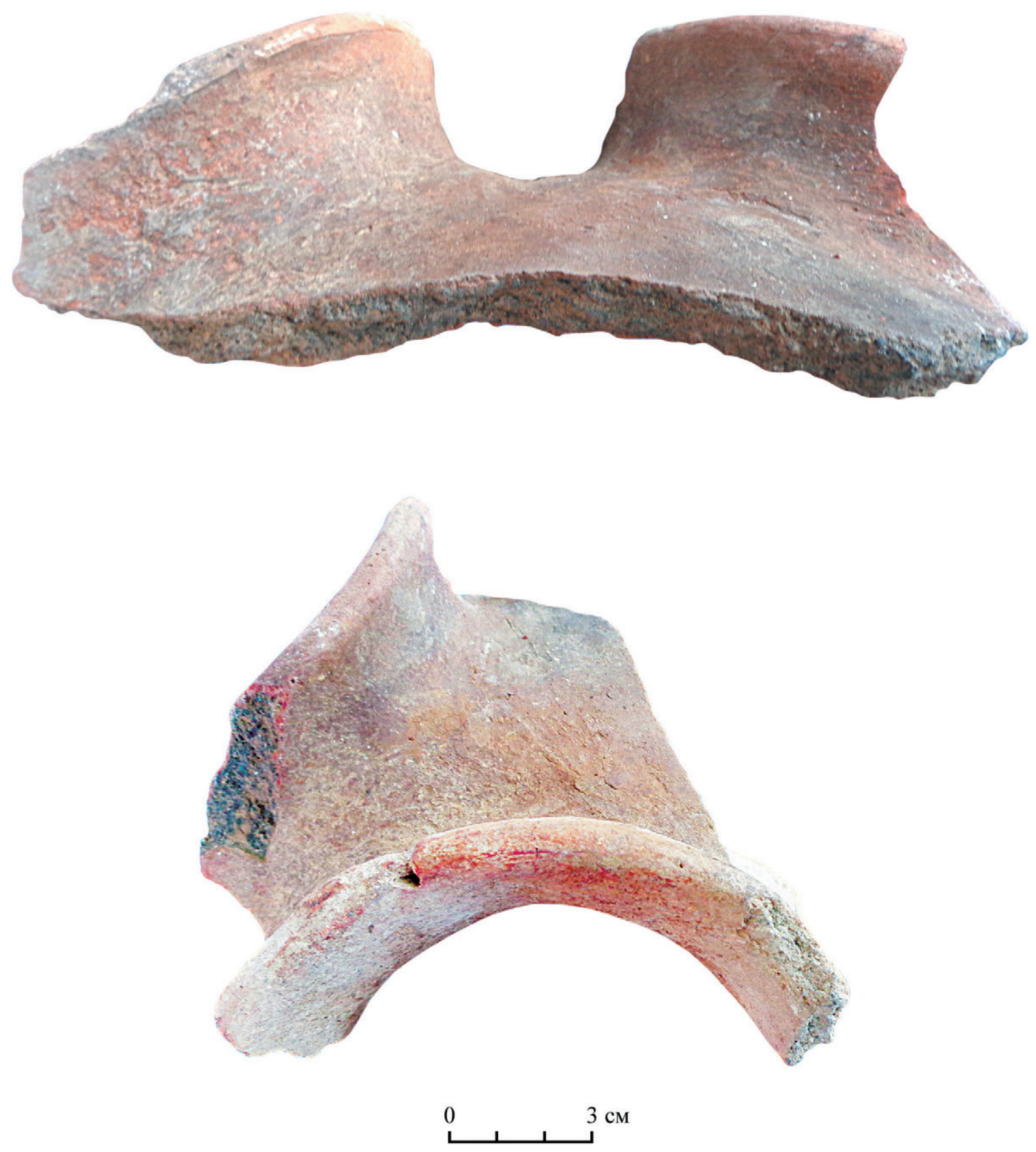

Рис. 89. Раскоп 5. 2015 г. Фрагмент двугорлого сосуда 

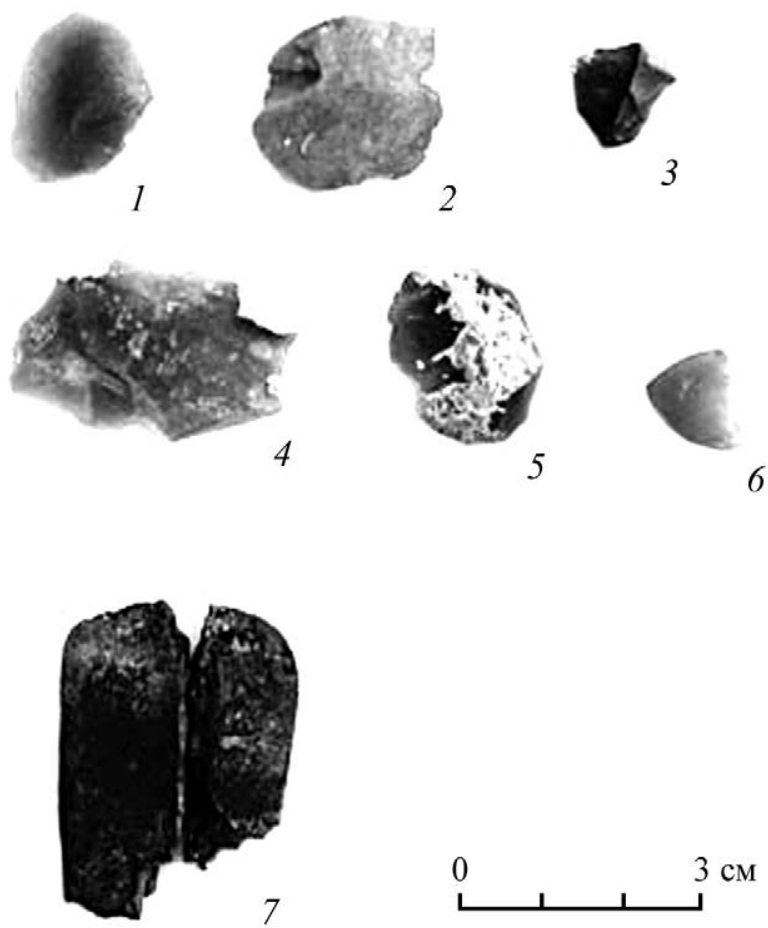

Рис. 90. Раскоп 5. 2015 г. Обугленное костяное лощило, сколы кремня 1-6- сколы кремня, 7-лощило
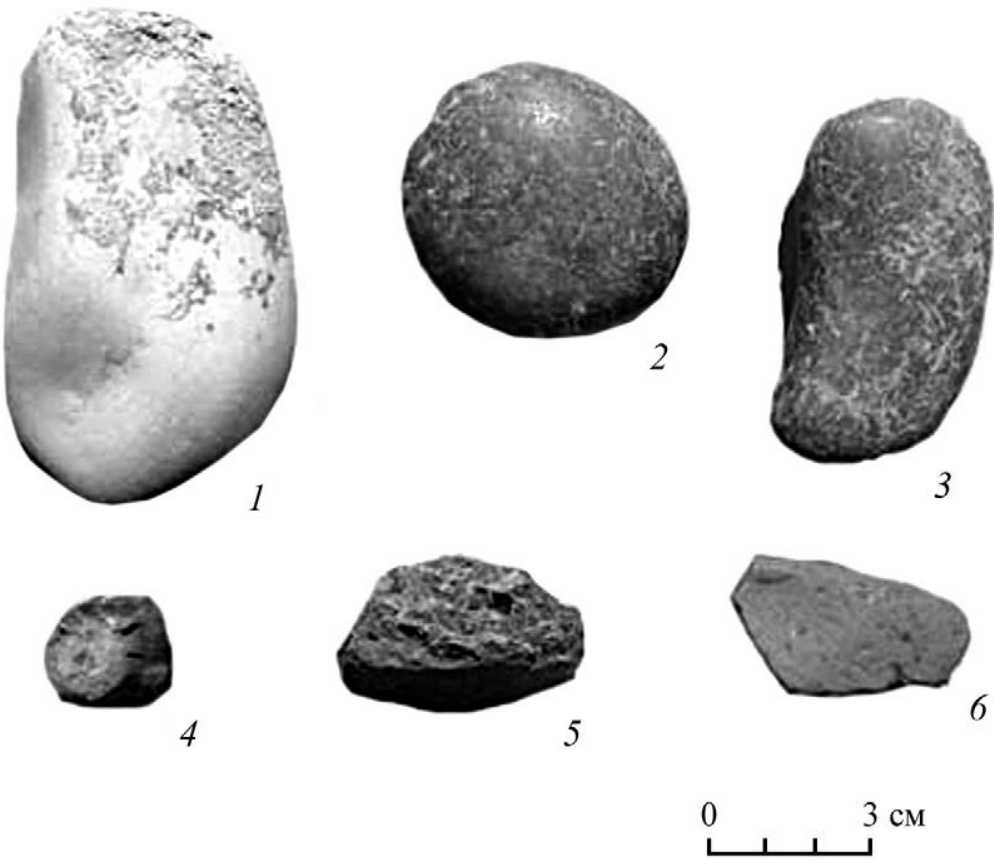

Рис. 91 Раскоп 5. 2015 г. Находки

1-3- гальки, 4, 5- поделки из глины, 6-желтый минерал 


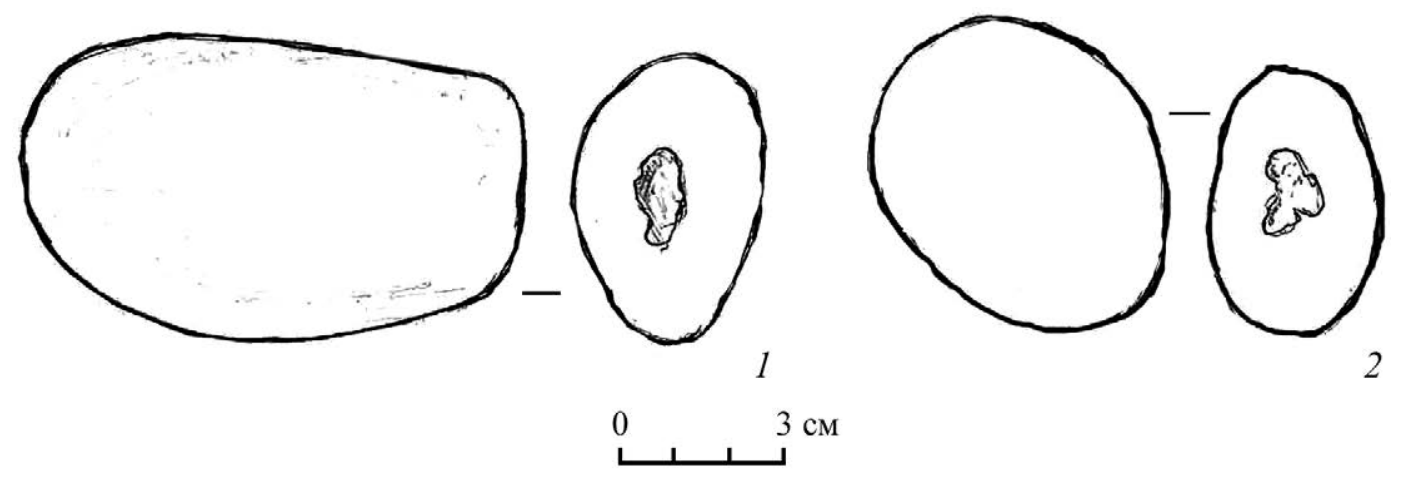

Рис. 92. Раскоп 5. 2015 г. Гальки со следами ударных поверхностей 


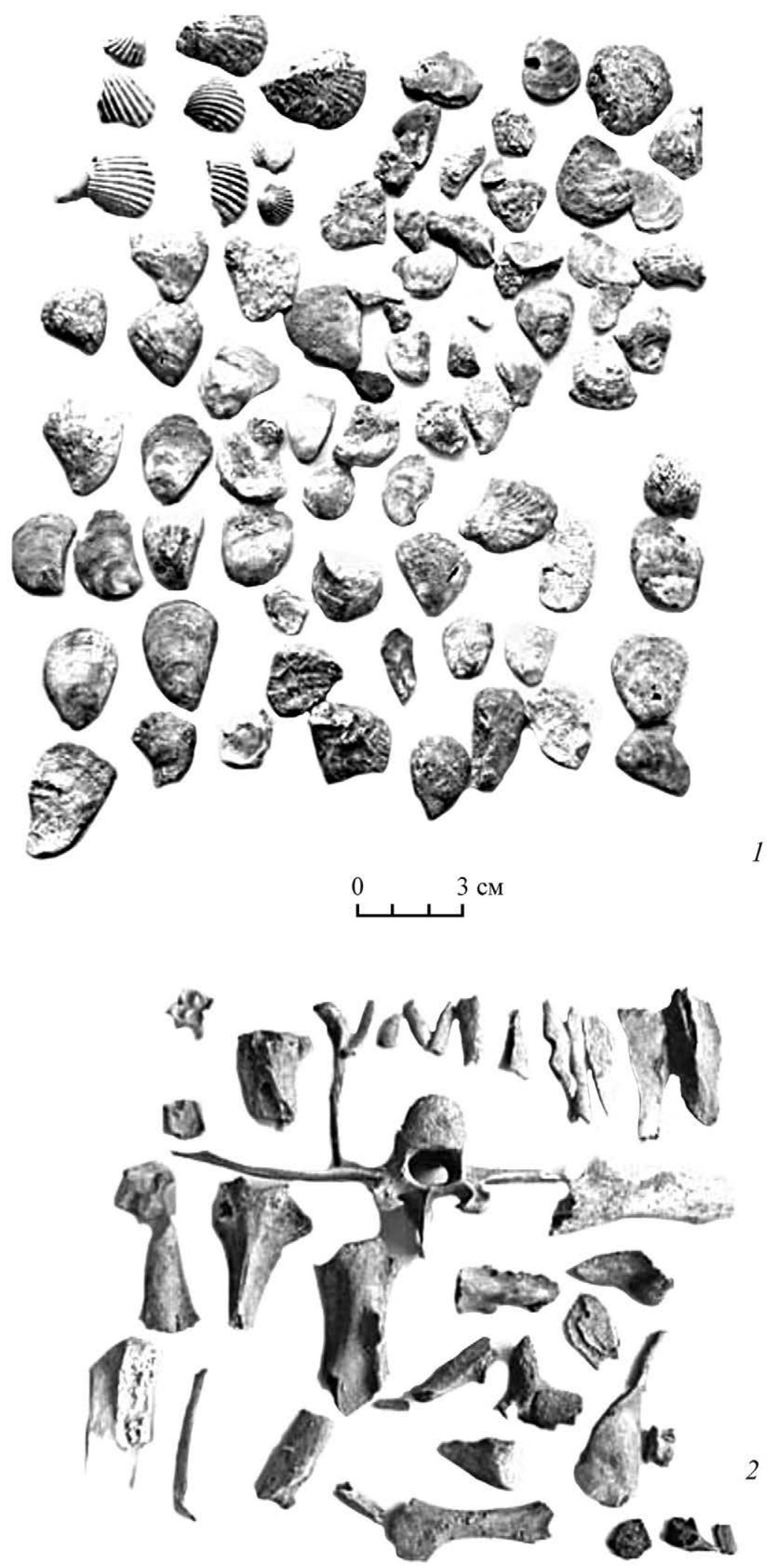

Рис. 93. Раскоп 5. 2015 г.

1 - находки раковин, 2 - кости животных 


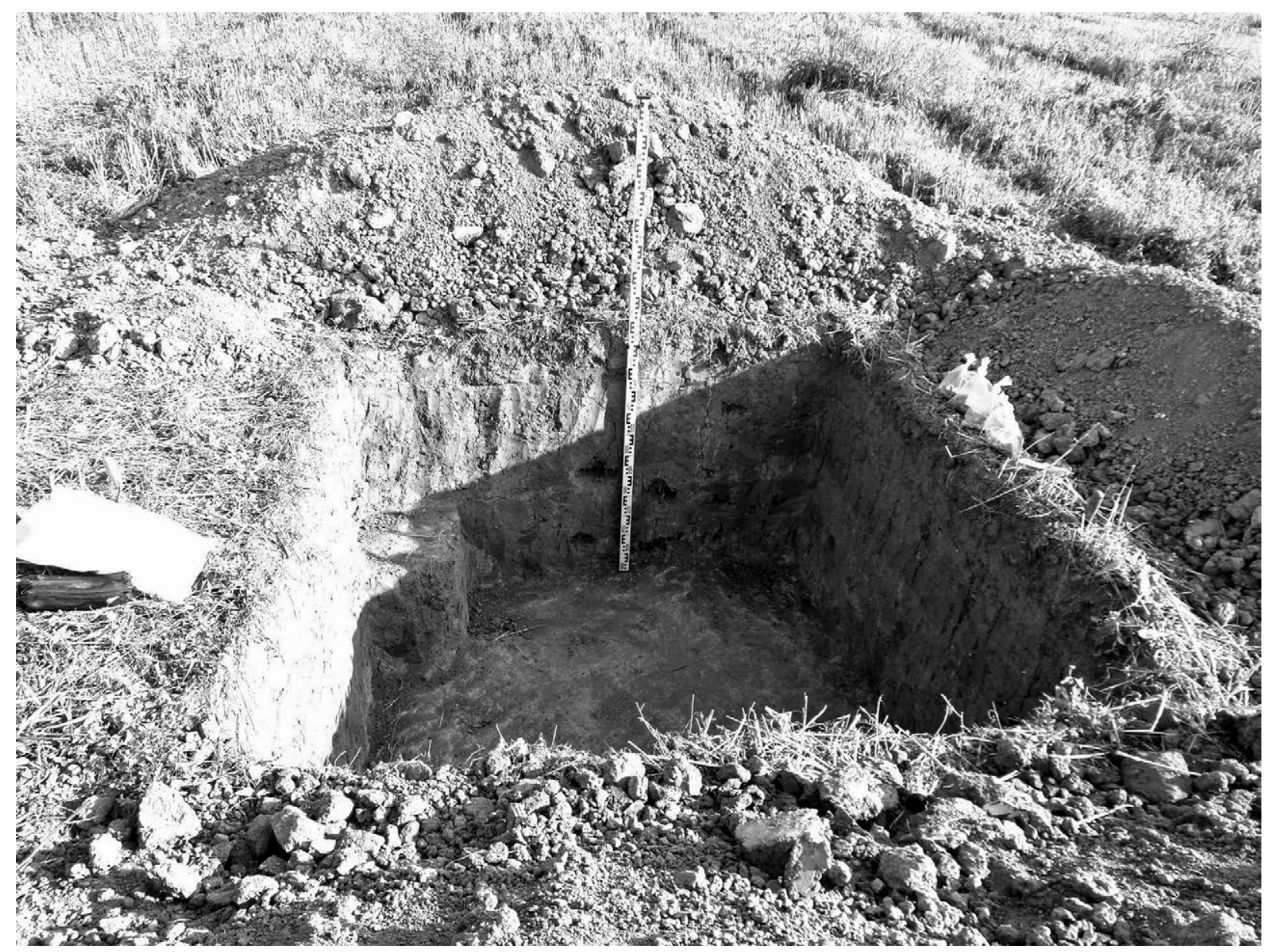

Рис. 94. Раскоп 7. 2015 г. Находки костей животных 

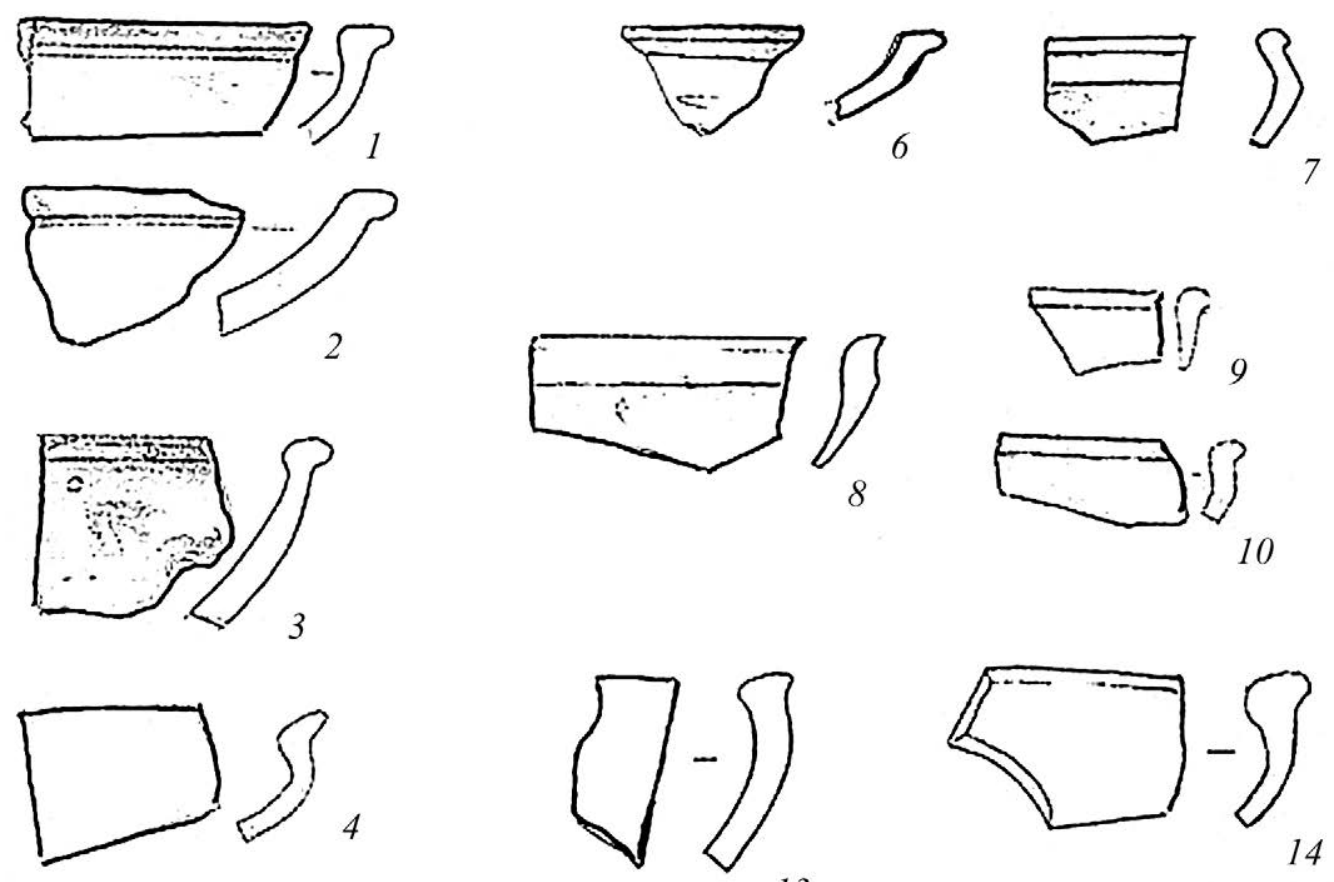

13
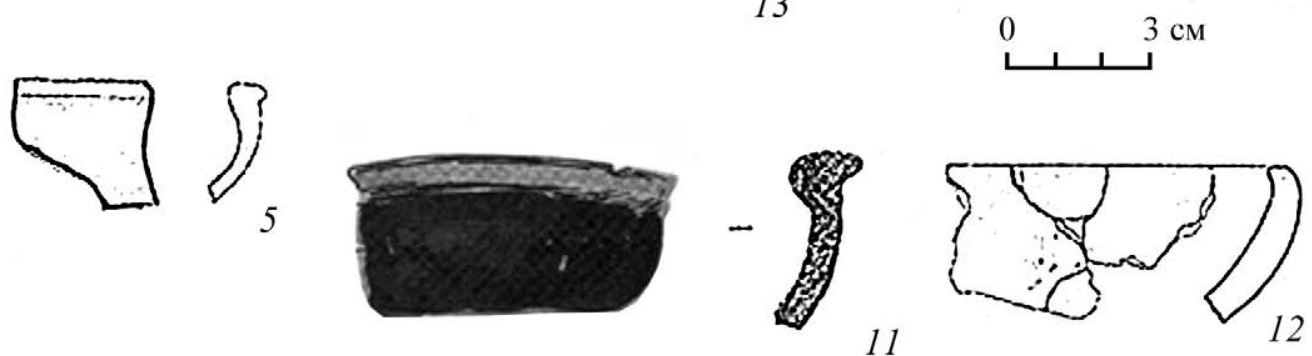

Рис. 95-1. Фрагменты венчиков мисок 1 класса поселения Тузла-15 

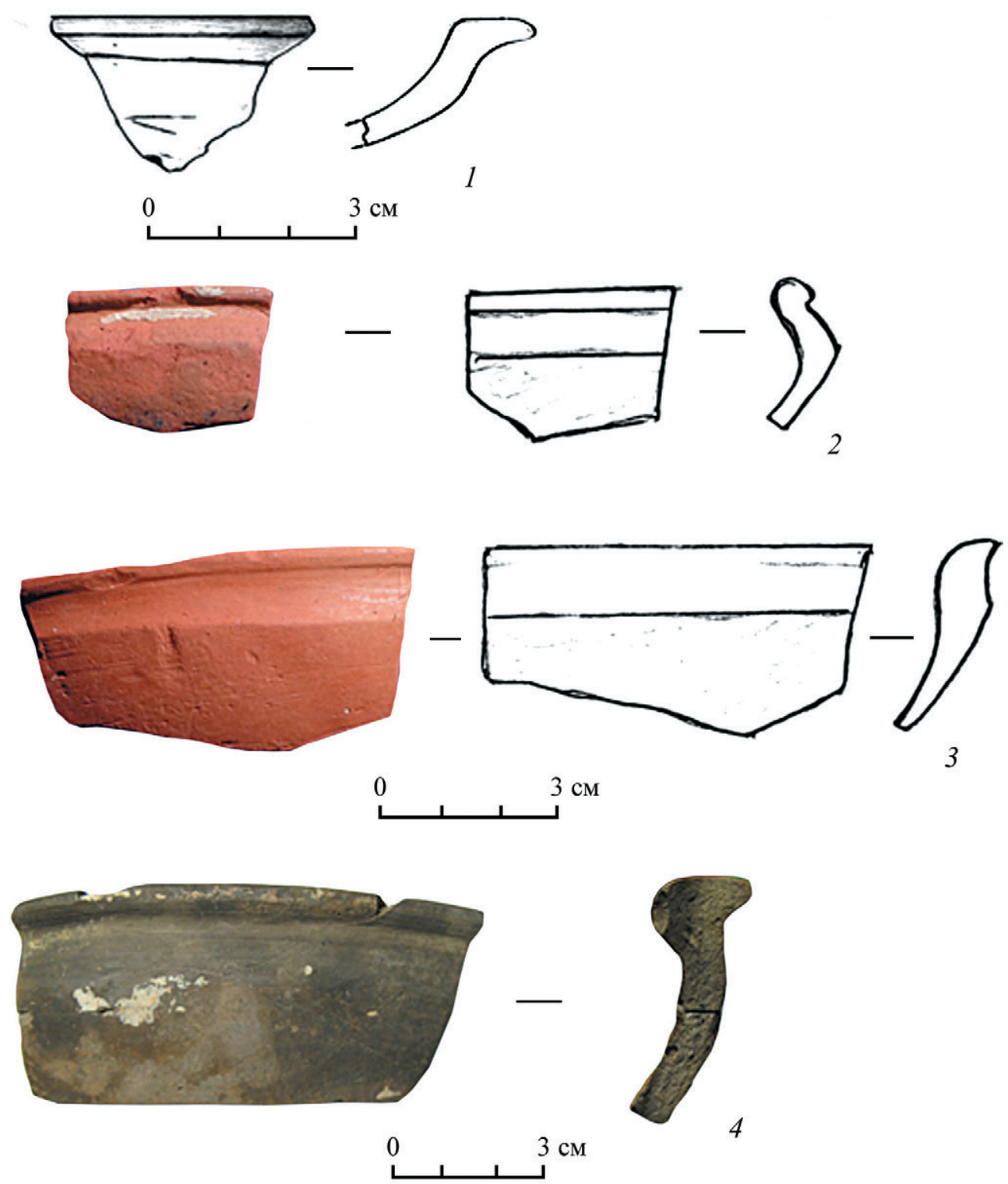

4

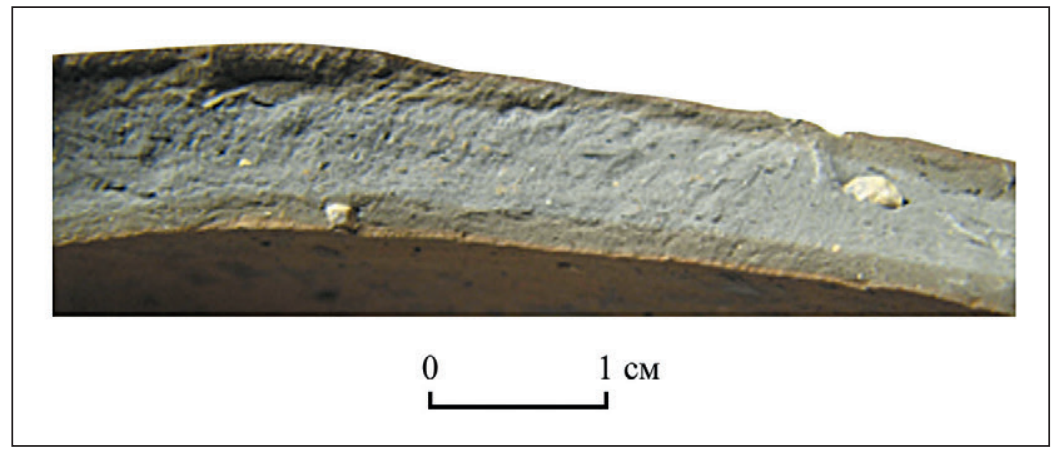

Рис. 95-2. Фрагменты сосудов Тузла-15 

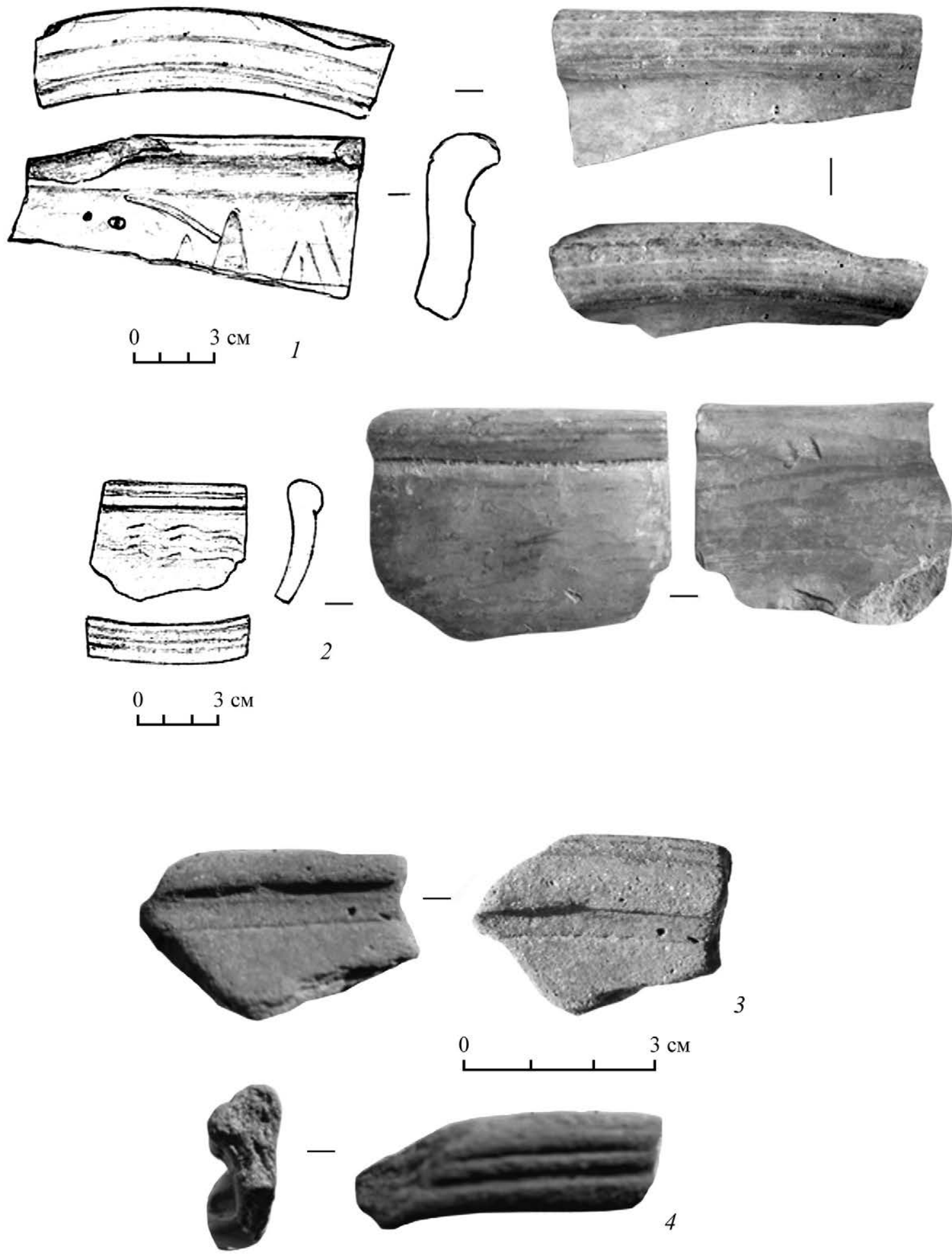

Рис. 96-1. Сосуды 1 класса. Тузла-15 

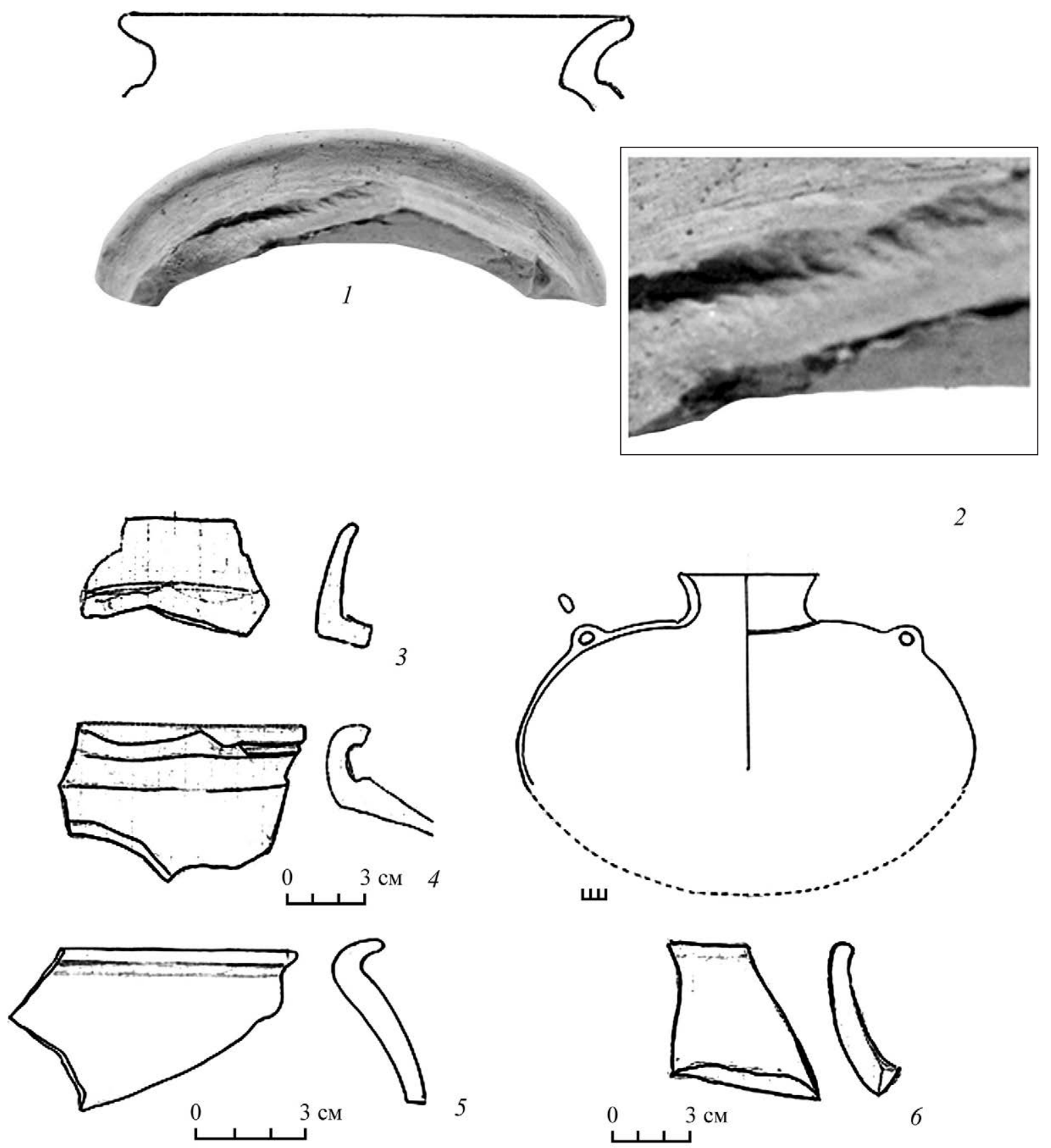

Рис. 96-2. Фрагменты сосудов Тузла-15 со следами вращения 

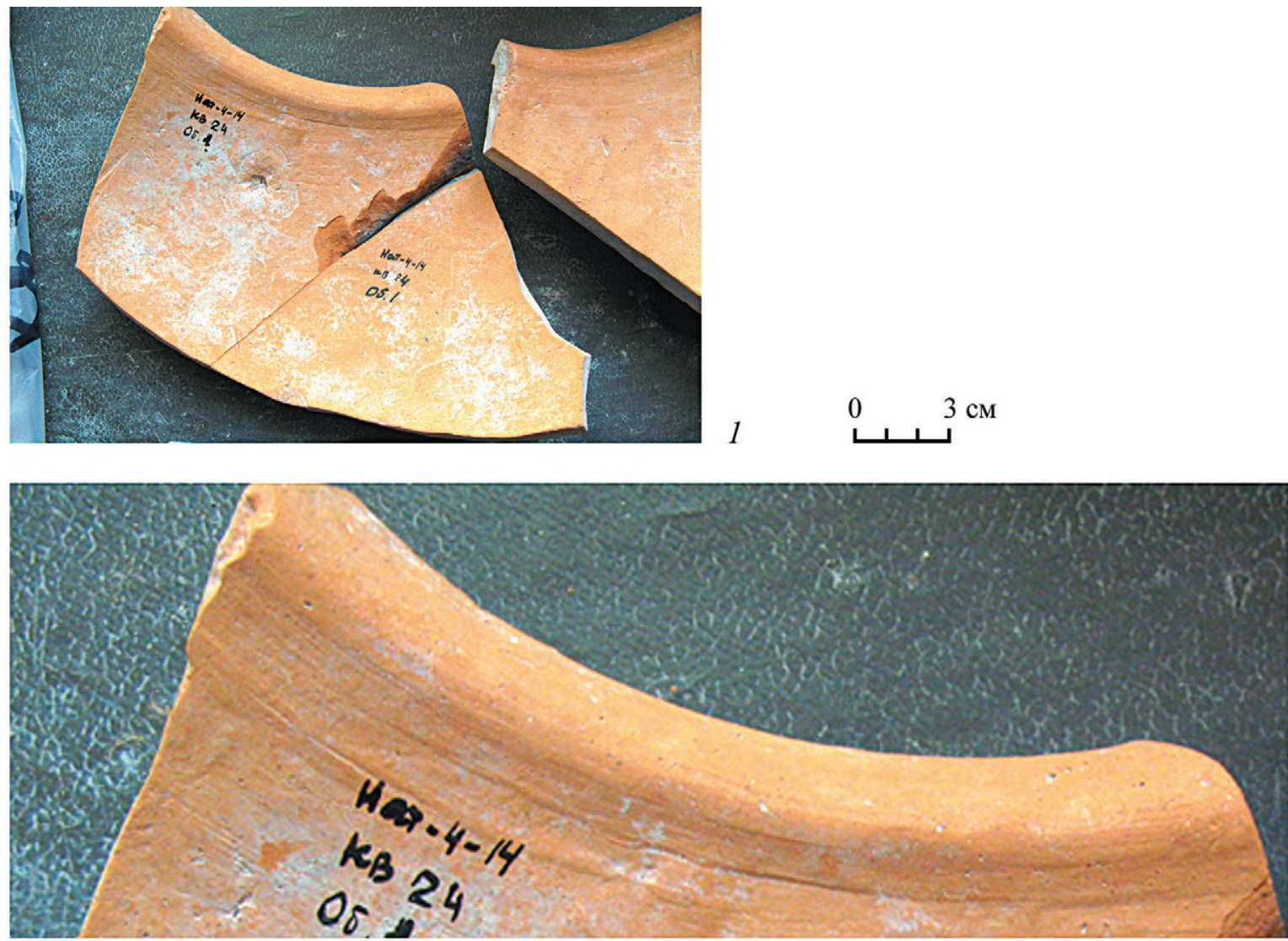

2
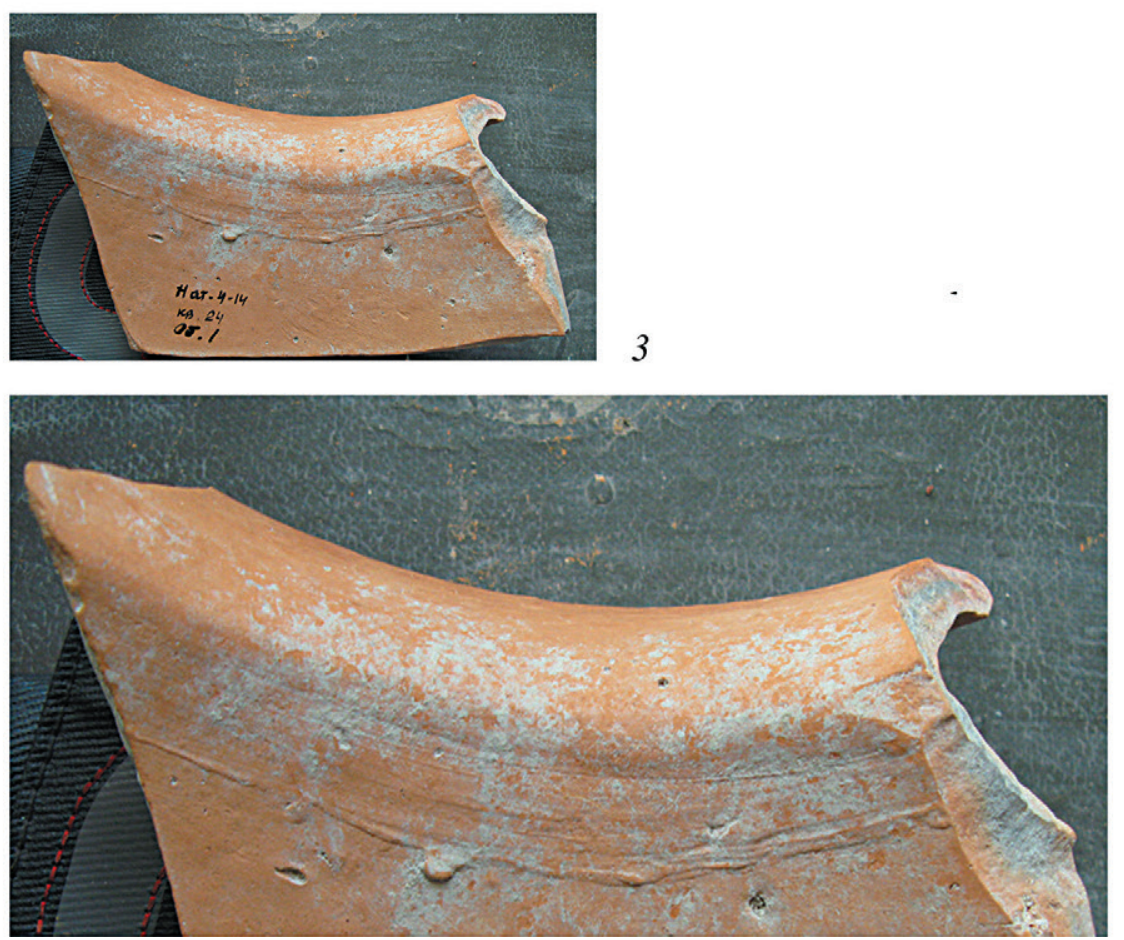

4

Рис. 97. Фрагменты сосудов со следами вращения поселении Натухаевское 4 


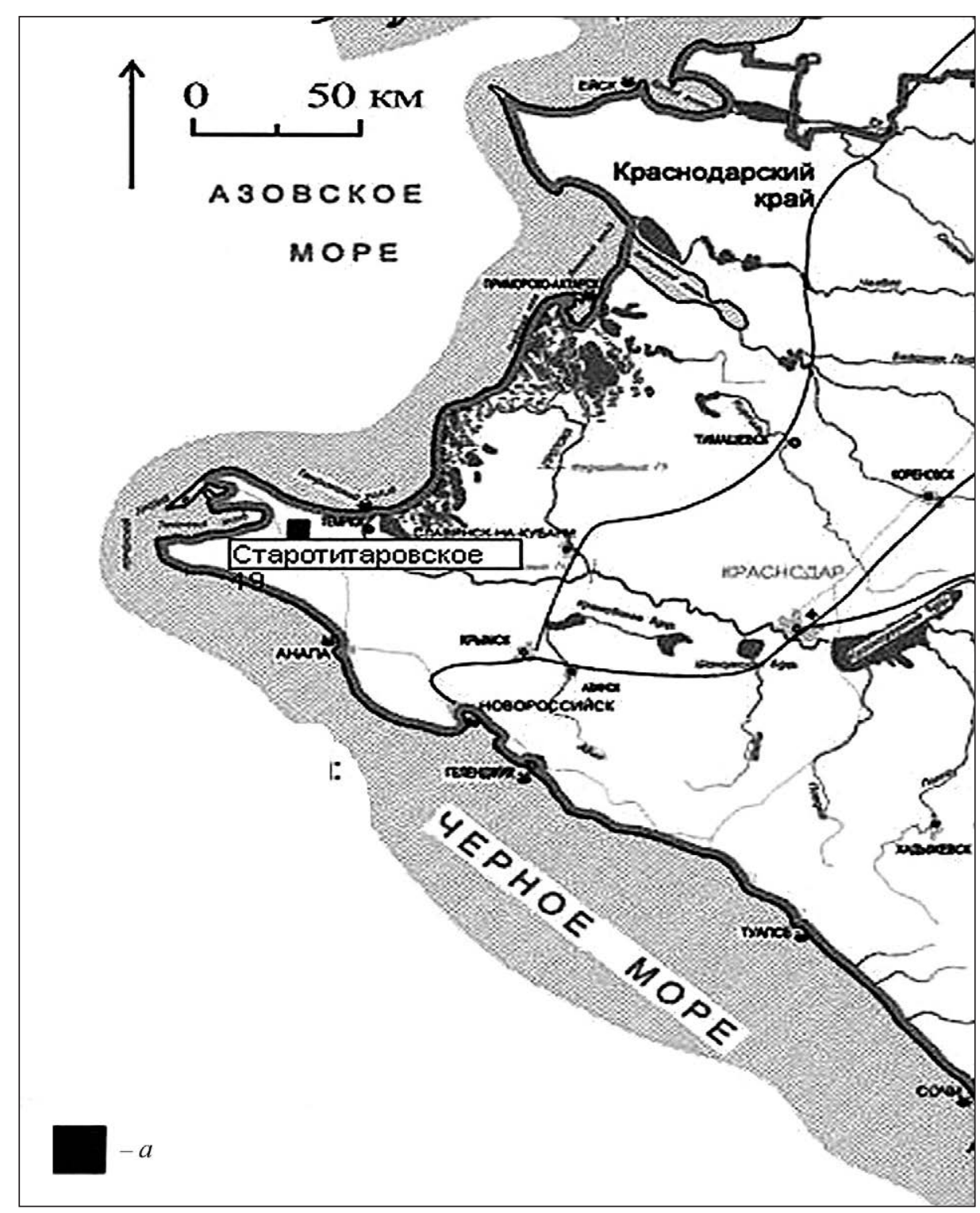

Рис. 98. Место расположения поселения Старотитаровское $a$ - поселение Старотитаровское 

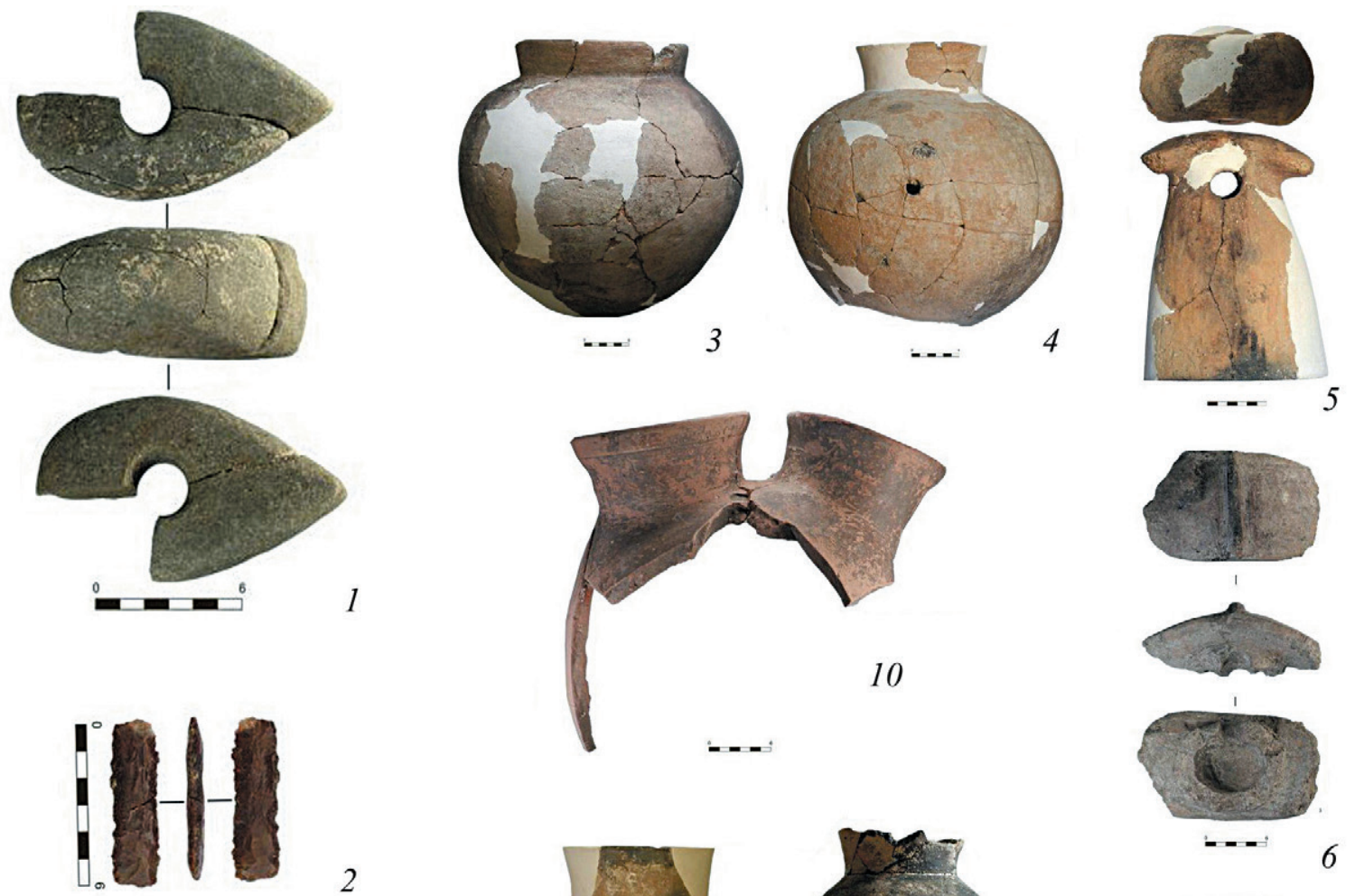

2
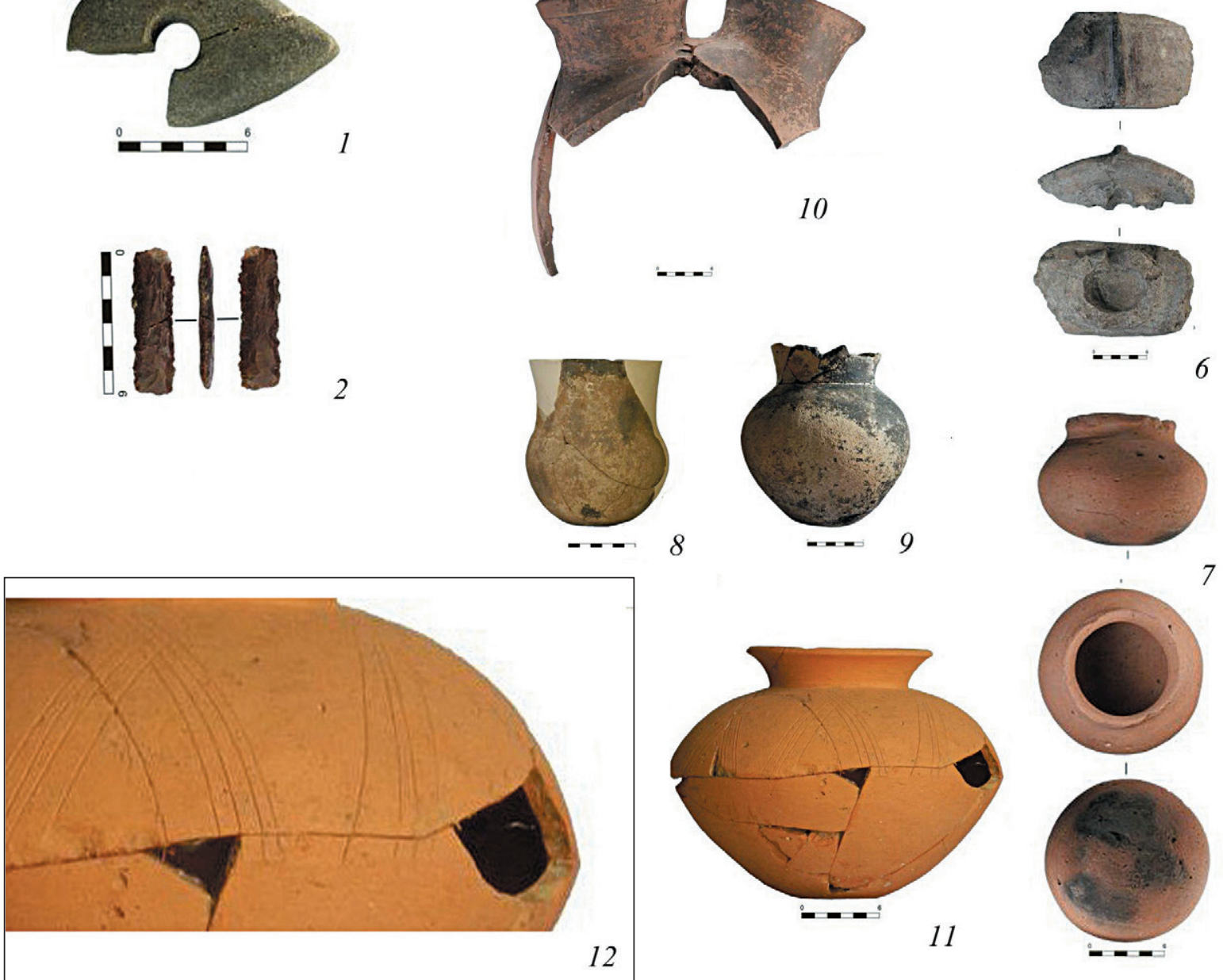

Рис.99. Находки на поселении Старотитаровское

1 - топор-чекан, 2- кремневая пластина, 3-11- керамика 

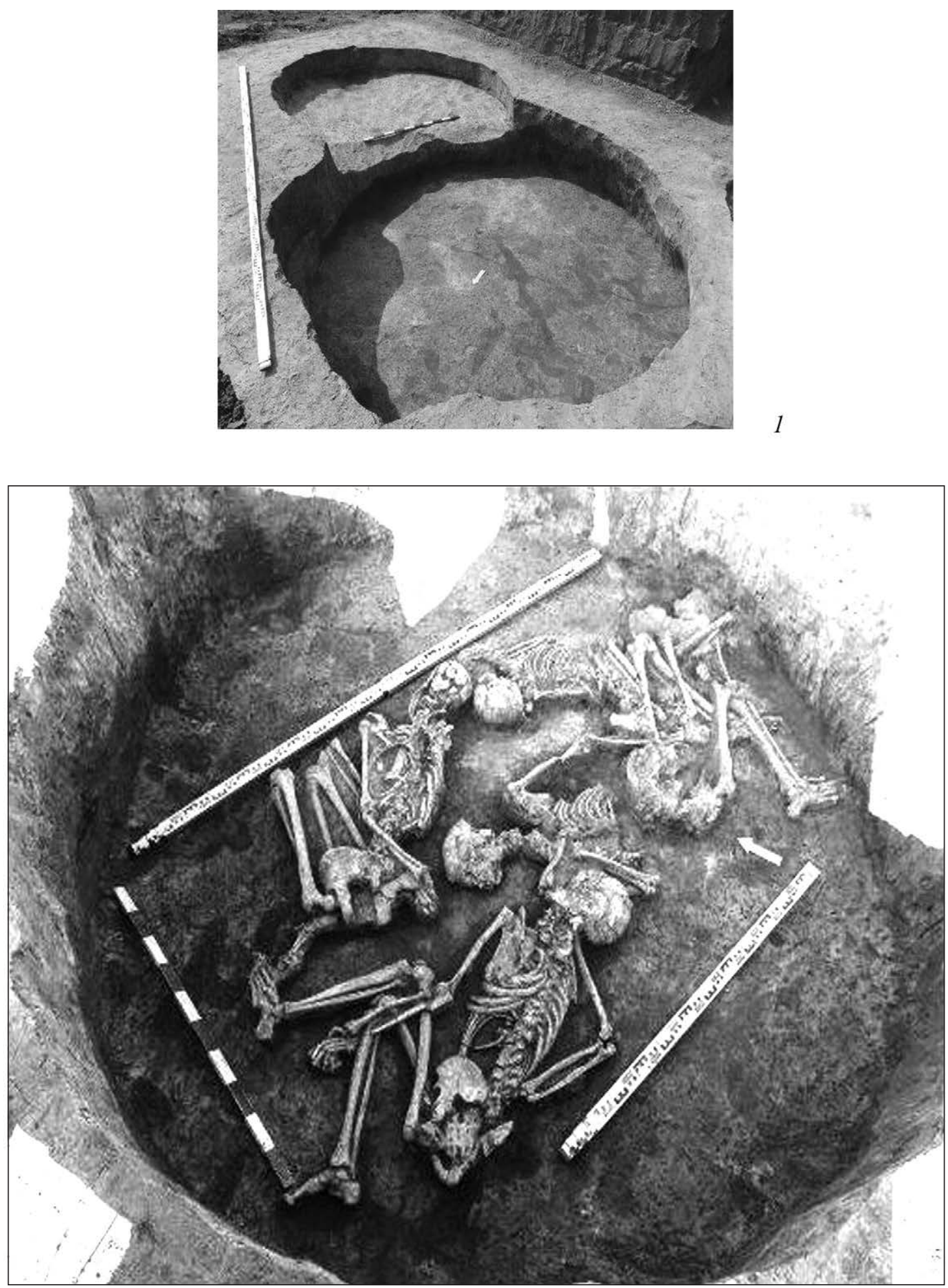

Рис.100-1. План погребения в яме объекта 38-Б

1 - вид на конструкцию ямы, 2 - яма с костяками 


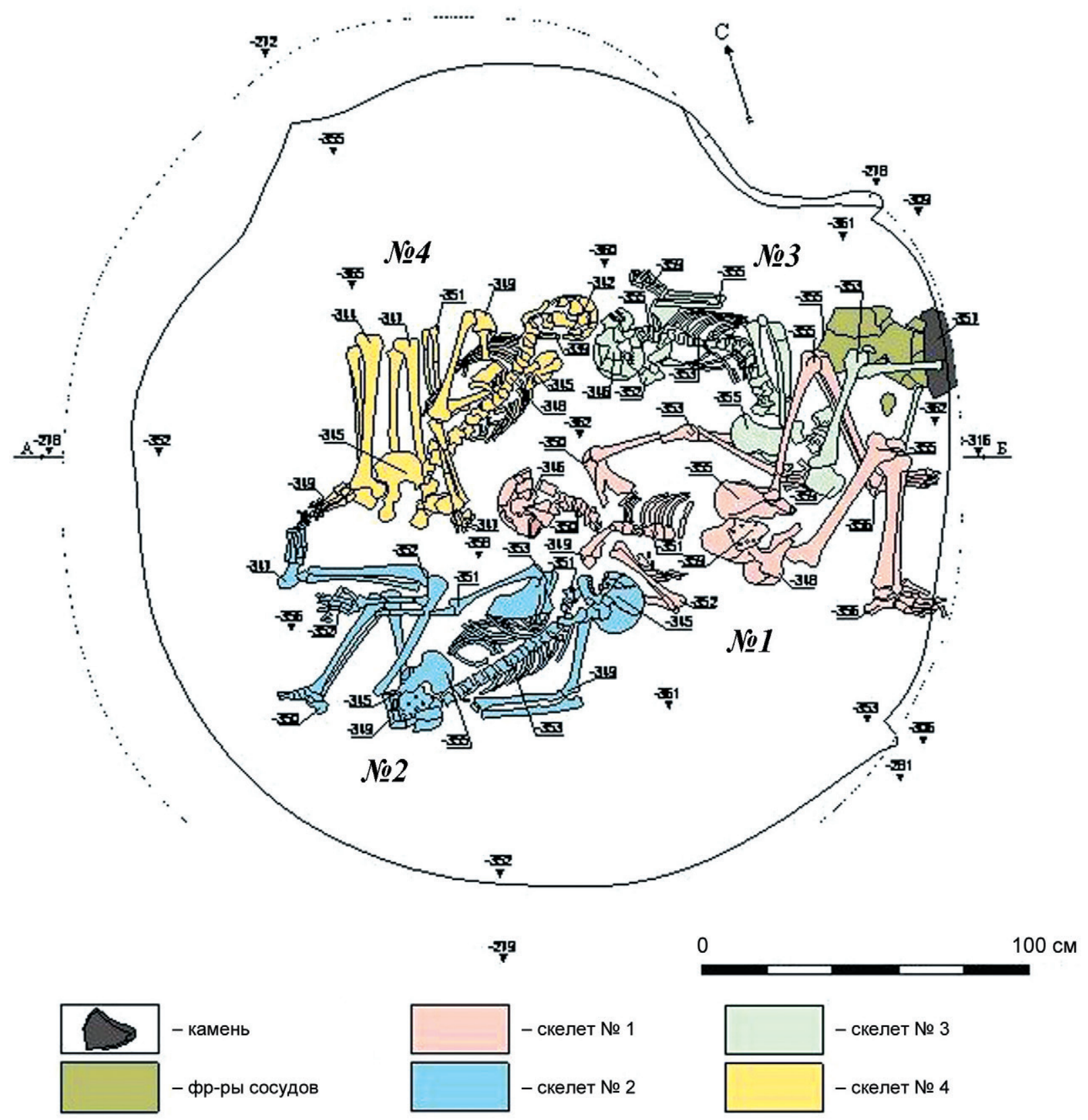

Рис. 100-2. План погребения в яме объекта 38-Б 

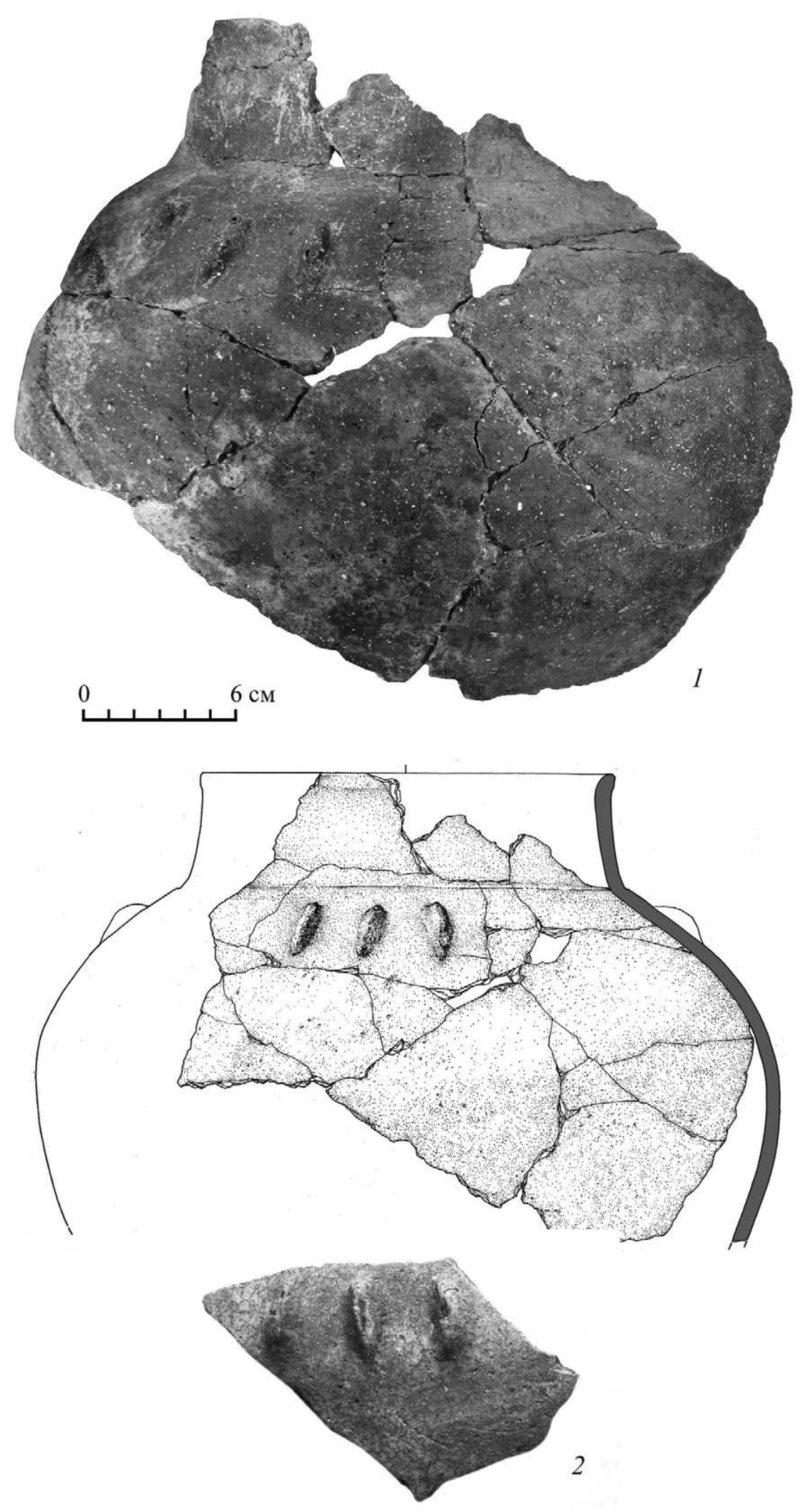

Рис. 101. Находки керамики в яме объекта 38-Б и его аналогия на пос. Тузла-15 1 - пос. Старотитаровское, 2 - пос. Тузла- 15 


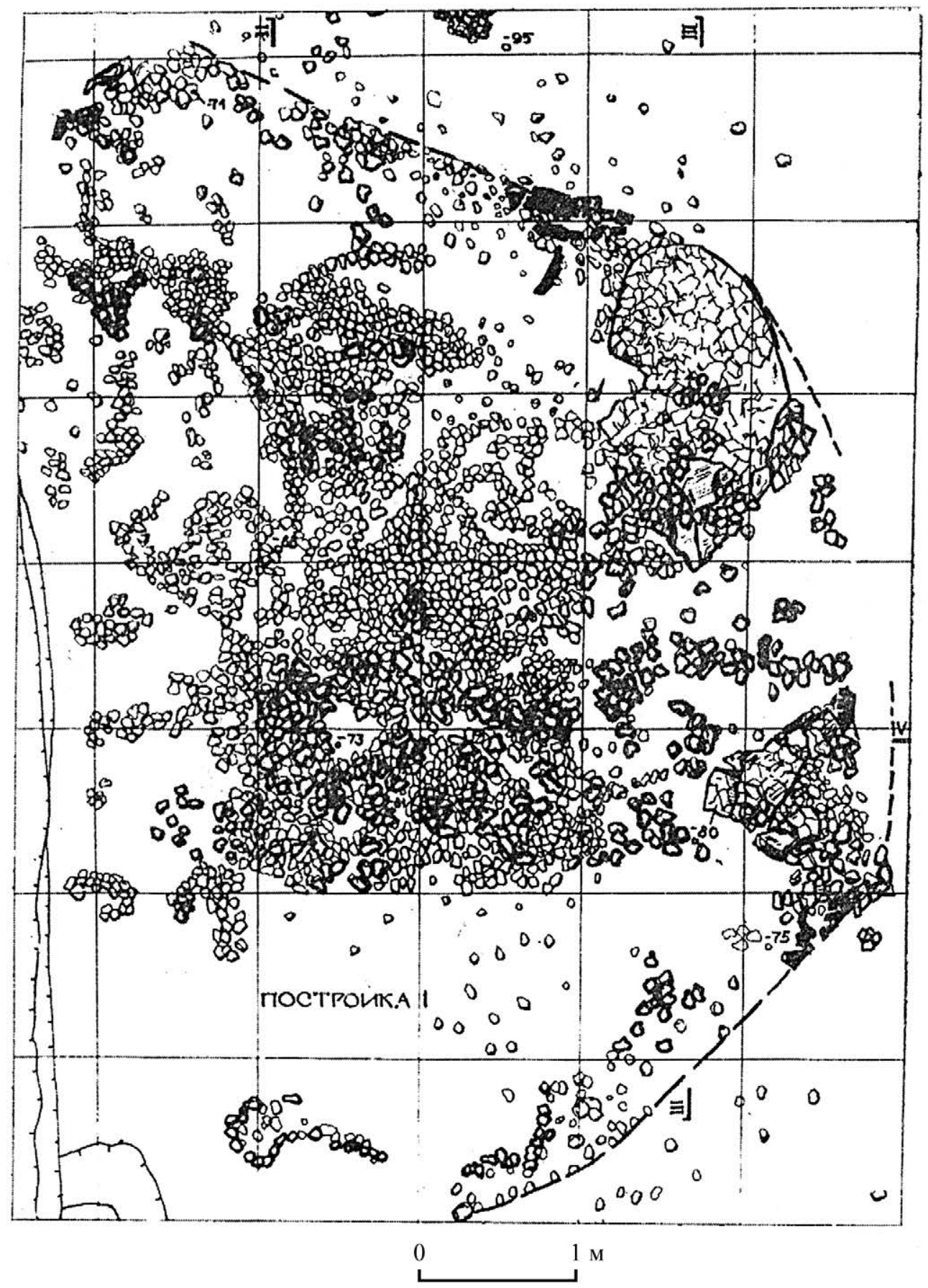

Рис. 102. Постройка 1 с турлучным покрытием Серегинское поселение (по: Днепровский, Яковлев) 


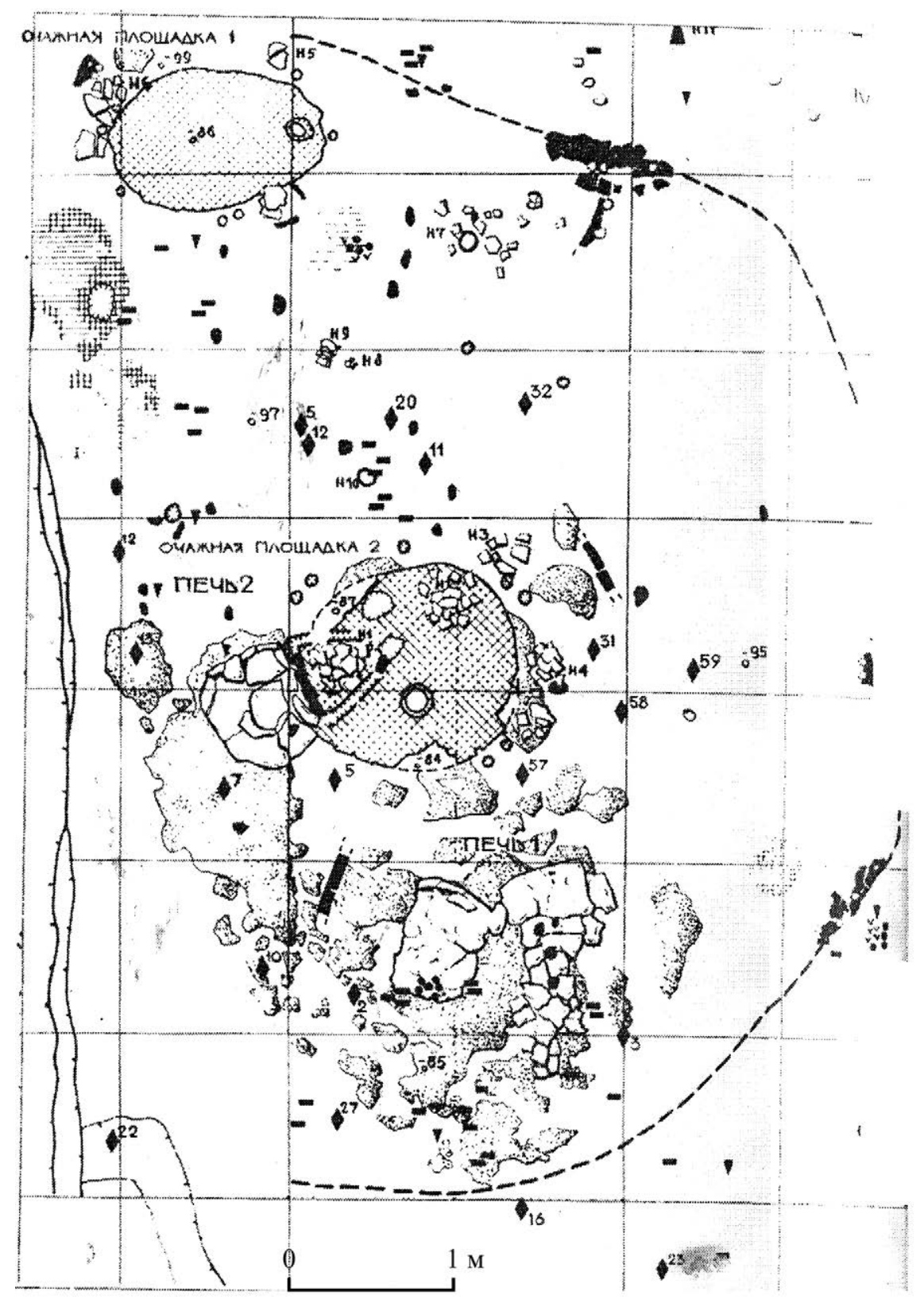

Рис. 103 (99). Постройка I план с очагом Серегинское поселение (по: Днепровский, Яковлев) 


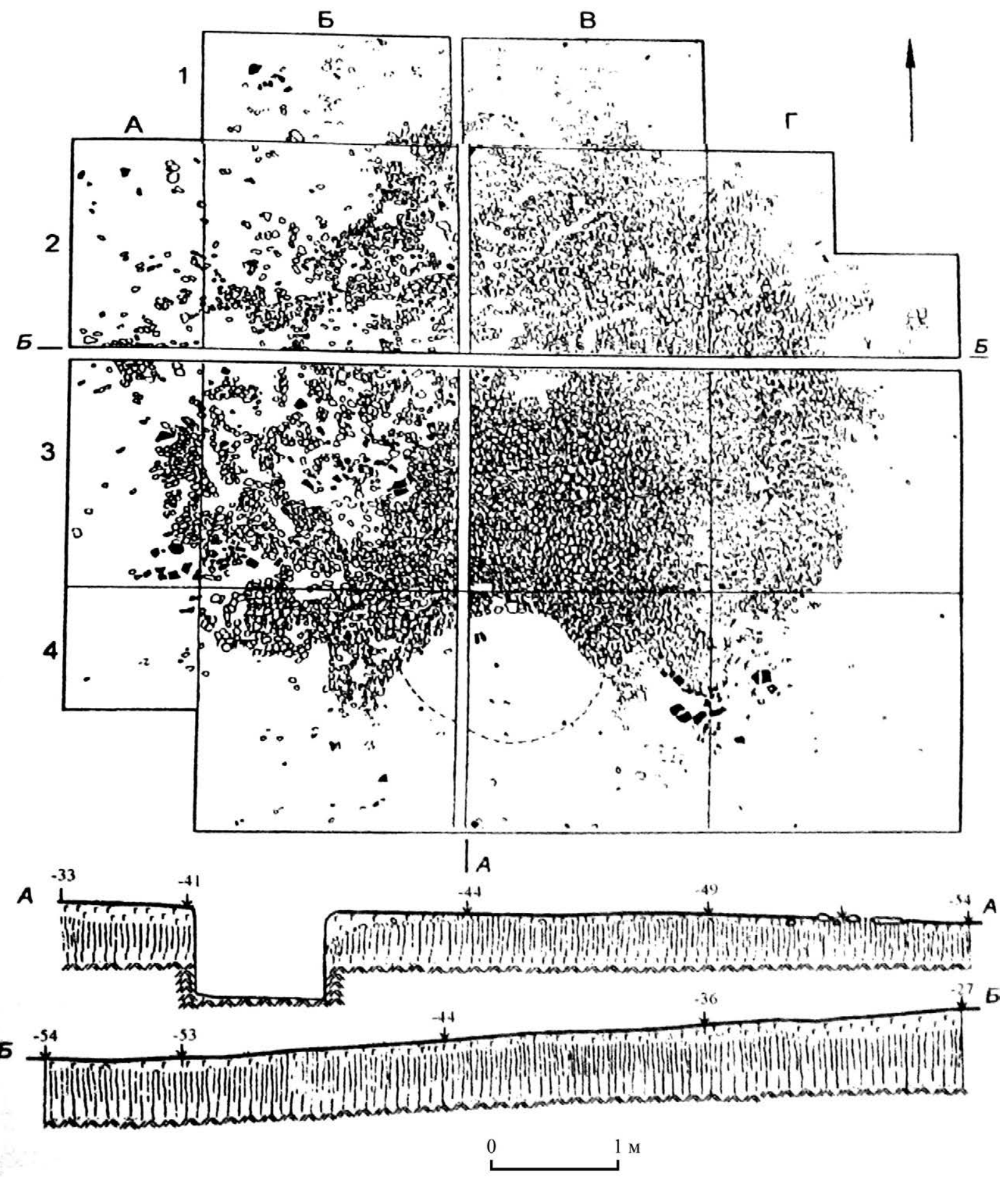

Рис. 104 . Поселение Чишхо жилище 4 (по: Резепкин, Лионне) 


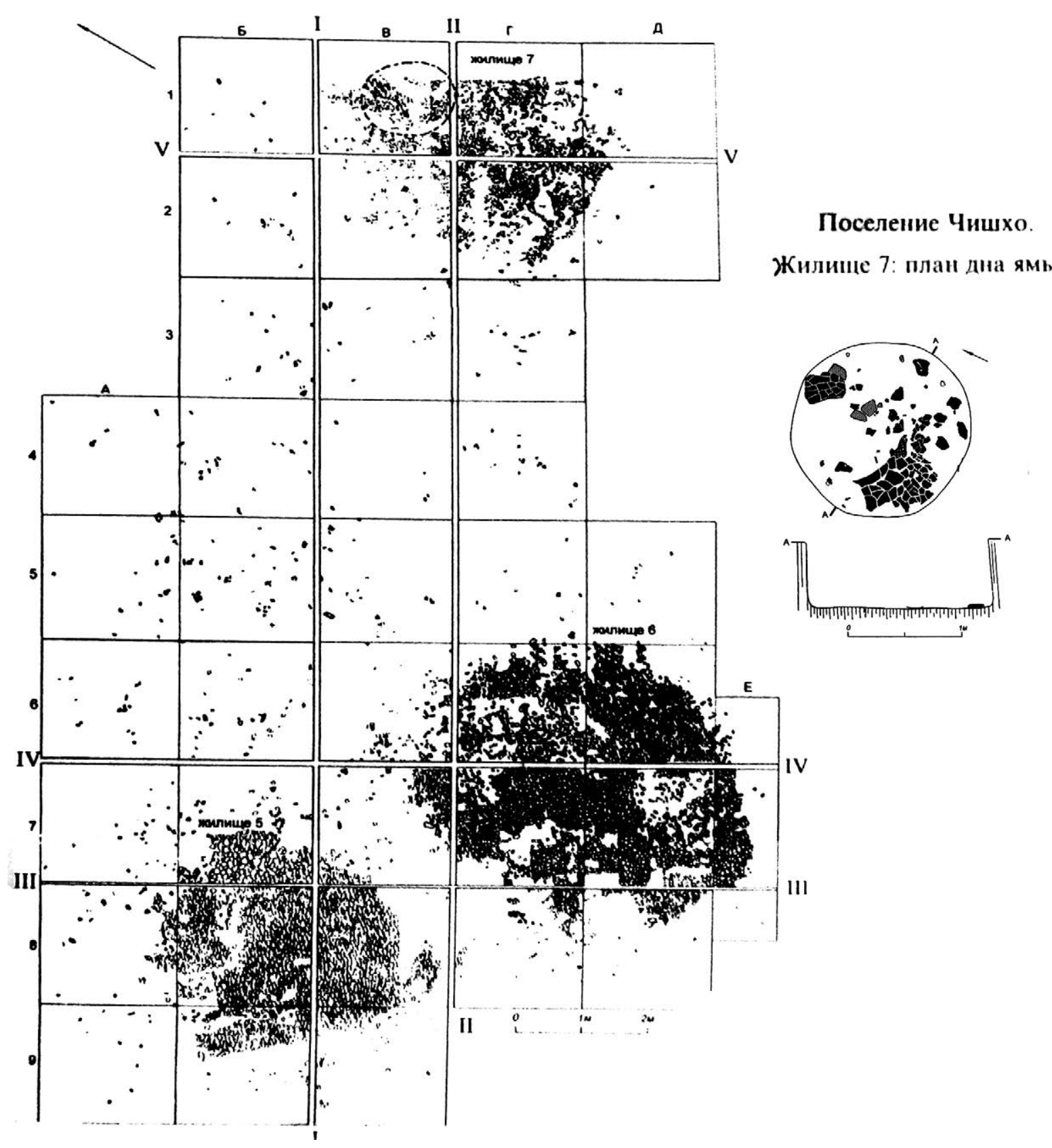

Рис. 105. Посеение Чишхо, жилище 5, 6, 7 (по: Резепкин, Лионне) 

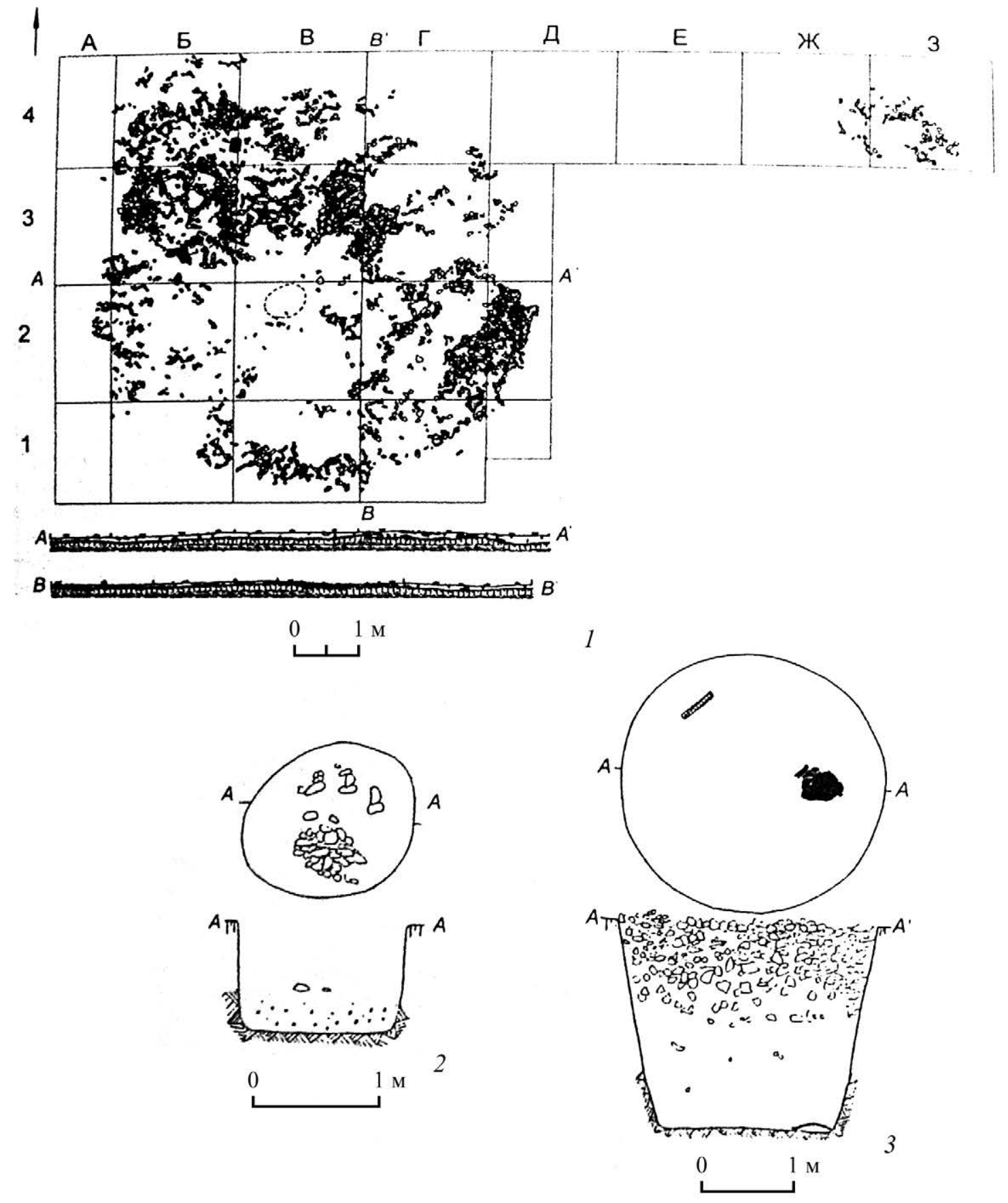

Рис.106. Поселение Городской 1 (по: Резепкин, Лионне) 1 - жилище, 2- очаг, 3-яма 

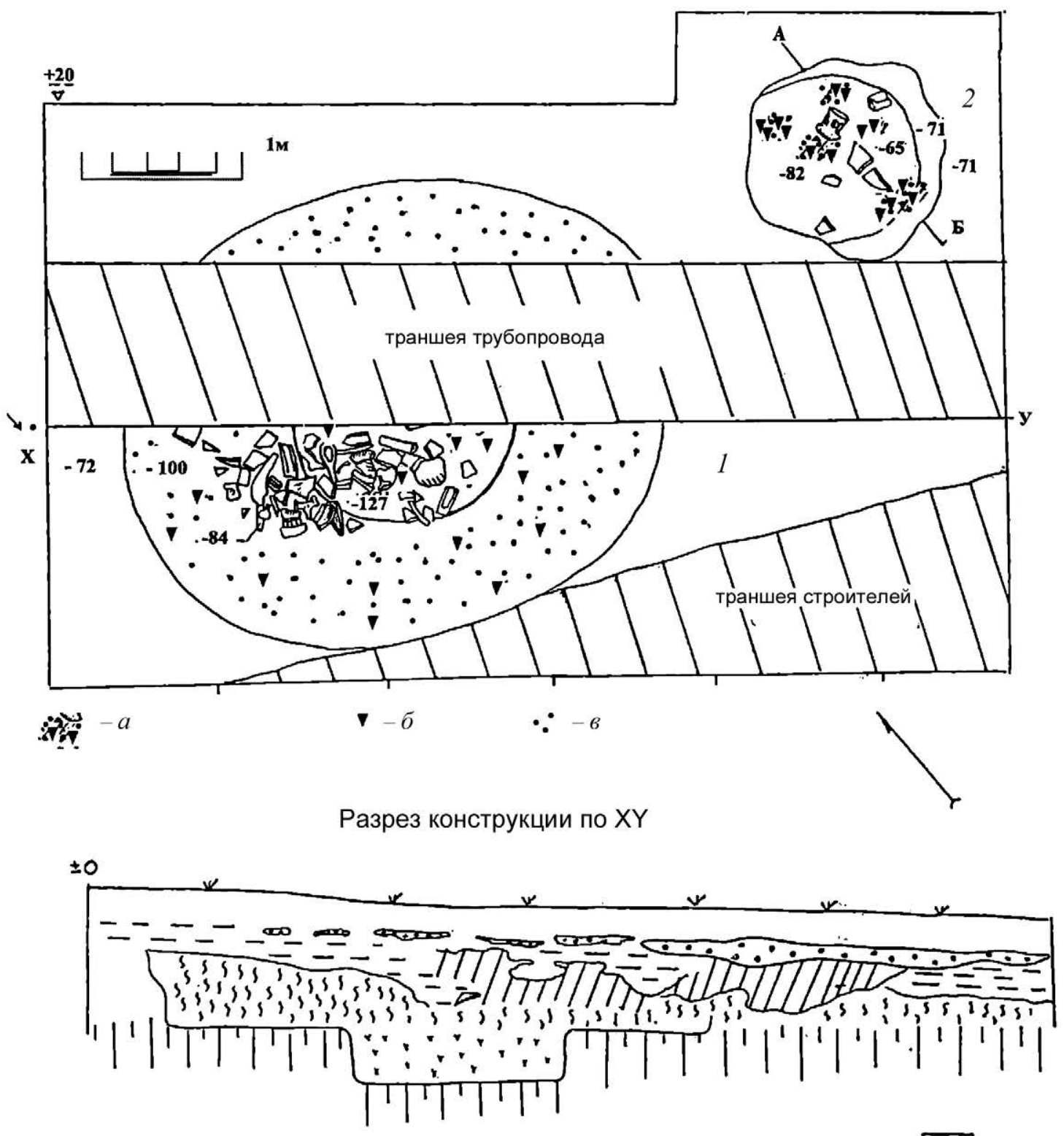

Разрез по АБ малой ямы<smiles>CC(C)CC(C)C(C)C(C)C(C)(C)C(C)(C)C(C)C(C)C(C)C(C)C</smiles>

Рис. 107. Поселение Аликоновское

1 - яма, заполненная костями животных, 2 - очаг

$a$ - зола и прокал почвы, $\sigma$ - уголь, $в$ - горелая красная крошка 


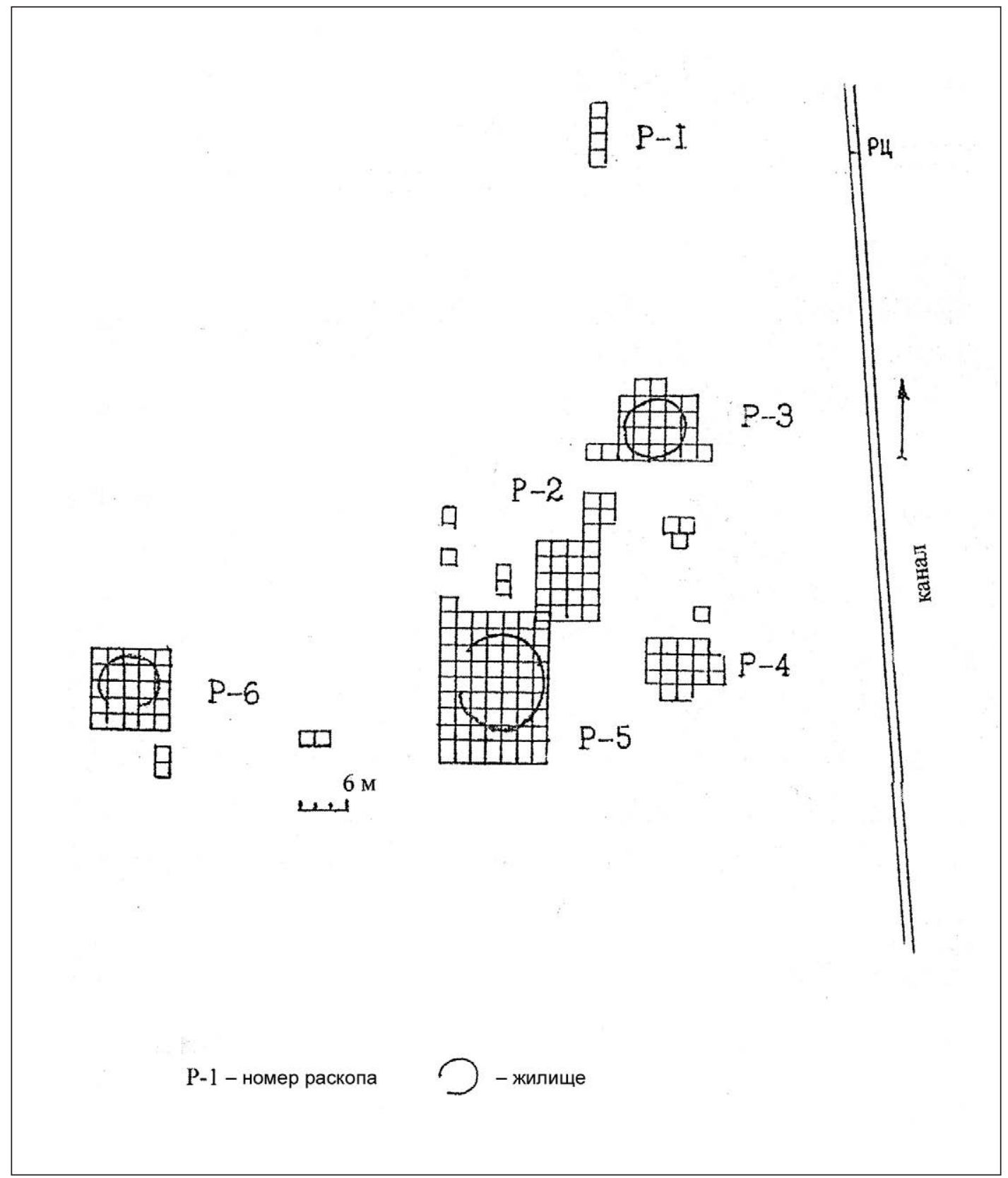

Рис. 108. План раскопок поселения Галюгаевское 1 


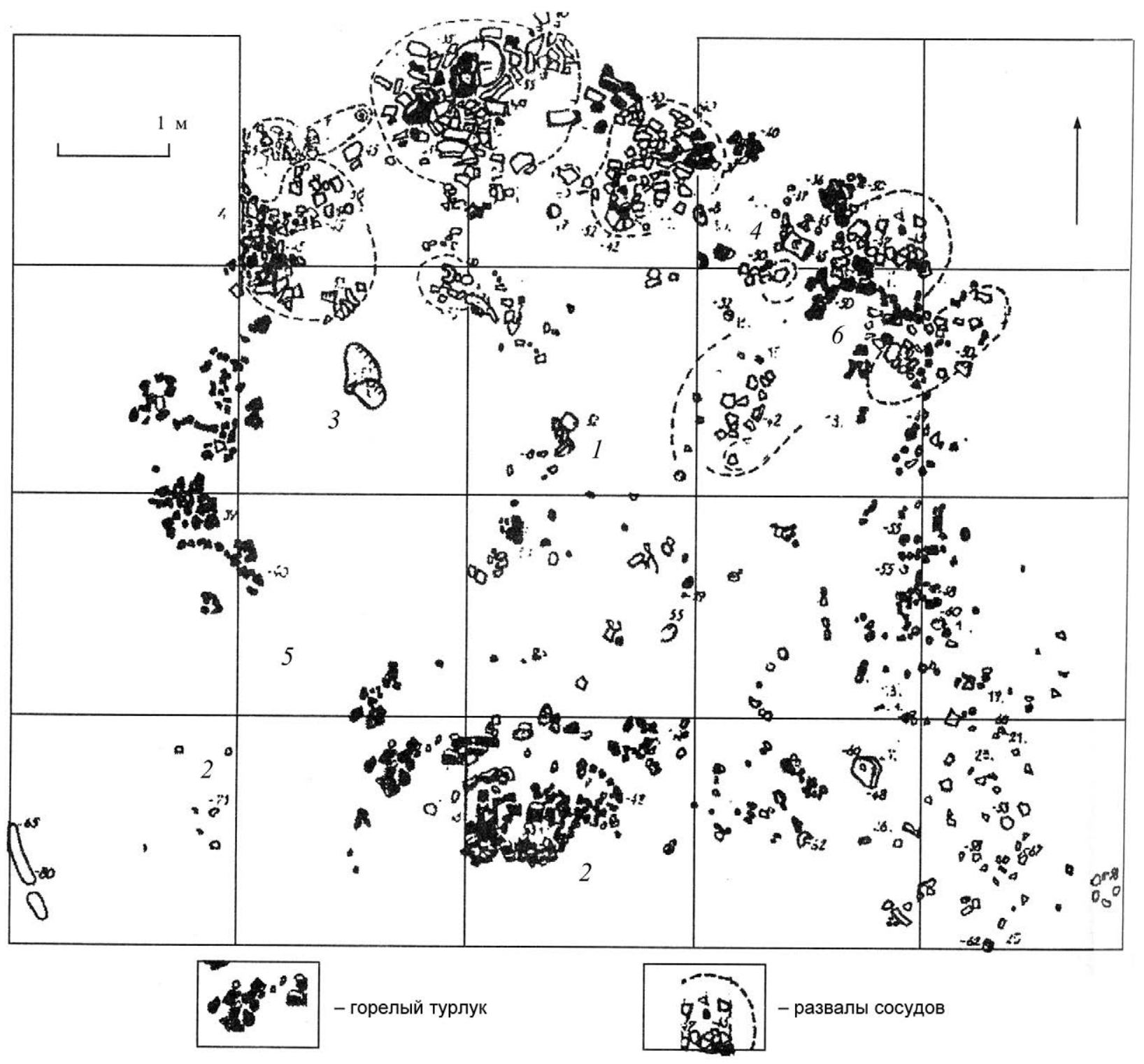

Рис.109. Постройка 1 пос. Галюгаевское 1

1 - место опорного столба, 2- обмазка, горелый турлук, 3- зернотерки, 4- глиняный конус, 5 - предполагаемый вход, 6- место очага 

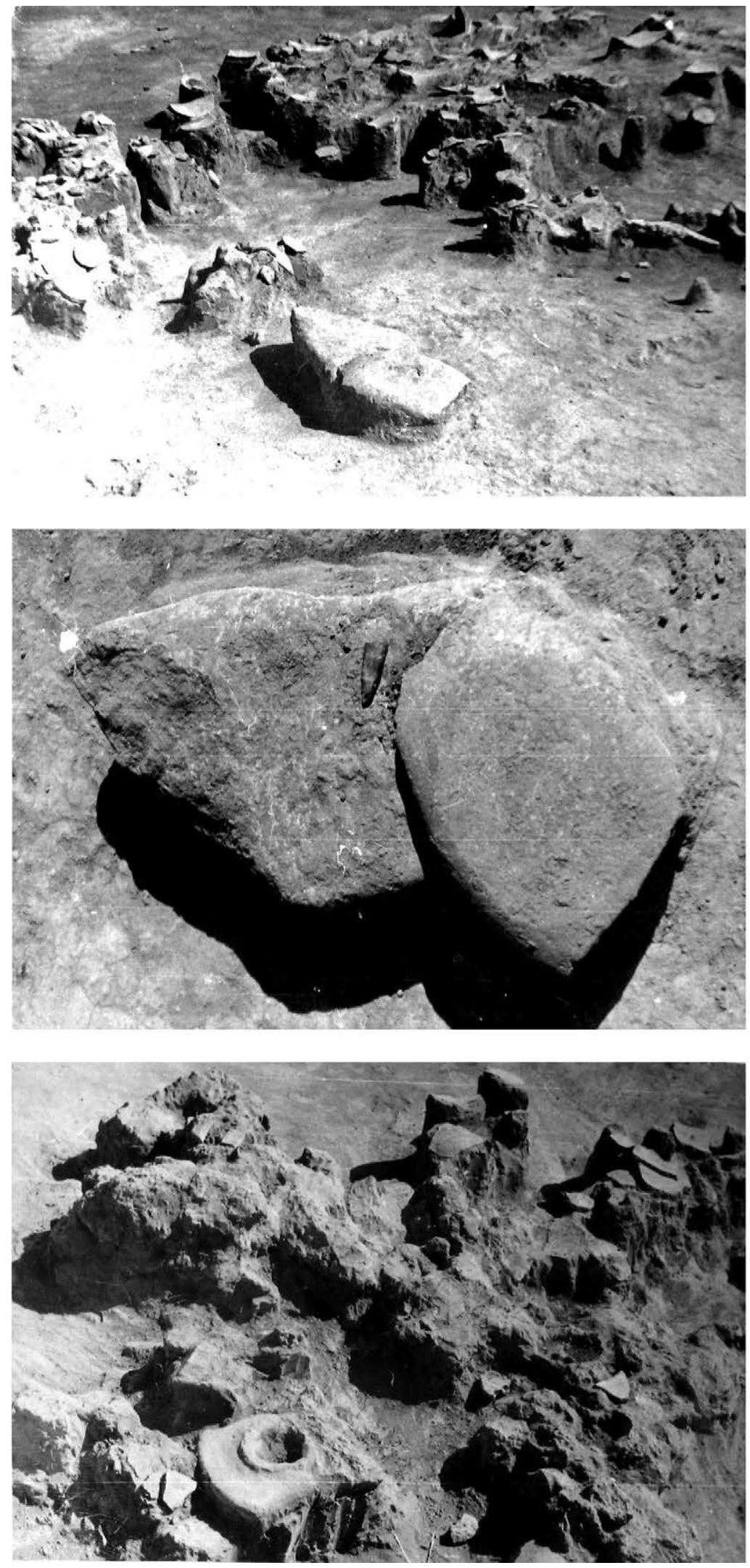

Рис. 110. Постройка 1 пос. Галюгаевское 1

1 - зернотерки (общий вид), 2 - зернотерки, крупный план, 3 -приставка к очагу и очажное место 

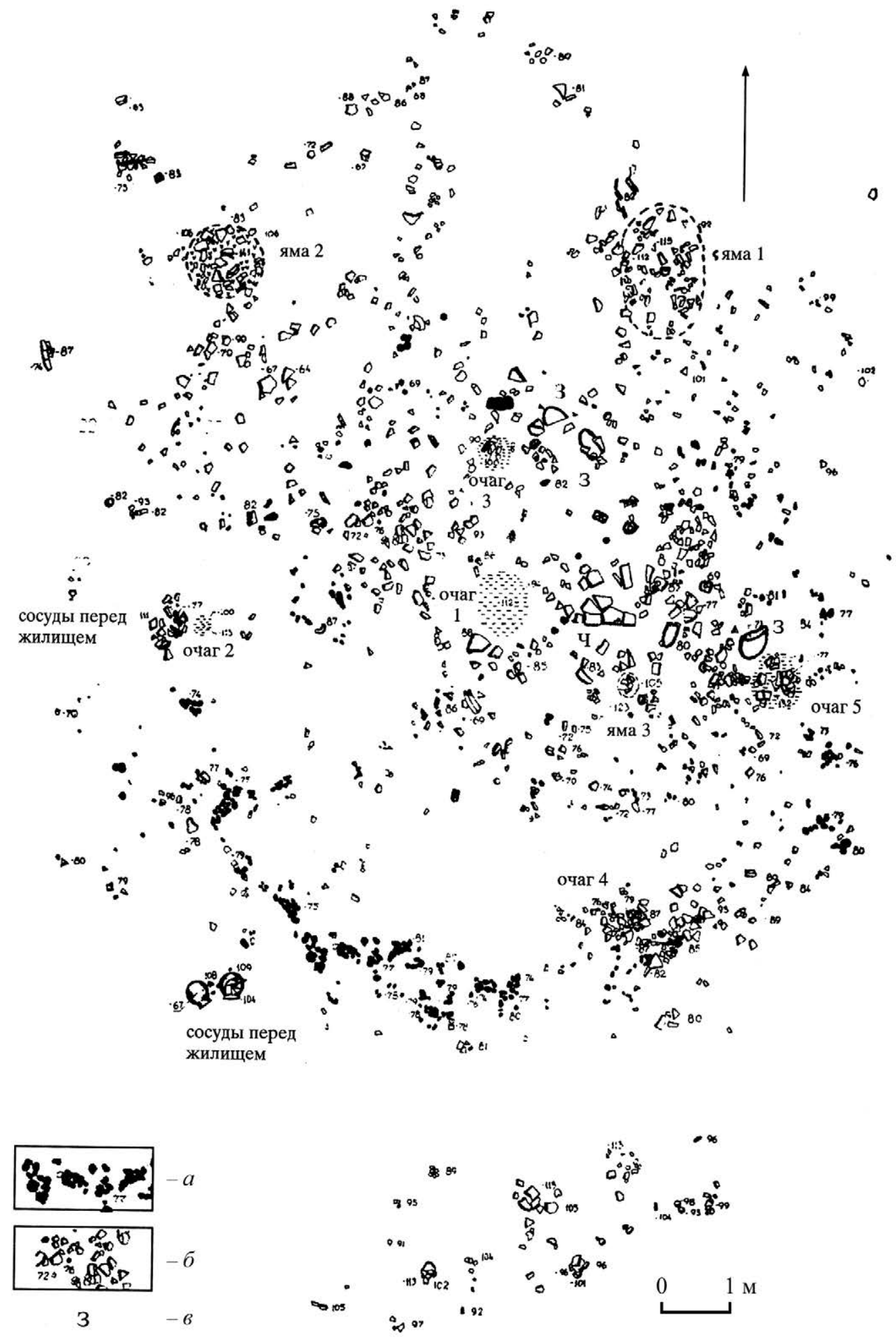

Рис. 111. Постройка 2 пос. Галюгаевское 1

$a$ - горелый турлук, б- черепки, в- зернотерка 


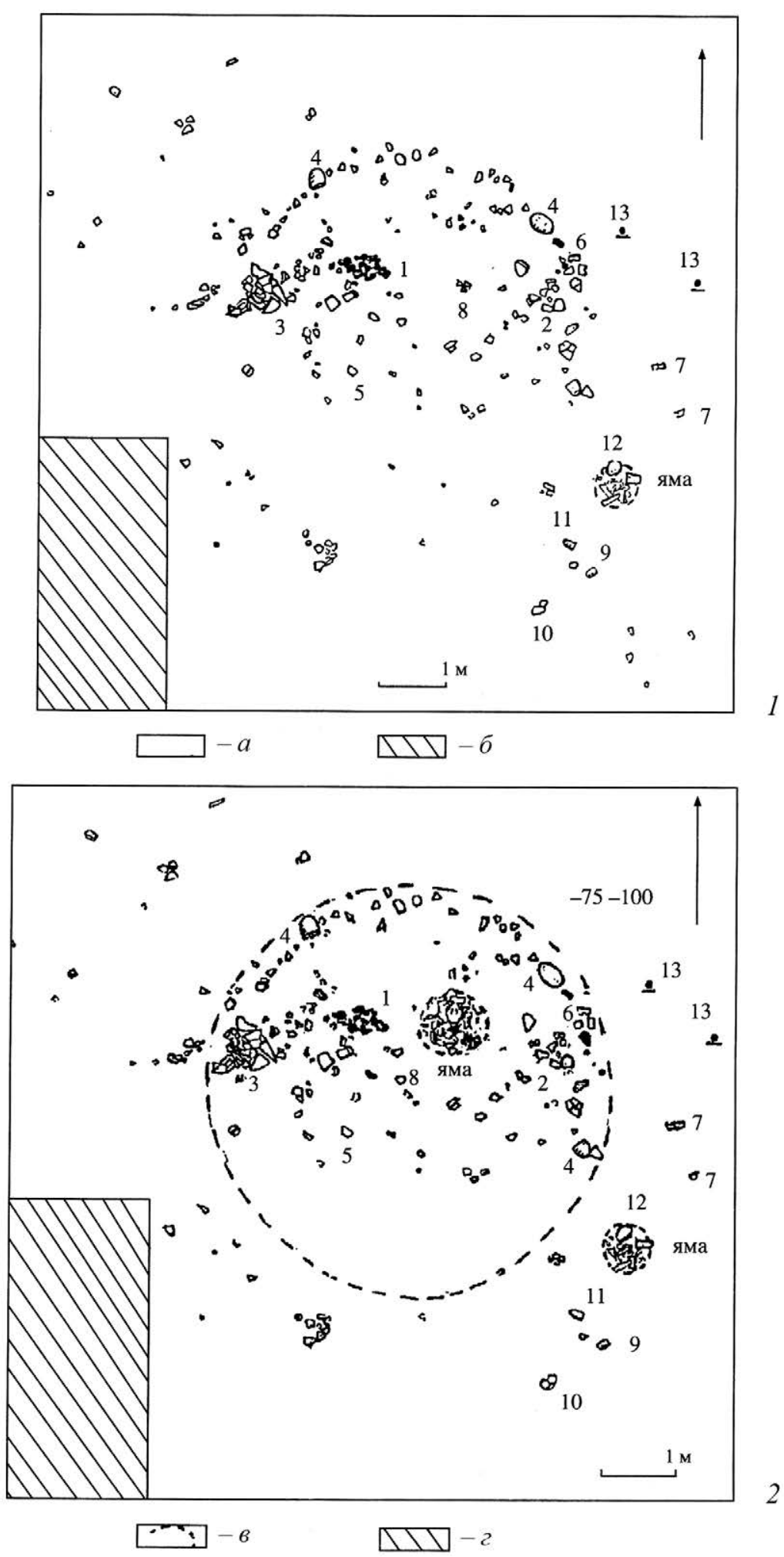

Рис. 112. Постройка 3 пос. Галюгаевское 1

1 - первый уровень расчистки, 2 - второй уровень расчистки

$a$ - зона раскопа, 6,2 - современный перекоп, в- предполагаемый контур строения 


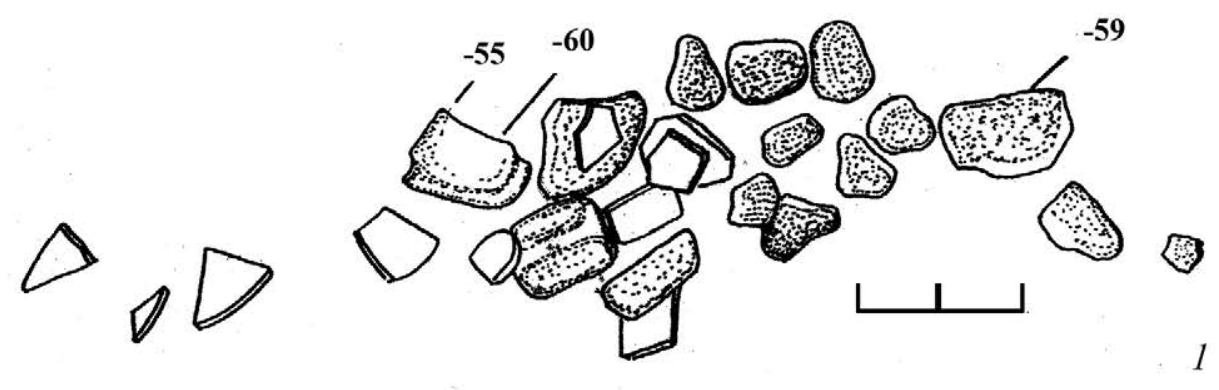

развал турлука

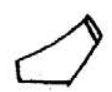

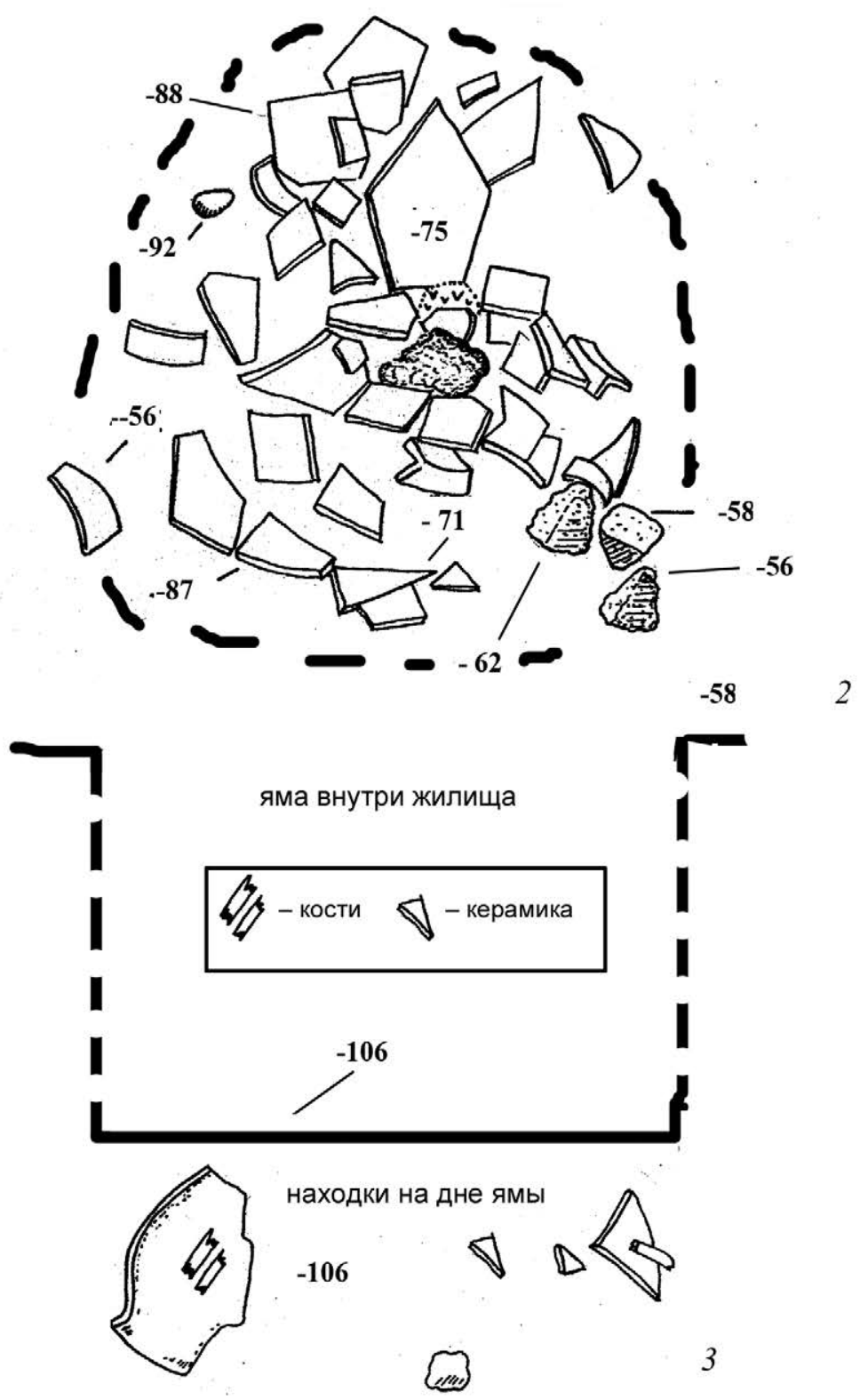

Рис. 113. Постройка 3 пос. Галюгаевское 1

1 - развал турлука, 2 - яма с керамикой, 3- находки на дне ямы 


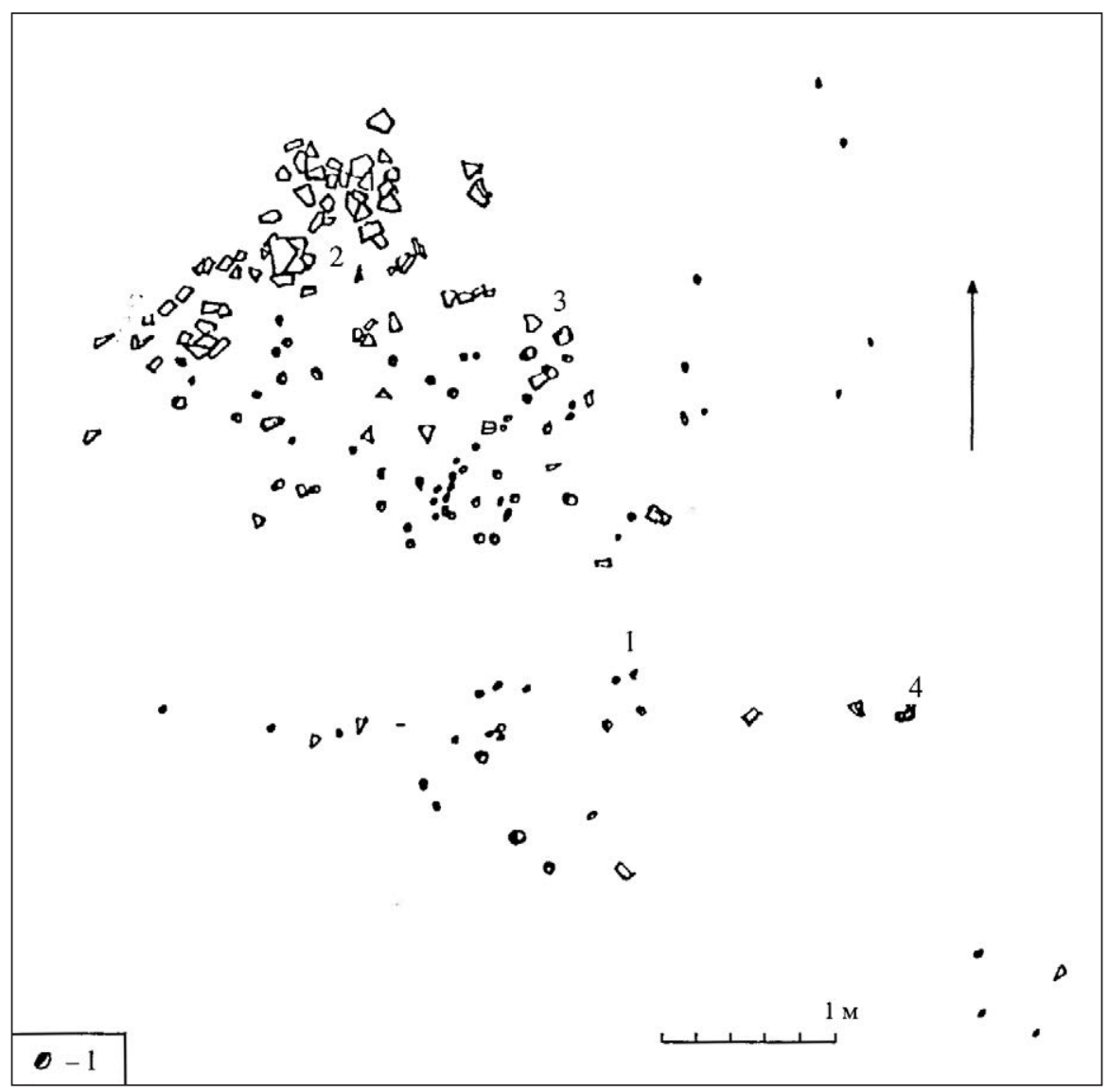

Рис. 114. Поселение Галюгаевское III. Постройка 1 

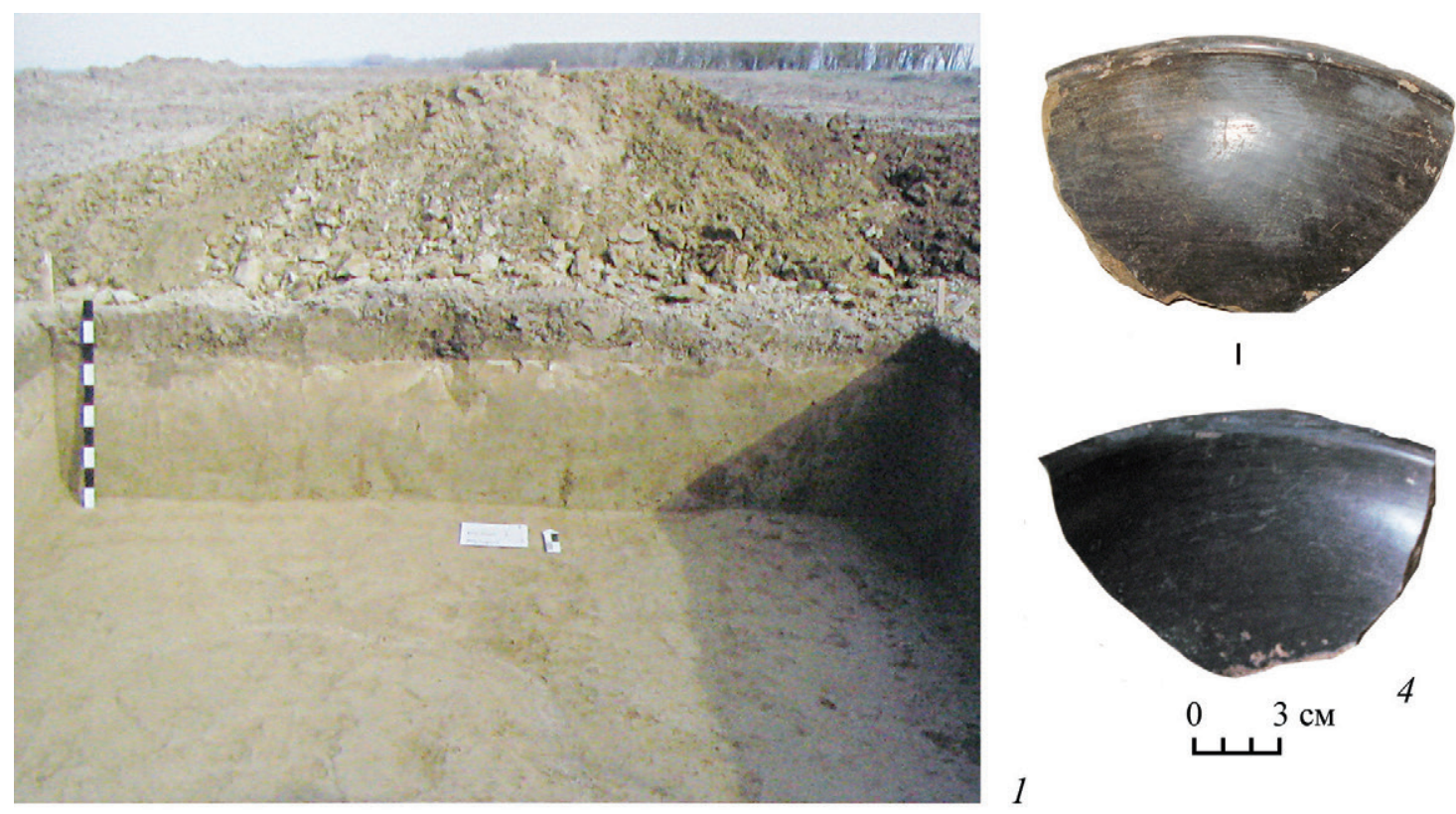

I

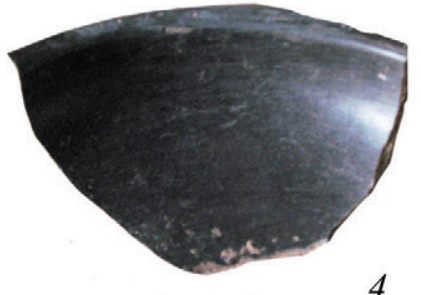

0

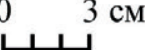

1
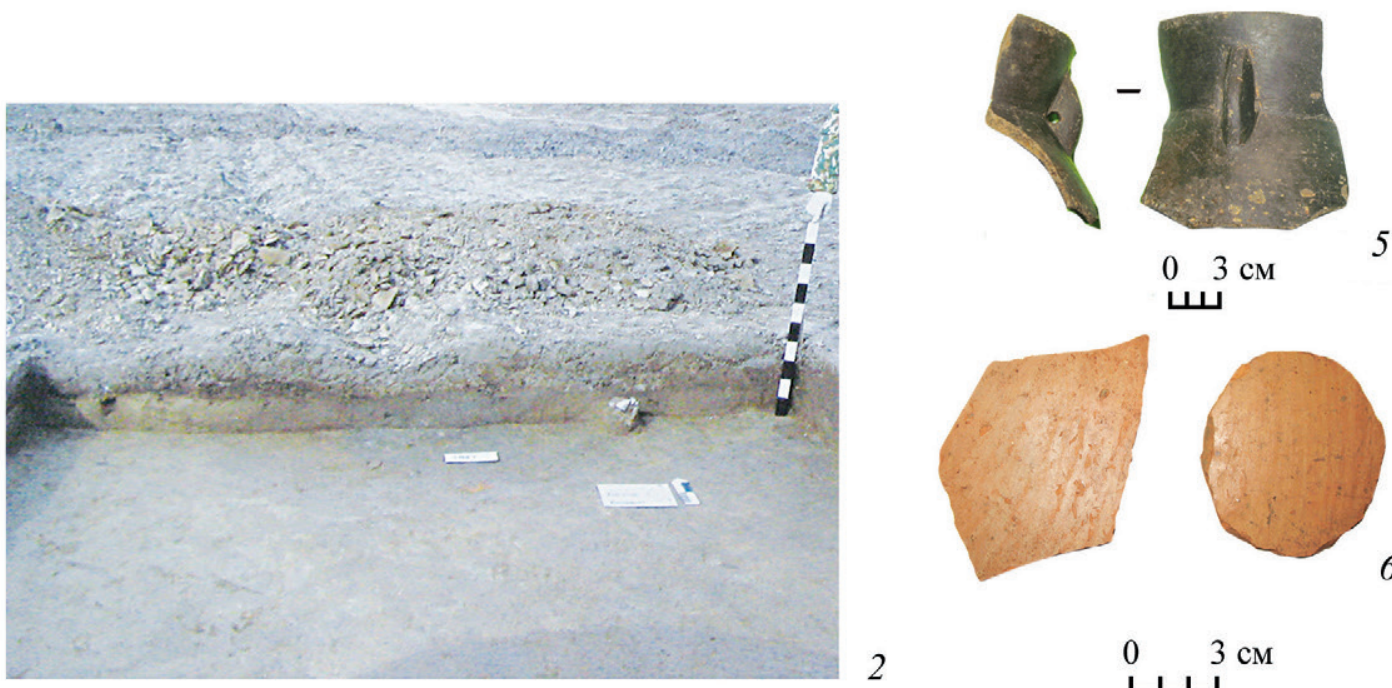

ب

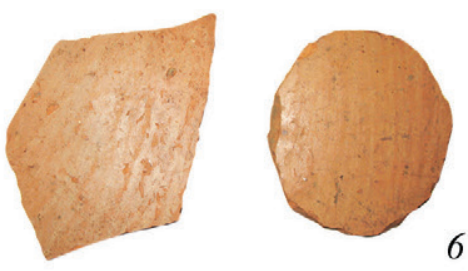

$2 \quad 0 \quad 3 \mathrm{~cm}$
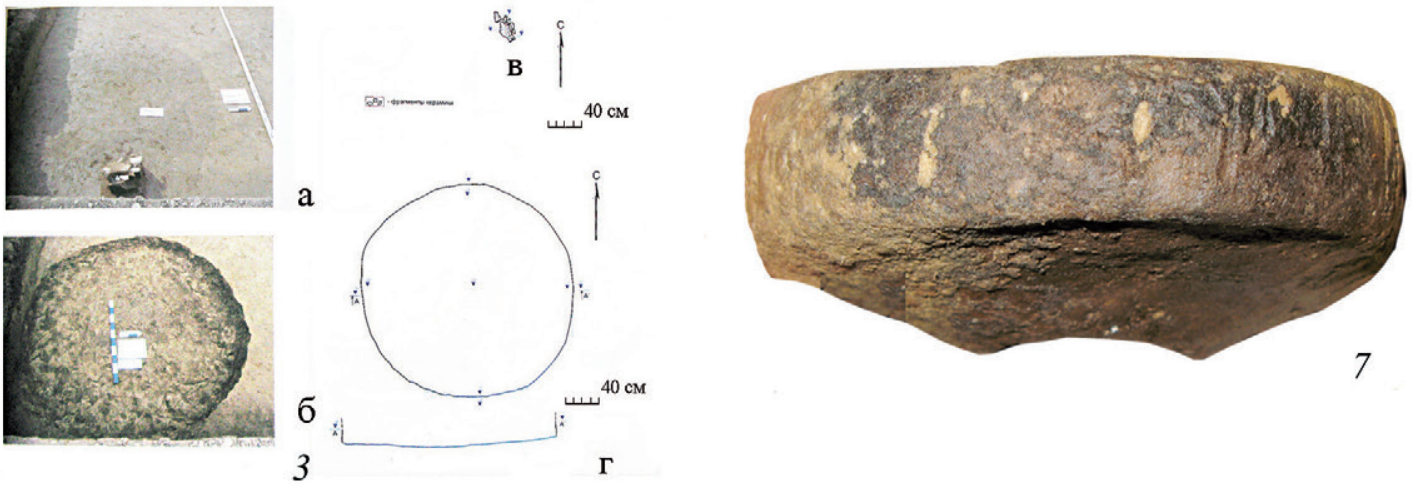

\section{Рис. 115. Поселение Стодеревское и его находки}

1, 2 - северный борт раскопа, 3-яма, диаметр 2,3 м, 4- миска, 5 - сосуд с ушками-ручками. 6- фрагменты керамики, 7- фрагмент приставки к очагу, головка с насечками 1 (по: Березин С.Я) 

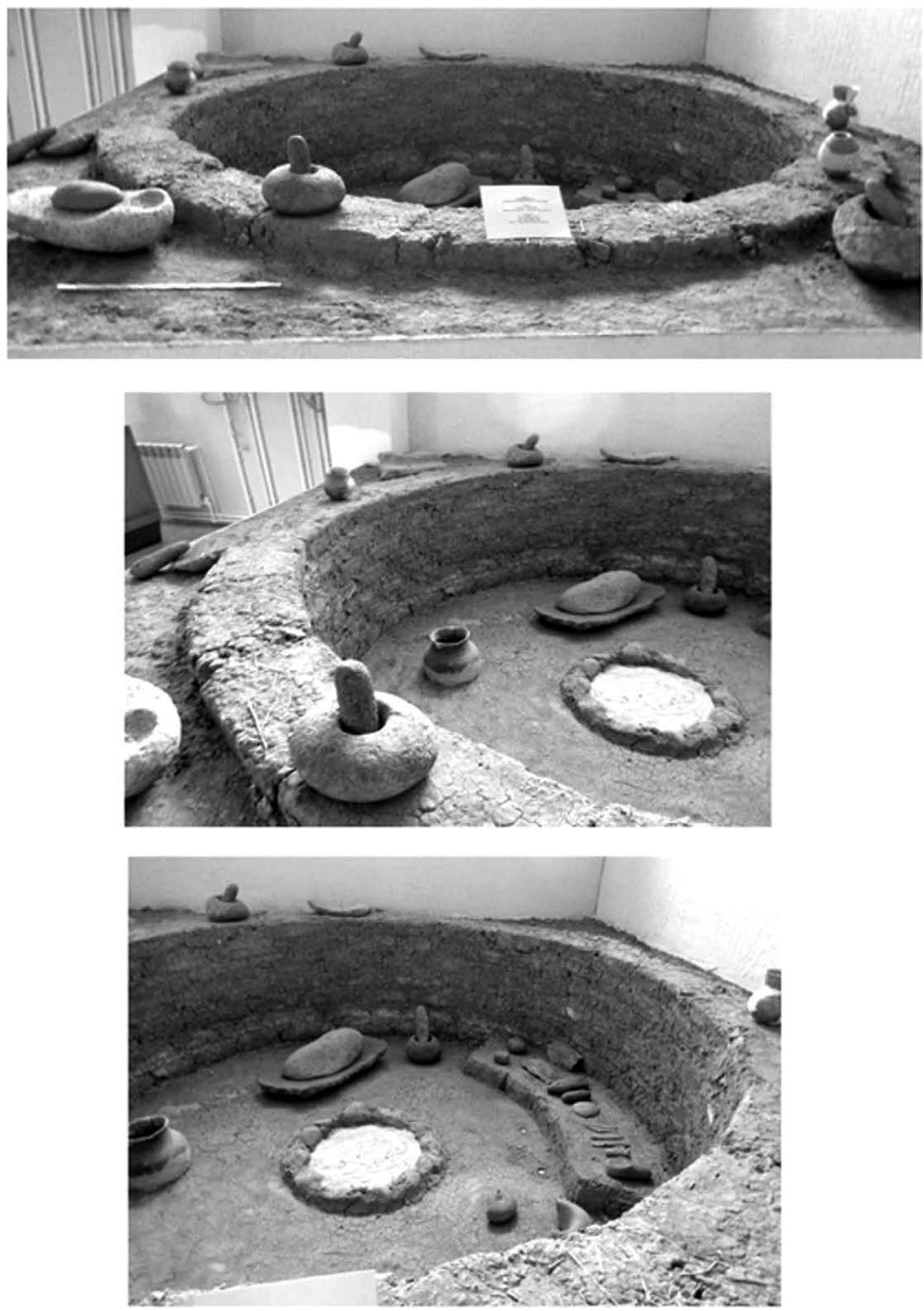

Рис. 116. Жилище на поселении Техут. Раскопки Р. Торосяна. 1966 г. Музей г. Эчмиадзин, Реконструкция А. Тадавосян 

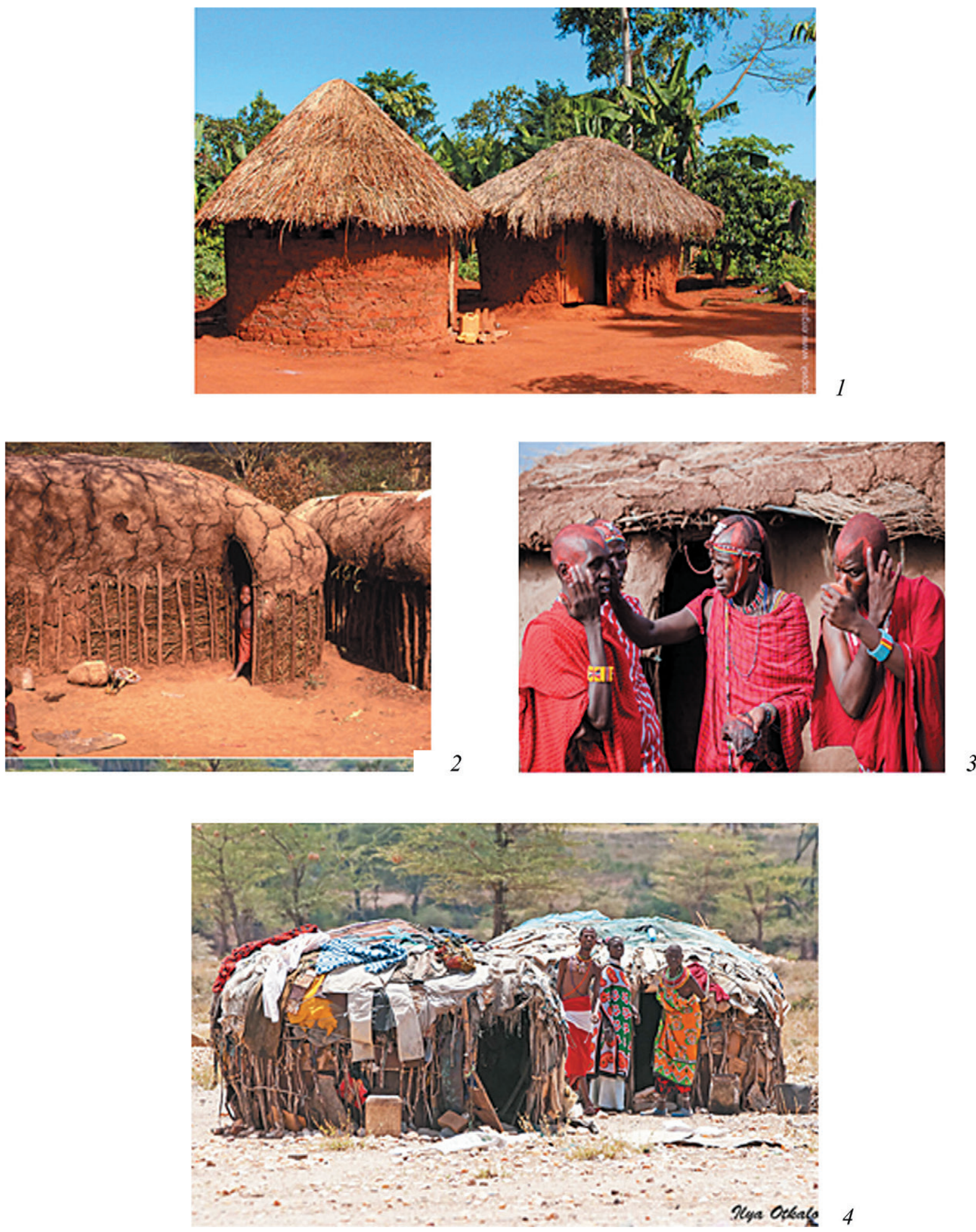

Рис 117. Жилища африканцев Кении и зулусов Наталя, современное время, интернет-ресурс 1 - жилище, обмазанное глиной по периметру, 2 - жилище с обмазанной глиной крышей, 3 - обмазка глиной крыши, 4 - жилища из прутьев и колышков. 


\section{Западный борт раскопа 5}

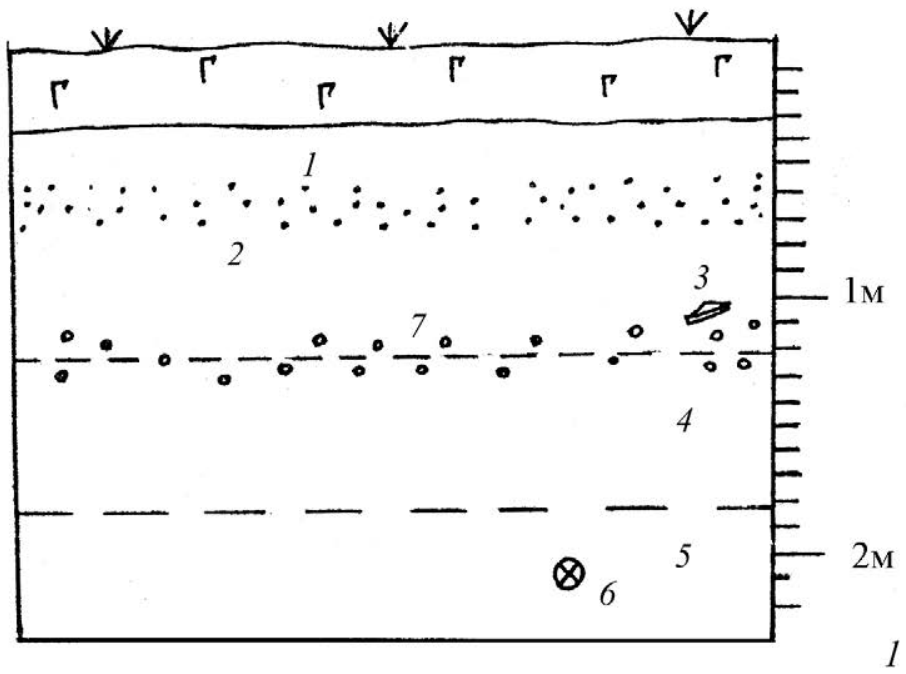

Южный борт раскопа 4

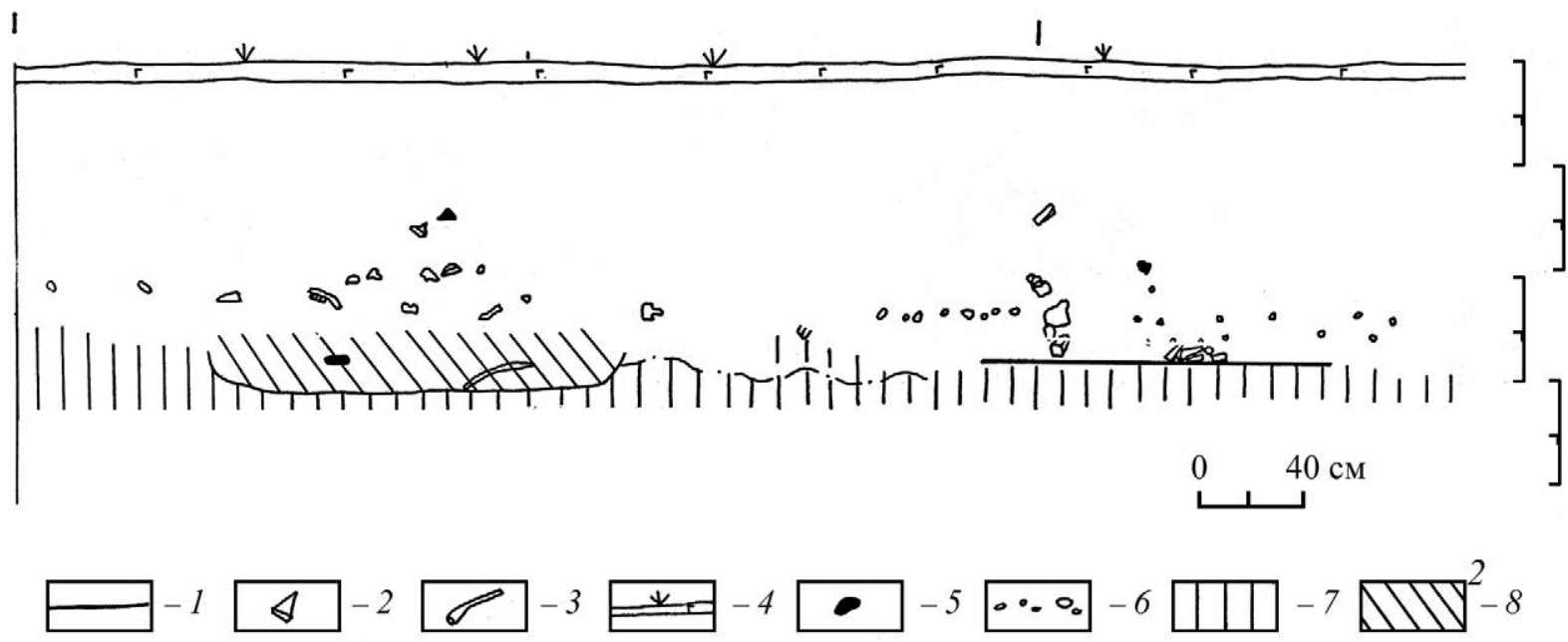

Рис. 118. Карбонаты в слое поселения Галюгаевское 1 (по: Кореневский, 1995)

1 - западный борт раскопа 5

Условные обозначения:

1 - каштановый суглинок, 2 - белесоватые включения, 3 - черепок, найденный на уровне культурного слоя, 4- слой ниже уровня залегания карбонатов, зеленоватый песок материковых отложений, 5 - более жесткий песок материка, 6- норка с черепком, 7- карбонатные включения 2 - южный борт раскопа 4, квадраты 11, 8, 16

Условные обозначения:

1 - сухая площадка, 2 - керамика, 3- кость, 4- дерн, 5 - обожженная глина, 6- карбонаты, 7 - жесткий песок материка, 8 - яма 
Научное издание

\title{
Кореневский Сергей Николаевич
}

Поселение раннего бронзового века Тузла-15 на Тамани

\author{
Дизайн и верстка: В.Б. Степанов \\ Корректура: Л.Н. Казимирова
}

Подписано в печать 07.07.2019. Формат 60×84/8

Усл. печ. л. 23,2. Уч.-изд. л. 20,1

Тираж .... Заказ №

\section{Институт археологии РАН}

117036, Москва, ул. Дмитрия Ульянова, 19

\section{Отпечатано с готового оригинал-макета}

B

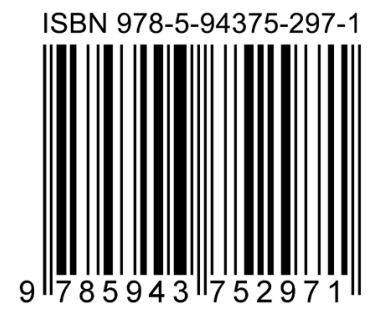

Примечание. На обложке изображены фигурки львов Майкопского кургана, как символы темы о майкопско-новосвободненской общности; раковина-гребешок, найденная на поселении Тузла-15; карта Таманского полуострова с местонахождением поселения Тузла-15. На титульном листе показан каменный топор с майкопского поселения Старотитаровское 
